\author{
UNIVERSIDADE DE SÃO PAULO \\ FACULDADE DE FILOSOFIA, LETRAS E CIÊNCIAS HUMANAS \\ DEPARTAMENTO DE FILOSOFIA \\ PROGRAMA DE PÓS-GRADUAÇÃO EM FILOSOFIA
}

\title{
ESSA MISTURA TERRENA GROSSEIRA: FILOSOFIA E VIDA COMUM EM DAVID HUME
}

Marcos Ribeiro Balieiro

São Paulo 
FACULDADE DE FILOSOFIA, LETRAS E CIÊNCIAS HUMANAS

DEPARTAMENTO DE FILOSOFIA

PROGRAMA DE PÓS-GRADUAÇÃO EM FILOSOFIA

\section{ESSA MISTURA TERRENA GROSSEIRA: FILOSOFIA E VIDA COMUM EM DAVID HUME}

Marcos Ribeiro Balieiro

Tese apresentada ao Programa de Pós-Graduação em Filosofia da Faculdade de Filosofia, Letras e Ciências Humanas da Universidade de São Paulo para a obtenção do título de Doutor em Filosofia, sob a orientação da Profa. Dra. Maria das Graças de Souza.

São Paulo 
COMISSÃO JULGADORA

Presidente da banca

Profa. Dra. Maria das Graças de Souza

Avaliador

Avaliador

Avaliador

Avaliador 


\section{Agradecimentos}

Escrever esta tese foi, sem a menor dúvida, a coisa mais difícil que já fiz, e acredito que devo os agradecimentos mais sinceros a quem quer que tenha dado alguma colaboração para que eu a tenha terminado e mantido, ainda, um mínimo de minha sanidade. Então vejamos...

A Profa. Dra. Maria das Graças de Souza foi a melhor orientadora que eu poderia desejar. Nossas conversas foram sempre muito esclarecedoras e colaboraram imensamente para a solução dos problemas com que me deparei ao longo de minhas pesquisas. Além disso, ela mostrou o tempo todo muito mais paciência do que eu mereceria, inclusive quando teve que ouvir minhas divagações e meus lamentos sobre temas que nada tinham a ver com a filosofia de Hume. Muito, muito obrigado!!! Mesmo!!!

Tenho certeza de que não é fácil ter um filho estudante de filosofia. Meus pais, além de não parecerem horrendamente irritados pelo fato de eu ainda morar com eles aos vinte e nove anos, mostraram-se, ao longo de todo o tempo em que trabalhei no meu doutorado, incondicionalmente compreensivos e amorosos. Sei que isso deve ter exigido um esforço por vezes considerável e espero que, quando a tese estiver impressa, dêem pelo menos uma olhada nos agradecimentos e vejam que sei bem quanto devo a eles!

Minha irmã, por sua vez, merece vários agradecimentos simplesmente por ser a irmã mais legal do mundo!

Certos professores e certos colegas colaboraram, por meio de observações pertinentes sobre meu trabalho, para que eu pudesse chegar às conclusões que exporei neste trabalho, quer em simples conversas, quer em discussões sobre textos em que propus versões mais toscas de pontos que aparecem ao longo desta tese. Entre essas pessoas, eu gostaria de agradecer, em primeiro lugar, os professores Carlos Alberto Ribeiro de Moura e Fernão de Oliveira Salles, que participaram da banca de meu exame de qualificação. Outros professores a quem sou extremamente grato são Márcio Suzuki, Pedro Paulo Pimenta, Lívia Guimarães, Laurent Jaffro, Maria Isabel Limongi, Roberto Bolzani Filho, Caetano Ernesto Plastino, Renato Lessa e Cesar Kiraly. Os colegas com 
quem minha pesquisa tem dívidas enormes são Luís (agora professor da UFSCar), Amaral, Daniel, Bruno, Andrea, Marília, Monica, Andreh, Anice e Bruno Pettersen.

Alguns outros, além de terem dado palpites importantes para a minha pesquisa, merecem ser agradecidos, também, por terem continuado a ser grandes amigos mesmo que a coisa toda de terminar a tese tenha me tornado um tanto distante. Entre essas pessoas, posso destacar Cecília, Thomaz, Patrícia e Isadora.

Outros amigos, ainda que não tenham contribuído em nada para a própria pesquisa, ou mesmo que em alguns casos não saibam muito de filosofia, eu tenho que agradecer simplesmente por terem feito com que eu saísse de casa, conversasse e, à vezes, tomasse umas cervejas, sempre que meus estudos estavam quase me atirando ao estado melancólico que, como todos os humianos sabem, está sempre à espreita. Nesse sentido, mando um "muitíssimo obrigado" para Adriano, Pedro, Daniel, Ivo, Baldini, Guilherme, Vivian, André, Isabela, Guilherme (“Rousseau”), Renata, Dany e Isabela Gaglianone.

Dizem que não é muito sensato incluir a namorada nos agradecimentos de uma tese, já que sempre é possível que um relacionamento termine, não importa quão estável seja, enquanto a tese vai estar sempre lá para quem quiser ver. Ainda assim, não consigo deixar de pensar que a senhorita Ludmila teve que passar seus últimos quatro anos com alguém que, por estar demasiadamente absorto em sua pesquisa, esteve longe de ser um namorado aceitável e, no fim das contas, acho que seria um tanto insensível não agradecer a ela por tudo que ela fez por mim nos últimos anos.

O Ruben merece um "muito obrigado" à parte porque, além ser um grande amigo, e um amigo de longa data, ajudou-me a sobreviver às obrigações burocráticas das quais muitas vezes não temos como escapar.

Por falar em obrigações burocráticas, eu também não teria sobrevivido a elas sem a ajuda de todo o pessoal da secretaria. Então, nada mais justo que agradecer também à Marie, à Maria Helena, à Verônica, à Geni, à Roseli, à Luciana e à Mariana. Aproveito para pedir desculpas pelas vezes em que minhas preocupações se transformaram em aborrecimentos para elas.

Last but not least, agradeço ao CNPq pela bolsa que permitiu que eu me dedicasse, integralmente, ao longo de todo o doutorado, à minha pesquisa. Sei que esse 
agradecimento é obrigatório para todos os bolsistas, mas quero assegurar que, no meu caso, ele é bastante sincero. Honestamente, eu não sei se teria conseguido terminar esta tese se tivesse que dividir meu tempo entre ela e outro trabalho. 


\section{SUMÁRIO}

Agradecimentos 3

$\begin{array}{ll}\text { RESUMO } & 7\end{array}$

$\begin{array}{lc}\text { AbSTRACT } & 8\end{array}$

$\begin{array}{ll}\text { INTRODUÇÃO } & 10\end{array}$

$\begin{array}{ll}\text { PARTE I } & 17\end{array}$

Capítulo I - Que ilusões? 18

A análise cética dos sentidos 22

Filosofia antiga, filosofia moderna e falsa filosofia 41

A identidade pessoal e as filosofias do sujeito

Capítulo II - Que malefícios? 63

A falsa filosofia e as morais do amor próprio 67

Uma história de corrupção $\quad 89$

A evolução do conceito de falsa filosofia 100

$\begin{array}{ll}\text { PARTE II } & 103\end{array}$

Capítulo III - Que conhecimento? 104

$\begin{array}{ll}\text { A experiência como salvação } & 105\end{array}$

$\begin{array}{lr}\text { Conhecimento, experiência e natureza } & 120\end{array}$

Ceticismo, naturalismo, realismo, vida comum 141

$\begin{array}{lr}\text { A religião como caso } & 150\end{array}$

$\begin{array}{ll}\text { Capítulo IV } & 154\end{array}$

O pintor e o anatomista 160

A experiência como participação e a correção do senso comum 179

O papel da história 195

$\begin{array}{ll}\text { Conclusão } & 204\end{array}$

$\begin{array}{ll}\text { Bibliografia } & 214\end{array}$ 


\section{RESUMO}

BALIEIRO, M., Essa mistura terrena grosseira: filosofia e vida comum em David Hume. 2009. 222 f. Tese (Doutorado) - Faculdade de Filosofia, Letras e Ciências Humanas. Departamento de Filosofia, Universidade de São Paulo, São Paulo, 2009.

Ainda que muitos trabalhos tenham sido escritos sobre a filosofia de David Hume, é bastante raro vermos comentários sobre o que seria, para ele, a própria filosofia. Na maior parte das vezes, os intérpretes da obra desse filósofo limitam a caracterizá-lo como cético, naturalista, realista, sentimentalista, entre outras categorias. Entretanto, falta-lhes, comumente, uma preocupação real em julgar as teses de Hume à luz daquilo que poderia ser considerado a sua concepção de filosofia.

O que pretendemos com este trabalho é justamente indicar uma forma de lidar com os textos de Hume que permita iniciar uma discussão aprofundada da concepção que ele próprio tinha da atividade filosófica. Para isso, trataremos principalmente dos textos em que o autor discute especificamente esse tema, além de recorrer, quando isso se mostrar necessário, a outros aspectos da filosofia humiana. O resultado será uma leitura em que a filosofia é considerada como bastante próxima da vida comum, já que Hume se esforça consideravelmente para representar o filósofo um ser essencialmente social, cujas investigações são pautadas por uma experiência que ele compartilha com o vulgo. Além disso, veremos que, nos textos posteriores ao Tratado da natureza humana, Hume considerou a filosofia não como algo que deveria ficar restrito às universidades, mas como uma ferramenta poderosa de formação moral para o homem comum.

Palavras-chave: Hume, filosofia escocesa, luzes britânicas, filosofia, vida comum. 


\begin{abstract}
BALIEIRO, M., This gross earthy mixture: Hume on philosophy and common life. 2009. 222 p. Thesis (Doctoral). Faculdade de Filosofia, Letras e Ciências Humanas. Departamento de Filosofia, Universidade de São Paulo, São Paulo, 2009.

Even if many works have discussed the philosophy of David Hume, not many of them have discussed what might consider philosophy itself to be. Most of the times, interpreters of his works don't go further than characterizing him as skeptic, naturalist, realist, sentimentalist, among other categories. However, they commonly lack a real concern to judge Hume's theses in the light of what might be thought of as his conception of philosophy.

What we intend is exactly to point out a way of dealing with Hume's texts which may allow an in-depth discussion of his conception of the philosophical activity. Therefore, we shall deal mainly with texts in which the author discusses this theme specifically, besides recurring, whenever it proves necessary, to other aspects of his philosophy. The result shall be a reading in which philosophy is considered as being quite close to common life, since Hume makes a considerable effort to present the philosopher as an essentially social being, whose investigations are backed by an experience which he shares with the vulgar. Besides, we shall observe that, in texts posterior to the Treatise of human nature, Hume considered philosophy not as something which should be restricted to the universities, but as a powerful tool for the moral formation of the common man.
\end{abstract}

Key words: Hume, Scottish philosophy, British enlightenment, philosophy, common life. 
“(...) aquele que quebra uma coisa para descobrir o que ela é deixou o caminho da sabedoria.”

J. R. R. Tolkien, O Senhor dos Aneis: A Sociedade do Anel 


\section{INTRODUÇÃO}

De maneira geral, podemos dizer que, em filosofia, o trabalho dos comentadores consiste, basicamente, em estabelecer a interpretação mais consistente de alguns conceitos, tal como eles se dão na obra do autor a que eles tiverem escolhido dedicar

seus estudos. É claro que, em alguns casos, alguém parte de comentários sobre a obra de um filósofo em particular para afirmações que apontam para algo como uma filosofia própria, mas, via de regra, aquele que chamamos historiador da filosofia trata, antes de qualquer coisa, de verificar de que modo um dado pensador via este ou aquele conceito. Ainda assim, espera-se do bom comentador que ele seja capaz de apontar problemas que podem não ter sido plenamente resolvidos pelo autor cujo texto ele disseca e, mais do que isso, é perfeitamente possível que um comentador simplesmente manifeste sua insatisfação com certo aspecto da obra de um dado filósofo. Espera-se até mesmo que seja capaz, ao menos em alguns casos, de identificar, em meio a escritos cunhados pela pena de um filósofo, aquelas afirmações que talvez não sejam filosóficas ou que, em alguns casos, talvez sejam "menos filosóficas” do que outras defendidas por seu "objeto de estudo”.

Quando pensamos na obra de David Hume, essas considerações, por mais óbvias que possam parecer, dão margem a reflexões curiosas, já que boa parte daqueles que se dedicaram a ela, além de realizarem comentários importantes, parecem ter sido influenciados por ela quando formularam suas próprias teses. Ainda que, a rigor, a filosofia humiana não tenha tido uma posteridade no sentido da fundação de uma “escola”, certamente foi importante para pensadores como Deleuze, Hare, Husserl e os partidários do chamado Círculo de Viena, entre outros. É claro que a importância da obra de Hume não é a mesma para todos eles, nem do ponto de vista do tamanho do impacto que exerceu, nem do ponto de vista da natureza deste, mas é certo que eles devem algo ao filósofo escocês. E isso, evidentemente, não teria sido possível se não tivesse visto em sua obra algo que valesse apena aproveitar ou criticar.

Além disso, não são apenas aqueles interessados em desenvolver filosofias originais que julgam aspectos da obra de Hume como “mais ou menos filosóficos”. Para ficar em um exemplo, é comum, entre os comentadores da epistemologia desenvolvida por ele, desferir contra a doutrina do hábito a acusação de psicologismo. Até aí, nada de 
anormal. Comentadores de outros filósofos certamente realizam acusações parelhas ao esbarrar, em seus estudos, em afirmações que consideram menos filosóficas que outras. Ao realizarem críticas como essas, tais comentadores permitem entrever uma concepção de filosofia. No caso dos comentadores de Hume a que acabamos de nos referir, aqueles que o acusam de psicologismo o fazem não apenas porque detectam, na epistemologia humiana, essa característica, mas também porque acreditam que a filosofia é algo que tem certas características bem determinadas e, definitivamente, o psicologismo não está entre elas, seja ele o que for. Desse modo, é fácil concluirmos que não apenas filósofos tributários de Hume, mas também aqueles que se dedicaram exclusivamente a esclarecer aspectos importantes de sua obra tinham em mente uma ideia do que a filosofia, em sua forma verdadeira, deve ser. Isso nos permitiria partir para uma discussão do modo como filosofia e história da filosofia se relacionam, mas esse tema certamente escapa, atualmente, à nossa competência. Além disso, este trabalho é uma tese sobre Hume e, mesmo que estivéssemos habilitados a desenvolver de maneira apropriada uma discussão sobre os papéis de filósofos, comentadores e o que quer que esteja no meio termo entre eles, essa questão faria com que nos desviássemos excessivamente do tema que nos interessa aqui.

Se mencionamos essa discussão, foi para mostrar que praticamente todo texto filosófico, seja ele escrito por um comentador ou por um pensador original, defonta-se, de algum modo, com o problema de compreender o que é a filosofia. Esse pode ser um tema para o qual muitos comentadores apresentam soluções quase instintivas, simplesmente pressupondo que esta afirmação é filosófica enquanto aquela outra não é. Do mesmo modo, muitos filósofos parecem não ter atentado para o problema da própria delimitação do que é a atividade filosófica, escolhendo temas por conta de suas inclinações pessoais ou do que a época lhes ditava. Ainda assim, em qualquer discussão filosófica está incluído, também, o debate sobre a natureza da própria filosofia e, nesse sentido, parece que os comentadores, bem como os filósofos que interpretam outros filósofos, têm uma atitude um tanto estranha quando, em um dado momento, julgam a "filosoficidade" de certas teses dos autores que estudam segundo uma concepção de filosofia que não é a deles. Talvez ao menos os comentadores, portanto, devam prestar alguma atenção àquilo que "seu objeto de estudo” diz a respeito.

É óbvio que essa não é uma questão simples. Para respondê-la, não basta que atentemos àquilo que os pensadores de uma determinada época consideravam as 
atribuições normais dos filósofos. Também não basta, quando tratamos de um autor em particular, que consigamos explicar de maneira satisfatória os pontos mais importantes de sua doutrina. Uma certa concepção de razão, por exemplo, não é, por si só, uma definição de filosofia. A determinação de um objeto de estudo também não. Desse modo, ao nos voltarmos especificamente para a filosofia de David Hume, explicar a teoria do hábito não é explicar a concepção da atividade filosófica defendida por esse autor, ainda que, como veremos, essas duas questões estejam relacionadas. Do mesmo modo, afirmar que Hume é um cético é fazer uma afirmação que, em alguma medida, está correta, mas não é explicar satisfatoriamente o que é, para ele, a filosofia. Afirmar, como fizeram tantos comentadores da filosofia humiana de maneira irritantemente redundante, que a filosofia é, para esse pensador, a ciência do homem, igualmente, é dizer algo correto, mas algo que não dá conta plenamente daquilo que Hume considerava que a atividade filosófica deveria ser. Para ele, como para vários autores, a resposta a essa pergunta era muito mais difícil e, de certa maneira, era, também, indissociável de respostas para questionamentos como “o que sou eu?”, “qual o melhor meio para conhecermos o mundo que nos cerca?”, “o que está ao alcance de nosso conhecimento, e o que escapa dele?”, entre outras. É certo que essas perguntas seriam consideradas por Hume como questões filosóficas e, além disso, é certo que, uma vez que as tivesse respondido, nosso autor consideraria que seu ofício enquanto filósofo o obrigaria a realizar outras: "de que modo a filosofia interfere no conhecimento dos mais variados temas?”, “qual a utilidade da filosofia, e qual poderia ser?”, “qual a relação disso que chamo filosofia com o mundo dos que permanecem alheios a ela?”. No fim das contas, portanto, determinar o que é a filosofia é algo que, aparentemente, pode ser algo impossível para qualquer comentador da obra de Hume que não esteja atento para o modo como essa questão se desenvolve nos escritos desse filósofo sobre os mais diversos temas, já que a determinação do que é essa forma de conhecimento denominada filosofia passa por considerar as suas manifestações que se ocupam das ciências, da moral, da política, da estética, além de depender, sem a menor dúvida, de uma compreensão adequada do modo como a atividade filosófica se relaciona com o homem comum.

Não pretendemos, ao longo deste trabalho, dar uma resposta verdadeiramente exaustiva à questão do que é, para Hume, a filosofia. Um empreendimento como esse tomaria mais tempo do que permitiriam os prazos de qualquer departamento e, além 
disso, resultariam em um trabalho extenso o suficiente para fazer cair no sono qualquer banca, por mais boa vontade que ela tivesse ${ }^{1}$. Ainda assim, tentaremos verificar qual é a concepção de filosofia que nosso autor considera que se dá a partir de sua teoria do conhecimento e, é claro, observar em que medida seus escritos sobre outros temas permitem acrescentar algo a essa concepção. Além disso, veremos de que modo se dá, para Hume, a relação entre filosofia e senso comum. Esse é um tema interessante não apenas por estar intimamente relacionado à maneira como nosso filósofo via o próprio conhecimento, mas também porque a relação entre filosofia e senso comum é, para ele, algo que aparece imediatamente quando tratamos daquilo que a filosofia é quando vista enquanto atividade.

Para esses propósitos, valer-nos-emos principalmente dos vários textos em que Hume considera a própria natureza da filosofia. Ora, nem todos os filósofos explicitam o modo como viram esse problema e, se nosso autor se preocupou com ele de maneira tão perceptível, isso é algo que não podemos ignorar. Ainda assim, será preciso que recorramos, em certos momentos, a trabalhos em que a preocupação central de Hume não é a própria filosofia. É o que ocorre, por exemplo, na parte de nosso terceiro capítulo em que lidamos com a epistemologia humiana. Em parte, é também o caso de textos que podem ser lidos tanto como trabalhos sobre outros temas quanto como considerações sobre a própria filosofia. É bem esse o teor, por exemplo, da seção do Tratado da natureza humana em que Hume discute a questão da identidade pessoal. É o caso, também, do “Apêndice 2” da Investigação sobre os princípios da moral, dos Diálogos sobre a religião natural e da História natural da religião. Nesses casos de

\footnotetext{
${ }^{1}$ Isso não implica uma crença de que os comentadores estão livres de ter que lidar com essa questão. Não recomendamos, é claro, que todos eles, antes de se dedicar a outros temas, resolvam completamente esse primeiro problema, o que acarretaria também a eles problemas com prazos e, principalmente, a impossibilidade de virem a tratar, um dia, de outras questões, que talvez despertem neles maior interesse. Apenas consideramos que seria interessante que eles prestassem mais atenção ao fato de qualquer filósofo ter, além das teses explícitas em seus trabalhos, uma concepção de filosofia que, por vezes, pode não ter sido mostrada com todas as letras, mas sem dúvida influencia o tratamento que um autor confere aos temas a que se dedica. Nesse sentido, podemos elogiar, por exemplo, o reconhecimento do tema por parte de Don Garrett, na introdução do livro Cognition and Commitment in Hume’s Philosophy. Não se trata, aqui, necessariamente de endossar as posições de Garret sobre a concepção humiana de filosofia, mas de louvar seu esforço por levar em consideração de forma explícita, em um livro sobre outro tema, a importância de estar consciente dessa questão.
} 
“adequação parcial” ao tema da verdadeira filosofia e de sua relação com o senso comum, tentamos ressaltar os aspectos desses textos que faziam da própria filosofia uma preocupação essencial. Quanto aos textos em que o que estava em discussão não parecia ser a natureza da filosofia, tentamos usá-los como apoio para as teses que víamos nos outros. Talvez a única grande exceção seja a análise da epistemologia humiana que ocorre no capítulo 3, ainda que ela mesma possa ser vista, no fim das contas, como uma grande estrutura de apoio da qual não foi possível abrir mão.

Antes de passar ao tratamento daquilo que Hume considerava que a filosofia é, entretanto, buscaremos explicar o que ele considerava que ela não é. Isso nos ocupará ao longo de toda a primeira parte, ou seja, no primeiro e no segundo capítulos. No primeiro, discutiremos o modo como nosso autor desconstroi doutrinas como a das qualidades ocultas e a da dupla existência, o que nos oferecerá um primeiro contato com características essenciais daquilo que é, para Hume, a boa filosofia, como o recurso constante à experiência e o assentimento a certas ficções que são irresistivelmente impostas pela natureza. Além disso, mostraremos como a posição defendida por Hume acerca da identidade pessoal pode ser vista não apenas como uma forma de discorrer sobre esse tema, mas também o coroamento de uma crítica às filosofias de matriz cartesiana que, além de empregarem um sentido de razão que, como veremos posteriormente, nosso filósofo não mede esforços para recusar, depende de uma certa noção de eu, de modo que criticá-la é não apenas falar sobre a própria identidade pessoal, mas negar a possibilidade de um certo tipo de filosofia. É praticamente desnecessário dizermos que esse capítulo será pautado pela análise de algumas seções da Parte 4 do Livro 1 do Tratado da natureza humana.

No segundo capítulo, veremos que a falsa filosofia, já caracterizada pelo distanciamento da experiência e da conseqüente adesão a princípios que são aceitos por estarem de acordo com inclinações particulares daqueles que os defendem, pode exercer impacto considerável sobre as teorias morais e, mais do que isso, pode engendrar problemas reais nas vidas não apenas daqueles que aceitam essas filosofias corrompidas, mas, também, de homens que nada têm de filósofos. Essas considerações serão apoiadas principalmente na análise das filosofias do amor próprio realizada no Apêndice 2 da Investigação sobre os princípios da moral e na crítica das religiões populares que Hume empreende na História natural da religião. 
A segunda parte de nossa tese tratará, enfim, daquilo que consideramos ser ao menos parte da concepção humiana da verdadeira filosofia. No Capítulo 3, realizamos uma leitura bastante detalhada da Conclusão do Livro 1 do Tratado, mostrando, em seguida, de que modo a concepção de filosofia mostrada nesse texto está apoiada nas teses epistemológicas defendidas por Hume. Para isso, ver-nos-emos obrigados a tomar parte no "new Hume” debate, já que acreditamos que isso nos oferecerá uma percepção acurada do modo como o ceticismo se apresenta na obra de nosso autor, o que se mostrará essencial para que compreendamos os motivos que o levaram a fazer do filósofo um ser que assente às suas propensões, agindo sempre de acordo com o que lhe ordena a natureza. Isso será importante, também, para que possamos determinar o caráter eminentemente social do filósofo e o modo como sua razão e seus pontos de partida são, e devem ser, os mesmos do homem comum. Evidentemente, o que nos interessa não é tanto fazer uma exposição exaustiva da epistemologia humiana, mas observar o que ela nos permite dizer sobre a concepção que seu autor teria da própria atividade filosófica. Encerraremos esse capítulo com uma discussão bastante breve sobre os Diálogos sobre a religião natural, com a qual buscaremos reforçar o papel que Hume atribui à experiência na filosofia, além de ilustrar, mais uma vez, o que ele considera que acontece quando nos distanciamos demais do mundo percebido que o filósofo compartilha com os outros homens.

No quarto capítulo, passaremos de maneira bastante casual pela questão de como Newton poderia ter inspirado Hume, chegando, então, ao problema de como nosso autor, partindo de uma ciência experimental do homem que terminaria por humanizar o filósofo ao comunicar a ele parte da "mistura grosseira terrena” que constitui as pessoas comuns, passou a ser também, nos escritos posteriores ao Tratado, alguém que buscou tornar sua filosofia atraente também para aqueles que não eram filósofos profissionais. Isso teria ocorrido porque, em seus escritos de maturidade, nosso autor teria percebido ser possível conciliar a filosofia fácil, que busca incitar os homens à virtude, e a abstrusa, que procura, a partir de raciocínios extensos e complicados, explicar os princípios que regem o homem, tais como se apresentam à razão. Essa conciliação, como se sabe, era considerada impossível por Hume quando ele escreveu o Tratado. Essas mudanças serão tornadas evidentes com uma análise da Seção 1 da Investigação sobre o entendimento humano, que compararemos aos parágrafos finais do Tratado e a uma carta de Hume a Hutcheson. Depois de tratar dessa questão, buscaremos mostrar o 
que a aproximação com o homem comum permite dizer sobre o próprio caráter da experiência. Isso nos levará a fazer algumas observações sobre o caráter dos testemunhos na filosofia humiana (e, portanto, mais algumas considerações sobre o fenômeno religioso) e a tratar da relação entre a verdadeira filosofia e a história. Podemos adiantar que, no que diz respeito a este último tema, a história é vista por ele como importante porque permite algo como a expansão da experiência, além de abrir portas importantes para um filósofo que não pretendia que seus escritos ficassem acorrentados aos muros das universidades.

Na Conclusão, além de uma brevíssima retomada do que foi apresentado ao longo do restante deste trabalho, mostraremos que boa parte da preocupação de Hume em tornar a filosofia acessível ao homem comum provém da consideração de que a felicidade é um tema filosófico essencial. Nesse sentido, a realização da "filosofia fácil” ganha importância considerável. Tentaremos mostrar que, ao buscar afetar o homem comum, portanto, a filosofia deverá, ao menos em parte dos casos, operar do mesmo modo que qualquer obra literária, apelando às paixões. Não realizaremos um tratamento detalhado do modo como isso ocorre porque isso exigiria uma análise bastante longa da teoria humiana das paixões que, além de ser inviável, descaracterizaria o presente trabalho, já que uma análise desse tipo não teria uma relação tão íntima com os problemas que já estavam dados nos capítulos anteriores e, desse modo, poderia parecer estranho o recurso a mais uma gigantesca estrutura de apoio. De qualquer forma, esse aspecto da concepção humiana de filosofia certamente nos parece bastante interessante e, portanto, deve merecer atenção considerável em nossas pesquisas futuras.

Feita esta breve apresentação, convém que passemos, sem mais delongas, aos tópicos a que acabamos de nos referir. Esperamos que a leitura do texto que se segue seja tão interessante quanto foi escrevê-lo, mas que seja bem mais fácil e menos desgastante. 
PARTe I 


\section{CAPÍTULO I}

\section{QUE ILUSÕES?}

Como havíamos dito na Introdução, trataremos, neste primeiro capítulo, do modo como Hume começa, na Parte 4 do Livro 1 de seu Tratado da Natureza Humana, a especificar as características do que é, para ele, a falsa filosofia. Mais especificamente, nosso objetivo será mostrar de que modo uma parte nada desprezível dos textos presentes nessa parte da obra de estreia de nosso autor pode colaborar para que sejam desvelados os princípios da natureza humana que Hume considera responsáveis pelo surgimento da filosofia em suas formas falsas, bem como pelo fato de que ela acaba conseguindo para si um grau bastante alto de credibilidade. Estamos conscientes de que essa análise não nos permitirá descobrir todas as características do que Hume chama de falsa filosofia. De qualquer maneira, além de nos voltarmos para os textos em que Hume parece efetivamente introduzir o problema, faremos, neste momento, análises que certamente se mostrarão de grande valia não apenas enquanto buscarmos compreender a concepção humiana das formas falsas da atividade filosófica, mas, também, em um momento posterior, quando buscarmos descobrir o que nosso autor considera que a filosofia deve ser.

Isso posto, é conveniente observarmos que a Parte 4 do Livro 1 do Tratado da Natureza Humana tem sido sistematicamente negligenciada por boa parte dos comentadores, a não ser pela seção 6, que trata da identidade pessoal, e pela “Conclusão", que é habitualmente lembrada por defensores tanto do "Hume cético" quanto pelos do "Hume naturalista" como um texto que corrobora suas posições. É claro que há exceções ${ }^{2}$, mas, de maneira geral, podemos dizer que a Parte 4 do Livro 1

\footnotetext{
${ }^{2}$ A mais notável delas talvez seja Donald Livingston, que, em seu Philosophical Melancholy and Delirium, defende que o Tratado deveria ser lido justamente à luz da Parte 4 do Livro 1, já que essa é a parte de sua obra de estréia em que Hume tece suas considerações sobre o que é a própria filosofia. Curiosamente, Livingston parece um tanto perdido justamente quanto à seção 6. Segundo esse comentador, ela parece, ao menos aparentemente, não enfatizar um “subtexto” que trate daquilo que a
} 
vem sendo relegada a segundo plano. Talvez isso se deva a um problema que já foi indicado na Introdução deste trabalho: a maior parte dos comentadores de Hume parece não ter concentrado parte substancial de seus estudos em descobrir a concepção de filosofia defendida pelo nosso autor. Na maior parte dos casos, as discussões sobre esse tema limitaram-se à discussão sobre um possível ceticismo ou um possível naturalismo humiano. Não pretendemos, aqui, defender que essa discussão é datada (ainda que certamente pareça sê-lo, como veremos no Capítulo III), muito menos que não é importante (sim, ela é). Entretanto, como já dissemos, ainda que Hume possa, dependendo da leitura que fazemos de sua obra, ser considerado um cético ou um naturalista, essas denominações, por mais que possam ter sido bem explicadas por cada um dos comentadores que se ocuparam delas, não bastam para definir o que nosso autor entende por filosofia. Isso vale, também, como não poderia deixar de ser, para o que ele entende por falsa filosofia ou má filosofia. A leitura da Parte 4 do Livro 1 do Tratado, então, torna-se de suma importância para todos aqueles que quiserem investigar a concepção de filosofia defendida por Hume. Nela, o autor parece justamente tratar, à luz das partes precedentes, do que a filosofia deve ou não deve ser.

É importante explicarmos que isso não ocorre apenas porque duas seções ("Da Filosofia Antiga” e "Da Filosofia Moderna”) propõem críticas vigorosas a certas escolas filosóficas particulares. Mesmo as outras seções certamente têm algo a dizer sobre a maneira como Hume considera que a filosofia deve, ou não, ser. Ao empregar argumentos céticos contra os sentidos e contra a razão, nosso autor faz considerações que serão de grande valor para a delineação do que ele pretende que seja a sua própria filosofia. Além disso, esse ataque à confiabilidade da razão e dos sentidos acaba por se revelar importante para promover uma rejeição das filosofias anteriores, como trataremos de deixar claro em um momento posterior deste trabalho. As seções que tratam da filosofia e da moderna têm os objetos que criticam estampados já em seus títulos. Naquela em que trata da imaterialidade da alma, Hume mostra que a defesa da existência de uma alma imaterial termina por levar ao espinosismo e ao ateísmo. Até mesmo a seção em que Hume discorre sobre a identidade pessoal, de que poderíamos dizer que é apenas a visão bastante particular do eu introduzida pela filosofia de Hume,

própria filosofia deve ser. De qualquer maneira, devemos reconhecer o mérito do livro de Livingston por chamar a atenção dos estudiosos de Hume para a Parte 4 do Livro 1 do Tratado. 
parece trazer consigo uma crítica bastante pesada a uma forma de filosofia, no caso, as filosofias do sujeito ${ }^{3}$. Adiantamos que, neste capítulo, não trataremos em detalhes das seções “Do Ceticismo com relação à Razão” e “Da Imaterialidade da Alma”. Isso porque elas se concentram em mostrar de que modo uma análise, por assim dizer, lógica dessas questões leva a conclusões desfavoráveis tanto no que diz respeito à infalibilidade da razão quanto no tocante à noção de uma alma imaterial, mas não oferece grandes explicações sobre a própria concepção humiana da falsa filosofia, ao menos não sem que recorramos a uma análise cuidadosa da epistemologia desenvolvida por Hume. Desse modo, não teriam tanto a oferecer, por ora, ao tema que nos propomos a investigar aqui.

Por outro lado, parece bastante conveniente começarmos, aqui, pela análise das seções intituladas, respectivamente, “Da Filosofia Antiga” e "Da Filosofia Moderna”. Ainda que isso quebre a ordem do texto do próprio Hume, há boas razões para proceder dessa maneira. Ora, ainda que não seja na seção em que trata da filosofia antiga que nosso autor emprega pela primeira vez a expressão “falsa filosofia”, é nela que nosso autor começa uma análise mais detalhada do modo como escolas filosóficas passaram a aderir a princípios falsos, de modo que faz sentido partir daí para observar de que modo o conceito de falsa filosofia começa a ser desenvolvido. A seção que trata da filosofia moderna, por sua vez, pode ser vista como, por assim dizer, complementar à que a precede. Além disso, não podemos nos esquecer que a filosofia de Hume se pretende a ciência de uma natureza humana que pode ser conhecida não apenas quando a vemos apresentando uma solução brilhante para um problema, mas, também, quando a observamos errando. Isso fica bastante claro no primeiro parágrafo da seção sobre a filosofia antiga:

Muitos moralistas recomendam, como um excelente método para nos familiarizarmos com nossos próprios corações, bem como para conhecer nosso progresso no caminho da virtude, que lembremos nossos sonhos quando amanhecer, e os examinemos com o mesmo

\footnotetext{
${ }^{3}$ Como também trataremos de deixar mais claro posteriormente, essa crítica é, por assim dizer, auxiliada pelos argumentos céticos que Hume emprega contra a infalibilidade da razão, já que, ao tentar abalar a confiabilidade da razão que é aplicada à matemática e à geometria, além de negar que ela possa ser aplicada para o conhecimento do mundo, ele estabelece, também, uma condição importante para recusar o próprio método de filosofar das filosofias cartesianas.
} 
rigor com que examinaríamos nossas ações mais sérias e mais deliberadas. Nosso caráter ao longo deles é o mesmo, dizem eles, e aparece melhor quando o artifício, o medo e a política não têm lugar, e os homens não podem ser hipócritas nem consigo mesmos nem com os outros. A generosidade ou a baixeza de nosso temperamento, a mansidão ou a crueldade, a coragem ou a pusilanimidade influenciam as ficções da imaginação com a liberdade mais ilimitada, e revelam-se com as cores mais brilhantes. Da mesma maneira, estou persuadido de que poderia haver diversas descobertas úteis a serem feitas a partir de uma crítica das ficções da filosofia antiga (...) $)^{4}$. (HUME 31, pp. 144-5)

A mensagem, portanto, não poderia ser mais clara. Ao examinar aquilo que denomina as ficções criadas por pensadores antigos, Hume pretende estudar a própria natureza humana. Isso faz sentido porque os próprios enganos dos filósofos antigos só podem ser bem compreendidos por meio do estudo rigoroso da natureza humana. Esses princípios, como sabemos, são exatamente aquilo que nosso autor procura desvendar na maior parte de sua filosofia.

Fica evidente, então, que são muitos os motivos que nos poderiam levar a iniciar nossa investigação pelas seções em que Hume se refere à filosofia antiga e a moderna. Entretanto, não é isso que faremos. Isso porque uma série de pontos desenvolvidos por Hume nesses textos, como a crítica das noções de qualidades ocultas (no caso da filosofia antiga) e a da distinção entre qualidades primárias e secundárias (na seção sobre a filosofia moderna) fazem referências bastante explícitas à seção intitulada "Do ceticismo com relação aos sentidos”. Pode-se dizer que essa seção constitui, com aquelas que tratam da filosofia antiga e da moderna, algo como um "bloco único” em que Hume se dedica a estabelecer e a expandir uma mesma cadeia de raciocínio. Além disso, a seção do ceticismo quando aplicado aos sentidos não será importante apenas

\footnotetext{
${ }^{4}$ Several moralists have recommended it as an excellent method of becoming acquainted with our own hearts, and knowing our progress in virtue, to recollect our dreams in a morning, and examine them with the same rigour, that we wou'd our most serious and most deliberate actions. Our character is the same throughout, say they, and appears best where artifice, fear, and policy have no place, and men can neither be hypocrites with themselves nor others. The generosity, or baseness of our temper, our meekness or cruelty, our courage or pusillanimity, influence the fictions of the imagination with the most unbounded liberty, and discover themselves in the most glaring colours. In like manner, I am perswaded, there might be several useful discoveries made from a criticism of the fictions of the antient philosophy (...).
} 
como ilustração de certos aspectos das outras duas. Uma análise séria dos argumentos céticos empregados por Hume ao tratar dos sentidos será de grande importância porque, além de realmente melhorar a compreensão das duas seções em que há críticas explícitas a certas escolas filosóficas, prestará um grande auxílio quando começarmos a definir aquilo que deve ser, para Hume, a verdadeira filosofia. Tudo isso certamente justifica que nos detenhamos, antes de passar às críticas de nosso autor a maneiras mais particulares de filosofar, em uma análise detalhada da seção que trata do ceticismo com relação aos sentidos. Ainda que a leitura excessivamente colada ao texto possa parecer um tanto cansativa, ela certamente colaborará para a elucidação de uma série de aspectos importantes da filosofia humiana aos quais nos referiremos posteriormente.

\section{A análise cética dos sentidos}

Na seção que acabamos de mencionar, nosso autor se pergunta a respeito das causas que nos levam a acreditar na existência de corpos. Ele desmembra essa questão em duas outras. São elas: por que atribuímos uma existência contínua a objetos, mesmo quando eles não estão presentes aos nossos sentidos? E por que supomos que eles têm uma existência distinta da mente e da percepção? As respostas oferecidas por Hume são bem conhecidas. Nossos sentidos, diz ele, oferecem-nos apenas percepções, as quais não são capazes de nos remeter a qualquer coisa parecida com um objeto externo. Por exemplo, deixando de lado a questão da suposta identidade de uma substância pensante ${ }^{5}$, parece evidente que nossos próprios corpos nos pertencem, são partes de nós, de modo que o que quer que se nos apareça como externo a nossos corpos deve estar fora de nós mesmos. Ocorre, porém, diz Hume, que mesmo no caso daquilo que chamamos nossos próprios corpos, o que nossos sentidos nos revelam não é uma existência corpórea propriamente dita, mas apenas um conjunto de percepções, ao qual nossas mentes, por razões que ainda serão explicadas, atribuem uma existência corpórea. O mesmo ocorre, também, com sons, sabores e cheiros. Ainda que sejam vistas por pela mente como características contínuas e independentes, não parecem existir em algum tipo de extensão e, portanto, não podem ser percebidas pelos sentidos

\footnotetext{
${ }^{5}$ Como se sabe, Hume atacará essa ideia na seção sobre a identidade pessoal, de que trataremos posteriormente.
} 
como exteriores ao corpo. Até mesmo a visão, no fim das contas, não nos informa imediatamente, sem certos raciocínios ou certas experiências, sobre nada como distância ou exterioridade ${ }^{6}$.

Também a independência dos objetos não pode, segundo Hume, ser determinada pelos sentidos. A opinião que temos a esse respeito depende da experiência e da observação. De qualquer maneira, ao que parece, quando falamos de existências distintas reais, temos em mente mais a independência do que a situação externa de objetos no espaço.

Os sentidos, porém, “não nos transmitem noção alguma da existência contínua, porque não podem operar além da medida em que realmente operam" (HUME 31, p. 128). Ora, não é possível que os sentidos captem, por si mesmos, uma existência distinta, já que está fora do poder deles oferecer à mente um objeto como representado ou como original. Para mostrar um dado objeto como sendo representado, seria preciso que oferecessem à mente um objeto e uma imagem, o que eles evidentemente não fazem. Para garantir que o objeto em questão fosse apresentado como original, seria preciso que os sentidos nos transmitissem uma falsidade, que deveria estar nas relações e na situação, o que exigiria que os próprios sentidos pudessem comparar o objeto com a ideia de nós mesmos. Isso, evidentemente, não é o que acontece. De acordo com a filosofia humiana, é evidente que "nossos sentidos não oferecem suas impressões como imagens de algo distinto, independente e externo" (HUME 31, p. 126). Isso porque eles “não nos transmitem nada além de uma única percepção, e não nos dão o menor palpite sobre nada que esteja além"” (HUME 31, p. 126). Os sentidos nos trazem apenas percepções e, se não nos mostram objetos que poderiam ser a causa delas, não é possível que tragam a ideia de constância. Ora, aquilo a que chamamos objetos

\footnotetext{
${ }^{6}$ Cf. HUME 31, pp. 127-8.

7 “[...] they give us no notion of continu'd existence, because they cannot operate beyond the extend, in which they really operate.

8 " [...] our senses offer not their impressions as the images of something distinct, or independent, and external $[\ldots] ”$.

9 “[...] convey to us nothing but a single perception, and never give us the least intimation of any thing beyond".
} 
constantes e distintos são apenas percepções, as quais, sempre é bom lembrarmos (por mais evidente que isso possa parecer), cessam imediatamente quando nossos sentidos não mais as têm. Seria impossível, então, que nossos sentidos, sem o auxílio de qualquer outra faculdade ou coisa do tipo, pudessem nos transmitir qualquer coisa parecida com a ideia de uma existência contínua e independente.

Para confirmar tudo isso, Hume propõe que observemos que há três tipos de impressões transmitidas pelos sentidos. Em primeiro lugar vêm as de figura, tamanho, movimento e solidez dos corpos. Em segundo, as de cores, sabores, cheiros, sons, calor e frio. Por fim, os prazeres e dores, que surgem da aplicação de objetos a nossos corpos, como, por exemplo, o corte de uma faca. Tanto filósofos quanto o vulgo consideram que o primeiro tipo tem uma existência contínua e independente. No que diz respeito ao segundo, os filósofos discordam do vulgo, já que consideram que as impressões desse tipo dizem respeito a quem percebe, enquanto o vulgo considera que esse segundo tipo também é de qualidades que estão nos próprios objetos. Quanto ao terceiro tipo, filósofos e pessoas comuns voltam a concordar, já que ambos consideram que as impressões englobadas por ele estão apenas no percipiente ${ }^{10}$. Ora, é evidente que qualidades como cores, sons, calor e frio, na medida em que aparecem para os sentidos, existem do mesmo modo que movimento e solidez e que, portanto,a diferença entre esses dois tipos não se deve à percepção. Assim, não causa espanto que o vulgo pense poder refutar os argumentos dos filósofos modernos segundo os quais as qualidades secundárias existem apenas no sujeito simplesmente a partir do sentimento e da experiência. É evidente, também, que qualidades como cores e sons estão em pé de igualdade com a dor que é causada pelo corte de uma faca de aço, ou o prazer conferido por uma fogueira em uma noite fria. A diferença entre essas variedades perceptuais, diz Hume, não se deve aos sentidos nem à razão, mas à imaginação. Afinal, ambos os tipos são apenas "percepções que surgem de configurações e movimentos particulares de partes do corpo $^{11}$ ” (HUME 31, p. 128). A conclusão óbvia é que, no que depender apenas dos sentidos, todas as percepções são semelhantes no que diz respeito ao que nosso autor denomina a “maneira de sua existência”.

\footnotetext{
${ }^{10}$ A partir daí, teremos o que pode ser considerado a base da crítica que Hume fará, na seção sobre a filosofia moderna, da doutrina galilaica das qualidades primárias e secundárias.

11 “[...] perceptions arising from the particular configurations and motions of the parts of body [...]”.
} 
Logo em seguida, Hume afirma que, nos casos de sons e de cores, também atribuímos uma realidade distinta e contínua aos objetos independentemente da razão ou de qualquer consulta a princípios filosóficos. Isso não quer dizer, é claro, que os filósofos de maneira geral não tenham tentado fornecer argumentos para defender que objetos existem independentemente de nossos processos mentais. O que ocorre é que, além de esses argumentos serem conhecidos apenas por umas poucas pessoas, "não é por meio deles que crianças, camponeses e a maior parte da humanidade são induzidos a atribuir objetos a algumas impressões, e negá-los a outras ${ }^{12}$ (HUME 31, p. 129). Isso faz com que o vulgo e a filosofia estejam quase sempre em desacordo no que diz respeito a esse tipo de questão: enquanto os filósofos afirmam que tudo que aparece para a mente não é nada além de percepções (e, portanto, tudo que aparece à mente é descontínuo e dependente), o vulgo atribui independência e continuidade a tudo que sente ou vê. Ora, havíamos observado que, para Hume, é impossível que os próprios sentidos, tomados em si mesmos, possam servir como justificativa para qualquer doutrina que se coloque a favor da independência ou da continuidade de quaisquer objetos. $\mathrm{O}$ vulgo nunca toma esse tipo de questão como um problema porque, de certa maneira, ainda que admita não ter acesso a nada além das percepções, toma-as como se fossem, elas próprias, objetos. Isso fica evidente pelo fato de as pessoas comuns atribuírem existência contínua e independente ao que normalmente vêem ou sentem. Essa é uma opinião que podemos afirmar seguramente que não depende do entendimento. Aliás, quando identificamos percepções a objetos, é impossível, evidentemente, inferirmos a existência de qualquer objeto a partir daquilo que percebemos, ou por meio de qualquer relação de causa e efeito $^{13}$. Além disso, mesmo que distingamos percepções de objetos, ainda não temos como partir de um lado para chegar ao outro.

\footnotetext{
12 “[...] 'tis not by them, that children, peasants, and the greatest part of mankind are induc'd to attribute objects to some impressions, and deny them to others".

${ }^{13}$ É importante observarmos que o que está em jogo não pode ser desvendado por relações de causa e efeito porque, como se sabe, essa relação é, para Hume, a única base de nosso conhecimento sobre questões de fato, ou seja, sobre o mundo que percebemos. Em outras palavras, ao afirmar que é impossível inferir a existência de objetos a partir de percepções ou por meios de relações de causa e efeito, nosso autor quer dizer que simplesmente não dispomos de meios legítimos para fazer tal inferência. É possível que existam objetos externos responsáveis por nossas percepções, mas é igualmente possível que isso não ocorra, e não cabe à filosofia fazer essa investigação. O que resta, sim, à filosofia é
} 
O resultado, como não poderia deixar de ser, é que nossa razão não pode nos garantir, de maneira alguma, a existência de objetos contínuos e independentes. Essa opinião é devida, portanto, única e inteiramente à imaginação, e é por isso que Hume passa a investigar de que modo ela colabora para esse processo ${ }^{14}$. A ideia de uma existência contínua e independente deve surgir a partir da convergência de certas qualidades presentes em algumas impressões com certas qualidades da imaginação. E se dissemos algumas impressões, foi porque, como observa Hume, não são todas elas que nos transmitem essas ideias. Faz-se necessário, então, que comparemos as impressões a que atribuímos uma existência contínua e independente àquelas que vemos como perecíveis e dependentes de nossas percepções.

Hume estabelece, antes de qualquer outra coisa, que não é o facto de certa impressão ser considerada involuntária, nem sua força ou sua vivacidade, que fazem com que ela seja considerada contínua e independente. Prazeres e dores, paixões e afecções, operam com mais violência, por exemplo, que ideias como figura, extensão, cor e som, mas sempre consideramos que existem apenas enquanto percepções. Do mesmo modo, o calor de um fogo moderado é usualmente considerado algo que existe no próprio fogo, enquanto, da dor causada quando nos aproximamos demais do tal fogo, dizemos que existe apenas como percepção ${ }^{15}$.

A segunda hipótese examinada por Hume é aquela segundo a qual atribuímos continuidade e independência a impressões que parecem ter uma certa constância peculiar. Montanhas, casas e árvores, por exemplo, sempre aparecem para nós segundo uma mesma ordem. Podemos perdê-las de vista virando a cabeça ou deixando o local em que as presenciamos, mas, ao voltar nossa visão para aquele ponto novamente, elas aparecerão lá do mesmo modo como as havíamos visto anteriormente. O mesmo pode ser dito de todas as impressões que consideramos contínuas e independentes, como, por exemplo, os objetos de uma sala. E mesmo que tais objetos possam sofrer várias mudanças, estas parecem estar sujeitas a certa coerência, o que faz com que, por meio

\footnotetext{
investigar como é que terminamos por acreditar em objetos contínuos e independentes de nossas percepções quando nosso entendimento simplesmente não pode nos dar qualquer garantia nesse sentido.

${ }^{14}$ Cf. HUME 31, p. 129.

${ }^{15}$ Cf. HUME 31, p. 129.
} 
de um certo raciocínio de causa e efeito, mantenhamos, nesse caso, a impressão de existência contínua. "Quando retorno ao meu quarto depois de ter estado ausente por uma hora”, diz Hume, "não encontro minha lareira na mesma situação em que a deixei; mas estou acostumado, por conta de outras situações, a ver uma alteração semelhante produzida em um período de tempo semelhante, estando eu presente ou ausente, próximo ou distante $^{16, "}$ (HUME 31, p. 130). Fica evidente, então, que essa constância e essa coerência são características daquilo a que denominamos objetos externos.

Torna-se necessário investigar, então, de que modo essas qualidades produzem as ideias de continuidade e de independência. Hume começa analisando a coerência e, antes de qualquer outra coisa, trata de estabelecer que a coerência entre aquilo que denominamos objetos externos é bastante diferente daquela que observamos, por exemplo, em nossas paixões. Estas últimas certamente parecem estar conectadas e depender umas das outras, mas não temos por que supor que, quando estão inoperantes, continuam a existir e a operar de modo a manter essa dependência. No caso dos objetos externos, porém, as coisas ocorrem de modo bastante diferente. Hume ilustra essa afirmação com o seguinte exemplo ${ }^{17}$ : ele se imagina sentado em seu quarto, de frente para o fogo. Todos os objetos que atingem seus sentidos parecem estar a alguns metros dele. Sua memória, diz ele, o informa da existência de muitos objetos, mas não vai além da existência passada deles. Além disso, nem os sentidos nem a memória oferecem a ele qualquer informação sobre a existência contínua dos tais objetos. Enquanto pensa sobre isso e sobre outros assuntos, ele ouve subitamente um barulho como o de uma porta girando em suas dobradiças e, pouco tempo depois, vê um mensageiro avançando em direção a ele. Nosso autor, então, afirma que nunca notou esse barulho ser emitido por nada além do movimento de uma porta e, portanto, conclui que o fenômeno que acabou de presenciar será "uma contradição de toda a experiência passada, a não ser que a porta, que eu lembro estar situada do outro lado do aposento, ainda exista ${ }^{18}$ (HUME 31,

\footnotetext{
16 "When I return to my chamber after an hour's absence, I find not my fire in the same situation, in which I left it: But then I am accustom'd in other instances to see a like alteration produc'd in a like time, whether I am present or absent, near or remote".

${ }^{17}$ Cf. HUME 31, pp. 130-1.

18 " [...] a contradiction to all past experience, unless the door, which I remember on the other side of the chamber, be still in being”.
} 
p. 131)”. Além disso, ele sempre observou que corpos humanos são dotados de algo que costumamos chamar gravidade, que impede que o mensageiro tenha flutuado até a porta do quarto em questão, que não está situado no andar térreo. Desse modo, Hume conclui que a escada que levava ao quarto não deve ter deixado de existir por conta de sua ausência. Mas isso ainda não é tudo: o mensageiro entrega uma carta que, pela caligrafia e pela assinatura, parece ter sido escrita por um amigo determinado, que está em um país distante. É evidente para Hume que seria impossível dar conta desse fenômeno, que é conforme à experiência passada, sem supor os efeitos e a existência contínua de correios e balsas, de acordo com a memória e a observação.

Ocorre, porém, que esse caso envolvendo o mensageiro e a carta refere-se, de certa maneira, a uma contradição à experiência passada. Hume narra que apenas ouviu o ruído da porta e viu o mensageiro quanto este já estava próximo. Porém, em casos anteriores, sempre ouviu o tal ruído quando presenciava uma porta se abrindo, e sempre viu alguém entrar pela porta já aberta. O que acontece, portanto, é que a suposição quase arbitrária de que a porta foi aberta e o mensageiro entrou por ela apresenta-se cada vez mais como a única capaz de resolver a tal contradição. Assim, no caso que acabamos de narrar, bem como em várias situações cotidianas, somos levados a supor a existência contínua dos objetos para conectar suas aparências passadas e presentes, estabelecendo a união entre umas e outras, do modo como somos conduzidos, por meio da experiência, a considerar mais apropriado. É por esse processo que somos levados a considerar aquilo que chamamos mundo exterior como algo contínuo.

Poderia parecer, então, que é apenas o hábito que nos leva a atribuir a certas percepções o caráter de continuidade e de independência que as caracteriza, para nossas mentes, como objetos externos. E se assim fosse, haveria, certamente, uma enorme semelhança entre o processo pelo qual atribuímos a certos objetos o caráter de contínuos e independentes e aquele pelo qual estabelecemos as relações de causa e efeito. Para Hume, esse definitivamente não é o caso. Isso porque o hábito, além de ser o resultado da grande repetição de certas impressões, não pode, de maneira alguma, exceder a própria regularidade que observamos. Afirmar que o hábito é o único responsável pela crença na existência contínua, portanto, equivaleria a dizer que um hábito pode se formar sem corresponder a percepção alguma. E ainda assim, ao inferir a existência contínua e independente de certos objetos, pretendemos atribuir a eles uma regularidade maior do que aquela que observamos em nossas percepções. Ora, é bastante claro que 
jamais percebemos a regularidade se mantendo em momentos em que não estamos presentes. Concluímos, então, que o hábito não pode ser o único fator que explica a atribuição de continuidade e independência a certos objetos. Hume deve, portanto, invocar algum outro princípio que contribua para esse acontecimento. O que ele afirmará é que "a imaginação, quando posta em qualquer cadeia de pensamentos, dispõe-se a continuar, mesmo quando seus objetos se desgarram dela, e, como um galeão posto em movimento pelos remos, prossegue em seu curso, sem nenhum impulso novo ${ }^{19, ”}$ (HUME 31, p. 132). O que a mente faz, então, ao perceber a coerência entre os vários objetos que percebe, é continuar seu movimento e tornar a uniformidade tão completa quanto for possível. A suposição de sua existência contínua basta, segundo Hume, para esse propósito, e faz com que tenhamos a noção de uma coerência muito maior do que aquela que poderíamos obter apenas por meio de nossos sentidos.

Esse princípio ainda não parece suficiente, diz Hume, para explicar a existência contínua. Ele pretende apresentar, também, uma explicação a partir da constância, depois da qual ele espera que a crença na existência contínua seja finalmente explicada. A partir daí, espera que decorra a ideia de existência independente. Nosso autor inicia essa tarefa afirmando que nos acostumamos a observar a constância de certas impressões. A percepção de um oceano, por exemplo, retorna depois que viramos a cabeça ou fechamos os olhos por alguns instantes. Porém, em um caso como esse, a interrupção é contrária à ideia de identidade, e tendemos a considerar a primeira impressão aniquilada e a segunda, como criada mais recentemente. Para nos livrarmos desse inconveniente, disfarçamos, tanto quanto possível, a interrupção, o que é feito pela suposição de que essas duas percepções estão conectadas por uma existência real que somos incapazes de perceber. Essa ideia ganha mais força e vivacidade ${ }^{20}$ a partir das lembranças de impressões interrompidas e de uma propensão que elas nos conferem, a saber, a de supô-las como sendo apenas uma. E para justificar essas afirmações, diz Hume, é preciso explicar quatro pontos: o princípio de individuação (o que constitui para nós a identidade de um objeto), o motivo por que a semelhança de

\footnotetext{
${ }^{19}[\ldots]$ the imagination, when set into any train of thinking, is apt to continue, even when its object fails it, and like a galley put in motion by the oars, carries on its course without any new impulse”.

${ }^{20}$ Isso quer dizer, em termos humianos, que passamos a acreditar nelas. Como se sabe, a crença nada mais é, para Hume, que um grau maior de força e vivacidade. Cf. HUME 31, seção 1.3.7.
} 
impressões interrompidas nos leva a atribuir a elas uma identidade, a propensão a unir essas impressões por meio de uma existência contínua e a força e a vivacidade da ideia que surge com essa propensão.

Hume começa a enfrentar o primeiro ponto expondo uma dificuldade: no caso da afirmação de que um objeto é igual a si mesmo, a ideia expressa pela palavra “objeto” deve ser distinta daquela expressa pela expressão "si mesmo", já que, se não for assim, a frase simplesmente não quer dizer nada. A ideia de número não resolve o problema, já que pensar em “um” objeto nos dá a ideia de unidade, não de identidade. Ocorre, porém, que, evidentemente, a multiplicidade também não confere a ideia que procuramos. Ora, se tanto a unidade quanto a multiplicidade são incompatíveis com a identidade, esta deve estar em algum ponto entre as outras duas. Ocorre, porém, que isso parece impossível, já que não temos como pensar um meio termo entre unidade e multiplicidade.

Com o intuito de resolver esse problema, nosso autor recorre à ideia de tempo, ou duração. De acordo com a Seção 5 da Parte 2 do Livro 1 do Tratado, a ideia de tempo exige a de sucessão. Isso quer dizer que, para que tenhamos a ideia do tempo, é preciso que observemos mudanças nos objetos que percebemos ao nosso redor. Se observarmos algo que parece não sofrer alteração alguma, só poderemos pensar nesse objeto como existente no tempo porque o comparamos com objetos que, concomitantemente, passam por mudanças. O tempo é, para Hume não exatamente uma percepção, mas uma maneira de perceber, derivada da observação das várias mudanças sofridas por objetos. É, portanto, inseparável da ideia de sucessão. De qualquer maneira, ao considerar um dado objeto como existente entre dois pontos no tempo, podemos ver esses dois pontos como simultâneos, caso em que esse objeto terá que ser “duplicado ${ }^{21 \text { ”, }}$ ou como existindo em momentos que fazem parte de uma mesma "linha" de tempo, mas não do mesmo instante. Este segundo caso, diz Hume, é que nos dá a ideia de identidade, que, portanto, nada mais é que a ideia de um objeto que é o mesmo em dois

\footnotetext{
${ }^{21}$ Em outras palavras, se tomamos o mesmo objeto em um mesmo instante no tempo, estamos falando em dois objetos. Quando pensamos um objeto que existe em dois instantes que são simultâneos, o que temos é a ideia de número.
} 
pontos diferentes do tempo. Em outras palavras, a identidade pode ser considerada a mesma coisa que a não variação de um objeto que percebemos por um dado período ${ }^{22}$.

É preciso explicar, então, por que essa constância de nossas percepções nos leva a atribuir a elas uma "perfeita identidade numérica”, mesmo que haja grandes intervalos entre as várias aparições de um mesmo objeto ${ }^{23}$. Nosso autor iniciará lembrando que, quando uma relação qualquer associa duas ideias na imaginação, fazendo com que seja fácil passar de uma para a outra, torna-se freqüente confundirmos as duas ideias em questão. A relação de semelhança é a que causa o maior número de enganos desse tipo, já que implica "não apenas causa uma associação de ideias, mas também de disposições, e faz com que concebamos uma ideia por um ato ou uma

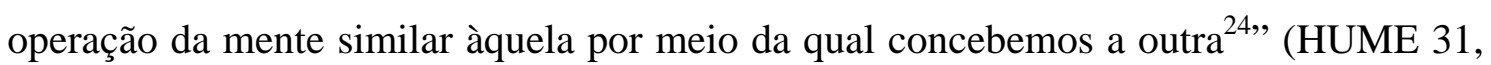
p. 135). Podemos mesmo afirmar que, nesses casos, a mente passa de uma ideia à outra sem perceber a mudança. Desse modo, quando temos a percepção de um objeto invariável (e, portanto, atribuímos a ele uma identidade) e, depois de uma interrupção, temos uma nova percepção, que confundimos com a primeira, nossas disposições também são afetadas. Se supusermos que um objeto continua o mesmo por algum tempo, certamente acreditaremos que a mudança ocorreu apenas no tempo, já que nossa mente não se esforçará para produzir qualquer imagem ou ideia nova daquele objeto. A mente faz apenas o esforço necessário para continuar aquela mesma ideia já presenciada e, no fim das contas, mesmo a passagem de um momento a outro mal é sentida, não se distinguindo por qualquer percepção ou ideia diferente.

\footnotetext{
${ }^{22}$ Cf. HUME 31, p. 134.

${ }^{23}$ Nesse ponto do texto, Hume nos lembra que está tentando explicar as opiniões do vulgo e, portanto, deve se restringir a elas. Isso é importante para que não percamos de vista que nosso filósofo, nessa seção, busca explicar o funcionamento usual da mente em situações cotidianas. Não pretende, nesse ponto, criticar ou explicar qualquer ideia filosófica sobre o mundo exterior (tarefa de que se ocupará posteriormente, como veremos). Isso é importante porque ele passará a usar as palavras object e perception como sinônimos, e avisará quando retornar a uma linguagem "mais filosófica". É importante que nos lembremos disso também porque, ainda que essa seção certamente seja importante para embasar as críticas de Hume a certas escolas filosóficas, acabaremos por recorrer a ela em bases diferentes quando, posteriormente, tratarmos da concepção humiana da verdadeira filosofia.

24 “[...] not only causes an association of ideas, but also of dispositions, and makes us conceive the one idea by an act or operation of the mind, similar to that by which we conceive the other".
} 
É importante lembrarmos que, para Hume, é assim que se explica a opinião de todas as pessoas comuns, ou seja, todos aqueles que não são filósofos. Isso quer dizer que essa explicação vale para todos nós, ao menos na maior parte do tempo. O vulgo, e mesmo os filósofos quando não estão desenvolvendo uma teoria sobre o mundo exterior, pensam em suas percepções como sendo os próprios objetos, simples assim. E como a interrupção de uma percepção parece contrária à ideia de identidade, já que na prática ela nos revela duas percepções diferentes, ela faz com que nos sintamos perdidos no que diz respeito a reconciliar essas duas opiniões opostas, a saber, a da identidade e a de duas aparições distintas. É exatamente a passagem suave da imaginação entre as ideias dessas duas percepções que fará com que atribuamos a ambas uma identidade perfeita. Em outras palavras, temos certa propensão a unir essas percepções que aparecem para nós como sendo várias, ainda que certamente muito semelhantes. Explicar essa propensão é justamente o terceiro ponto a que Hume se havia proposto.

Segundo ele, qualquer contradição, seja aos sentimentos ou às paixões, causa uma grande inquietude, quer a tal contradição se deva à oposição de fatores externos ou de princípios internos. Por outro lado, é claro que, se algo estiver de acordo com nossas propensões naturais, será causa de um inegável prazer ${ }^{25}$. Temos, nesse caso, a inquietude que surge com a oposição de dois princípios contrários, a interrupção de nossas percepções e a ideia de identidade. Ainda que nossa imaginação nos faça considerar como um só objeto certas percepções constantes, o fato é que nossas percepções são interrompidas um número demasiado de vezes, o que faz com que seja difícil ignorar as tais interrupções. Como, até aqui, nossas percepções têm sido identificadas à existência, parece que estamos envolvidos com uma contradição inescapável. É preciso que Hume explique, então, de que modo é possível que a interrupção de uma aparição não se iguale à interrupção da existência de um suposto objeto. Para isso, ele adiantará, ainda que de forma bastante resumida, argumentos que desenvolverá posteriormente, na seção em que tratará da identidade pessoal.

Antes de apresentar esses argumentos, Hume nos lembra que a questão não é se a mente forma alguma conclusão referente à existência contínua dos objetos. Isso parece já estar bem estabelecido. O problema reside no modo como a mente formula essas conclusões. Ora, a maior parte dos homens, incluídos aí os filósofos, acredita, na maior

\footnotetext{
${ }^{25}$ Cf. HUME 31, pp. 136-7).
} 
parte do tempo, que nossas percepções são os únicos objetos de que "dispomos", e que esses objetos não desaparecem quando deixamos de percebê-los. Quando não estamos presentes, dizemos que certo objeto existe, ainda que não o sintamos naquele momento. Surgem, então, algumas perguntas. Como nos satisfazemos com a suposição de que uma percepção esteja ausente da mente sem que isso implique sua aniquilação? De que modo concebemos que um objeto se torna presente, sem a nova criação de uma percepção ou uma imagem? E o que queremos dizer com ver, sentir, perceber?

Colocados esses problemas, Hume adianta, como dissemos, os argumentos que retomará posteriormente de maneira detalhada. Afirma que a mente não é nada além de "um feixe ou uma coleção de diferentes percepções, unidas por certas relações, e que supomos, ainda que falsamente, ser dotada de perfeita simplicidade e identidade ${ }^{26,}$ (HUME 31, p. 137). Ora, já que toda percepção é distinta de qualquer outra e poder ser considerada como existente de maneira separada, não há qualquer absurdo em separar qualquer percepção da mente propriamente dita, ou seja, em cortar todas as relações com aquela massa conectada de percepções que constituem um ser pensante. E é o mesmo raciocínio que nos dá uma resposta à questão seguinte: se falar em percepções não torna essa separação absurda, o mesmo pode ser dito do nome “objeto”, já que o termo “objeto" e o termo "percepção” querem dizer a mesma coisa. Objetos são vistos, sentidos, percebidos e, assim, colaboram para ampliar o número de percepções do tal feixe a que nos havíamos referido. Eles o fazem por meio de reflexões e paixões presentes, bem como do provimento de ideias, as quais ficam armazenadas por meio da memória. Portanto, um ser contínuo e ininterrupto pode estar ora presente à mente, ora ausente dela, sem que isso implique que ele deixa de existir. Não há contradição alguma nisso e, na verdade, é fácil satisfazermos nossa inclinação a essa hipótese, como que fingindo a existência de um ser contínuo que preenche os intervalos em que nossa mente não percebe o objeto em questão.

Ocorre, porém, que não apenas fingimos a existência de seres contínuos, mas acreditamos nela. Isso é o que leva Hume a enfrentar o quarto ponto a que fizemos referência anteriormente, ou seja, ele deve explicar a força e a vivacidade adquiridas pela hipótese da existência contínua. A explicação oferecida por nosso autor exige o

\footnotetext{
26 “[...] a heap or collection of different perceptions, united together by certain relations, and suppos'd, tho' falsly, to be endow'd with a perfect simplicity and identity”.
} 
recurso a aspectos mais básicos de sua teoria do conhecimento. Como se sabe, Hume divide as percepções da mente humana em impressões e ideias. As primeiras são percepções mais vívidas, como aquelas que temos por meio dos sentidos ou das paixões. As ideias, por sua vez, são cópias das impressões e, portanto, mais fracas. Quando nosso autor fala em ideias, ele fala nas percepções que temos ao pensar em algo, ou ao lembrar algo. Além disso, devemos nos lembrar de que as impressões conferem certa vivacidade às ideias diretamente relacionadas a elas. Isso faz com que a passagem da impressão à ideia seja bastante suave, de modo que a mudança mal é percebida pela mente. Esta é “excitada pela impressão vivaz, e essa vivacidade é transmitida à ideia relacionada, sem qualquer grande diminuição na passagem, em razão da transição suave e da propensão da imaginação ${ }^{27, " ~(H U M E ~ 31, ~ p . ~ 138) . ~}$

Ora, podemos supor que essa propensão é ajudada por algum outro princípio, além da relação que acabamos de mencionar. É exatamente esse o caso: nossa memória, diz Hume, nos mostra uma vasta gama de casos em que tivemos percepções perfeitamente semelhantes, que retornam ao longo do tempo. A semelhança, como já vimos, torna-nos propensos a ver essas percepções como uma e a mesma coisa, além de nos conferir, é claro, também uma propensão a conectar essas impressões por meio da suposição de uma existência contínua, com o objetivo de justificar a ideia de identidade e evitar aquilo que poderia ser dito a contradição em que as interrupções de uma dada impressão parece nos envolver. Vem daí a propensão a fingir a existência contínua. Se lembrarmos que essa propensão surge de ideias que, presentes à memória, permanecem dotadas de enorme vivacidade, não é difícil compreender de que modo essa ficção ganha força em nossas mentes e, portanto, faz com que acreditemos efetivamente na existência de corpos. E se podemos atribuir uma existência contínua a objetos que nunca havíamos presenciado, é porque a maneira como se apresentam para nós é semelhante àquela constante e coerente que já havíamos observado em outros objetos a que atribuímos existência contínua. Nesse ponto, é claro, o hábito desempenha um papel de grande importância.

\footnotetext{
27 “[...] excited by the lively impression; and this vivacity is convey'd to the related Idea, without any great diminution in the passage, by reason of the smooth transition and the propensity of the imagination".
} 
Tendo mostrado o modo como considera que obtemos a ideia da existência contínua dos objetos, Hume trata, em seguida, da ideia de existência independente, que é, para ele, decorrência direta da ideia de existência contínua. Essas duas ideias serão, para ele, a base de uma noção que teria sido aceita pela filosofia, de forma geral: a ideia de que nossas percepções não são contínuas ou independentes, mas dizem respeito a objetos que, esses sim, existem dessa maneira. Hume faz uma crítica bastante ferrenha ao longo do resto da seção sobre o ceticismo com respeito aos sentidos. Essa crítica tem início com um argumento cético bastante conhecido: ao pressionar um olho com um dedo, imediatamente passamos a ver todos os objetos como que duplicados, sendo que sempre uma “versão" de cada objeto estará ligeiramente distante de seu lugar apropriado. E, como sabemos muito bem, ninguém atribui existência contínua a essas percepções “dobradas”, ainda que elas sejam da mesma natureza que as “originais”. A conclusão é que nossas percepções sempre dependem da condição de nossos órgãos, o que apenas é confirmado, digamos, pelo aparente aumento ou a aparente diminuição de um objeto conforme nos aproximamos ou nos afastamos dele. A conseqüência natural dessa observação é que, evidentemente, nossas percepções não têm uma existência contínua e independente.

Os filósofos, é claro, chegaram a essa conclusão e, para resolver essa dificuldade, trataram de distinguir percepções de objetos. As primeiras, então, deveriam ser consideradas passíveis de interrupção e perecíveis, dependentes da mente. Quanto aos objetos, seriam tratados como contínuos e independentes. Hume, é claro, rejeitará esse sistema que, além de ser apenas um paliativo para o problema original, acaba gerando vários outros. Segundo nosso filósofo, não há qualquer princípio, seja do entendimento ou da fantasia, que permite que concluamos o que ele chama a doutrina da dupla existência de percepções e objetos. Apenas passando pela opinião aceita pelo vulgo, ou seja, a da identidade e da continuidade de nossas percepções (confundidas pelos homens comuns com os próprios objetos), é que poderíamos chegar à conclusão de que nossas percepções e os objetos são coisas distintas, sendo que apenas os objetos têm uma existência contínua. Hume se propõe, então, a provar, em primeiro lugar, que a doutrina da dupla existência não tem nada que a recomende à razão ou à imaginação e, em segundo, que ela tira toda a sua força da doutrina normalmente aceita pela maioria dos homens. 
O primeiro desses dois pontos não parece difícil de ser provado. Com relação à razão, Hume começa dizendo que as únicas coisas de cuja existência estamos certos são nossas percepções. Além disso, como se sabe, a única maneira pela qual podemos inferir uma coisa a partir de outra, na filosofia humiana, é pela relação de causa e efeito. Essa ideia, por sua vez, “é derivada de nossa experiência passada, pela qual descobrimos que dois seres estão constantemente unidos, e estão sempre presentes de uma só vez à mente 28 ”, (HUME 31, p. 140). Ora, isso permite que extraiamos inferências que dizem respeito à relação entre diferentes percepções, mas nunca entre percepções e objetos, já que simplesmente nunca tivemos acesso a eles e, portanto, não teríamos como estabelecer uma relação de causa e efeito que os envolvesse.

A impossibilidade de que a doutrina da dupla existência seja recomendável à imaginação parece ser mais difícil de provar. De qualquer maneira Hume procede, pedindo que o leitor conceda que nossas percepções são sempre interrompidas, fragmentadas, e que, ainda que possam ser extremamente semelhantes, nunca são perfeitamente idênticas. Desafia-o, então, a provar de que modo a imaginação poderia, a partir disso, passar imediatamente a acreditar em outra existência, semelhante às percepções no que diz respeito à sua natureza, mas contínua e independente. Enquanto isso não for feito, Hume considerará melhor aceitar que, em situações normais, a mente humana funciona segundo a maneira que ele descreveu, confundindo percepções e objetos.

Quanto ao fato de a doutrina da dupla existência decorrer daquilo que é normalmente aceito pelo vulgo, ou seja, a hipótese segundo a qual nossas próprias percepções de algum modo permanecem mesmo quando não as percebemos, Hume aceita que ele possa ser concluído imediatamente quando percebemos que a dupla existência não é recomendável de forma alguma aos sentidos ou à razão. Ora, se um sistema filosófico toma posse de tantas mentes, em especial daquelas que não se dedicaram tão intensamente a esse tema, deve tirar sua autoridade da doutrina comum, já que não a tira de qualquer outra fonte. A imaginação, diz Hume, percorre o seguinte caminho: nossas percepções são os únicos objetos e, não importa quão fragmentadas elas sejam, atribuímos a elas o que chamamos identidade. As interrupções são contrárias

\footnotetext{
28 “[...] is deriv'd from past experience, by which we find, that two beings are constantly conjoin'd together, and are always present at once to the mind”.
} 
à identidade e, portanto, a imaginação, pelo processo que já explicamos, passa a considerar que elas não se aplicam além da aparência e que, portanto, a percepção (ou objeto) realmente continua a existir, ainda que esteja ausente. Porém, um mínimo de raciocínio destroi essa opinião, já que mostra que nossas simples percepções, consideradas em si mesmas, são dependentes e, portanto, não poderiam ser ininterruptas. Os filósofos, diz Hume, aceitam a dependência e, portanto, deveriam simplesmente recusar a racionalidade de uma existência contínua, mas não é o que fazem. Isso porque, em suas investigações filosóficas, são influenciados por seus instintos, pela natureza. Esta, como não poderia deixar de ser, pode se sobrepor à reflexão calma e profunda mesmo no próprio curso da investigação filosófica, impedindo que pensadores extraiam todas as consequências de uma descoberta. Por isso é que, mesmo reconhecendo a dependência de nossas percepções, os filósofos ainda precisam desesperadamente buscar salvaguardar algo de contínuo e independente. E como não podem, por outro lado, simplesmente abandonar completamente a razão, é preciso que criem uma hipótese que parece compreender tanto o princípio da razão quanto o da imaginação. É daí que surge, de acordo com Hume, a doutrina da dupla existência, que “agrada nossa razão, reconhecendo que nossas percepções dependentes são interrompidas e diferentes e, ao mesmo tempo, é agradável à imaginação, por atribuir uma existência contínua a outras coisas, às quais damos o nome de objetos ${ }^{29,}$ (HUME 31, p. 142). É por isso que Hume considera a doutrina da dupla existência a prole monstruosa de dois princípios contrários que são abraçados pela mente ao mesmo tempo e, no fim, apesar de contraditórios, incapazes de destruir um ao outro. Nossa razão não permite que estejamos plenamente convencidos da continuidade que nossa imaginação nos inclina o tempo todo a reconhecer. Se estivéssemos plenamente convencidos de que nossas percepções são contínuas, idênticas e independentes, não cairíamos na tentação da doutrina da dupla existência, já que nos satisfaríamos com a hipótese de que as percepções são os únicos objetos e não quereríamos ir além. Por outro lado, se conseguíssemos nos convencer completamente de que nossas percepções são perecíveis, simples assim, não sentiríamos necessidade de recorrer à doutrina da dupla existência e nos limitaríamos a admitir que o que temos são percepções

\footnotetext{
29 “[...] pleases our reason, in allowing, that our dependent perceptions are interrupted and different; and at the same time is agreeable to the imagination, in attributing a continu'd existence to something else, which we call objects".
} 
interruptas e efêmeras. Se a doutrina da dupla existência encontrou seguidores, foi porque sentimos a necessidade de aderir, ao mesmo tempo, a dois princípios opostos. Nesse sentido, essa teoria filosófica tem como uma grande vantagem o fato de pagar tributo à opinião do vulgo, o que permite que os filósofos satisfaçam sua razão quando ela oferecer qualquer desconforto e, em caso de qualquer falha ou desatenção, ou caso se encontrem em uma situação em que estão fora de seus gabinetes convivendo com pessoas comuns, concede-lhes a oportunidade de retornar alegremente às concepções vulgares.

Existem outras particularidades da doutrina da dupla existência que permitem, segundo Hume, que percebamos quanto ela é tributária da fantasia. Nosso autor se propõe a examinar duas delas. A primeira é que supomos que os objetos externos são semelhantes às nossas percepções. O que Hume observa, aqui, é que mesmo que fosse possível, por meio da relação de causa e efeito, concluir, a partir de nossas percepções, que existem objetos externos, não haveria como verificar se eles se assemelham a elas de algum modo. Assim, essa opinião decorre de uma qualidade da imaginação à qual Hume recorre constantemente ao discutir o ceticismo com respeito aos sentidos, a saber, o fato de a imaginação formar ideias a partir de impressões precedentes. Como não concebemos nada além de percepções, é natural que tudo se assemelhe a elas. A segunda é que tendo suposto que, de maneira geral, os objetos se assemelham a nossas percepções, aceitamos automaticamente que cada objeto se assemelha à percepção causada por ele. Isso porque a relação de causa e efeito (que apenas imaginamos estar agindo nesse caso) faz com que juntemos a ela a de semelhança, o que se deve ao fato de termos uma propensão a completar toda e qualquer união pelo acréscimo de novas relações àquelas que havíamos observado.

Hume encerra a seção que trata do ceticismo com relação aos sentidos em uma nota melancólica. Depois de haver afirmado que deveríamos ter uma fé implícita em nossos sentidos, e que era essa a conclusão a que pretendia chegar ao fim de seus raciocínios, ele parece ter obtido justamente o efeito oposto. A concepção popular acerca desse problema está imersa em diversas dificuldades e os filósofos, além de não terem conseguido se desembaraçar delas, ainda criaram outras tantas. Nosso autor admite, então, que a dúvida cética acerca desse tema não pode jamais ser superada e é, de certa maneira, uma consequência inevitável de uma reflexão intensa e profunda sobre o assunto. No fim das contas, o que resta a Hume é confiar em um certo descuido, uma 
certa desatenção, como um remédio para as dificuldades em que se encontra ${ }^{30}$. Assim, esperando que o leitor, independentemente do que pense naquele momento, volte em breve a crer na existência de um mundo interior e um exterior, Hume se propõe a aproveitar o momento e analisar, antes de prosseguir em sua investigação sobre as impressões, alguns sistemas antigos e modernos que dizem respeito a percepções e a objetos, esperando que, no fim das contas, isso possa ser de alguma utilidade.

Antes de acompanharmos a análise que Hume fará da filosofia antiga e da moderna, convém que nos detenhamos, por alguns instantes, em verificar o que pode ser extraído, desde já, para nosso propósito de verificar o que nosso autor escreve, em seus textos de epistemologia, sobre as formas falsas da atividade filosófica. Seria no mínimo injusto, afinal de contas, encararmos uma análise detalhada da seção "Do Ceticismo com relação aos Sentidos” apenas como uma preparação de terreno. Ainda que esse tenha sido um de nossos propósitos, existe algo que não podemos deixar de observar: apesar do tom melancólico em que nosso autor encerra a referida seção, sabemos que, ao final do Livro I do Tratado, o descuido a que ele se referiu será parte de uma tábua de salvação que ele considerará bastante efetiva. Mesmo que ainda não tenha chegado o momento de tratarmos disso em maiores detalhes, precisamos ficar atentos a esse ponto para não perder de vista o fato de que, ainda que Hume não tenha dúvidas de que os motivos pelos quais o vulgo acredita na existência contínua e independente dos objetos externos são completamente fictícios, ele não parece censurar, nesse caso, a opinião das pessoas comuns. O alvo, até onde podemos perceber, é uma tese que ele denomina filosófica, a saber, a doutrina da dupla existência. Que o vulgo ceda à imaginação e acredite (por mais irracional que isso seja) na existência contínua do que seriam suas próprias percepções não é algo apenas perdoável, mas algo que parece não constituir um problema. Posteriormente, veremos que a filosofia humiana, por trabalhar apenas com percepções, compartilha com o senso comum algo como um ponto de partida, o que só é

\footnotetext{
${ }^{30}$ Como veremos no Capítulo III, o "descuido” a que Hume se refere é um aspecto essencial do que ele considera a verdadeira filosofia. E é preciso deixar claro desde já que, ao depositar suas esperanças em no tal descuido, o que nosso filósofo pretende não é abrir mão do rigor. O que está em jogo, aí, é delimitar o que pode ou não ser objeto de uma investigação abstrusa. O que chamamos de descuido ou desatenção é o que permitirá que Hume simplesmente pressuponha a realidade dos objetos percebidos e aplique a eles, sem grandes perturbações, os princípios que desenvolve ao longo do Livro 1 do Tratado e de toda a primeira Investigação.
} 
possível porque nosso autor reconhece que não há filosofia se não pudermos pressupor a existência de $\operatorname{corpos}^{31}$. Isso não quer dizer necessariamente que Hume afirma a existência deles. Ele apenas considera que não é possível filosofar sem tratar aquilo que comumente chamamos objetos externos como se realmente fossem objetos externos. De qualquer maneira, esse é um tema bastante extenso, e é mais conveniente que nos ocupemos dele apenas no momento apropriado.

Voltemos, pois, àquele que parece ser o verdadeiro "alvo" de Hume na seção “Do Ceticismo com relação aos Sentidos”, ou seja, à doutrina da dupla existência. Ficou evidente, pelo tratamento conferido a ela, que estamos diante de uma teoria considerada por Hume como inaceitável. Não satisfaz plenamente a imaginação e, certamente, não pode ser considerada racional. Nosso autor chega mesmo a denunciar uma manobra bastante curiosa de inversão por parte daqueles que abraçam essa doutrina, a de tratar nossas percepções como causas de objetos aos quais elas se assemelham quando, na verdade, a própria suposição dessa semelhança só é possível porque nunca temos nada em nossa mente além de percepções, de modo que nos seria impossível imaginar objetos completamente diferentes delas. De qualquer maneira, a dupla existência é uma doutrina que, por adular alternadamente a razão e as paixões, conquistou um grande número de partidários. Talvez não seja mesmo exagero dizer que, para Hume, essa doutrina é aceita pela maior parte dos filósofos. E ao tentar explicar as razões pelas quais uma doutrina que parece tão disparatada conseguiu adquirir tamanha força, ele parece já ter iniciado o trabalho que se propõe um pouco mais tarde, no início da seção “Da Filosofia Antiga”. Em outras palavras, o que parece é que, ao verificar de que maneira a doutrina da dupla existência foi capaz de ganhar um grande número de partidários, Hume parece já se ter posto a seguir o conselho dos moralistas que recomendam que observemos nossos sonhos. Antes de mencionar essa recomendação, ele já observa uma forma falsa de filosofia para aprender algo sobre a natureza humana, e já podemos extrair alguns (poucos) resultados desses primeiros sonhos observados por nosso autor. Em primeiro lugar, fica evidente que ao menos uma forma da falsa filosofia surgirá como uma completa recusa de uma postura bem estabelecida entre os homens comuns. Ora, já começa a ficar evidente que, segundo Hume, ainda que ninguém possa ser filósofo o tempo todo, a experiência nos mostra que uma falsa teoria filosófica não

\footnotetext{
${ }^{31}$ Ver Capítulo III.
} 
precisa ter compromisso algum com a realidade experimentada. Não devemos nos esquecer de que, ainda que a doutrina da dupla existência ofereça ao filósofo a possibilidade de se comportar como um homem comum quando a situação exigir, e ainda que o filósofo certamente aprecie tanto esse conforto quanto aquele que a doutrina da dupla existência pode fornecer à sua imaginação, o conteúdo dessa doutrina é totalmente incompatível com aquilo que é aceito pelo homem comum, que, por sua vez, certamente não está pronto a aceitar a ideia de que suas percepções são apenas cópias ligeiramente semelhantes a objetos reais que ele, no fim, é completamente incapaz de acessar. Hume desenvolve um pouco mais a relação entre o pensamento do vulgo e o do falso filósofo na seção em que trata da filosofia antiga, de modo que parece conveniente conferirmos, agora sim, alguma atenção a ela.

\section{Filosofia antiga, filosofia moderna e falsa filosofia}

Como já vimos, não são poucos os motivos para que investiguemos a seção em que Hume faz a crítica da filosofia antiga. Essa seção constitui um momento em que ele parte assumidamente de sua teoria do conhecimento para criticar toda uma escola ou toda uma maneira de filosofar e, portanto, certamente tem muito a oferecer para quem quer que se interesse por descobrir o que é, para nosso autor, a falsa filosofia. O que tentaremos fazer a seguir, portanto, será partir dessa seção para mostrar mais algumas características daquilo que Hume considera a filosofia em suas formas falsas e começar a estabelecer que, para nosso autor, os falsos filósofos não cometem apenas enganos. Parece haver algo errado não apenas nas conclusões a que eles chegam por meio de seus sistemas, mas com a própria maneira pela qual eles filosofam. Além disso, não devemos perder de vista que, como já foi dito, essa análise da atividade filosófica em suas formas falsas não deve ser vista apenas como um ataque a elas: essa crítica realizada por Hume é, também, uma investigação dos princípios da natureza humana que levaram a essas filosofias distorcidas e, desse modo, pode revelar fatores importantes que nosso autor deverá levar em conta quando for estabelecer sua concepção da verdadeira filosofia.

Passemos, então, à análise do modo como Hume trata a questão da falsa filosofia na seção sobre a filosofia antiga. Antes de qualquer outra coisa, talvez seja interessante mostrarmos a passagem desse texto em que nosso filósofo emprega essa expressão. 
Nela, Hume afirma que "podemos observar uma gradação de três opiniões, que se erguem umas sobre as outras, à medida em que as pessoas que as formam adquirem novos graus de razão e conhecimento. Essas opiniões são a do vulgo, a de uma falsa filosofia e a da verdadeira”32 (HUME 31, p. 147). Ora, dado o título da seção em que essa afirmação é feita, podemos supor que Hume chega a ela a partir da investigação de características particulares de conceitos aceitos por pensadores da antiguidade. É interessante, então, reconstituirmos as considerações que vemos nessa seção.

O propósito declarado da análise da filosofia antiga realizada por Hume é, como já dissemos, a investigação dos princípios da natureza humana. Segundo o autor, a crítica do que ele denomina algumas ficções engendradas pelos antigos, como, por exemplo, os conceitos de substância, o de acidente e o de qualidades ocultas, pode ser muito útil nesse sentido ${ }^{33}$. Isso porque essas invenções, por mais caprichosas que sejam, não apenas têm uma conexão muito íntima com os princípios da natureza humana como são produto direto dela. Para Hume, os conceitos elaborados pelos filósofos antigos nada mais são do que tentativas não de resolver, mas de ocultar certas contradições que surgem naturalmente em nossos pensamentos. Essas tais contradições são expressas nos seguintes termos:

\begin{abstract}
“A maioria dos filósofos mais judiciosos confessa que nossas idéias de corpos não são nada além de coleções formadas pela mente das idéias de várias qualidades sensíveis distintas, das quais os objetos são compostos, e que descobrimos que têm uma união constante umas com as outras. Mas independentemente de serem essas qualidades inteiramente distintas em si mesmas, é certo que comumente vemos o composto que elas formam como uma ÚNICA coisa, que continua a
\end{abstract}

\footnotetext{
32 " [...] we may observe a gradation of three opinions, that rise above each other, according as the persons, who form them, acquire new degrees of reason and knowledge. These opinions are that of the vulgar, that of a false philosophy and that of the true $[\ldots]$ ".

${ }^{33}$ Entretanto, como também já dissemos, não podemos, apenas porque o primeiro propósito de Hume é o estudo da natureza humana, perder de vista o fato de a falsa filosofia ser não apenas errônea, mas efetivamente perniciosa. Posteriormente, mostraremos ser esse um dos motivos pelos quais Hume trata as formas falsas de filosofia de maneira bastante agressiva.
} 
MESMA ainda que sofra alterações consideráveis ${ }^{34 \%}$.

(HUME 31, p.

145)

A filosofia antiga surge, então, como uma tentativa de ocultar mais uma contradição presente em nossa concepção daquilo a que chamamos objetos. Ao olharmos, por exemplo, uma mesa, temos a concepção de uma cor, uma textura, um formato e outras características semelhantes, mas, no fim das contas, ainda que essas qualidades sejam distintas umas das outras (e elas certamente são, ou não seríamos capazes nem mesmo de pensá-las separadamente), acabamos considerando que formam apenas um objeto, idêntico a si mesmo, que denominamos mesa. Ora, estamos lidando com um composto, o que é contrário à ideia de simplicidade. Além disso, a contradição ocorre, para Hume, porque o fato de considerarmos que um objeto pode permanecer sendo ele mesmo ainda que sofra variações é contrário à ideia de identidade.

Nosso autor passará, então, a explicar as causas dessas contradições e, é claro, de que maneira elas engendraram muitos dos conceitos da filosofia antiga. Podemos dizer que o objetivo aqui não é tão diferente daquele que Hume se havia proposto em “Do Ceticismo com relação aos Sentidos”: ele se põe a mostrar os princípios da natureza humana que geraram as contradições de que trata agora e, como não poderia deixar de ser, de que modo esses mesmos princípios estão na raiz do erro de uma certa maneira de filosofar. Logo de início, fica bastante claro que o erro da imaginação que faz com que atribuamos identidade a percepções muito semelhantes, mesmo depois de uma interrupção, guarda certas semelhanças com aquele que gera a contradição de que falamos agora. Isso porque, “já que idéias das várias qualidades distintas e sucessivas dos objetos são unidas por uma relação muito próxima, a mente, ao contemplar a sucessão, deve ser levada de uma parte dela a outra por uma transição fácil, e não perceberá a mudança mais do que se contemplasse o mesmo objeto imutável. Essa transição fácil é o efeito, ou, antes, a essência da relação ${ }^{35 ”}$ (HUME 31, p. 145). De

\footnotetext{
34 “'Tis confest by the most judicious philosophers, that our ideas of bodies are nothing but collections form'd by the mind of the ideas of the several distinct sensible qualities, of which objects are compos'd, and which we find to have a constant union with each other. But however these qualities may in themselves be entirely distinct, 'tis certain we commonly regard the compound, which they form, as ONE thing, and as continuing the SAME under very considerable alterations".

35 “[...] It is evident that as the ideas of the several distinct successive qualities of objects are united together by a very close relation, the mind, in looking along the succession, must be carried from one part
} 
certa maneira, o que Hume diz nessa passagem é que a relação de contiguidade também confunde a imaginação, a exemplo do que já acontecia com a de semelhança. Se concebemos várias qualidades contíguas como um só objeto é porque a mente, ao fazer a transição entre elas todas de maneira bastante suave, acaba por não se dar conta da mudança. É isso que faz com que a mente considere essas várias qualidades como se fossem uma só coisa.

Esse efeito sobre a imaginação pode ser resultado, também, da contiguidade no tempo. Para mostrar isso, Hume emprega com a relação de contiguidade um procedimento que já havia usado, na seção sobre os sentidos para fazer observações sobre a associação por semelhança. Pede que consideremos as diferenças entre um objeto seguido ao longo de várias mudanças graduais sofridas por ele e outro que, ao ser observado pela segunda vez, já sofreu variações bastante consideráveis. É evidente que o primeiro caso, por permitir uma transição bastante suave da imaginação entre as várias percepções, preservará, ainda, aquilo a que chamamos identidade. O segundo caso, porém, nos dará a ideia de diversidade. Mais uma vez, então, encontramo-nos em situação bastante contraditória $^{36}$. A razão não permite que consideremos qualquer objeto como dotado de simplicidade, é como simples que a imaginação nos leva a considerá-lo. Do mesmo modo, a razão não considera, digamos, que uma certa porção de lenha é a mesma em dois momentos consecutivos de um período em que está sendo consumida pelo fogo. Já a imaginação, como sabemos, arrasta-nos para o outro lado, fazendo com que tendamos a crer tratar-se da mesma porção de lenha, de algo dotado de identidade. E para resolver essas contradições, a imaginação, mais uma vez, finge a existência de algo como um princípio de união que une as qualidades do objeto e incorpora, também, as variações graduais que ele porventura sofra.

Segundo Hume, foi daí que os filósofos peripatéticos extraíram a noção de substância e acidente. Para nosso autor, os antigos atribuiriam a tudo que existe a mesma substância. As diferenças entre os vários objetos, como água, terra, fogo e ar, dever-se-iam ao fato de terem formas substanciais diferentes. Seria, por assim dizer, uma questão de ponto de vista: quando queremos afirmar semelhanças entre objetos,

of it to another by an easy transition, and will no more perceive the change than if it contemplated the same unchangeable object. This easy transition is the effect, or rather essence of relation [...]”.

${ }^{36}$ Cf. HUME 31, pp. 145-6. 
dizemos que têm a mesma substância. Quando atentamos às diferenças entre eles, afirmamos que têm formas diferentes. A noção de acidente, por sua vez, decorre como que necessariamente desse modo de pensar. Ora, é impossível, uma vez aceita a noção de substância, que acreditemos que qualidades como cor, gosto e outras propriedades desse tipo possam subsistir sem objetos dotados de substância para sustentá-las. O costume de imaginar essa dependência tem o mesmo resultado que teria observá-la. É por isso que, apesar de ser evidente que qualquer qualidade pode ser concebida à parte, os peripatéticos não hesitam em afirmar "seus sentimentos que dizem respeito a qualidades ocultas, e supõe tanto uma substância que sustenta, a qual eles não entendem, e um acidente que é sustentado, do qual eles têm uma idéia igualmente imperfeita. O sistema todo é, portanto, igualmente incompreensível, e, ainda assim, é derivado de princípios tão naturais quanto qualquer um dos que foram explicados anteriormente $^{37,}$ (HUME 31, p. 147). Em outras palavras, o que ocorre, aqui, é semelhante àquilo que pudemos observar com relação à doutrina da dupla existência. $\mathrm{O}$ vulgo, evidentemente, não pensa o mundo em termos de substância, formas e acidentes. Simplesmente pressupõe entre as qualidades dos objetos aquela união que não tem como deixar de sentir. Os filósofos, por sua vez, percebem esse erro cometido pelas pessoas comuns, na medida em que o mínimo uso da razão revela que as qualidades que concebemos unidas e, assim, "transformamos" em objetos podem ser concebidas separadamente e, portanto, independente de aceitarmos qualquer justificação metafísica estabelecida por pensadores, podem ser consideradas como passíveis de existir separadas. Puseram-se, então, a procurar incansavelmente as conexões entre as várias qualidades dos objetos. Foram, porém, completamente incapazes de aceitar que as associações entre as qualidades dos objetos acontecem apenas na mente e, no fim das contas, a única coisa que nos leva a considerar que essas qualidades estão associadas de algum modo é o hábito, que nos faz sentir essa conjunção de maneira mais forte e vivaz.

Hume considera, então, que os falsos filósofos são dotados de um gênio forte o bastante para libertar-se dos preconceitos do vulgo, segundo os quais há uma conexão natural e perceptível entre as várias qualidades sensíveis e ações dos objetos percebidos, mas não

\footnotetext{
37 “[...] their sentiments concerning occult qualities, and both suppose a substance supporting, which they do not understand, and an accident supported, of which they have as imperfect an idea. The whole system, therefore, is entirely incomprehensible, and yet is derived from principles as natural as any of these above explained".
} 
conseguem deixar de buscar para sempre essa conexão na matéria ou em causas externas à mente. É uma busca que Hume considera condenada ao fracasso, como as de Sísifo e Tântalo: os falsos filósofos buscam avidamente algo que sempre lhes escapará, ou então algo que simplesmente não está onde procuram. Se conseguissem chegar às conclusões corretas, simplesmente adotariam mais uma vez postura semelhante à do vulgo, que simplesmente se mantém indiferente a todas essas reflexões. Essa, como sabemos, seria a posição do verdadeiro filósofo, que, ao perceber que o tema das chamadas qualidades ocultas simplesmente está fora de seu alcance, trata de permanecer indiferente a ele. Sua posição não é exatamente a do vulgo, já que sua indiferença vem não de uma simples aceitação inicial do que nos é imposto pela natureza ou da indolência. O que acontece é que o verdadeiro filósofo, depois de longos e rigorosos estudos, descobre com certeza o que pode ou não conhecer, e passa a não se desesperar com questões que, como já dissemos, estão além de seu alcance ${ }^{38}$.

Ao considerar a coisa dessa maneira, Hume conclui que noções como faculdade e qualidade oculta são como que um consolo oferecido pela natureza aos filósofos que acreditam nelas, algo que os preserva do enorme desapontamento que os acometeria se fossem obrigados a encarar a frustração inevitável que deveria suceder suas buscas. E esses pensadores devem tal consolo a um princípio da natureza humana que faz com que, depois de repetir muitas vezes qualquer palavra, tendamos a omitir a ideia que ela representa e preservar apenas o costume pelo qual trazemos a ideia, que, no caso, identifica-se à própria palavra, à mente. Isso permite que, ao usar freqüentemente uma palavra completamente desprovida de qualquer sentido, o filósofo por meio do costume, trate-as como se fossem como as outras palavras, as que têm sentido. “A semelhança de sua aparência engana a mente, como de hábito, e faz com que imaginemos uma forte semelhança e uma forte conformidade ${ }^{39}$ ” (HUME 31, p. 148). É assim, diz Hume, que esses filósofos se tranquilizam, chegando, por meio dessa ilusão, à mesma indiferença

\footnotetext{
${ }^{38}$ Cf. HUME 31, p. 147.

39 "The resemblance of their appearance deceives the mind, as is usual, and makes us imagine a thorough resemblance and conformity".
} 
que "as pessoas atingem por sua estupidez, e os verdadeiros filósofos, por seu ceticismo moderado $^{40,}$ (HUME 31, p. 148).

Poderíamos aproveitar o final de nossa análise sobre a seção "Da Filosofia Antiga” para tecer mais algumas considerações sobre a concepção humiana da falsa filosofia, já que alguns elementos que Hume já deixara claro ao tratar do ceticismo com relação aos sentidos ficaram, aqui, ainda mais evidentes. Entretanto, a crítica de nosso autor à filosofia antiga adentra a seção seguinte, intitulada “Da Filosofia Moderna”. Além disso, essa seção forma, como já dissemos, algo como um “bloco unificado” com as duas que a precedem, de modo que pode ser interessante nos dedicarmos a ela e, em seguida, verificarmos o que é possível extrair sobre a falsa filosofia do conjunto formado pelas três seções.

Vejamos, então, de que maneira a seção sobre a filosofia moderna é iniciada. Nas primeiras linhas, Hume trata de arrematar as críticas que fizera à filosofia antiga. Para isso, antecipa uma objeção segundo a qual, como ele mesmo admite considerar a imaginação como o juiz definitivo em sua filosofia, seria no mínimo curioso ele criticar outras maneiras de filosofar se o grande “pecado" cometido por elas é apenas também se deixar levar por essa faculdade ${ }^{41}$. Para escapar a essa armadilha, Hume estabelece uma distinção entre dois sentidos de imaginação. O primeiro deles é o que inclui princípios que nosso autor considera permanentes, irresistíveis e universais, como, por exemplo, a transição de causas a efeitos ocasionada pelo hábito. O segundo é aquele em que a imaginação é guiada por princípios mutáveis, fracos e irregulares ${ }^{42}$. $\mathrm{O}$ que $\mathrm{o}$ filósofo pretende com isso não é afirmar que existem, por assim dizer, dois tipos de

40 “[...] the people attain by their stupidity, and true philosophers by their moderate scepticism”.

${ }^{41}$ É importante lembrarmos, nesse ponto, que as associações de semelhança, contiguidade e causa e efeito, em que Hume baseia toda a sua teoria do conhecimento, também são, para ele, parte da imaginação.

${ }^{42}$ Em seu Hume, Jean-Pierre Cléro observa que é precisamente essa distinção entre princípios mais constantes e outros mais fracos e mutáveis que distingue o sentido aceito por Hume de razão daquilo que ele chama imaginação. A razão seria algo como uma forma específica da imaginação, e se diferenciaria de manifestações mais fantasiosas desta por sua maior regularidade e pelo recurso constante e rigoroso à experiência passada. No Capítulo III, trataremos com mais detalhes dos modos de raciocínio que nosso autor considera efetivamente válidos. 
imaginação. Não estamos falando, aqui, de duas faculdades distintas. O que acontece é que o termo "imaginação" inclui, na filosofia humiana, uma gama demasiadamente vasta de processos, sendo que apenas alguns deles, os que Hume elencou na primeira das duas “categorias” que acabamos de mencionar, são tidos por ele como válidos quando se trata de fazer ciência.

De qualquer maneira, segundo o nosso autor, foi exatamente com o objetivo de eliminar para todo o sempre os "espectros" deixados pelos pensadores antigos que a filosofia moderna surgiu. Evidentemente, ela se pretende livre dos problemas que teriam acometido sua, digamos, antecessora. Seu princípio fundamental é apresentado por Hume como sendo uma "opinião no que diz respeito a cores, sons, gostos, odores, calor e frio, os quais ela considera que não são nada além de impressões na mente, derivadas da operação de objetos externos, e desprovidas de qualquer semelhança com as qualidades dos objetos ${ }^{43}$ " (HUME 31, p. 149). Hume considera que apenas uma das razões que teriam colaborado para o surgimento dessa opinião pode ser considerada satisfatória: as mudanças constantes por que passam as qualidades dos vários objetos, mesmo quando estes, em função do mecanismo explicado na seção sobre a filosofia antiga, continuam a ser considerados os mesmos. Um exemplo seria, por exemplo, a variação nas sensações produzidas pelo fogo conforme a distância a que nos encontramos dele. Essas variações evidentemente teriam como conseqüência a conclusão de que as referidas qualidades não são inerentes ao próprio objeto: parece inegável que um mesmo objeto não pode possuir duas qualidades referentes ao mesmo sentido, como, por exemplo, calor e frio, ou dois graus diferentes de calor. Além disso, é impossível que a mesma qualidade produza duas impressões completamente diferentes uma da outra. Portanto, qualidades como cor, som e outras do tipo, não podendo ter sua origem nos próprios objetos externos, devem ser remetidas a outra fonte. Para os filósofos modernos de que Hume trata na Seção 4 da Parte 4 do Livro 1 do Tratado, essa outra fonte é a própria mente.

\footnotetext{
43 “[...] opinion concerning colours, sounds, tastes, smells, heat and cold; which it asserts to be nothing but impressions in the mind, deriv'd from the operation of external objects, and without any resemblance to the qualities of the objects.” .
} 
Preparado o terreno, nosso autor volta suas baterias impiedosamente contra essa doutrina. Depois de expor os princípios que mencionamos no parágrafo anterior, ele afirma que a concordância com eles ocasiona a queda irrefreável de todas as doutrinas da filosofia moderna. Isso porque considerando cores, sons, calor, frio e outras qualidades desse tipo como existentes não apenas nos próprios objetos, mas na mente, as únicas características que os filósofos afirmam que podemos considerar que existem nos próprios objetos exteriores são aquelas que a modernidade, a partir de Galileu, denominou qualidades primárias ${ }^{44}$. Estas, como sabemos, resumem-se a duas: extensão e solidez, com suas diferentes misturas e modificações, entre as quais Hume inclui figura, movimento, gravidade e coesão. Fenômenos como geração, aumento e corrupção de animais e vegetais seriam apenas mudanças de figura e movimento, bem como quaisquer operações de um corpo sobre outro. Até aí, nada de novo. Essa era uma posição que não constituiria motivo de escândalo para qualquer filósofo moderno. Logo em seguida, porém, Hume expõe uma posição bastante, por assim dizer, incomum à época: a de que a doutrina das qualidades primárias e secundárias, longe de explicar as operações dos objetos externos, simplesmente nos põe em uma situação em que não temos como atribuir a eles qualquer coisa parecida com uma existência real. "Se cores, sons, gostos e aromas são meramente percepções, nada que podemos conceber possui uma existência real, contínua e independente; nem mesmo o movimento, a extensão e a solidez, que são as qualidades primárias em que mais se insiste ${ }^{45 ”}$ (HUME 31, p. 150).

Fica bastante claro, então, o rumo que a investigação de nosso autor acerca da filosofia moderna tomará: seu objetivo, como já está mais do que evidente, é minar a doutrina das qualidades primárias e secundárias, mostrando que, a partir do momento em que aceitamos que toda investigação sobre temas desse tipo deve partir de nossas percepções, é impossível que as qualidades primárias possam ser vistas como algo que pode existir fora de nossas mentes. É com o objetivo de fortalecer essa ideia que ele se põe a analisar, logo a seguir, a ideia de movimento. Este, para ele, só pode ser entendido como a idéia de um objeto se movendo. Essa idéia, então, deve obrigatoriamente poder

\footnotetext{
${ }^{44}$ Cf. HUME 31, p. 150.

45 "If colours, sounds, tastes, smells be merely perceptions, nothing we can conceive is possest of a real, continu'd, and independent existence; not even motion, extension and solidity, which are primary qualities chiefly insisted on".
} 
ser reduzida àquelas de extensão e solidez se quisermos que o movimento possa ser algo que tem uma existência contínua e independente. A extensão, por sua vez, só pode ser concebida como algo composto de partes, as quais são dotadas de cor e solidez. A idéia de extensão é, portanto, uma idéia composta, que pode ser reduzida a idéias simples e indivisíveis, que, por sua vez, não são idéias de extensão ${ }^{46}$, e, portanto, devem ser concebidas como coloridas ou como sólidas ${ }^{47}$. Ora, a cor, como qualquer um que defenda a doutrina das qualidades primárias e secundárias aceitará prontamente, não tem existência real. É preciso, então, que a idéia de extensão possa ser reduzida à de solidez.

Resta, então, observar em que consiste a idéia de solidez. Hume a define como sendo a idéia de "dois objetos, que, ao serem impelidos pela maior força, não podem

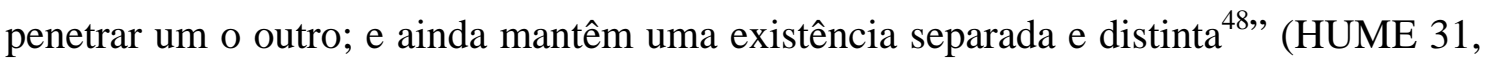
p. 150). Desse modo, não é difícil concluir que a solidez é completamente impossível de ser compreendida em si mesma, sem que concebamos corpos sólidos que mantenham essa existência independente. Ocorre, porém, que não temos como conceber esses corpos sem incluir, em nossas concepções, idéias como cores, sons e outras qualidades secundárias. Ora, como já vimos, a idéia de movimento depende da de extensão, que, por sua vez, depende da de solidez. Esta, portanto, não pode depender de qualquer uma das duas anteriores, ou incorreríamos em um círculo vicioso. "Nossa filosofia moderna, portanto, não nos deixa nenhuma idéia justa ou satisfatória de solidez, e nem,

\footnotetext{
${ }^{46} \mathrm{O}$ motivo pelo qual as ideias que compõem aquela de extensão não podem ser elas mesmas ideias de extensão parece suficientemente claro, mas talvez não seja de todo inoportuno explicar. Se Hume aceitasse essa solução, estaria aceitando que o definido constasse da definição. Em outras palavras, estaria usando, para explicar uma determinada ideia, ela própria. É óbvio, portanto, que as ideias “concebidas como coloridas ou sólidas” a que ele se refere não podem de maneira alguma ser, elas mesmas, ideias de extensão.

${ }^{47}$ Nesse ponto, Hume reconstitui, de maneira bastante breve, argumentos apresentados nas seções em que ele discute a idéia de espaço, na Parte 2 do Livro 1 do Tratado.

48 " [...] two objects, which being impell'd by the utmost force, cannot penetrate each other; but still maintain a separate and distinct existence”.
} 
conseqüentemente, de matéria" $^{49, " ~(H U M E ~ 31, ~ 151) . ~ I s s o ~ p o r q u e, ~ c o m o ~ j a ́ ~ d e v e ~ t e r ~ f i c a d o ~}$ claro, não temos como conceber nenhum corpo sem recorrer às qualidades secundárias.

Aparentemente, o que foi dito nos parágrafos anteriores já bastaria para demolir a doutrina das qualidades primárias e secundárias. Esses não são, porém, os únicos argumentos empregados por Hume contra essa maneira de conceber os objetos. Ele tem, ainda, algumas outras objeções. A primeira delas decorre da afirmação de que a impenetrabilidade que caracteriza a solidez é, propriamente falando, a impossibilidade de aniquilação. Ora, compreender um conceito como esse exigiria que concebêssemos distintamente um objeto que não pudesse ser aniquilado; o que não é possível sem um recurso às qualidades secundárias.

Uma outra objeção empregada por nosso autor decorre do famoso método empregado por ele para verificar se uma idéia é ou não provida de sentido: tentar encontrar a impressão que a teria originado ${ }^{50}$. Esta deve ser uma impressão do tato, já que os outros sentidos não parecem apropriados para descobrir a impressão que seria responsável pela idéia de solidez. E é natural que imaginemos sentir a solidez dos corpos. Entretanto, esse método parece a Hume mais popular do que filosófico. Isso porque, em primeiro lugar, o sentimento é bastante diferente da própria solidez. Alguém que tenha perdido a sensibilidade em uma mão tem uma boa idéia da impenetrabilidade quando observa que sua mão é sustentada por uma mesa, por exemplo. Essa idéia não é menos clara do que a que ele tem ao sentir a mesa com a outra mão. Ainda que possamos sentir um objeto pressionado contra nossos corpos e a resistência, pelo movimento que imprime a nossos nervos, transmita-nos uma determinada sensação, não há como inferir que a sensação, o movimento e a resistência são semelhantes ou a mesma coisa. Em outras palavras, o fato de termos uma sensação não autoriza, por motivos que já devem ter ficado claros, que digamos que ela decorre de uma qualidade presente no próprio objeto. Em segundo lugar, as impressões do tato são impressões simples. Não podem, então, ser responsáveis por uma idéia composta, como necessariamente deve ser a de solidez, que supõe dois corpos, bem como

\footnotetext{
49 "Our modern philosophy, therefore, leaves us no just nor satisfactory idea of solidity; nor consequently of matter”.

${ }^{50}$ Ver a Seção 3 do Livro 1 do Tratado. Esse método para se verificar se uma idéia tem algum sentido real é reafirmado por Hume, também, na Seção 2 de sua Investigação sobre o Entendimento Humano.
} 
contigüidade e impulso. Além disso, a própria sensação não deve ser incluída na idéia de solidez. Isso porque a solidez, além de se aplicar também ao que não sentimos no presente, deve ser constante, ao passo que as impressões que nos são fornecidas pelo tato variam a cada instante.

As conclusões que Hume expõe ao fim dessa seção não fogem de maneira alguma ao que poderíamos esperar. A doutrina das qualidades primárias e secundárias é colocada como uma tentativa, por parte dos modernos, de ocultar mais uma dessas contradições que são inerentes à maneira como a natureza humana lida com um suposto mundo exterior. Mais especificamente, a contradição se dá, como de hábito, entre o que a razão nos permite descobrir e uma outra tendência, aquela que nos é imposta pelos sentidos e pela imaginação. Ocorre, porém, que a doutrina das qualidades primárias e secundárias, que nosso autor percebe como ao menos parte do que caracterizaria a filosofia moderna, não resiste a um escrutínio mais detalhado. Desse modo, está sujeita aos mesmos problemas que já havíamos percebido no caso das doutrinas antigas.

Tendo examinado com algum detalhamento isso que chamamos o "bloco" composto pelas seções sobre os sentidos, sobre a filosofia antiga e sobre a filosofia moderna, podemos nos dedicar, por alguns instantes, a um exame do que esses textos nos permitem descobrir sobre a concepção humiana da falsa filosofia, e de sua origem de acordo com certos princípios da natureza humana. Em primeiro lugar, devemos ter em mente que, ao longo das três seções que acabamos de analisar, o alvo de Hume não parece ser o modo como o vulgo concebe o mundo exterior. Ainda que as pessoas comuns acreditem em ficções da imaginação, os textos que vimos não parecem fazer uma reprimenda a elas por conta disso. É verdade que o vulgo dá seu assentimento a concepções que não resistem a um exame mais rigoroso, mas o caso é que essas crenças são, como já vimos, aquelas a que todos, por mais filósofos que sejam, dão sua anuência em boa parte do tempo. Por mais que filósofos de todos os tipos possam sustentar posições que entram em conflito com elas, parece que fora de seus gabinetes, quando têm que interagir com o mundo que percebem em conjunto com os outros homens, eles fazem mais do que simplesmente aceitar o modo comum de falar sobre o mundo: parece que, teorias à parte, todos acreditam, em suas vidas cotidianas, na existência contínua dos objetos que percebem como exteriores. Além disso, aceitam que, mesmo que sofram algumas variações, esses objetos conservam sua identidade. O vulgo 
simplesmente não sente necessidade alguma de explicar essa crença, que passa por evidente.

Também não podemos perder de vista o fato de Hume atribuir essas ficções da imaginação, bem como as contradições que elas estabelecem com princípios mais racionais, não a algum erro teórico crasso, mas à própria natureza humana. $\mathrm{O}$ vulgo, como acabamos de afirmar, não é visto de modo algum como uma instância que estabelece teorias mirabolantes sobre o mundo exterior. Na verdade, Hume vê a postura das pessoas comuns como sendo a de ignorância acerca das contradições percebidas pelos filósofos. Não é o homem comum que busca uma teoria de qualidades ocultas para explicar de que modo ele passa a considerar uma série de percepções contíguas como um mesmo objeto, ou que aceita a teoria da dupla existência. Como já vimos, o vulgo parece contente em tratar suas percepções como se fossem o próprio mundo e, se é verdade que trata suas percepções como pertencentes a um mundo por ele considerado como exterior, também é verdade que, por outro lado, concorda com o verdadeiro filósofo por acreditar que não temos acesso a nada senão ao mundo percebido. Assim, não parece nada despropositado afirmar que, ainda que Hume perceba claramente que as opiniões do vulgo estão calcadas o tempo todo em ficções, isso não é algo que ele vê como censurável. Essas ficções, afinal, não são convertidas pelos homens comuns em afirmações filosóficas que parecem buscar uma suposta verdade última sobre o mundo exterior. Têm, antes, a condição de crenças aceitas simplesmente porque aqueles que as mantêm não se dispuseram a raciocinar a respeito das causas primeiras de suas percepções.

Não podemos, é claro, dizer o mesmo dos filósofos que foram responsáveis por doutrinas como a dupla existência, as qualidades ocultas e as qualidades primárias e secundárias. Até o leitor mais descuidado, a esta altura, já percebeu que é contra eles que Hume volta suas baterias nas seções que analisamos aqui. Devemos, então, tentar fazer algumas observações sobre os motivos pelos quais nosso autor considera condenáveis os sistemas filosóficos acerca do mundo exterior. E como não poderia deixar de ser, não podemos, de maneira alguma, acreditar que o único erro que Hume atribui a esses filósofos é o fato de terem procurado estabelecer a própria existência de um mundo exterior. Ainda que esse seja inevitavelmente um erro cometido por 
praticamente toda a tradição que nosso autor critica, é apenas um erro ${ }^{51}$. E ainda que Hume faça questão de apontar, ao longo de sua obra, uma série de erros cometidos por seus predecessores, não parece ser isso o que determina o que é a boa ou a má filosofia $^{52}$. Os problemas que contribuem para o estabelecimento de algumas filosofias como falsas, até aqui, são de natureza mais grave.

Em primeiro lugar, como já observamos algumas vezes, os filósofos criticados por Hume constroem seus sistemas como uma tentativa de solucionar uma contradição. Esse fator, considerado em si mesmo, não é algo ruim. O grande problema é que, a partir do reconhecimento dessa contradição, eles não são capazes de ir tão longe quanto deveriam. Em outras palavras, ao aplicarem sua razão à análise das opiniões aceitas pelo vulgo, as rejeitam completamente e, em seguida, criam sistemas que não conseguem oferecer uma explicação que realmente desfaça a contradição. O que acontece é que ela ainda está presente, e tudo que os sistemas oferecidos pelos falsos filósofos permitem é que transitemos constantemente entre as opiniões do vulgo e aquelas defendidas por uma suposta razão. Aliás, os sistemas esposados pelos falsos filósofos nem mesmo podem, segundo Hume, ser considerados verdadeiramente racionais. A argumentação apresentada por nosso autor nas seções que tratamos de observar aqui tem justamente o propósito de mostrar que a razão não é suficiente para estabelecer nenhuma das doutrinas que ele criticou. Assim, as falsas filosofias, além de não colaborarem em nada

\footnotetext{
${ }^{51}$ Se dizemos que Hume vê aí um erro cometido pelos filósofos, não é porque defendemos que ele negaria terminantemente a existência de algo como um mundo exterior. O caso é que, ao menos nos textos de que tratamos agora, Hume não parece aceitar a possibilidade de se provar a existência de algo desse tipo. Por outro lado, não podemos deixar de notar que esses textos não permitem que concluamos pela não existência de um mundo exterior. Essa indecisão, tanto na Parte 4 do Livro 1 do Tratado quanto em outros momentos da obra de Hume, tem sido causa de um grande debate entre aqueles que defendem o "velho Hume", ou seja, uma leitura segundo a qual nosso autor seria um cético quanto à existência do mundo exterior, e aqueles que defendem o que tem sido chamado o "novo Hume", e que consideram que ele vê boas razões epistemológicas para acreditarmos na existência do mundo exterior, ainda que não possamos dizer muito sobre ele. No Capítulo III, ao tratarmos da concepção humiana da verdadeira filosofia, trataremos desse tema de modo muito mais detalhado.

${ }^{52}$ Isso fica bastante claro quando atentamos para as (por assim dizer) correções que Hume faz, por exemplo, a Shaftesbury (por exemplo, no que diz respeito à identidade pessoal, entre outros aspectos). Ainda que discorde desse autor em boa parte do tempo, Hume não o critica direta e especificamente por conta de sua maneira de filosofar.
} 
para resolver as contradições que percebem, não são tão racionais quanto seus defensores gostariam de fazer parecer que são. E esse resultado altamente indesejável é obtido às custas do sacrifício das opiniões do senso comum que, apesar de originárias de uma ficção, ao menos não criam uma série de problemas adicionais que se mostram completamente insolúveis. Mais ainda, não falamos, aqui, simplesmente do sacrifício de uma instância completamente estúpida em favor de uma ficção. Hume deixa claro, na seção “Da Filosofia Antiga”, que a posição do vulgo está mais próxima da do verdadeiro filósofo do que aquela defendida pelas falsas filosofias, ainda que o vulgo aceite as percepções como as únicas coisas a que tem acesso por conta de sua indolência, enquanto o verdadeiro filósofo chega ao mesmo resultado depois de descartar os princípios defendidos pelos falsos filósofos.

No próximo capítulo, veremos que as formas de filosofia moral consideradas por Hume como falsas não necessariamente se iniciam como a tentativa de resolver uma contradição, mas elas têm, todas, como as analisadas aqui, a característica de rejeitar, mesmo sem bases consistentes, aquilo que é aceito comumente pelo vulgo. Parece seguro afirmar que essa rejeição contumaz é uma das características mais marcantes da atividade filosófica em suas formas falsas. Ao perceber problemas nas crenças aceitas pelos homens comuns, o falso filósofo invariavelmente rejeita todo o sistema de crenças do vulgo e busca substituí-lo por seu sistema preferido. Na Conclusão do Livro 1 do Tratado, da qual trataremos posteriormente, não apenas isso ficará ainda mais claro, como Hume tratará de deixar clara sua completa rejeição de uma filosofia que fuja completamente aos dados impostos pela vida comum. Além de propor que o filósofo não abra mão da vida social, e que exerça sua filosofia sempre assentado em propensões naturais, nosso autor afirma que gostaria de poder comunicar aos fundadores de sistemas "uma parcela dessa mistura terrena grosseira, como um ingrediente que comumente lhes faz muita falta, e que serviria para temperar essas partículas

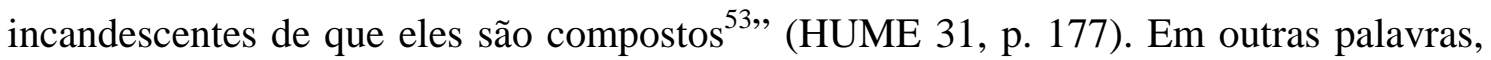
ficará mais claro que a filosofia humiana aceitará certos pressupostos que também estão presentes nas opiniões do vulgo. O falso filósofo, por seu lado, simplesmente cria princípios totalmente novos e busca explicar a partir deles um mundo que simplesmente

\footnotetext{
53 “[...] a share of this Gross earthy mixture, as an ingredient, which they commonly stand much in need of, and which wou'd serve to temper those fiery particles, of which they are compos'd”.
} 
não é o mundo que ele compartilha com todos os outros homens. Já deixamos bastante claro o modo como isso acontece, por exemplo, no caso das várias doutrinas referentes à existência de objetos externos.

Devemos, portanto, observar que o fato de o falso filósofo criar princípios inteiramente novos e distintos daqueles aceitos pelo vulgo é algo que vem acompanhado de um pequeno problema: esses princípios dizem respeito a entidades que são reconhecidas pela atividade filosófica em suas formas falsas como entidades existentes no mundo. Aqueles que defendem a doutrina da dupla existência realmente acreditam, para Hume, na existência de objetos externos que causam nossas percepções. Do mesmo modo, o filósofo antigo realmente acredita na existência de qualidades ocultas. O filósofo moderno, por sua vez, não defende a teoria das qualidades primárias e secundárias apenas porque esta lhe parece um modelo explicativo razoável, mas sim por crer efetivamente que os objetos externos existem segundo essa tese. Com isso, parece razoável afirmarmos que a falsa filosofia cria ficções que não se referem ao mundo tal como ele é percebido por todos. O que Hume parece afirmar é que os falsos filósofos, longe de conseguir explicar o mundo tal como ele parece ser para todos os outros homens, criam um universo à parte e, desse modo, só o que podem explicar é o funcionamento deste ${ }^{54}$. E isso não acontece apenas quando os falsos filósofos tentam ${ }^{54}$ Tanto em seu Philosophical Melancholy and Delirium quanto no artigo "Hume on the Natural History
of Philosophical Consciousness”, Donald Livingston emprega a expressão "princípio de autonomia” para
se referir a esse aspecto das formas filosóficas que Hume considera falsas. Ainda que Livingston tenha
acertado ao afirmar que os falsos filósofos pretendem que suas filosofias sejam independentes do mundo
tido como real pelas pessoas comuns, parece-nos que esse comentador cometeu um grande exagero ao
chamar essa característica de princípio. Ora, ao longo dos textos a que nos referimos, parece que ela não
têm esse estatuto no sentido filosófico. Se assim fosse, teríamos de afirmar que, segundo Livingston, os
falsos filósofos conscientemente escolhem estabelecer uma teoria completamente descolada do mundo, e
esse não parece ser o caso. Como vimos, o esforço de Hume é justamente no sentido de mostrar de que
modo uma teoria que se pretende uma explicação do mundo se torna completamente descolada de seu
objeto, a ponto de não ser nada além de uma ficção, por assim dizer, megalomaníaca. Um outro princípio
a que se refere Livingston, o do ultimidade (aquele segundo o qual as falsas filosofias tentam entender as
coisas tais como são definitivamente, em sua instância última e definitiva), talvez possa ter efetivamente
esse status. Isso faz sentido se considerarmos que esse princípio decorre de uma concepção de razão
segundo a qual ela é capaz de conhecer plenamente todas as coisas (ou, dependendo da época e do falso
filósofo, todas aquelas que podem ser conhecidas), e essa própria concepção de razão é um alvo contra o
qual Hume dispara frequentemente e sem misericórdia. Ainda assim, devemos observar que Hume não
parece fazer consideraç̃es sobre a ultimidade enquanto princípio filosófico, apenas criticar a concepção 
explicar o mundo exterior, já que os princípios da natureza humana que os levam a considerar de uma certa maneira os objetos externos acabam se aplicando, também, à concepção que fazem da própria natureza humana. Isso fica evidente, por exemplo, na seção intitulada “Da Identidade Pessoal”. Vejamos, então, de que modo essa questão é conduzia por Hume. Isso nos permitirá reforçar o que já foi estabelecido até aqui sobre a concepção humiana da falsa filosofia e, além disso, mostrará de que maneira nosso autor, apesar de não nomear seus adversários, parte dessa concepção para criticar certas filosofias em particular.

\section{A identidade pessoal e as filosofias do sujeito}

Como havíamos adiantado, aquilo a que chamamos o "eu” (self) não pode ser para Hume, do ponto de vista do mero entendimento, mais que um feixe de percepções. É claro, portanto, que ele tratará de criticar os filósofos “que imaginam que estamos a todo momento intimamente conscientes do que chamamos nosso $\mathrm{EU}$, que sentimos sua existência contínua, e que estamos certos, mais do que seria possível pela evidência de

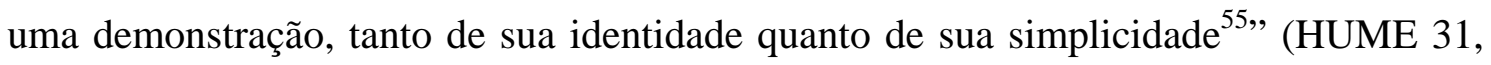
p. 164). Para nosso autor, as evidências de que realmente dispomos são contrárias a essa doutrina. Quando removemos todas as percepções que não podem ser consideradas aquela do eu, não resta absolutamente nenhuma. Como pode ser, então, que surja a crença segundo a qual nosso entendimento é capaz de chegar a uma noção clara de identidade pessoal?

de razão que leva a teorias que se propõem como definitivas. Por fim, o que Livingston chama de “princípio de domínio”, por estar apoiado no de ultimidade, talvez possa ser, como também veremos no próximo capítulo, uma característica recorrente das falsas formas filosóficas, mas não é algo que o próprio Hume diria ser um princípio. No fim das contas, essas características elencadas por Livingston, ainda que possam ser úteis e didáticas enquanto chave de leitura, não têm, nos textos de Hume, o estatuto que esse comentador confere a elas. Talvez fosse mais proveitoso que Livingston, em vez de simplesmente elencar princípios para guiar o leitor, tivesse feito uma análise mais próxima dos textos do próprio Hume para mostrar de que modo essas características são desenvolvidas por ele.

55 ، [...] imagine we are every moment intimately conscious of what we call our SELF; that we feel its existence and its continuance in existence; and are certain, beyond the evidence of a demonstration, both of its perfect identity and simplicity”. 
Uma parte da resposta a essa questão já havia sido dada na seção sobre a filosofia antiga: atribuímos uma identidade à série de percepções que denominamos o eu porque a relação de causa e efeito faz com que a transição de uma ideia à outra em nossas mentes seja suave. Desse modo, as variações sempre bastante graduais que percebemos no fluxo de nossas percepções permitem que confundamos umas com as outras, em um procedimento bastante semelhante àquele pelo qual somos levados a considerar uma série de percepções contíguas como um único objeto. É importante destacarmos, aqui, o papel da memória, que sem dúvida contribui em grande parte para a possibilidade do estabelecimento de relações de causa e efeito. Além disso, a relação de semelhança também contribui bastante para o estabelecimento da noção de identidade pessoal, já que ela, também por meio da memória, faz com que certas percepções sejam inseridas de maneira recorrente em nossa cadeia de pensamentos, o que facilita a transição de um elo a outro ${ }^{56}$.

Hume fornece, ainda, outros argumentos que ajudam a explicar o surgimento da noção de identidade pessoal. Um deles é o fato de haver uma semelhança entre o fluxo de ideias que compõe a mente e objetos em que há uma colaboração das partes para, digamos, um fim. É o caso, por exemplo, de um navio, que pode até ser reformado sucessivas vezes, até que não haja nenhuma parte que estava originalmente nele, mas continua sendo considerado o mesmo navio. Outro fator é a tendência natural que temos para confundir a identidade numérica e a específica. Por exemplo, se uma igreja passa por enormes avarias e tem que ser completamente reconstruída, continuamos a considerá-la a mesma igreja. Nesse caso, o processo é facilitado pelo fato de nunca termos nos deparado, no mesmo momento, com os dois objetos ao mesmo tempo. Por fim, a mente parece ser, como um rio, um objeto do tipo que é sempre o mesmo, ainda que suas partes mudem constantemente. O fluxo de nossas percepções, então, seria como as águas que não param de correr. Estas não param nunca e podemos dizer que qualquer rio que estejamos observando tem todas as suas partículas substituídas em menos de vinte e quatro horas. Ainda assim, ele é tido por qualquer um como sendo o mesmo rio. O caso é exatamente o mesmo com nossas mentes.

A conclusão óbvia é, portanto, que as filosofias que aceitam a identidade pessoal tal como ela é considerada tradicionalmente são, como aquelas que apregoam a

\footnotetext{
${ }^{56}$ Os argumentos a que nos referimos aqui podem ser encontrados em HUME 31, pp. 167-170.
} 
existência de qualidades ocultas, o resultado de uma ficção. Mais uma vez, podemos dizer com toda a segurança que o alvo de Hume não são as pessoas comuns que acreditam que temos uma identidade. Ainda que não esteja aparente, na seção sobre a identidade pessoal, uma grande preocupação em separar as posições da falsa filosofia daquelas comumente encontradas no vulgo, o alvo escolhido por Hume é designado logo no início do texto, quando ele afirma que dialogará com os filósofos segundos os quais estamos conscientes o tempo todo de nosso eu. E o fato de ele tratar a questão da identidade pessoal nos mesmos termos em que havia tratado da doutrina das qualidades ocultas deixa transparecer, sem muita margem para dúvida, que podemos ver também aqui um ataque não apenas a uma crença comum na comunidade filosófica da época, mas a uma maneira mesma de filosofar. Ora, a ficção pela qual o filósofo é levado a crer na existência efetiva da identidade pessoal é exatamente do mesmo tipo da que teria ocasionado as várias ficções sobre a existência de objetos externos. Mais uma vez, temos uma contradição bastante evidente entre aquilo que somos levados a aceitar pela imaginação e aquilo que a razão nos revela. A noção de eu, portanto, é gerada do mesmo modo que as próprias ideias de objeto externo e de substância ${ }^{57}$.

Evidentemente, isso não quer dizer que planejamos desqualificar as várias pesquisas (algumas delas excelentes, por sinal) que se dedicaram a verificar de que modo Hume desenvolve, em sua teoria do conhecimento, a questão da identidade pessoal. O caso é que, além de tratar dessa questão, é claro que ele pretende, ao mesmo tempo, criticar um certo modelo de filosofia. O fato de ele afirmar que a questão da identidade pessoal se tornou "uma questão de importância tão grande em filosofia,

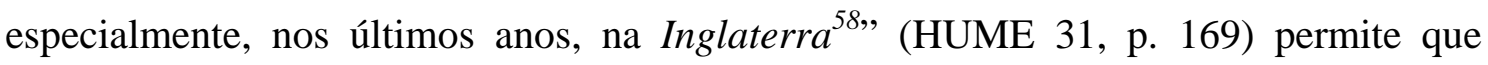

\footnotetext{
${ }^{57}$ Portanto, discordamos mais uma vez de Donald Livingston, para quem a seção sobre a identidade pessoal é diferente das outras da Parte 4 do Livro1 do Tratado por se a única delas em que a questão aparente, de primeira ordem (ou seja, a própria identidade pessoal) é realmente a mais importante, em detrimento daquela sobre a própria natureza da filosofia (Cf. Livingston 53, p. 14). Hume não perde de vista por um segundo, ao longo dessa seção, as falsas filosofias que busca desmascarar, e não parece se dedicar mais à identidade pessoal nessa seção do que se dedica, por exemplo, às qualidades ocultas na seção sobre a filosofia antiga.

58 “[...] so great a question in philosophy, especially of late years in England [...]”.
} 
imaginemos que ele pretende criticar, entre outros ${ }^{59}$, John Locke, para quem "nada pode ser mais evidente para nós do que nossa própria existência. Eu penso, eu sinto prazer e dor; poderá qualquer uma dessas proposições ser mais evidente para mim do que minha própria existência? Se eu duvidar de todas as outras coisas, essa própria dúvida fará com que eu perceba minha própria existência ${ }^{60 ”}$ (LOCKE 54, p. 547). Ora, essa é, como sabemos, a grande conclusão de Descartes em sua Segunda Meditação. É, também, uma conclusão que Hume trata de criticar no parágrafo 28 do Abstract, em que faz questão de criticar as doutrinas cartesianas segundo as quais "o pensamento seria a essência da mente” e a mente seria uma substância ${ }^{61}$. Ora, como já havia ficado bastante claro com a análise que fizemos da seção sobre a filosofia antiga, a ideia de substância não é considerada por Hume como nada além de uma ficção que ele pretende explicar para dar conta de certos princípios da natureza humana.

Parece, então, que nosso autor trabalha, na seção "Da Identidade Pessoal”, da mesma maneira que nas outras que analisamos neste capítulo. É justo, então, afirmarmos que, se elas propunham de maneira clara a questão de como os princípios da natureza humana originam as formas falsas da atividade filosófica, o mesmo acontece no tratamento da questão da identidade pessoal por Hume. Mais do que isso, essa seção se apoia sobre várias conclusões extraídas de outras a que já nos referimos e revela, como já deve ser óbvio, um modus operandi bastante similar. Mais uma vez, o que temos são de que a natureza humana não permite escapar, as quais geram teorias

\footnotetext{
${ }^{59}$ Como nos indica David Fate Norton nas notas à sua edição do Tratado, outros pensadores ingleses que Hume teria tido em vista são Shaftesbury, Clarke, Collins, Berkeley, Butler, Addison/Steele e Chambers. Não daremos a cada um deles o pequeno destaque que conferimos a Locke porque o que nos interessa é mostrar não as críticas humianas a conclusões que ele considera errôneas em outras filosofias, mas o modo como a falsa filosofia se ergue a partir de certos princípios da natureza humana. Para isso, consideramos mais proveitoso mostrar de que modo a teoria de Hume sobre a identidade pessoal pode se prestar a uma crítica da filosofia do sujeito cartesiana. Na maior parte do tempo, afinal, pensadores como Shaftesbury, Butler e Addison são "poupados” por nosso autor, o que leva a crer que eles estão longe de serem os pensadores que ele consideraria grandes exemplos de má filosofia.

60 “[...] nothing can be more evident to us, than our own existence. I think, I feel pleasure and pain; can any of these be more evident to me, than my own existence? If I doubt of all other things, that very doubt makes me perceive my own existence $[\ldots]$...

${ }^{61}$ Cf. HUME 31, p. 414.
} 
filosóficas que não dizem respeito a nada que possa ser tratado pelos elementos que o mundo percebido nos oferece. Mais uma vez, portanto, o falso filósofo cria uma ficção sobre um outro mundo, totalmente descolado daquele percebido pelos homens comuns e, ainda que pretenda que sua teoria explique um suposto mundo real, sua explicação não resiste a um exame mais racional. Vemos, então, que as teorias que defendem a possibilidade de se provar a existência de um suposto eu (e, é claro, a possibilidade de se discursar sobre ele com base em princípios inteiramente racionais) incorrem nos mesmo problemas que afligiam a doutrina da dupla existência, as teorias sobre substâncias e acidentes e aquelas sobre qualidades primárias e secundárias, além de resultarem dos mesmos tipos de princípios ${ }^{62}$.

Como já havia acontecido no caso da discussão sobre os objetos externos, devemos explicitar, aqui, que o que foi dito sobre a identidade pessoal não implica necessariamente que Hume não aceite a própria existência do eu. Este apenas não pode ser objeto de uma teoria filosófica que pretenda tratá-lo como mais do que um feixe de percepções. Se formos considerar o eu como uma "base” para esse feixe, do mesmo modo como supostos objetos externos (ou uma substância, ou qualidades primárias) seriam o suporte para as percepções de cadeiras, árvores ou qualquer outra coisa desse tipo, devemos como que pressupor a existência dessa instância. Ela não pode ser de maneira nenhuma objeto de um discurso filosófico. No Capítulo III, discutiremos em que bases é possível essa "pressuposição”, tanto no caso dos objetos externos quanto no do próprio eu. Por ora, basta sabermos que Hume considera qualquer filosofia que se

\footnotetext{
${ }^{62}$ Poderíamos dizer, além disso, que Hume também enfraquece não apenas algumas filosofias do sujeito, mas boa parte das filosofias modernas, na seção "Do Ceticismo com relação à Razão". Nela, é desenvolvida a tese segundo a qual, ainda que as regras das ciências demonstrativas sejam certas e infalíveis, a aplicação delas incorre frequentemente em erro. Desse modo, Hume pretende conduzir as conclusões da matemática e da geometria ao patamar da probabilidade. Talvez uma de suas intenções tenha sido justamente atingir os modelos geometrizantes do conhecimento empregados por autores como Descartes, Espinosa e, até certo ponto, Hobbes. Entretanto, mesmo que seja esse o caso, não faremos aqui uma análise mais detalhada dessa seção, já que consideramos que sua contribuição para nosso propósito (o de verificar de que modo certos princípios da natureza humana originam a falsa filosofia) seria consideravelmente menor do que a daquelas que analisamos. O que procuramos descobrir aqui não é se Hume considera a razão matemática falível ou infalível, mas os motivos pelos quais os filósofos teriam sido levados a emprestar a sistemas falsos (inclusive aqueles que pressupõem a infalibilidade da razão) passam a gozar de enorme aceitação.
} 
proponha a falar sobre esses temas não apenas como errônea, mas como fictícia desde o princípio.

A seção “Da Identidade Pessoal”, portanto, reforça a lição das outras que havíamos acompanhado até aqui. O falso filósofo é apresentado como aquele que percebe certos erros cometidos pelo senso comum, mas limita-se a escondê-los. A recusa das opiniões do vulgo é, para ele, o ponto a partir do qual se inicia um discurso sobre um mundo que simplesmente não existe e, além disso, não pode ser compreendido por quem quer que seja, até porque as doutrinas dos falsos filósofos são, em última instância, completamente irracionais. As soluções atingidas por elas podem oferecer algum consolo àqueles que são incapazes de aceitar que não temos acesso a nada além de nossas percepções, mas, no fim das contas, não são nada além de uma tentativa de consolo.

Esses fatores são inseparáveis, para Hume, daquilo que ele considera a filosofia em suas formas falsas. Entretanto, não são de modo algum os únicos que a caracterizam. Para oferecer um quadro mais completo do que nosso autor considera a falsa filosofia e para atingir alguma compreensão de todo o impacto que ela pode ter, é preciso que dediquemos alguma atenção ao modo como a atividade filosófica em suas formas falsas aparece, ainda que dispersa, em obras nas quais nosso autor discorre sobre outros temas. É o que faremos a seguir. 


\section{CAPÍTULO II}

\section{QUE MALEFÍCIOS?}

No capítulo anterior, vimos de que modo a Parte 4 do Livro 1 do Tratado da Natureza Humana permite entrever algumas características daquilo que Hume considerava ser a falsa filosofia. Ficou evidente que, em muitos casos, ela se origina a partir de certas contradições inerentes à natureza humana e que, no fim das contas, nosso filósofo, ao menos no que diz respeito ao Tratado, tem por inimigo não essa mesma natureza, mas filosofias que não conseguem mais do que camuflar essas contradições. Essas formas da atividade filosófica, além de, segundo Hume, não resistirem a um exame racional mais detalhado, são apresentadas como demasiadamente distantes do senso comum, o que, como veremos, terminará por se tornar um problema enorme.

Entretanto, como já dissemos, não é apenas nos textos relativos à teoria do conhecimento que Hume discorre sobre a natureza da própria filosofia. Boa parte dos textos do filósofo escocês oferece algum tipo de observação sobre o que seria, para ele, a verdadeira filosofia, além de permitir que acrescentemos algo ao que poderia ser considerada, para ele, a atividade filosófica em suas formas falsas. Seria impossível, portanto, obter uma compreensão razoável da maneira como Hume vê a própria filosofia sem recorrer de algum modo a um número considerável de seus trabalhos. É a alguns deles que nos dedicaremos ao longo deste capítulo.

Antes de iniciar nossa análise propriamente dita, entretanto, convém que façamos uma pequena observação. Não nos deteremos, aqui, em separar esses textos segundo os temas a que se referem. O que não quer dizer, evidentemente, que não respeitaremos o contexto e o propósito de cada um deles, mas sim que trataremos apenas do que nos permitem dizer sobre a concepção humiana da própria atividade filosófica. Isso porque lidaremos, a seguir, com um conjunto de obras que trata de uma gama extremamente vasta de temas e, em um trabalho como este, seria impossível, além de extrair delas uma concepção de filosofia, realizar uma leitura detalhada dos outros 
temas nelas propostos, que incluem, por exemplo, moral, política, história e religião. Se levarmos em conta que esses temas parecem ocupar a maior parte das obras de Hume ${ }^{63}$, fica bastante evidente que deveremos lidar com um corpo textual imenso e bastante diversificado, o que basta para tornar a descoberta, quando da leitura deles, de uma concepção da atividade filosófica em suas formas verdadeira e falsa uma tarefa complicada o suficiente.

Vejamos, então, o que os textos de Hume referentes a temas diferentes da epistemologia permitem dizer sobre a sua concepção da falsa filosofia. Parece, em primeiro lugar, que, como já acontecia no Tratado, esses textos mostram que a filosofia sofre perdas inegáveis quando se distancia do ponto de partida que compartilha com o senso comum. Isso fica evidente, por exemplo, na seguinte passagem do ensaio "Of Essay Writing”:

Por outro lado, a erudição também perdeu muito ao ser trancada em colégios e em celas, e separada do mundo e da boa companhia. Por conta disso, todas as coisas a que chamamos Belles Lettres se tornaram completamente bárbaras, sendo cultivadas por homens sem qualquer gosto pela vida ou quaisquer maneiras, e sem aquela liberdade e facilidade de pensamento e de expressão que só podem ser adquiridas por meio da conversação. Até mesmo a filosofia se reduziu a destroços por esse método recluso e lamentoso de estudo, e se tornou tão quimérica em suas conclusões quanto ininteligível em seu estilo e em sua maneira de apresentação. E de fato, o que se poderia esperar de homens que nunca consultaram a experiência em nenhum de seus raciocínios, ou que nunca buscaram essa experiência que pode ser encontrada unicamente na vida comum e na conversação ${ }^{64}$ (HUME 37, pp. 534-5)

\footnotetext{
${ }^{63}$ Parece bastante acertada a observação feita por Adam Potkay em seu The Passion for Happiness, segundo a qual, ainda que Hume tenha sido por muito tempo comentado por autores que valorizaram principalmente seus textos epistemológicos, sua obra versa, na maior parte do tempo, sobre temas que hoje diriam respeito àquilo que poderíamos chamar de cultura.

64 " On the other Hand, Learning has been as great a Loser by being shut up in Colleges and Cells, and secluded from the World and good Company. By that Means, every Thing of what we call Belles Lettres became totally barbarous, being cultivated by Men without any Taste of Life or Manners, and without that Liberty and Facility of Thought and Expression, which can only be acquir'd by Conversation. Even Philosophy went to Wrack by this moaping recluse Method of Study, and became as chimerical in her Conclusions as she was unintelligible in her Stile and Manner of Delivery. And indeed, what ou'd be
} 
É bastante perceptível que Hume emprega, aí, um tom um pouco mais severo do que aquele que encontramos ao longo da Parte 4 do Livro 1 do Tratado. Duas explicações para isso se nos oferecem imediatamente. A primeira é que o texto de que retiramos a passagem acima é um ensaio escrito com o objetivo de atingir um público maior do que os acadêmicos que nosso autor esperava impressionar quando produziu seu trabalho de juventude e, como veremos posteriormente, esse é um aspecto bastante importante dos textos mais maduros de Hume, que, ao longo de sua carreira, promoveu um estreitamento cada vez maior da relação ente o filósofo e o homem comum. Assim, é natural que ele tenha se expressado de maneira mais, por assim dizer, inflamada, já que provavelmente não acreditaria que o público visado por ele receberia favoravelmente textos repletos de argumentos abstrusos e, além disso, escritos à maneira fria das escolas. De certo modo, parece óbvio que um texto que critica os filósofos presos à academia e os religiosos não deve ser escrito no mesmo estilo que podemos observar nesses tipos de autores. Temos, além disso, evidências textuais para desconfiar que Hume, ao se dirigir a um público mais amplo, tende a não empregar argumentos que considera excessivamente longos ou cansativos. Para ele, existe uma relação inegável entre o conteúdo de um texto e a maneira como ele deve ser escrito. Isso fica evidente, por exemplo, na carta de Pânfilo para Hermipo, com que Hume abre os Diálogos sobre a religião natural. Nela, o filósofo procura exatamente justificar o fato de ter decidido tratar da religião natural em um diálogo. Começa afirmando que essa forma, tão em voga entre os antigos, não é mais tão comum em seu próprio tempo, o que se deve ao fato de "o argumento preciso e regular, de fato, tal como é atualmente esperado em investigadores filosóficos, naturalmente coloca o homem em um estado metódico e didático, em que ele pode, imediatamente e sem preparação, explicar o ponto que tem em vista ${ }^{65}$ " (HUME 39. p.143). Pouco depois, nosso autor afirma que há assuntos aos quais a forma dialógica é particularmente bem adaptada, e o da religião é um deles. Temos aí uma boa evidência de que Hume consideraria certos tipos de texto

expected from Men who never consulted Experience, where alone it is to be found, in common Life and Conversation?”

65 “Accurate and regular Argument, indeed, such as is now expected of philosophical Enquirers, naturally throws a man into the methodical and didactic manner; where He can immediately, without Preparations, explain the Point, at which he aims [...]”. 
(e isso inclui, é claro, o tom apropriado a ser adotado em cada tipo de texto) como mais adequados ao certos temas ${ }^{66}$.

Podemos concluir, então, sem grandes dificuldades, que Hume certamente tinha em mente a melhor maneira de se comunicar com o público a que se dirigia, o que não poderia deixar de influenciar o tom adotado por ele na passagem já mencionada de "Of Essay Writing”. Entretanto, existe também uma outra explicação para o fato de nosso autor se mostrar mais severo nessa passagem, e é ela que nos interessa. E essa outra explicação não deve de modo algum ser considerada menos verdadeiramente “filosófica”. Defenderemos, nos capítulos seguintes, que a maneira como se dá a relação entre filosofia e senso comum é um aspecto importante do pensamento de humiano e, mais do que isso, um problema de que, para nosso autor, a própria filosofia deve, sem a menor dúvida, se ocupar. De qualquer modo, o motivo pelo qual a segunda explicação nos interessa mais é que ela nos permitirá entrever algo mais sobre a maneira como Hume vê a atividade filosófica em suas formas falsas. Vejamos, então, o que se pode extrair daquela passagem sobre a falsa filosofia.

Como já dissemos, essa passagem deixa claro algo que já havia ficado estabelecido no capítulo anterior, a saber, que o distanciamento com relação ao senso comum é precisamente uma das características que fazem da má filosofia o que ela é. Até aí, nada de novo. Porém, a passagem de “Of Essay Writing” que mencionamos traz à tona um outro aspecto interessante: nela, o falso filósofo é apresentado como um ser que, totalmente desligado da vida comum e da conversação, estuda de modo recluso e lamentoso e, por conta disso, chega a conclusões quiméricas que ele expressa em um estilo ininteligível. A participação na vida social não é, para Hume, algo que poderia conferir ao filósofo apenas vantagens estilísticas. Em outras palavras, ao se enclausurar e abrir mão da vida comum, o falso filósofo não abre mão simplesmente de ferramentas melhores com que atingir seus leitores, ou de uma boa estratégia de marketing. $\mathrm{O}$ falso

\footnotetext{
${ }^{66}$ A discussão sobre a possibilidade de se utilizar passagens dos Diálogos sobre a religião natural para validar esta ou aquela leitura de Hume é recorrente entre os comentadores, e parece ser uma discussão sem fim, já que é possível reconhecer teses humianas em falas dos três personagens. Alguns intérpretes, como Galen Strawson, simplesmente identificam as posições de Filo às do autor (Cf. STRAWSON 91, p. 37), mas isso nos parece ser de um simplismo inaceitável, por motivos que discutiremos posteriormente. De qualquer maneira, parece-nos que buscar reconhecer, ao longo dos Diálogos, teses com as quais Hume não parece ter problemas ao longo de toda a sua obra é algo bastante seguro. Assim, afirmamos sem muita hesitação que essa passagem da carta de Pânfilo a Hermipo reflete, sem grandes dúvidas, a opinião de Hume.
} 
filósofo não é alguém que, coincidentemente, se enclausura ao mesmo tempo em que se engana; ele se engana porque se enclausura.

Evidentemente, o que Hume pretende nessa passagem não é apenas recomendar a seus colegas filósofos que tenham alguma vida social (ainda que, como em outros momentos de sua obra, esse conselho esteja aí presente). O que ocorre é que o falso filósofo, ao tornar-se completamente recluso, abandona o recurso a uma forma de experiência que só poderia ser conseguida por meio da participação na vida comum. Assim, é bastante natural, como veremos na próxima seção, que ele passe a criar ficções que, apesar de não terem exatamente o mesmo mecanismo daquelas que vimos no capítulo anterior, são no mínimo tão condenáveis quanto elas. Isso parece ainda mais evidente quando lembramos que, na Conclusão do Livro 1 do Tratado, Hume afirma que não pretende tornar filósofos os homens comuns, ainda que atribua a eles considerável bom senso, mas que gostaria, como já observamos, de “comunicar a nossos fundadores de sistemas uma porção dessa mistura terrena grosseira, que é um ingrediente que comumente lhes faz muita falta, e que serviria para temperar aquelas partículas incandescentes de que eles são compostos ${ }^{67 ”}$ (HUME 31, p. 177). Como esperamos que fique cada vez mais claro, é como se o falso filósofo incorresse em erro porque se retira completamente do mundo da experiência comum e passa a criar um sistema totalmente independente dele, tentando, depois, fazer com que o mundo percebido se encaixe em um sistema que simplesmente não corresponde a nada ${ }^{68}$.

\section{A falsa filosofia e as morais do amor próprio}

Tudo isso fica evidente, por exemplo, no tratamento conferido por Hume às morais do amor próprio no Apêndice 2 da Investigação sobre os princípios da moral.

\footnotetext{
6767 “[...] communicate to our founders of systems, a share of this gross earthy mixture, as an ingredient, which they commonly stand much in need of, and which wou'd serve to temper those fiery particles, of which they are compos'd".

${ }^{68}$ Nesse ponto, como já dissemos, crédito considerável é devido a Donald Livingston, que captou muito bem esse aspecto do caráter do falso filósofo no capítulo 2 de seu Philosophical Melancholy and Delirium. Mas é pena que, além de incorrer nos pecadilhos que ressaltamos no capítulo anterior, ele tenha ido além e classificado o falso filósofo em três categorias (heroico, revolucionário e culpado) que não podem ser encontradas nos textos do próprio Hume. Por vezes, o modo de se expressar empregado por Livingston faz parecer que o que ele pretende é, no fim das contas, buscar nos textos de Hume a corroboração de certas teses que são, em última instância, livingstonianas.
} 
Nele, o autor apresenta, de maneira bastante resumida, as duas principais teorias que procuram resumir ao amor próprio todos os julgamentos morais. A primeira delas, que podemos supor sem grandes problemas ser a de Mandeville, é aquela segundo a qual todos os sentimentos benevolentes apresentados pelos seres humanos são considerados apenas como disfarces que empregamos para extrair de nossos convivas tantas vantagens quanto for possível. Hume atribui essa teoria ao fato de que pensadores superficiais, “observando muitos fingimentos entre os homens e sentindo, talvez, não ter grandes pudores em sua própria disposição, poderiam tirar a conclusão geral apressada de que todos são igualmente corruptos, e que os homens, diferentemente dos outros animais e, na verdade, de todas as outras espécies de existência, não admitem graus de bom ou mau, mas são, em todos os casos, as mesmas criaturas sob diferentes disfarces e aparências $^{69 ”}$ (HUME 33, p. 1664).

A segunda das teorias que buscam reduzir toda a moralidade ao amor próprio é, certamente, a hobbesiana, que Hume também atribui a Locke. De acordo com ela, “por um refinamento ou uma reflexão, por um entusiasmo da paixão, parecemos nos envolver com os interesses dos outros, e imaginamos estar desnudados de todas as considerações egoístas. Mas, no fundo, o patriota mais generoso e o avarento mais mesquinho, o herói mais bravo e o covarde mais abjeto têm, em cada uma de suas ações, uma igual preocupação com sua própria felicidade e seu próprio bem-estar ${ }^{70 \text {, }}$ (HUME 33, pp. 164-5). Em outras palavras, os hobbesianos admitem que temos sentimentos que consideramos altruístas, mas concentram seus esforços em mostrar de que maneira mesmo eles podem ser todos reduzidos ao amor próprio.

Não nos interessa realizar, aqui, uma reconstrução detalhada dos argumentos empregados por Hume para refutar as morais do amor próprio. Voltamo-nos para o Apêndice 2 da segunda Investigação porque ele permite que teçamos mais algumas observações no que diz respeito à concepção humiana da falsa filosofia. Vejamos, antes

\footnotetext{
69 “[...] observing many false pretences among mankind, and felling, perhaps, no very strong restraint in their own disposition, might draw a general and a hasty conclusion, that all is equally corrupted, and that men, different from all other animals, and indeed from all other species of existence, admit of no degrees of good or bad, but are, in every instance, the same creatures under different disguises and appearances".

70 “[...] by a refinement of reflection, by an enthusiasm of passion, we seem to take part in the interests of others, and imagine ourselves divested of all selfish considerations: But, at bottom, the most generous patriot and most niggardly miser, the bravest hero and most abject coward, have, in every action, na equal regard to their own happiness and welfare".
} 
de qualquer outra coisa, de que modo essa seção confirma o que já havíamos dito sobre o distanciamento da falsa filosofia e do senso comum. Quanto a isso, o que Hume afirma é que, mesmo que seja possível reduzir ao amor próprio todas as paixões, digamos, altruístas, estimamos aqueles cujo amor próprio os torna, por quaisquer que sejam os meios, preocupados com o bem dos outros e úteis à sociedade. O inverso, evidentemente, ocorre, com aqueles que não buscam nada além de satisfazer seus próprios desejos. Ora, para as morais do amor próprio de caráter hobbesiano, bastaria uma variação de pensamento muito pequena para que esses dois caracteres pudessem surgir de um mesmo princípio. A resposta de Hume a esse tipo de teoria é que cada caráter, “mesmo com essas diferenças insignificantes, parece para mim, na prática, bem durável e intransmutável. E não descubro nesse, mais do que em outros assuntos, que os sentimentos naturais que surgem da aparência geral das coisas são facilmente destruídos

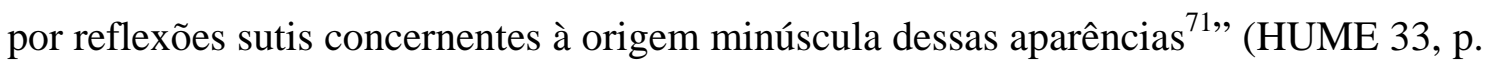
165). Em outras palavras, nosso filósofo, para dizer o mínimo, acredita que as conclusões alcançadas por aqueles que defendem as morais do amor próprio simplesmente não teriam a menor condição de sobreviver no mundo compartilhado pelos homens comuns. Isso, é claro, não basta para que elas sejam descartadas. Como veremos no capítulo seguinte, existem conclusões que, ainda que não sobrevivam no mundo da convivência, são irrefutáveis pela razão. Esse é um fato que terminará por gerar uma tensão que Hume se verá obrigado a resolver. Definitivamente, não é isso que acontece no caso das teorias morais baseadas no amor próprio, que serão devidamente refutadas por nosso autor na sequência do texto. O que nos interessa é, por ora, observar essa aparente primazia da vida comum sobre conclusões que parecem entrar em conflito direto com ela. De certa maneira, é como se os hobbesianos, por ignorarem exatamente o conselho que lhes seria oferecido pela experiência da conversação, aderissem a um princípio que não se verifica quando prestamos atenção ao modo como as coisas se dão no mundo. Parece sensato afirmar que Hume veria, aí, um erro na própria maneira de filosofar desses pensadores. Isso faz sentido se pensarmos, por exemplo, na maneira como Hobbes articulara seu Leviatã. Nessa obra, ele constroi primeiramente um modelo de homem e procura, a partir daí, extrair as conclusões que compõem suas teorias

\footnotetext{
71 “[...] notwithstanding these inconsiderable differences, appears to me, in practice, pretty durable and untransmutable. And I find not in this, more than in other subjects, that the natural sentiments, arising from the general appearances of things, are easily destroyed by subtile reflections concerning the minute origin of these appearances".
} 
referentes à moral e à política. Não parece que esse mesmo método de raciocínio poderia ser aplicado à teoria humiana. Ainda que, diferentemente do que vemos na Investigação sobre os princípios da moral, a teoria sobre os fundamentos da moralidade exposta no Tratado seja apresentada como partindo de princípios de para se chegar a conclusões mais amplas, não há como negar que os próprios princípios iniciais são derivados de um recurso à experiência. A colocação do sentimento como base de toda a moralidade, por exemplo, é apresentada a partir da observação de que somos acometidos por um sentimento desagradável quando contemplamos um ato como o homicídio voluntário, ou quando pensamos nele.

Essas observações, entretanto, não bastam para que Hume considere ganho o caso contra os defensores das morais do amor próprio. A “hipótese egoísta” tem, para nosso autor, grande impacto quando falamos da ciência especulativa da natureza humana, ainda que não tenha maior importância para a prática da moral. Assim, é preciso, diz Hume, fazer mais algumas reflexões sobre as teorias "egoístas” da moralidade. Isso pode soar estranho, já que poderia parecer, pelo que defendemos até aqui, que existe algo como uma discordância de princípio, ou, para dizer o mínimo, metodológica entre a filosofia humiana e suas adversárias que advogam o amor próprio. Entretanto, não devemos perder de vista que Hume não pode simplesmente pressupor que bastará refutar seus adversários simplesmente alegando que eles se enganam por adotar outra concepção de filosofia, sem discutir em mais detalhes as próprias afirmações realizadas por eles. De qualquer maneira, a primeira objeção, por assim dizer, mais filosófica que veremos na sequência do Apêndice 2 será justamente a de que a hipótese egoísta, por ser “contrária ao sentimento comum e a nossas noções mais despidas de preconceitos, requer o maior tensionamento filosófico para estabelecer um paradoxo tão extraordinário ${ }^{72, " ~(H U M E ~ 33, ~ p . ~ 166) . ~ C o m o ~ s e ~ s a b e, ~ a s ~ p e s s o a s ~ c o m u n s ~}$ simplesmente parecem sentir coisas como benevolência, generosidade, amor, amizade, compaixão. Mais do que isso, segundo Hume, as causas, os efeitos, os objetos e as operações desses sentimentos aparecem como totalmente distintos daqueles que operam nas afecções egoístas, e isso se faz notar tanto na linguagem comum quanto na observação. Desse modo, é natural que todos os esforços para tentar explicar todas as paixões a partir do amor próprio se tenham mostrado, em última instância, infrutíferos.

\footnotetext{
72 “[...] contrary to common feeling and our most unprejudiced notions, there is required the highest stretch of philosophy to establish so extraordinary a paradox".
} 
Nosso filósofo atribui essas tentativas, então, a um suposto amor pela simplicidade. Quer dizer, com isso, que tais autores considerariam que essa explicação seria, por assim dizer, menos abstrusa e, talvez, menos dependente de raciocínios intrincados ${ }^{73}$. Isso parece ser desmentido pelo próprio esforço que os defensores das morais do amor próprio precisam fazer para conseguir reduzir todos os nossos sentimentos ao amor próprio. Como veremos em breve, Hume considera que sua própria hipótese tem, no fim das contas, mais simplicidade que a egoísta. Além disso, nosso autor não considera possível, mesmo em um futuro distante, que seja desenvolvida uma explicação realmente satisfatória para o modo como os sentimentos benevolentes possam ter surgido dos egoístas.

Nesse ponto, parece haver, para Hume, uma diferença substancial entre as ciências morais e a física. No caso desta última, explicações contrárias ao senso comum seriam frequentemente corretas. Nas primeiras, definitivamente não parece ser o caso. No caso das últimas, porém, “a causa mais simples e mais óbvia que pode ser atribuída a qualquer fenômeno é, provavelmente, a verdadeira ${ }^{74,}$ (HUME 33, p. 167). Desse modo, sempre que um filósofo se vê obrigado a recorrer a raciocínios muito intrincados ou refinados para explicar a causa de uma paixão, temos motivos para desconfiar dele. Os motivos para isso ficam mais que evidentes na passagem a seguir:

As afecções não são suscetíveis de qualquer impressão que parta dos refinamentos da razão ou da imaginação, e sempre se descobre que um exercício vigoroso destas últimas, necessariamente, por conta da estreita capacidade da mente humana, destroi toda a atividade na primeira. Nosso motivo ou nossa intenção dominante está, de fato, frequentemente escondido de nós mesmos, quando se mistura e se confunde com outros motivos, que a mente, por vaidade ou por

\footnotetext{
${ }^{73}$ Devemos notar que Hume não explicita, em seu texto, o que quer dizer ao falar em simplicidade nesse contexto. Essa apenas nos pareceu a interpretação mais plausível. Poderíamos pensar que a simplicidade pretende designar, aqui, apenas a explicação a partir do menor número possível de princípios, de modo que a hipótese do amor próprio seria imbatível nesse aspecto por supor apenas um, no caso, esse mesmo amor próprio. Porém, nosso filósofo tratará de declarar, mais adiante, que sua própria hipótese, tem mais simplicidade, e sabemos que ela emprega um número maior de princípios. Desse modo, parece que a simplicidade não é dada apenas pelo número de "causas primeiras" afirmadas por uma hipótese, mas também pela quantidade e pela complexidade da, por assim dizer, construção teórica empregada para justificar certa explicação.

74 "The simplest and most obvious cause, which can there be assigned for any phaenomenon, is probably the true one".
} 
convencimento, está desejosa de supor mais prevalentes. Mas não há exemplo em que o ocultamento dessa natureza tenha surgido da abstrusidade e da complicação do motivo ${ }^{75}$. (HUME 33, p. 167)

Os exemplos que Hume apresenta em seguida completam o argumento: um homem cujo benfeitor morra talvez apenas tente se convencer de que se entristeceu por motivos altruístas, mas estes podem estar misturados ao interesse que ele tinha na prosperidade do próprio benfeitor. Por outro lado, parece impossível explicar, a partir unicamente do amor próprio, a tristeza de alguém que perde uma pessoa que era, na verdade, um dependente e que, talvez, chegasse mesmo a ser causa de inconvenientes.

A passagem que acabamos de mencionar, mais os exemplos que nosso autor nos oferece em seguida, permite que extraiamos algumas considerações sobre o modo como as morais do amor próprio são retratadas pela filosofia humiana. Se frequentemente não conseguimos descobrir nem mesmo nossas próprias intenções, não é porque elas próprias são bastante abstrusas. O homem que perde seu benfeitor talvez sinta tanto a perda da satisfação de seus interesses quanto uma tristeza por motivos, digamos, benevolentes. O caso é que ele provavelmente não distinguirá a parte de sua tristeza motivada pelo interesse não porque isso envolveria algum cálculo extremamente complicado, mas porque deseja que a intenção que supõe virtuosa seja prevalente. Esse exemplo é importante, então, porque expressa a rejeição, por parte de Hume, de quaisquer explicações abstrusas e completamente descoladas da experiência que procurem reduzir mesmo as paixões mais benevolentes ao amor próprio. Isso é complementado, é claro, pelo segundo exemplo, em que nosso autor afirma que seria impossível, recorrendo apenas à experiência comum, atribuir motivos apenas egoístas para o luto daquele que perde um dependente.

\footnotetext{
75 "The affections are no susceptible of any impression from the refinements of reason or imagination; and it is always found that a vigorous exertion of the latter faculties, necessarily, from the narrow capacity of the human mind, destroys all activity in the former. Our predominant motive or intention is, indeed, frequently concealed from ourselves, when it is mingled and confounded with other motives, which the mind, from vanity or self-conceit, is desirous of supposing more prevalent: But there is no instance, that a concealment of this nature has ever arisen from the abstruseness and intricacy of the motive". Talvez seja oportuno informarmos que, como o leitor talvez tenha percebido, traduzimos "self-conceit" como convencimento tendo em mente não uma possível ação em que alguém tenta convencer a si mesmo, mas o uso da palavra "convencido" como nos casos em que é usado para designar popularmente uma pessoa com uma imagem excessivamente elevada de si mesma. O ponto que Hume procura estabelecer, afinal, é que, de fato, há casos em que alguém quer se considerar mais virtuoso do que realmente é. De qualquer maneira, como vemos no corpo do texto, isso não invalida as críticas apresentadas por ele às morais do amor próprio.
} 
É importante observarmos que, nesse momento, Hume não tem em mente apenas as teorias morais de cunho hobbesiano entre seus alvos. O que ele pretende é mostrar, também, que na prática, além de ser impossível reduzir os sentimentos benevolentes ao amor próprio, é fato que, na vida cotidiana, os homens não fazem cálculos com base apenas em seus interesses para verificar em que situações é conveniente para eles agir de maneira benevolente. Nosso filósofo também pretende, então, atacar a primeira das teorias do amor próprio que mencionara no início do Apêndice II, ou seja, aquela que atribuímos principalmente a Mandeville, e segundo a qual o homem apenas fingiria benevolência quando, na verdade, tem sempre em vista apenas os seus próprios interesses. Isso fica ainda mais claro no exemplo seguinte, em que se afirma que os animais são suscetíveis à gentileza, tanto com membros de sua própria espécie como com os da nossa, e que isso não poderia, no caso deles, provir de cálculos refinados com relação às vantagens que isso acarretaria. E não há qualquer motivo, para Hume, por que deveríamos aceitar uma benevolência desinteressada nas “espécies inferiores”, mas recusar que ela possa ocorrer entre seres humanos. Em seguida, ele faz referência às afecções benevolentes engendradas pelo amor entre os sexos, além de mencionar as mães que, por amor seus filhos, chegam mesmo a adoecer por não medir esforços em seus cuidados. Atenta, ainda, para a benevolência que inegavelmente sentimos por nossos amigos.

Além desses exemplos, nosso autor diz que poderia citar mil outros que são, para ele, marcas de uma benevolência geral na natureza humana. Com isso, ele quer dizer que temos uma "simpatia” geral que nos faz sentir compaixão pelas dores alheias, bem como felicidade pelos prazeres dos outros ${ }^{76}$. Além disso, seria impossível reduzir esses sentimentos a interesses imaginários.

Hume retorna, então, à questão da simplicidade, para mostrar que sua própria teoria tem mais dela que as moralidades do amor próprio, além de ser mais conforme à analogia da natureza. Segundo a moral humiana, há paixões mentais que têm seus próprios objetos, do mesmo modo que a fome, por exemplo, nos leva a buscar comida. E a fome, para ficar em um exemplo, ao ser satisfeita, provoca um prazer, que pode se tornar o objeto de uma outra espécie de desejo. Algo similar ocorre, por exemplo, com paixões como os desejos por fama, poder ou vingança. Alguém que não seja vaidoso

\footnotetext{
${ }^{76}$ Cf. HUME 33, p. 166 n. 60.
} 
não obterá grande prazer com a fama, do mesmo modo que alguém que não tenha ambição não terá por que buscar o poder e alguém que não esteja enraivecido com um inimigo permanecerá indiferente ao vê-lo punido. Nesses casos, diz Hume, estamos falando de paixões que remetem diretamente a seus objetos e os constituem como nosso bem ou nossa felicidade. Apenas posteriormente é que surgem outras paixões, secundárias, que também passamos a perseguir como parte de nossa felicidade. O ponto é que, se não houvesse paixão alguma anteriormente ao amor próprio, ele não teria meios para se exercer, já que, nesse caso, nossas dores seriam poucas e fracas, bem como nossos prazeres. E já que é assim, Hume pergunta, “qual é a dificuldade em conceber que esse pode ser, do mesmo modo, o caso da benevolência e da amizade, e que, a partir da constituição original de nosso temperamento, podemos sentir um desejo pela felicidade ou o bem de outrem, que, por meio dessa afecção, se torna nosso próprio bem, e é posteriormente perseguido, pelos motivos combinados da benevolência e do amor próprio? ${ }^{77, "}$ (HUME 33, pp. 168-9).

Vemos, então que alguns pontos que já havíamos identificado como característicos da falsa filosofia estão presentes, segundo Hume, nas morais do amor próprio. Primeiramente, podemos destacar que, como já havíamos dito, elas não fundamentam suas conclusões na experiência. Parecem, isso sim, buscar algo como uma causa única a partir da qual poderíamos deduzir todas as paixões que não o amor próprio em que tentam apoiá-las. No caso específico da teoria que atribuímos a Mandeville, isso pode causar algum estranhamento, já que, em uma nota na Introdução do Tratado, Hume o coloca, juntamente com Shaftesbury, Hutcheson e Butler, entre aqueles que "começaram a por a ciência do homem em um novo patamar" (HUME 31, p. 5). Ora, ainda que nosso filósofo não aceite a teoria moral proposta por Butler e não esteja plenamente de acordo com Shaftesbury ou Hutcheson, autores com quem parece estar mais alinhado, não faz um grande esforço para estender a ele reprimendas concernentes especificamente a suas próprias maneiras de filosofar. Isso não quer dizer, é claro, que Hume esteja completamente de acordo com a maneira pela qual eles haveriam conduzido suas investigações. Como veremos ainda neste capítulo, o teísmo de que Butler era adepto é visto por Hume como algo extremamente pernicioso e, se

\footnotetext{
77 " [...] where is the difficulty in conceiving, that this may likewise be the case with benevolence and friendship, and that, from the original frame of our temper, we may feel a desire of another's happiness or good, which, by means of that affection, becomes our own good, and is afterwards pursued, from the combined motives of benevolence and self-enjoyment?”.
} 
dizemos que nosso autor não se demorou ao censurar a maneira pela qual o bispo filosofava, é simplesmente porque parece que os aspectos particulares de sua obra que mais chamaram a atenção de nosso autor eram de outra natureza, enquanto o teísmo em geral era um inimigo mais premente. Inclinações deístas, como as de Shaftesbury, também são duramente criticadas por Hume em seus Diálogos sobre a religião natural, mas o alvo, nesse texto, não parece ser um deísta especificamente, mas o argumento do desígnio e a "religião dos filósofos” em qualquer formato. Hutcheson, por sua vez, certamente não conseguiria fazer com que sua teleologia moral fosse aprovada por Hume. Isso fica claro não apenas nas obras em que nosso autor desenvolve sua própria teoria moral, mas fica bastante explícito em uma carta que ele endereçou ao próprio Hutcheson:

Não posso concordar com o sentido com que você emprega a palavra "natural”. Ela está fundamentada em causas finais, e essa é uma consideração que me parece bastante incerta e não filosófica. Pois diga-me, qual é a finalidade do homem? Ele é criado para a felicidade ou para a virtude? Para esta vida ou para a próxima? Para si próprio ou para seu criador? Sua definição de natural depende da solução dessas questões, que são intermináveis, e muito distantes do meu propósito ${ }^{78}$. (HUME 37, p. 34)

Essa passagem nos faz pensar que Hume certamente veria em Hutcheson, mesmo que o considerasse uma grande inspiração, um pensador que falha ao supor, para além do que lhe permite a experiência, causas finais para oferecer uma definição de natureza. O que Hume teria a censurar a Hutcheson, mesmo sendo ele uma grande inspiração, seria o fato de ele endossar o argumento do desígnio. Ainda que nosso filósofo tenha sido influenciado por autores deístas, isso certamente se deveu mais à sua teoria moral baseada no sentimento do que a suas afirmações sobre a divindade. Está claro que, quando pensamos em termos humianos, não há como considerar que Hutcheson teria qualquer bom argumento para inferir a divindade a partir da natureza

\footnotetext{
78 "I cannot agree to your Sense of Natural. 'Tis founded on final Causes; which is a Consideration, that appears to me pretty uncertain \& unphilosophical. For pray, what is the End of Man? Is he created for Happiness or for Virtue? For this Life or for the next? For himself or for his Maker? Your Definition of Natural depends upon solving these Questions, which are endless, \& quite wide of my Purpose”.
} 
observada. Entretanto, é possível pensar a moral hutchesoniana em termos mais naturalistas, não apenas de modo teleológico, de modo que, mesmo que ele tenha aceitado causas finais baseado simplesmente em crenças religiosas, não é tão complicado compreender os motivos que fizeram dele uma inspiração para a teoria moral humiana. No fim das contas, o caso é que, mesmo pressupondo uma divindade e aceitando, consequentemente, uma doutrina finalista, Hutcheson parece ser uma referência importante por concentrar seus esforços em desvendar princípios da natureza humana, de modo que atribuir a responsabilidade pela existência desses princípios a uma causa final não o torna automaticamente um investigador menos capaz quando se trata de, por assim dizer, mapear esses princípios.

Algo parecido poderia ser dito de Shaftesbury. É verdade que Hume procurou, em boa parte de seus controversos Diálogos sobre a religião natural, demolir os argumentos que sustentariam a "religião dos filósofos", mas o conde inglês havia sido responsável, principalmente em seu Sensus Comunis por uma teoria que, a partir de princípios da natureza humana, explicar a origem social da moralidade e, ainda assim, preservar a normatividade das regras morais. Ainda que a Enquiry concerning virtue, or merit, a primeira obra em que teria sido usada a expressão moral sense, tenha um tom inegavelmente teleológico, isso não invalida o fato de ele ter buscado uma solução em algo que poderia ser considerado por Hume um exemplo de estudo da natureza humana.

Butler, como já indicamos, é um caso mais complicado. Hume o arrola, certamente, entre aqueles que buscaram elevar a ciência do homem a um novo patamar. Entretanto, como já insinuamos, Hume censura nele não apenas as inclinações religiosas, mas a noção segundo a qual a razão poderia derivar as regras da moralidade de uma investigação das relações entre as coisas do mundo. Desse modo, ainda que tenha cortejado as atenções de Butler em sua juventude, além de atribuir a ele um papel importante no sentido de inspirar sua própria construção de sua própria filosofia, Hume parece ter mais reservas com relação a ele do que com relação a Shaftesbury e a Hutcheson. Isso não quer dizer, entretanto, que Hume não perceba o trabalho realizado por Butler no sentido de anatomizar a natureza humana, que pode ser percebido, por exemplo, em sua teoria das paixões e em sua teoria sobre os hábitos (que, devemos notar, é substancialmente diferente da teoria humiana, além de não cumprir, para Butler, o papel essencial que o filósofo escocês atribuiria à noção de hábito em seus escritos epistemológicos). Ainda assim, é importante observarmos que, ao criticar as morais 
racionalistas na Seção 1 da Parte 1 do Livro 3 do Tratado, Hume não parece preocupado em atingir Butler mais do que os argumentos de outros partidários dessa “corrente”. Além disso, podemos notar que mesmo a relação do filósofo escocês com aqueles que, ao defender teorias morais baseadas no sentimento, teriam sido suas maiores inspirações não é exatamente desprovida de tensão. Isso porque, tanto em Shaftesbury quanto em Hutcheson, poderíamos dizer que o sentimento revela, de certa maneira, algo realmente existente na natureza ${ }^{79}$, enquanto Hume buscou construir uma teoria que, a partir de certos princípios da natureza humana, fundamentasse a moralidade com base em um sentimento que garantiria sua normatividade ao aprovar aquilo que fosse útil para a preservação da vida social. Ainda assim, seria impossível tentar negar a inspiração que a moral humiana certamente encontrou em teorias anteriores que também buscavam basear a moralidade no sentimento, especialmente quando observamos que nosso filósofo não considerava as distinções morais como esvaziadas de realidade apenas porque o critério de aprovação pelo sentimento era não uma teleologia exterior, mas simplesmente a utilidade social.

Parece-nos, então, que as discordâncias de Hume em relação a Hutcheson e a Shaftesbury não são tão exploradas não porque esses autores tenham feito, o tempo todo, aquilo que Hume chamaria de boa filosofia, mas pelo fato de o filósofo escocês reconhecer que é, em grande medida, tributário deles. Isso não quer dizer, é claro, que textos como os Diálogos sobre a religião natural e a História natural da religião não tragam críticas que poderiam ser aplicadas a qualquer um que aceite alguma forma de teleologia, quer nosso filósofo se considerasse tributário dele, quer não ${ }^{80}$. O que acontece é que os textos morais de Hume parecem mostrar um teor menos polêmico com relação a eles, a não ser, é claro, na própria Seção 1 da Parte 1 do Livro 3 do Tratado, em que Hume desconstroi os principais argumentos empregados pelos racionalistas morais. E nesse caso, parece que Butler, ainda que Hume tivesse para com ele uma certa dívida, sofre as críticas mais pesadas, já que ele poderia ser considerado

\footnotetext{
${ }^{79}$ Aqui, empregamos o termo "natureza" em um sentido mais amplo. Em outras palavras, ele se refere, nessa passagem, a algo que não se limita aos homens, mas, digamos, a todo um universo, até mesmo entendido como inegavelmente existente de maneira exterior à mente. Evidentemente, nessa frase, "natureza" é um termo que usamos em oposição à expressão natureza humana. Caso seja necessário, trataremos de informar o leitor quando isso acontecer novamente.

${ }^{80}$ Evidentemente, não pretendemos afirmar, aqui, que todos esses textos trazem críticas a todos esses autores, como já deve estar evidente a esta altura.
} 
partidário de uma corrente que erra não apenas por ir além do que a experiência permite, mas, também, por defender um fundamento para a moralidade que depende de um conceito de razão que, definitivamente, não é aquele que nosso autor consideraria que é aplicável ao estudo da realidade que percebemos.

Entretanto, Hume não parece ter grandes pudores ao atacar, no Apêndice 2 da segunda Investigação, a teoria moral de Mandeville, de maneira muito mais aguerrida do que aquela que havia empregado, por exemplo, na Seção 1 da Parte 1 do Livro 3 do Tratado. Isso não se deve apenas ao fato de o médico holandês e os hobbesianos serem provavelmente o alvo principal de toda a segunda Investigação, provavelmente concebida, entre outras coisas, como um libelo contra aqueles que Hume denominava céticos morais. Em primeiro lugar, porém, devemos deixar claro que esse é um aspecto que não podemos ignorar, e que não é exatamente difícil de compreender. Como Hume, Mandeville teria extraído suas conclusões acerca dos fundamentos da moralidade partindo de um registro exclusivamente fatual. Recusando os fundamentos teleológicos da filosofia de Shaftesbury, ele teria chegado a uma teoria segundo a qual seria do interesse dos piores entre os homens pregar o espírito público, uma vez que este passasse a ser considerado algo valioso. Com isso, segundo Mandeville, eles poderiam satisfazer seus apetites de maneira menos incômoda ao mesmo tempo em que colhessem o fruto do trabalho e do altruísmo dos outros ${ }^{81}$. Esses outros seriam, no caso, aqueles que realmente conseguiram negar sua natureza inicial e manterem sob controle seus apetites em nome do bem da sociedade. Não seria errado afirmar, então, que os homens que tradicionalmente consideraríamos virtuosos são tratados, ao longo da Fábula das Abelhas de Mandeville, simplesmente como não sendo muito espertos. Hutcheson, ao escrever seus textos morais, tê-los ia pensado, em grande medida, como uma resposta a Mandeville e, também, aos hobbesianos ${ }^{82}$. A solução hutchesoniana, porém, era,

\footnotetext{
${ }^{81}$ Cf. MANDEVILLE 57, p. 48.

${ }^{82}$ É importante notarmos que, para boa parte dos moralistas britânicos do século XVIII, "hobbesianos" eram todos aqueles que advogavam em favor das morais do amor próprio. Ainda assim, não podemos negar o impacto da obra de Mandeville nas discussões que aconteceram à época sobre o fundamento da moralidade, de modo que acreditamos ser justo afirmar que a Fábula das Abelhas foi uma motivação importante para as respostas de Hutcheson. Ainda assim, ele parece ter tido o próprio Hobbes como alvo central em alguns de seus escritos. Uma confirmação importante nesse sentido pode ser encontrado em suas Reflections on Laughter, em que ele ataca a teoria hobbesiana segundo a qual tenderíamos a rir daqueles que se encontram em situação pior que a nossa. A teoria do riso desenvolvida por Hobbes, como se sabe, está diretamente vinculada à sua teoria moral baseada no amor próprio.
} 
também, teleológica, de modo que a resposta oferecida por Hume na segunda Investigação, ao excluir completamente a teleologia, poderia ser considerada uma tentativa de enfrentar o adversário no terreno puramente fatual que o havia conduzido à moral do amor próprio.

Por outro lado, existe um outro aspecto das teorias de Hobbes e Mandeville que pode ter contribuído para que um Hume já maduro escolhesse voltar contra eles suas baterias na segunda Investigação. Quando observamos a Seção 1 da Parte 1 do Livro 3 do Tratado, vemos críticas pontuais a cada aspecto que das teorias morais racionalistas que criavam problemas teóricos. Em outras palavras, o Hume do Tratado limitou-se a apresentar objeções contra certas conclusões racionalistas. É claro que isso não quer dizer que ele as considerasse como perfeitamente conformes à experiência, e isso fica evidente quando, ao finalmente estabelecer a base da moralidade no sentimento, ele afirma que, ao analisarmos o homicídio doloso,

O vício nos escapa inteiramente, enquanto considerarmos o objeto. Nunca poderemos encontrá-lo, até que voltemos nossa reflexão para nosso próprio seio, e encontremos um sentimento de censura que surge em nós com respeito a essa ação ${ }^{83}$. (HUME 31, p. 301)

É claro, portanto, que uma solução legitimamente experimental deveria, para Hume, resultar em uma moral com base no sentimento. O próprio objeto (no caso, um homicídio voluntário) não pode, pela experiência, fornecer qualquer base para a aprovação ou a censura moral. O que acontece, porém, é que, como já sabemos, o Livro 1 do Tratado já fornecera material mais do que suficiente para a recusa de uma suposta essência das coisas que seria responsável, entre outras coisas, por uma suposta instituição da moralidade, bem como uma recusa bastante contundente do próprio modo de raciocinar que era considerado válido para os racionalistas morais. No próximo capítulo veremos de que modo a concepção humiana da verdadeira filosofia a coloca como algo que deve simplesmente metodizar e corrigir aquilo que é percebido não apenas pelos filósofos, mas pelo comum dos homens. Por ora, basta que aceitemos que as bases para a recusa do racionalismo moral enquanto maneira de filosofar dependente

\footnotetext{
${ }^{83}$ The vice entirely escapes you, as long as you consider the object. You never can find it, till you turn your reflection into your own breast, and find a sentiment of disapprobation, which arises in you, towards this action.
} 
de uma razão demonstrativa que Hume se esforça para recusar já estavam postas na teoria do conhecimento humiana, o que talvez fique mais claro no capítulo seguinte ${ }^{84}$.

As teorias morais de Hobbes e de Mandeville, por outro lado, dispensaram as bases teológicas que viriam a caracterizar tanto o racionalismo moral quanto as formulações de um moralista do sentimento como Hutcheson. Partiram, como já dissemos, de um registro puramente fatual para chegar às morais do amor próprio. Se pensarmos na maneira como Mandeville estrutura seu raciocínio em boa parte da Fábula das Abelhas, partindo de análises que poderíamos dizer que antecipam a economia política tal como ela viria a ser desenvolvida não muito tempo depois e chegando, a partir delas, a uma concepção de fundamento da moralidade, podemos dizer que, ao menos enquanto parte de puros fatos para chegar à sua tese geral, ele pode ser considerado um precursor de Hume. Isso não quer dizer, é claro, que Hume possa ser considerado algo como um discípulo de Mandeville que, a certa altura, renegou seu mestre. O que acontece é que nosso filósofo aceita o ponto de partida mandevilliano, ou seja, a necessidade de se partir de uma análise do modo como as coisas se desenrolam na vida e na história para, então, a partir daí, realizar algo como uma generalização que teria por objetivo descobrir as verdadeiras bases da moralidade ${ }^{85}$. Nesse sentido, ainda que tenha em Mandeville ou mesmo em Hobbes ${ }^{86}$ adversários mais perigosos que os

\footnotetext{
${ }^{84}$ Além disso, se notarmos que as teorias morais racionalistas foram, em grande parte, desenvolvidas por grandes admiradores de Newton, como Clarke e Wollaston, a situação se torna realmente curiosa, já que eles pareceram ir muito mais longe do que seu inspirador, e de um modo do qual Hume poderia dizer que não resiste a uma análise racional mais cuidadosa. Tangenciamos, aqui, o problema de determinar a real influência de Newton sobre a filosofia de Hume, e essa é uma questão bastante controversa. Strawson e Noxon certamente exageram, senão o conhecimento que nosso filósofo possuía da física newtoniana, a admiração que ele nutria por ela. Jones, em seu Hume's Sentiments, por sua vez, levanta, com bases bastante plausíveis, a hipótese de que Hume estaria familiarizado com parte relativamente pequena da obra de Newton, entre outros motivos porque não seria capaz de dominar os aspectos mais matemáticos de boa parte de trabalhos como os Principia. De qualquer modo, o exagero cometido por Noxon não impede que aceitemos a sua afirmação, repetida algumas vezes em seu Hume's Philosophical Development, de que, no fim das contas, Hume certamente foi, em certa medida, mais fiel a Newton que muitos de seus discípulos que se mostraram tão afoitos em estabelecer um fundamento racional para a moralidade com base em relações imutáveis que Deus supostamente teria estabelecido entre as coisas.

${ }^{85}$ Ver, a esse respeito, LIMONGI 51.

${ }^{86}$ Ainda que tenhamos afirmado que Hobbes parece trabalhar de maneira distinta daquela escolhida por Mandeville, construindo modelos ao invés de partir diretamente da experiência histórica, não podemos deixar de admitir que Hobbes, ao construir sua teoria do Estado, não a assenta sobre bases teológicas, mas sobre um modelo daquilo que ele considera que é o homem. Nesse sentido, podemos afirmar que ele também procura realizar sua investigação embasado nas coisas tais como elas existem neste mundo, e recusando qualquer fundamento para a moralidade que não esteja assentado na própria natureza humana.
} 
racionalistas morais, Hume se sente à vontade em trilhar, também, o terreno exclusivamente fatual que havia sido o ponto de partida daqueles que ele chamou céticos morais.

É preciso que expliquemos, então, os motivos pelos quais escolhemos justamente um texto em que Hume critica as morais do amor próprio para tratar da maneira como a falsa filosofia aparece nos escritos morais humianos. O primeiro, bastante evidente, é justamente o fato de o Apêndice 2 da segunda Investigação oferecer, tanto por seus argumentos quanto no tom empregado pelo autor, considerações valiosas sobre o que ele considera que é a filosofia em suas formas falsas, como deixaremos claro a seguir. O segundo é justamente a necessidade que Hume tem, ao longo não apenas do Apêndice 2, mas de toda a Investigação sobre os princípios da moral, de refutar as morais do amor próprio como quem refuta não pensadores que têm por base de seus raciocínios teorias do conhecimento ou teleologias que Hume refuta em seus próprios trabalhos sobre esses temas, mas sim uma descrição, a partir simplesmente de exemplos que parecem bastante concretos, de uma moral baseada única e exclusivamente em uma certa concepção da natureza humana. E como veremos agora, se ele considera essas caricaturas "mais uma sátira do que uma verdadeira delineação ou descrição da natureza humana” e acredita que elas podem "ser um bom

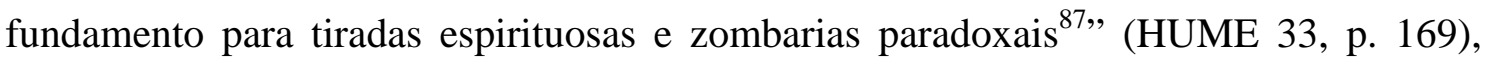
mas não considera que podem ser fonte de qualquer argumento sério, isso se deve não a certas conclusões errôneas dos defensores das morais egoístas, mas ao fato de eles serem, segundo os parâmetros humianos, maus filósofos no sentido em que sua própria maneira de filosofar tem algo que pode ser considerado no mínimo suspeito.

Ora, como já dissemos, é notável que tanto Hobbes quanto Mandeville têm a pretensão de partir da natureza humana tal como ela é. Mandeville, nesse sentido, vai além de Hobbes ao assumir como pressuposto, ao longo de toda a sua Fábula das Abelhas, uma análise econômica e social como ponto de partida para sua teoria moral, o

Se Mandeville é ainda mais perigoso, é porque parte de uma experiência direta que era dispensada por pensadores que, como Hobbes, raciocinam de maneira matemática. Esse modo de raciocinar, aliás, é o mesmo que Hume criticou ao longo do Livro 1 do Tratado e, também, da Investigação sobre o entendimento humano, de modo que parte do que dissemos sobre os racionalistas morais poderia, sem grandes problemas, ser aplicado também a Hobbes.

87 “[...] more like a satire than a true delineation or description of human nature”. 
que nos levaria a crer que ele pretende partir da experiência de maneira bastante semelhante àquela desenvolvida por Hume. Entretanto, o Apêndice 2 da segunda Investigação trata de mostrar esses dois defensores do "ceticismo moral” como autores que chegam a conclusões que não sobrevivem ao crivo da experiência. Devemos, então, explicar de que modo teria sido possível explicar de que modo pensadores que partiram de um registro meramente fatual teriam sido capazes de chegar a conclusões que desafiam a experiência. E em primeiro lugar, observamos que a resposta oferecida por Hume, definitivamente, não se dá, como talvez tenha parecido pelo que já dissemos neste parágrafo, ao modo de um falibilismo como, por exemplo, o que viria a ser esposado no século XX por Karl Popper. Como se sabe, se confiarmos no modo como os moralistas que discutimos aqui descrevem suas atividades, o que fazem ao tentar estabelecer os fundamentos da moralidade não é elaborar suas hipóteses para, depois disso, proceder de modo a “conferi-las” pelo recurso à experiência. O que fazem é, de modo, por assim dizer, baconiano, tomar a experiência como ponto de partida para quaisquer conclusões mais gerais. Nesse sentido, a acusação feita por Hume às morais do amor próprio no fim do Apêndice 2 são inegavelmente bastante graves. A passagem em que elas são apresentadas como uma sátira da natureza humana é precedida pela seguinte questão: "E que filosofia maligna deve ser essa que não permitirá à humanidade e à amizade os mesmos privilégios que são inegavelmente concedidos às paixões da inimizade e do ressentimento ${ }^{88 ”, ~(H U M E ~ 33, ~ 169) . ~ P a r a ~ n o s s o ~ f i l o ́ s o f o, ~}$ então, as morais do amor próprio não são apenas vistas como errôneas, mas como malignas. Desse modo, quando Hume observa, no terceiro parágrafo do Apêndice 2 da segunda Investigação, que, se alguém concluir, a partir das doutrinas do amor próprio, que aqueles que as pregam são pessoas desprovidas de qualquer consideração genuína pela virtude, estará enganado, ele emprega, certamente, uma ironia que, além de bastante sutil, tem potencial verdadeiramente devastador. Essa observação certamente tem, como um de seus objetivos mostrar que as morais do amor próprio são simplesmente impossíveis de ser observadas na prática. Hobbes e Epicuro, por exemplo, teriam levado vidas irrepreensíveis. Entretanto, como Hume admite, eles acreditariam na existência de sentimentos como amizade e benevolência, ainda que os considerassem refinamentos do amor próprio. Mandeville, então, parece ser mais atingido por

\footnotetext{
88 "And what a malignant philosophy must it be, that will not allow, to humanity and friendship, the same privileges, which are undisputably granted to the darker passions of enmity and resentment?”
} 
passagens como essa, ainda que ela fosse originalmente endereçada a teorias de cunho hobbesiano. Afinal, a teoria que prega que os sentimentos benevolentes são apenas um fingimento é apresentada no Apêndice 2 como estando completamente desvinculada da experiência, o que Hume também mostrará que acontece com as morais que vêem na benevolência uma forma refinada do amor próprio. É nesse contexto que o terceiro parágrafo dessa seção deve ser compreendido.

Isso é confirmado ao longo de todo o resto do Apêndice 2. Até o leitor mais descuidado é capaz de perceber que os exemplos oferecidos ao longo do texto têm por objetivo mostrar a completa incompatibilidade entre essas teorias e a experiência. As refutações são sempre em termos do que aparece mesmo aos homens comuns, e são expressas, na maior parte do tempo, como ofensivas ao senso comum. Vale lembrar que estamos falando de um autor que afirma várias vezes ao longo de seus escritos morais que os homens nunca se enganam quando o assunto são as regras morais, e que concebe a moralidade como uma normatização de convenções sociais. Não é o caso de discutirmos, aqui, de maneira detalhada a teoria moral humiana, mas certamente ela é consonante com uma filosofia que, como veremos nos capítulos seguintes, concebe-se como sistematização e correção das reflexões da vida comum. Isso é importante até mesmo porque qualquer teoria moral que pretendesse ir além desse ponto poderia ser considerada interessante para filósofos, mas não seria capaz de alcançar pessoas comuns, o que, como defenderemos no nosso quarto capítulo, Hume certamente, ao escrever a segunda Investigação, não se limitava a procurar casualmente, mas considerava uma parte importante de uma filosofia que se pretendesse verdadeira. Temos, na seguinte passagem, um bom exemplo desses apelos que Hume faz não apenas a filósofos de universidades, mas ao leitor comum:

“A cor viva e alegre de uma face não me inspira complacência e prazer, mesmo que eu tenha aprendido por meio da filosofia que todas as diferenças de compleição surgem das diferenças mais minúsculas de espessura nas partes mais minúsculas da pele, por meio das quais uma superfície é qualificada a refletir uma das cores originais de luz, e

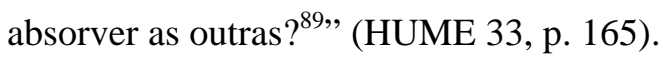

\footnotetext{
89 "Does not the lively, cheerful colour of a countenance inspire me with complacency and pleasure; even though I learn from philosophy, that all difference of complexion arises from the most minute differences
} 
De qualquer modo, parece que a ausência de preocupação em atingir as pessoas comuns não é parte do que nosso filósofo censura a Hobbes ou a Mandeville. O que o incomoda é o fato de eles, mesmo pretendendo partir da experiência para extrair suas conclusões, acabam abrindo mão disso para aderir a um princípio que lhes é particularmente caro. Incorrem em um erro que Hume denuncia na seguinte passagem de um ensaio intitulado “The Sceptic”:

Uma vez que um filósofo se tenha apossado de um princípio favorito, que talvez dê conta de muitos efeitos naturais, ele estende o mesmo princípio sobre a totalidade da criação, e reduz a ele todos os fenômenos, ainda que pelos raciocínios mais violentos e absurdos. Sendo nossa própria mente estreita e contraída, não conseguimos estender nossa concepção à variedade e à extensão da natureza, mas imaginamos que esta é tão restrita em suas operações quanto nós somos em nossa especulação $^{90}$. (HUME 37, pp. 159-60)

É verdade que devemos ser cuidadosos quando lemos esse ensaio. Como se sabe, ele deve ser entendido como parte de quatro ensaios dedicados por Hume não apenas a escolas filosóficas, mas a diferentes concepções da felicidade: “O Epicurista”, “O Estoico”, “O Platônico” e, finalmente, “O Cético”. Existem várias possibilidades de se entender o que Hume pretendia com eles, e voltaremos a esse tema posteriormente. Por ora, basta que aceitemos que, se for possível dizer que algum desses "quatro filósofos” tem a última palavra, é, sem dúvida, o cético (e também a esse ponto voltaremos mais tarde). Além disso, não podemos deixar de observar que essa afirmação sobre um “princípio favorito" nos parece tipicamente humiana, e é certamente aplicável ao caso da análise que nosso filósofo faz das morais do amor próprio. A acusação que Hume faz contra os hobbesianos e contra Mandeville é, portanto, justamente a de dispensar a experiência depois que encontraram seu "princípio

of thickness, in the most minute parts of the skin, by means of which a superficies is qualified to reflect one of the original colours of light and absorb the others?”.

90 "When a philosopher has once laid hold of a favourite principle, which perhaps accounts for many natural effects, He extends the same principle over the whole creation, and reduces to it every phaenomenon, though by the most violent and absurd reasoning. Our own mind being narrow and contracted, we cannot extend our conception to the variety and extent of nature; but imagine, that she is bounded in her operations, as we are in our speculation. 
favorito”. Fica bastante claro, então, que os filósofos do amor próprio não são maus pensadores por terem errado em suas conclusões. Eles são maus filósofos, isso sim, por terem aderido a um princípio que entrava em choque com a experiência e por procederem de maneira condenável quando se deram conta de que isso ocorria: por meio de uma "química filosófica” que exigia “o mais alto tensionamento”, tentaram forçar o mundo percebido a se enquadrar em seus raciocínios, quando deveriam ter feito o contrário. Essa é, como já havíamos adiantado, uma característica bastante importante do falso filósofo. Podemos mesmo dizer, então, que as morais egoístas são "filosofias malignas” não apenas porque pintam um quadro bastante desfavorável da natureza humana. Ainda, esse quadro não é uma sátira apenas por ser desfavorável. A malignidade em questão ocorre também porque os pensadores que a engendram, depois de elegerem um princípio que os agrade, agem como se pretendessem não explicar o mundo apresentando os princípios que podem ser observados nele, mas conseguir, por meio de seus malabarismos, que o mundo se encaixasse em seu sistema, em que reina um princípio que está longe de ser suficiente para qualquer explicação satisfatória. Não é à toa, portanto, que Hume fala, no parágrafo final do Apêndice 2 da segunda Investigação, em um privilégio que os moralistas do amor próprio concedem às paixões mais obscuras e que não é estendido às mais nobres. Essas paixões são privilegiadas porque são escolhidas como o princípio de todo um sistema moral mesmo que essa ideia rompa totalmente com o mundo percebido, e isso é, como já vimos, denunciado pelo esforço excessivo que os defensores do amor próprio têm que fazer para sustentar suas teses. Também não é à toa, então, que o cético que dá título ao ensaio afirma que, "se essa enfermidade dos filósofos [a de atribuir a um princípio favorito a explicação de todas as coisas] deve ser observada em qualquer ocasião, é em seus raciocínios referentes à vida humana ${ }^{91 ”}$ (HUME 37, p. 160). Reparemos que o cético fala, aí, em uma enfermidade dos filósofos. Além disso, o simples fato de ela ser apresentada como uma característica “padrão” entre eles basta para ilustrar o quanto ela é comum.

Deve ter ficado evidente, após esse exame da maneira como Hume lida com as morais do amor próprio, que ela oferece um terreno privilegiado para descobrirmos algumas características da falsa filosofia. Esta foi apresentada no Capítulo 1 como incapaz de resolver as contradições com as quais se defrontava ao investigar o problema

\footnotetext{
91 "[...] If ever this infirmity of philosophers is to be suspected on any occasion, it is in their reasonings concerning human life $[\ldots]$ ”.
} 
do mundo exterior. A esta altura, descobrimos que a característica essencial da falsa filosofia não é necessariamente, em toda a obra de Hume, camuflar contradições que deveria resolver. No Tratado, em que ela é discutida de maneira detalhada apenas no Livro 1, certamente temos essa impressão. Há vários motivos possíveis para que isso tenha ocorrido. Em primeiro lugar, é possível que a questão sobre o que é a filosofia tenha se tornado mais importante para Hume no decorrer de sua carreira filosófica. Isso parece bastante provável, já que esse tema se torna mais visível nos textos de maturidade de nosso autor. Outra evidência que temos a esse respeito, e que será mais trabalhada no quarto capítulo, é o fato de a própria concepção de filosofia de Hume ter passado por algumas mudanças significativas no decorrer de sua carreira, e é natural que ele tenha expressado em seus escritos o processo que levou a essas mudanças, ainda mais por elas terem ocorrido, como nossa própria análise do Apêndice 2 da segunda Investigação deve ter indicado, não apenas em função de reflexões sobre o conhecimento, mas também por suas investigações sobre outros temas. Em outras palavras, o fato de Hume passar a dar pistas de suas próprias concepções acerca da verdadeira e da falsa filosofia em textos sobre temas diversos da teoria do conhecimento é um sinal claro de que esses mesmos foram essenciais para a evolução dessas concepções.

Vejamos, então, o que nossa análise do ataque de Hume às morais do amor próprio permite afirmar sobre a evolução do que ele considerava ser a falsa filosofia. Em primeiro lugar, percebemos que ela deixa de ser necessariamente o ato, talvez involuntário, de ocultar certas contradições inevitáveis da natureza humana. É importante notarmos que ela não é apresentada nesses termos na Seção 12 da Investigação sobre o entendimento humano, que, como se sabe, foi algo como uma tentativa de reescrever a Parte 4 do Livro 1 do Tratado. Ainda assim, não há nada na Seção 12 da primeira Investigação que contradiga esse aspecto da exposição anterior da falsa filosofia. Desse modo, mesmo sendo simpáticos ao pedido de Hume para que consideremos apenas as obras posteriores ao próprio Tratado como expressões de sua filosofia, podemos supor que ele não teria por que negar essa faceta da falsa atividade filosófica. A não ser que haja outros bons motivos, podemos considerar como “renegadas” apenas as teses do Tratado que contradizem diretamente aquilo que vemos em escritos posteriores, e esse não parece ser o caso aqui. Ainda assim, a análise do Apêndice 2 da segunda Investigação nos mostra que não é preciso que a atividade 
filosófica em suas formas falsas seja sempre uma tentativa malsucedida de resolver contradições. O problema que as morais do amor próprio buscaram solucionar não é em momento algum exposto por Hume como uma contradição, apenas como um fenômeno percebido, a saber, o fato de realizarmos distinções morais, aprovando certas ações (ou caracteres) e censurando outras(os). O que há em comum entre as duas situações é que a solução proposta pelo falso filósofo não resolve o problema, apenas o camufla. A doutrina das qualidades ocultas e a da dupla existência não resolvem o problema do mundo exterior, e nem mesmo provam racionalmente que ele existe, apenas reproduzem certas ficções que poderíamos simplesmente aceitar como tais e criam modelos elaborados, mas injustificáveis racionalmente, para tentar dirimi-las. As teorias que reduzem a moralidade ao amor próprio, por sua vez, não explicam as distinções morais, mas criam uma explicação fictícia para um fenômeno que é dado pela experiência como algo irredutível à explicação proposta. Nos dois casos, um raciocínio sobre a própria experiência dada não apenas desmantelaria as soluções propostas pelos falsos filósofos como poderia conduzir à explicação correta. Concluímos, então, que a falsa filosofia, na concepção humiana, é falha por se distanciar da experiência e trabalhar enclausurada. Esse é um ponto que Hume insinua pela primeira vez no Livro I do Tratado, como veremos no capítulo seguinte ${ }^{92}$, e que, como já observamos, reaparece no ensaio “Of Essay Writing”. Parece-nos que ele também está presente no Apêndice 2 da segunda Investigação, no qual ele trata de filosofias que, independentemente dos pontos de partida que professem, estão “subordinadas” a um princípio favorito e, portanto, não poderiam de maneira alguma ser fieis à experiência. Assim, de maneira geral, podemos afirmar com segurança que a falsa filosofia não se caracteriza por camuflar contradições ou por oferecer soluções insuficientes. Essa é uma consequência de um problema anterior, que é o afastamento de uma experiência que seria justamente a única coisa capaz de providenciar o ponto de partida para qualquer filosofia que pretenda dizer algo sobre o mundo (que, como não poderia deixar de ser, é o mundo percebido).

\footnotetext{
${ }^{92}$ Não vamos desenvolver esse aspecto aqui simplesmente porque a maneira como Hume lida com a clausura da filosofia na Conclusão do Livro I do Tratado é praticamente indissociável da maneira como, logo a seguir, ele faz as primeiras considerações sobre a verdadeira filosofia como uma atividade dependente, em alguma medida, da convivência social e das propensões naturais. Consideramos que seria mais proveitoso tratar esse texto de uma só vez quando lidarmos com a concepção humiana da verdadeira filosofia.
} 
Observamos anteriormente que Hume denominou malignas as teorias morais do amor próprio. Devemos admitir que esse adjetivo não é algo que aparece todas as vezes em ele trata da falsa filosofia. Ainda assim, podemos afirmar que ele vê com bastante clareza o fato de vários pensadores se colocarem a serviço de sistemas que se desenvolvem completamente retirados da experiência para, posteriormente, realizarem esforços enormes no sentido de forçá-la a caber em filosofias que são invariavelmente fictícias. Revelar, a partir desse fato, características importantes da própria natureza humana é, sem a menor dúvida, um dos objetivos por trás das investigações de Hume sobre a falsa filosofia, como já havíamos deixado claro a tratar da seção do Tratado intitulada "Da Filosofia Antiga”. Entretanto, seria impossível deixar de notar, no diagnóstico humiano das vicissitudes que ele via acontecer entre tantos praticantes da atividade filosófica, algo como uma postura de combate. Isso ajudaria a explicar, inclusive, o motivo pelo qual a própria filosofia se tornou um tema mais presente em suas obras de maturidade. Talvez isso se explique ao menos em parte porque, como mostraremos a seguir, nosso autor percebeu que a falsa filosofia pode ter consequências perniciosas não apenas para intelectuais, mas também para o homem comum.

É verdade que, depois de tudo que foi dito até aqui, pode parecer um tanto estranho afirmar que a filosofia, quando praticada em suas formas falsas, prejudica algo além de si mesma. O que construímos até agora foi um quadro segundo o qual o falso filósofo está isolado demais da vida comum para poder ter algum impacto sobre ela. Se as coisas fossem assim tão simples, ele não seria mais que um eremita ao qual não temos por que dar atenção. Infelizmente, porém, existem evidências de que não estamos em uma situação tão segura. É claro que isso não fica claro em todos os momentos em que ele discorre sobre a natureza da própria filosofia. Na Conclusão do Livro 1 do Tratado, por exemplo, encontramos a famosa passagem em que a filosofia é preferida à religião como nossa guia em investigações sobre aquilo que escapa ao nosso mero cotidiano simplesmente por ser mais segura e agradável, já que a religião, por estar vinculada às opiniões populares, se enraíza com mais força em nossas mentes e, portanto, pode perturbar o curso normal de nossas vidas. Ainda que algumas seitas de filósofos possam levar vidas bastante estranhas por conta de seus preceitos, essa não é a 
regra. De maneira geral, para Hume, “os erros em religião são perigosos, aqueles em filosofia, apenas ridículos ${ }^{93 \%}$ (HUME 31, p. 177).

\section{Uma história de corrupção}

Não devemos nos enganar, porém, com o peso aparentemente pequeno que essa passagem poderia nos fazer supor que a falsa filosofia tem ao longo dos escritos humianos. E isso não apenas porque defenderemos, posteriormente, que a verdadeira filosofia deve ser, para nosso autor, algo que pode interferir, ao menos em alguma medida, no "mundo da conversação”. Independentemente daquilo em que apenas uma leitura do Tratado poderia nos fazer acreditar, a concepção humiana da falsa filosofia certamente permite que a vejamos como algo que pode se tornar pernicioso não apenas para aqueles que a praticam, mas para toda a sociedade, ainda que, como veremos a seguir, isso pareça ocorrer apenas em situações específicas.

Temos uma mostra bastante clara disso no diálogo que encerra a Investigação sobre os princípios da moral. Nos últimos parágrafos desse texto, Hume trata daquilo que denomina vidas artificiais. Estas surgem quando alguém busca viver não segundo aquilo que lhe dita a própria sociabilidade, mas segundo certos princípios excessivamente rígidos e descolados da vida comum. E ao se descolar da vida que compartilhariam com os outros homens, não podemos nem mesmo responder pelo que os agradará ou não. Para Hume, eles estão mesmo em um "elemento diverso" daquele em que se encontra o resto da humanidade e, mais do que isso, "os princípios naturais de suas mentes não funcionam com a mesma regularidade” que poderíamos esperar dos homens que regulam sua vida pelas máximas da vida comum ${ }^{94}$ (HUME 33, p. 199). É importante observarmos que nosso autor trata dessas vidas artificiais depois de afirmar que, na antiguidade, a religião não tinha grande autoridade sobre a maior parte das vidas daqueles que as praticavam. Os devotos tinham apenas que comparecer aos rituais e realizar os sacrifícios devidos, e esperavam que os deuses deixassem-nos decidir como seria o restante de sua conduta. À época, era a filosofia que poderia legislar sobre o

\footnotetext{
93 “[...] the errors in religion are dangerous; those in philosophy only ridiculous”.

94 “[...] They are in a different element from the rest of mankind; and the natural principles of their mind play not with the same regularity, as if left to themselves [...]".
} 
comportamento cotidiano dos homens, e era, portanto, o grande meio pelo qual alguém poderia vir a se tornar, digamos, uma pessoa distinta das demais. Hume observa, então, que, como já havíamos visto, a filosofia parece, mais recentemente, ter-se trancado em seu gabinete, cedendo espaço à religião moderna, que fiscaliza cada aspecto de nossas condutas, prescrevendo regras universais mesmo a nossos simples pensamentos.

Hume cita, então, dois exemplos disso que chama vidas artificiais, a saber, Diógenes e Pascal. A referência a Diógenes é particularmente curiosa porque, ao falar sobre possíveis exceções ao fato de a filosofia ser desprovida de segurança, o exemplo era constituído, justamente, pelos cínicos. Quanto a Pascal, parece constituir um ótimo exemplo porque, apesar de ter levado uma vida que nosso filósofo considera longe de ter sido exemplar, é visto por ele como um homem de gênio e como alguém que teria sido um homem de virtude, caso suas inclinações virtuosas tivessem podido se exercer.

O que devemos reter desses exemplos não é o curso particular de ação escolhido por Diógenes ou por Pascal. Nesse ponto, aliás, podemos observar que os dois homens eram bastante diferentes. O primeiro, como seria de se esperar de um bom cínico, teria buscado se tornar tão independente quanto possível, confinando suas necessidades à sua própria mente. Mostrava grandeza de espírito e enorme orgulho e, ao suportar as maiores austeridades, tinha por objetivo habituar-se a uma existência dura, que então poderia trilhar sem sofrimento. Entregava-se, mesmo em público, aos prazeres mais bestiais. Defendia a mortalidade da alma e tinha por seu alvo qualquer forma de superstição.

Pascal, por outro lado, procurava não perder de vista sua dependência do Criador, além de nunca esquecer suas imperfeições. Fazia constantes profissões acerca de quanto era desprezível e abraçava as condições mais duras simplesmente para "sofrer tanto quanto possível”. Recusava qualquer prazer, por mais inocente que fosse. Era dirigido, em todos os assuntos, pela superstição mais ridícula e por um enorme desprezo por esta vida, ao menos em comparação com uma próxima.

Vemos, então, que o que importa não é achar características particulares que podem fazer com que haja concordância entre a conduta desses dois filósofos; isso seria praticamente impossível. O que os une, no que diz respeito ao problema de que tratamos aqui, é o fato de terem vivido de maneira completamente determinada não pela própria vida comum, pela moral que, para Hume, se desenvolve naturalmente a partir da 
expansão da simpatia, mas por princípios totalmente descolados dela. Isso não quer dizer, é claro, que qualquer filósofo que defenda princípios distantes da vida comum estará condenado a levar uma vida artificial. No Apêndice 2 da segunda Investigação, Hume admite que Hobbes, por exemplo, não havia levado uma vida condenável, apesar de defender que o amor próprio era o fundamento real da moralidade. Entretanto, vimos que, na modernidade, a filosofia havia cedido à religião o papel de guia da conduta. E mesmo na antiguidade, os falsos filósofos não teriam se convertido em algo excessivamente perigoso por haver um número considerável de seitas que simplesmente não eram capazes de converter umas às outras e que, além disso, deviam conviver em uma sociedade livre (HUME 37, pp. 120-1). A religião, por sua vez, não era necessariamente perigosa no início (o que não quer dizer que não tenha gerado problemas em caso algum). Porém, tornou-se inegavelmente perniciosa quando começou a operar estreitamente ligada à falsa filosofia.

Essa parece ser uma das lições centrais da História natural da religião. Apesar de ser relativamente pouco lida, ela é o texto em que Hume trata da religião tal como ela realmente se dá no mundo, em oposição ao modo como ele acerta contas com o teísmo filosófico (o que faz, como sabemos, nos Diálogos sobre a religião natural ${ }^{95}$ ). E para nosso filósofo, as primeiras manifestações religiosas teriam ocorrido sob a forma do politeísmo. Entre os motivos que Hume assinala para essa teoria, está o fato de que os homens mais primitivos teriam sido simplesmente incapazes de conceber a noção de um deus perfeitamente simples e uno. Outra propensão que influenciaria as concepções religiosas dos antigos seria aquela segundo a qual os homens tendem a atribuir características humanas a objetos inanimados. Daí termos antigos pagãos acreditando em hamadríades (deusas de rios) ou em gênios ocupando certos bosques. Finalmente, e esse é certamente o ponto mais importante para entendermos a imbricação da falsa filosofia com o teísmo, Hume nos apresenta o fato de os homens antigos terem visto seus deuses não como explicações da origem do mundo, mas como entidades que deveriam suprir carências e afastar objetos que eram considerados temíveis. Isso resultaria em uma relação curiosa das pessoas com seus deuses. Os chineses, por

\footnotetext{
${ }^{95}$ A diferença entre essas duas maneiras de tratar a religião é marcada pelo próprio Hume na Parte 12 dos Diálogos, no momento em que Filo, apesar de sua controversa concessão a Cleantes, observa que a maior parte dos homens não assente à religião por meio de princípios racionais, mas por princípios como medo e esperança. Ora, é precisamente esse o tipo de tese que Hume desenvolve na História natural da religião.
} 
exemplo, tinham o hábito de bater em seus ídolos quando suas preces não eram atendidas (HUME 39, pp. 38-9). Os Lacedemônios, em períodos de guerra, faziam suas petições aos deuses de manhã, bem cedo, para garantir que os deuses já teriam se comprometido com eles e não concederiam qualquer favor a seus inimigos (HUME 39, p. 41).

O monoteísmo, entendido não apenas como a doutrina segundo a qual haveria um só deus, mas também como aquela segundo a qual ele é o autor de toda a natureza, é apresentada por Hume como sendo muito antiga. Ainda assim, os princípios responsáveis por seu surgimento são apresentados na História natural da religião como sendo os mesmos que teriam originado o politeísmo. Ainda que nesse texto, por motivos estratégicos (ou por política de relações públicas), o teísmo filosófico ainda permaneça como alternativa viável, os motivos pelos quais o vulgo acredita em um criador onipotente não incluem argumentos prodigiosos acerca do ajustamento de todas as coisas na natureza aos fins que elas devem exercer. Se perguntarmos a um homem comum por que ele acredita em um deus onipotente,

Ele lhe contará sobre a morte súbita e inesperada de uma pessoa, da queda e dos ferimentos de outra; da seca excessiva desta estação, do frio e das chuvas de outra. A tudo isso ele atribui a operação imediata da providência, e tais eventos, que para bons raciocinadores, são as principais dificuldades em admitir uma inteligência suprema, são, para ele, os únicos argumentos para ela ${ }^{96}$. (HUME 39, p. 50)

Hume quer fazer parecer que, na História natural da religião, o teísmo filosófico como uma saída possível para se justificar a crença em um deus onipotente. Ainda que isso não seja necessariamente verdade para “bons entendedores”,

\footnotetext{
96 "He will tell you of the sudden and unexpected death of such a one: The fall and bruise of such another: The excessive drought of this season: The cold and rains of another. These he ascribes to the immediate operation of providence: And such events, as, with good reasoners, are the chief difficulties in admitting a supreme intelligence, are with him the sole arguments for it”.

${ }^{97}$ No artigo "Hume’s Natural History of Religion”, Lívia Guimarães mostra que, na verdade, a História natural da religião tem por um de seus propósitos justamente mostrar que o teísmo não tem fundamentos muito melhores que os do politeísmo. Efetivamente, não temos como negar que, ainda que essa afirmação possa parecer pesada, mesmo que nesse texto Hume pareça mais interessado em criticar as religiões populares, há vários motivos que permitem entrever, contra os supostos elogios de Hume ao teísmo essencialmente filosófico, que o autor não o considera sustentável. Exemplos mostrados por Guimarães incluem: 1. O fato de Hume afirmar que não é natural ou óbvio presumir que um efeito é resultado de várias causas, mas citar, posteriormente, o contra-exemplo da estátua de Laocoonte (antecipando, assim,
} 
ponto de vista será criticado de maneira mais explícita apenas nos Diálogos sobre a religião natural, que, como sabemos, foi publicado apenas postumamente ${ }^{98}$, e do qual trataremos posteriormente. Por ora, basta-nos mostrar que a lógica do medo e das necessidades, que é justamente aquela responsável pela emergência do politeísmo, também funciona para garantir que a maioria dos homens acredite em uma religião monoteísta. Isso passaria a acontecer a partir do momento em que um entre os vários deuses passa a ser vistos como mais importante que os demais, até que os homens passam atribuir a ele a condição de único deus, além de considerá-lo infinitamente poderoso e capaz de decidir, sozinho, sobre o bem e o mal de todos os homens. Isso gera um efeito bastante curioso, que é denominado por Hume fluxo e refluxo entre politeísmo e teísmo. Isso ocorre na medida em que a ideia de um deus único e infinitamente perfeito é demasiadamente refinada para a compreensão da maioria dos homens, que passam a recorrer a algo como mediadores entre eles próprios e seu deus. Com o tempo, esses mediadores passam a adquirir cada vez mais importância, até por estarem mais próximos da natureza humana e, assim, poderem ser concebidos com maior vivacidade. Porém, isso faz com que a religião que voltou a ser idólatra se torne cada vez mais grosseira, o que a leva de volta ao monoteísmo quando as representações excessivamente vis dos deuses (os que antes eram apenas intermediários) passam a não ser mais satisfatórias. De qualquer maneira, é possível que os sacerdotes tenham certo controle sobre esse retorno ao politeísmo. Um exemplo sobre como esse controle pode ser efetuado é o modo como os muçulmanos proíbem as artes da escultura e da pintura, não permitindo que elas sejam empregadas para representar nem mesmo figuras humanas $^{99}$.

um dos exemplos citados por Filo nos Diálogos); 2. Hume associa o politeísmo a eventos humanos e o teísmo a uma contemplação serena da natureza, mas, na Seção 2, mostra que o politeísmo se inspira também em fenômenos naturais, ao menos parcialmente; 3. A observação de que causas minúsculas, as quais dão conta de todos eventos que os politeístas atribuem aos deuses, podem ser estendidas logicamente também ao teísmo, caso o universo seja perfeitamente mecânico.

${ }^{98}$ Na verdade, os Diálogos correram grande risco de não serem publicados. Tanto Strahan, que era o editor da obra de Hume na época, quanto Adam Smith, a quem Hume confiou uma cópia para que ele se encarregasse da publicação se Strahan se abstivesse, terminaram por se recusar a fazer com que a obra viesse à luz. Apenas um sobrinho, a quem Hume também havia confiado uma cópia, se aventurou a garantir que a obra fosse, enfim, publicada. Isso reforça a ideia de que os Diálogos tinham um potencial bastante explosivo na época. Assim, não é difícil compreender por que Hume parece aceitar, na História natural da religião, ao menos a possibilidade de o teísmo filosófico ser algo viável.

${ }^{99}$ Cf. HUME 39, p. 58 
Devemos, agora, concentrar-nos no que Hume tem a dizer sobre certos aspectos particulares do teísmo. Como já vimos, ele é aceito pela maior parte dos homens devido à mesma lógica do medo que havia sido responsável pelo florescimento da idolatria. Esse é um ponto bastante importante para nosso autor, que trata de reforçá-lo em várias passagens. $\mathrm{O}$ fato de o medo e a satisfação de várias necessidades ser aquilo que leva os homens à religião, além disso, é exposto por Filo na Parte XII dos Diálogos sobre a religião natural, em uma passagem em que não seria nada precipitado afirmar que essa personagem fala pelo próprio Hume. Ainda assim, como não poderia deixar de ser, o teísmo tem uma série de diferenças importantes com relação ao politeísmo. A primeira que nos interessa aqui é o fato de ele ser, por definição, menos tolerante. Ora, vejamos: o politeísmo, por estar fundado em histórias tradicionais, tem a desvantagem de que “qualquer prática ou opinião, por mais bárbara ou corrupta que seja, pode ser autorizada por ele, e o maior espaço ser deixado para que a velhacaria se imponha sobre a

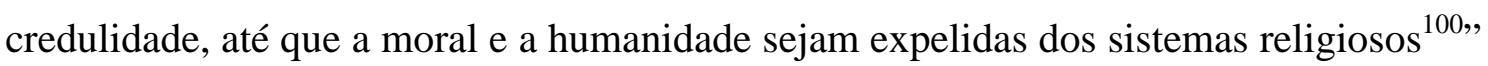
(HUME 39, pp. 58-9). Ainda assim, inseparável desse inconveniente, está uma inegável vantagem, a de que, por considerar limitados os poderes e as funções das divindades, um povo politeísta tende a reconhecer a divindade dos ídolos de outras nações e, no fim das contas, considerar os rituais de outros povos compatíveis com os seus próprios. No caso do monoteísmo, as coisas acontecem em sentido inverso. Por um lado, ao permitir um só deus, considerado o extremo da perfeição e da bondade, ele tende, caso seja seguido de maneira justa, a banir da religião todas as coisas fúteis, insensatas ou desumanas, além de se tornar um ótimo exemplo para todos os homens. Entretanto, inseparável dessa qualidade, está o fato de a devoção a um só deus implicar a consideração de que todos os outros são completamente absurdos. Mais do que isso, diz Hume, "essa unidade do objeto parece requerer naturalmente a unidade da fé e das cerimônias, e fornece àqueles que o desejam um pretexto para representar seus adversários como profanos, e objetos da vingança tanto divina quanto humana ${ }^{101 \text {, }}$ (HUME 39, p. 59). Em suma, é simplesmente impossível que o monoteísmo não seja

\footnotetext{
100 " [....] any practice or opinion, however barbarous or corrupted, may be authorized by it; and full scope is left for knavery to impose on credulity, till morals and humanity be expelled from the religious systems [...]".

101 “[...] this unity of object seems naturally to require the unity of faith and ceremonies, and furnishes designing men with a pretext for representing their adversaries as prophane, and the subjects of divine as well as human vengeance.
} 
intolerante. É consequência inevitável, quando aceitamos a existência de um único deus, que consideremos todos os outros como falsos e, é claro, que os seguidores dessas outras entidades sejam vistos como agentes que pretendem corromper os seguidores do único deus, por assim dizer, verdadeiro.

A esse aspecto soma-se um outro, que colabora para que o teísmo acabe por se tornar uma monstruosidade: a própria união entre ele e a filosofia. Isso ocorre porque o teísmo, visto apenas como o princípio fundamental de uma religião popular, parece bastante sensato. Assim, mesmo que boa parte dos dogmas esteja contido em um livro sagrado, ou que seja ditado por uma autoridade visível (digamos, o papa), ele ainda será mais aceitável para mentes com inclinações mais especulativas, ainda mais quando inculcado desde a infância. Até aí, parece não haver grandes problemas. É natural que mentes especulativas (e, portanto, filósofos) dêem seu assentimento a doutrinas que parecem consistentes e sensatas. O problema é que as aparências do teísmo terminarão por se mostrar completamente enganadoras. Entretanto, nesse ponto, já não será possível que a filosofia colabore no sentido de regular os princípios que se mostrem incorretos. Ao invés disso,

[...] a filosofia logo se encontrará, de maneira muito desigual, sob o jugo de sua nova associada e, ao invés de regular cada princípio, à medida em que elas avançam juntas, ela será, a cada momento, pervertida para servir aos propósitos da superstição. Pois além das incoerências inevitáveis que devem ser reconciliadas e ajustadas, poder-se-ia afirmar seguramente que todas as teologias populares, especialmente a escolástica, têm um certo apetite pelo absurdo e pela contradição $^{102}$. (HUME 39, p. 65)

Afinal, caso não se pusesse além da razão e do bom senso, a teologia simplesmente pareceria fácil demais, familiar demais. É preciso que ela recorra ao mistério e à obscuridade. Esse, alias, é um fato que pode ser confirmado pela própria história eclesiástica. Todas as disputas ocorridas ao longo dela são vistas por Hume como situações em que o bom senso está condenado a perder. Além disso, as heresias

\footnotetext{
102 “[...] philosophy Will soon find herself very unequally yoaked with her new associate; and instead of regulating each principle, as they advance together, she is at every turn perverted to serve the purposes of superstition. For besides the unavoidable incoherencies, which must be reconciled and adjusted; one may safely affirm, that all popular theology, especially the scholastic, has a kind of appetite for absurdity and contradiction”.
} 
são sempre apresentadas como doutrinas providas de bom senso (e, portanto, de razão comum). Quanto à filosofia, não pode contrariar os princípios teístas, ou "os mesmos fogos que foram acendidos para os hereges servirão também para a destruição dos filósofos ${ }^{103 »}$ (HUME 39, p. 66).

Não queremos, evidentemente, transmitir a impressão de que o teísmo necessariamente se imbrica com a filosofia e faz dela sua criada. A História natural da religião apresenta alguns exemplos em que esse definitivamente não é o caso. Os getes, por exemplo, são apresentados como teístas e unitarianistas, mas não como filósofos (HUME 39, p. 56). O mesmo pode ser dito dos seguidores de Zoroastro. Parece, então, que Hume, ao falar do modo como filosofia e religião se corrompem mutuamente, refere-se, sobretudo, ao cristianismo europeu, que, a partir da Idade Média, teria se tornado cada vez mais filosófico ${ }^{104}$, bem como às outras duas grandes religiões monoteístas ocidentais. De qualquer maneira, fica estabelecido que o que ocorre com filosofia e religião quando elas se unem é que a primeira é reduzida ao papel de criada e passa a reconciliar as inúmeras (e inevitáveis) contradições do discurso religioso. Desse modo, passa a colaborar com uma instituição que se caracteriza pela intolerância e pela perseguição. Além disso, por se tornar subordinada a uma instituição que a colocará em um papel meramente justificador, é natural que a filosofia passe, então, a ignorar aquilo que o bom senso e a experiência proporiam como sensato. Isso é inevitável porque, caso o filósofo não aceite essa tarefa, certamente será jogado à fogueira. Fica, então, evidente o engendramento de uma forma falsa da atividade filosófica que fatalmente se descolará da experiência e passará a produzir inverdades que colaborarão com perseguições e, em

\footnotetext{
103 "[...] the same fires, which were kindled for heretics, will serve also for the destruction of philosophers".

${ }^{104}$ A História da Inglaterra nos fornece alguns bons exemplos nesse sentido. Henrique VIII, por exemplo, como vemos no Volume III, teria escrito, antes de sua cisão com a Igreja Católica, um volume contra os protestantes de caráter teológico, o que teria garantido para ele grande aprovação do papa. Além disso, teria chamado um suposto herege para discutir com ele assuntos religiosos. Ainda que essa discussão tenha se dado em situação de completa desigualdade, o simples fato de ela ter ocorrido mostra que, no reinado desse monarca, discussões teológicas eram algo importante. Não só isso não teria sido possível sem que a religião tivesse adquirido um caráter filosófico como a própria teologia é, por si só, resultado da imbricação que discutimos aqui. Fosse a religião católica algo baseado apenas em histórias tradicionais, não haveria qualquer razão de ser para a teologia.
} 
certos casos, poderão colaborar para o surgimento das tais vidas artificiais que Hume tanto critica ${ }^{105}$.

Existe ainda um outro aspecto que faz com que a subordinação da filosofia ao discurso religioso seja extremamente prejudicial. Ainda que, em algum momento, a religião tenha sido capaz de conter certos ímpetos e colaborar com a moralidade ${ }^{106}$, isso só é possível em povos que Hume trata de classificar como primitivos e, além disso, bastante crédulos e indolentes. A regra geral é que a religião popular é prejudicial à moralidade. Isso porque os devotos tendem ver como naturais as boas ações que realizam como pais ou como amigos e, nessas situações, o próprio sentimento de virtude basta para que ajam de maneira correta. O supersticioso, porém, não vê nas ações benevolentes um caminho para contentar seu deus, que ele acredita poder agradar somente por meio dos ritos apropriados. Mesmo grandes crimes não são incompatíveis com uma grande fé religiosa, já que mesmo o remorso mais horroroso apenas levará os supersticiosos a executar certos rituais que, acreditam eles, garantirão que a divindade os perdoe. E mesmo os padres, ao invés de corrigir esse tipo de defeito, talvez prefiram encorajá-lo, já que com isso poderão assegurar a fartura de seu rebanho (HUME 39, pp. 89-91) $)^{107}$. Sistemas como a venda de indulgências, desse ponto de vista, não são um inconveniente desta ou daquela religião, mas um exemplo claro de algo que é consequência natural da própria instituição religiosa.

Como já vimos, não é possível que a filosofia tenha um papel de grande destaque quando falamos em convencer o povo da verdade das afirmações de cunho religioso, já que ele aceita a religião pela mesma lógica do medo que caracteriza as crenças politeístas. Ainda assim, ela pode colaborar, mesmo aos olhos dos incultos, para

\footnotetext{
${ }^{105}$ Assim sendo, pelo menos no que diz respeito ao teísmo, parece bastante viável a leitura que Jennifer Herdt faz das considerações religiosas da filosofia humiana quando aplicadas à sua filosofia moral e a seus relatos históricos. Nesse aspecto, a tese de Herdt é que as diferentes religiões, por colocarem sistemas fechados em oposição à moralidade desenvolvida socialmente a partir da simpatia, são sempre causa de facciosidade. Essa conclusão nos parece inevitável quando lemos os textos de Hume que versam sobre temas religiosos.

${ }^{106}$ Exemplos práticos desse fato são oferecidos, também, na História da Inglaterra. Cf. HUME 40 vol. II, p. 14; HUME 38 vol. II, p. 137.

${ }^{107}$ Esse ponto é defendido por Hume também na Parte 12 dos Diálogos sobre a religião natural. Mesmo que não admitamos que apenas Filo é representante do pensamento humiano nessa obra, não podemos deixar de observar que, mesmo que seja ele a falar sobre a má influência da religião na moral, seus argumentos não são respondidos por Cleantes e parecem reter até o fim a sua pujança.
} 
a conciliação de contradições. Além disso, ao ser subjugada pelo teísmo, ela certamente colabora para que ele adquira a forma que melhor lhe aprouver e, é claro, colabora para que debates entre eclesiásticos adquiram esta ou aquela forma, influenciando, assim, as doutrinas que serão posteriormente expostas ao povo. Portanto, não há como negar que a filosofia, ao tornar-se criada da religião, torna-se também cúmplice de doutrinas que não apenas se abstêm de impedir que os homens se tornem maus, como, em ao menos parte dos casos, podem colaborar para que isso aconteça. Isso nos leva a concluir a História natural da religião tem como um de seus grandes ensinamentos acerca da natureza da própria filosofia é que esta, em suas formas falsas, não tem seus efeitos nocivos restritos apenas à esfera dos enganos teóricos que poderiam ser considerados inofensivos para o homem comum. Aliada à religião (e, com isso, alienada do mundo da experiência e da sociabilidade), a falsa filosofia torna-se, como Hume considera que não poderia deixar de ser, parceira da intolerância, bem como de atos que colaboram para perverter não apenas filósofos e padres, mas todos os homens.

Nesse sentido, pode parecer que Hume é, em ao menos alguma medida, mais simpático ao politeísmo, que está embasado apenas em histórias tradicionais. Quanto aos enganos referentes a criaturas que habitam fontes e bosques, podem ser explicados por características da natureza humana fáceis de reconhecer, como a tendência a atribuir características humanas a objetos inanimados. Além disso, as tradições politeístas consideram que "os mesmos poderes ou princípios, quaisquer que tenham sido eles, que formaram este mundo visível, os homens e os animais produziram também uma espécie de criaturas inteligentes, de substância mais refinada e de maior autoridade que as

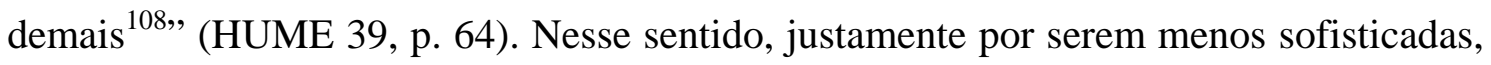
as tradições politeístas não têm a enorme tendência ao absurdo e à obscuridade que invariavelmente caracteriza o teísmo popular contaminado pela filosofia. Além disso, o politeísmo, justamente por estar embasado apenas em narrativas tradicionais, poderia ser considerado parte de um sistema social construído com base em um princípio da

\footnotetext{
108 “[...] the same powers or principles, whatever they were, which formed this visible world, men and animals, produced also a species of intelligent creatures, of more refined substance and greater authority than the rest $[\ldots]$ ".
} 
natureza humana que, via de regra, opera na constituição de qualquer sociedade, ou seja, a expansão da simpatia ${ }^{109}$.

Essa aparente simpatia pelo politeísmo, entretanto, exige certa cautela. Afinal, ainda que Hume considere certas ficções como perdoáveis quando acontecem entre as crianças ou entre os primitivos, isso não quer dizer que elas deixem de ser ficções que, em outros casos, deveriam ser evitadas. Em outras palavras, a crença em ninfas ou hamadríades não está no mesmo patamar que, por exemplo, aquela em objetos externos. Se Hume é mais generoso com o politeísmo, não é porque o considera mais “verdadeiro" que o teísmo ${ }^{110}$, mas sim porque, além de mais tolerante (e, portanto, mas “sociável”), ele é menos danoso à moral que o teísmo, ainda mais quando este último vem acompanhado da filosofia.

Existe, ainda, a esse respeito, um outro ponto que devemos considerar. Logo no início do primeiro volume de sua História da Inglaterra, Hume faz uma apresentação nada generosa dos druidas, caracterizando-os como sacerdotes que governavam com rédeas curtas seus seguidores, os quais eram mantidos em um estado de terror constante. Os ritos druídicos, segundo o texto, seriam praticados em bosques escuros e outros lugares misteriosos e incluiriam, entre outras coisas, sacrifícios ${ }^{111}$. Além disso, o povo que seguia essa religião, composto pelos primeiros habitantes da Inglaterra, é caracterizado como ignorante e um tanto preguiçoso. Existem vários motivos pelos quais Hume faz essa caracterização, e nem todos eles têm a ver com suas considerações sobre assuntos religiosos. Na verdade, boa parte dos motivos que levam a essa caracterização ficam bastante evidentes quanto percebemos o tipo de teórico da sociedade que nosso filósofo pretende ser, e trataremos disso de maneira detalhada no

\footnotetext{
${ }^{109}$ Nesse aspecto, nossa avaliação do modo como Hume vê idolatria e teísmo não seria muito diferente daquela apresentada por Donald Livingston no quinto capítulo de seu Philosophical Melancholy and Delirium se o único texto humiano que menciona religiões politeístas fosse a História natural da religião. Entretanto, como se sabe, Hume não é tão generoso com o politeísmo em outras obras, como o Volume I da História da Inglaterra, e isso é algo que Livingston parece ignorar estrategicamente.

${ }^{110}$ Nesse sentido, o que se pode dizer é que a História natural da religião, pelo contrário, já permite entrever que, para Hume, o teísmo não é, de maneira alguma, mais bem fundamentado que o politeísmo. Não nos deteremos sobre esse tema, já que ele fugiria ao escopo do que estamos tentando mostrar aqui, mas convém indicarmos que a intenção de Hume parece ser justamente partir da exposição do politeísmo como algo infundado para mostrar que, no fim das contas, o politeísmo não é lá muito melhor. De qualquer maneira, a esse respeito, ver GUIMARÃES 26.
}

${ }^{111}$ Cf. HUME 40 vol. I, p. 6. 
quarto capítulo deste trabalho. Por ora, basta que observemos que o politeísmo é elogiado não por sua maior verdade ou por estar presente em povos mais dignos de elogio, mas sim porque ele é inseparável do registro tradicional que constitui, como veremos posteriormente, a maneira natural pela qual se deve dar, ao menos para Hume, a formação de qualquer sociedade. O teísmo, por sua vez, merece reprimendas mais duras porque, além de sua preferência pela constituição de conceitos absurdos, pode contribuir para a formação de homens viciosos e porque tem como resultados naturais as perseguições e as fogueiras que vemos, por exemplo, ao longo de boa parte do volume III da História da Inglaterra. Além disso, demos atenção especial ao teísmo simplesmente porque era importante mostrarmos que, ao se associar a ele, a filosofia se torna comparsa de todos os efeitos nefastos que dele possam advir. Como trataremos de mostrar posteriormente, se o verdadeiro filósofo trata da religião, é apenas para mostrar que, além de a filosofia não poder se misturar a ela, simplesmente não tem (e, mais do que isso, não deve ter) nada a dizer sobre qualquer possível divindade.

\section{A evolução do conceito de falsa filosofia}

No capítulo anterior, as formas falsas da atividade filosófica haviam sido apresentadas simplesmente como construções incapazes de resistir a um exame racional profundo. Neste, por outro lado, vimos que a falsa filosofia é vista por Hume, também, como algo capaz de promover males bastante consideráveis não só nas vidas dos falsos filósofos, mas, em alguns casos, na sociedade como um todo. Convém, então, a título de esclarecimento, mostrarmos que isso não é fruto de uma contradição ou qualquer coisa desse tipo.

O primeiro capítulo deste trabalho tratava apenas da falsa filosofia tal como ela é mostrada no Tratado da natureza humana, mais especificamente, na Parte 4 do Livro 1. Isso era importante por ser nesse texto que Hume discorre, pela primeira vez, sobre aquilo que considera as formas falsas da atividade filosófica. Já este capítulo teve como base textos posteriores do autor. Como ficará evidente nos capítulos seguintes, sua própria concepção de filosofia passou por algumas mudanças ao longo de sua carreira. Se o Tratado era destinado ao público erudito, como fica evidente desde a Introdução, não se pode dizer o mesmo dos textos posteriores de Hume. Como veremos posteriormente, isso se deve ao fato de ele ter passado a considerar a filosofia como algo 
que poderia colaborar efetivamente para a formação (principalmente no sentido moral) de uma parcela da população que, se não era composta pela maioria, certamente era mais ampla que o número de doutores das universidades. E se é assim, é bastante natural que a filosofia humiana tenha passado a ver em suas adversárias fatores que poderiam causar prejuízo àqueles que a verdadeira filosofia deveria buscar atingir.

Além disso, por mais que as consequências para a religião dos princípios expostos no Tratado fossem certamente bastante devastadoras, Hume só trouxe ao primeiro plano os problemas referentes a ela em seus escritos posteriores ${ }^{112}$. Na verdade, parece que a religião ganhou cada vez mais espaço na temática humiana, se considerarmos que ela aparece como um tema importante em todos os escritos posteriores do filósofo escocês, além de ter "ganhado" duas obras dedicadas exclusivamente a ela. Se levarmos em conta que a junção de religião e filosofia é algo visto como bastante pernicioso por Hume, não é complicado enxergar, aí, mais um motivo pelo qual ele teria passado a ver as formas falsas da atividade filosófica como algo pernicioso, e não como algo que engendraria erros “apenas ridículos”.

Essas duas considerações deixam entrever, de qualquer maneira, que a filosofia passou a ganhar, nos escritos posteriores de Hume, o estatuto de algo que se relaciona de algum modo a um público mais amplo e, talvez, à própria vida pública, já que filósofos de todos os tipos tratarem de temas como o estado e o lugar que a religião deve ocupar nele. Nesse sentido, parece impossível separar o falso filósofo dos efeitos que ele tem sobre a sociedade, e isso abriu espaço para que Hume se dedicasse a analisá-lo não apenas como aquele que comete enganos, mas como aquele que é, em certa medida, o inimigo de um certo modelo de sociabilidade. Ao se desligar por completo da experiência comum, o falso filósofo torna-se o responsável pelo surgimento de esquemas corrompidos de moralidade, vidas artificiais. Além disso, ele próprio passa a ser visto como um pervertido, na medida em que raciocina por meios que são (como ficará mais claro no capítulo seguinte) ininteligíveis, escolhe seus princípios baseado em mero favoritismo (e depois só pode tentar forçar o mundo percebido a se encaixar

\footnotetext{
${ }^{112}$ Havia, na versão preliminar do Tratado, uma seção sobre milagres que, acredita-se, era do mesmo teor daquela que apareceu, posteriormente, na Investigação sobre o entendimento humano. Entretanto, Hume a retirou do texto que foi encaminhado para publicação. Isso, entretanto, não desmerece nossa posição, já que parece que a religião era um tema que, ainda que fosse tocado por vários pontos da obra de estréia de Hume, só recebeu um tratamento realmente detalhado posteriormente, e isso não mudaria com o acréscimo de uma única seção.
} 
em seus princípios) e, é claro, ataca ferozmente tudo aquilo que não apenas o verdadeiro filósofo, mas qualquer homem sensato poderia considerar como natural.

Essas considerações perpassam todos os temas de que tratamos ao longo deste capítulo. Ao considerarmos a crítica feita por Hume às morais do amor próprio, o que estava em questão era, o tempo todo, o modo pelo qual o falso filósofo opera sua “química filosófica”. Nosso objetivo era, como deve ter ficado evidente, mostrar a falsa filosofia não como simples erro, mas como resultado de uma atitude que consiste na recusa do mundo que é o único ponto de partida tanto para o filósofo quanto para o vulgo e na adesão aos "princípios favoritos” a que fizemos referência. Posteriormente, buscamos expandir nosso tratamento da atividade filosófica em suas formas falsas tentando compreender os efeitos que ela pode exercer, ao menos em casos específicos, não apenas sobre aqueles que a praticam, mas, também, sobre sociedades inteiras, ao menos em casos mais desafortunados. Podemos concluir, então, que o quadro da falsa filosofia pintado ao longo das obras de Hume referentes, deixa de ser, nos escritos posteriores ao Tratado, apenas a imagem de um conjunto de erros cometidos por pensadores atrapalhados. Podemos afirmar que, a partir de um dado momento, o falso filósofo, de acordo com o tratamento que a filosofia humiana confere a ele, passa a assemelhar-se, isso sim, a um monstro. 
PARTE II 


\section{CAPÍTULO III}

\section{QUE CONHECIMENTO?}

Dedicamo-nos, até o momento, a mostrar aquilo que consideramos que é, no pensamento de David Hume, a falsa filosofia. Tratamos de mostrar que ela é um conceito que aparece ao longo de praticamente toda a obra de Hume, mesmo em textos dedicados a outros temas que não a própria atividade filosófica. Mostramos, ainda, que a falsa filosofia ocorre sempre que qualquer pensador se descola da experiência que compartilha com o homem comum em nome de certos "princípios favoritos", criando um mundo de ilusão ao qual ele pretende que o mundo real se conforme. Por fim, deixamos claro que, ainda que no Tratado da natureza humana, as reprimendas aos falsos filósofos fossem de cunho mais teórico, o restante da obra de Hume mostra um pensador que viu na falsa filosofia algo que revela uma perversão e, em certos casos, pode ser pernicioso não apenas àqueles que a praticam, mas à sociedade como um todo. Ele indica, ainda, alguns motivos que podem colaborar para explicar mudanças na maneira de se relacionar com seus adversários que praticavam essas filosofias que ele considerava não apenas errôneas, mas efetivamente más. É chegada, então, a hora de tentarmos explicar aquilo que Hume considera que a filosofia deve ser, e é desse problema que trataremos neste capítulo e no próximo. Por enquanto, deter-nos-emos em considerar a concepção humiana da verdadeira filosofia do ponto de vista da teoria do conhecimento. Posteriormente, no capítulo seguinte, trataremos de observar o que as análises que Hume empreende sobre a própria filosofia e sobre alguns outros temas permitem observar no que diz respeito ao tema que nos interessa. Isso será importante não apenas porque nos permitirá ver em prática certos princípios que exporemos neste capítulo, mas porque a partir dos escritos humianos sobre moral e sobre (por assim dizer) a cultura será possível apreender informações importantes que nos permitirão elucidar mais alguns aspectos da concepção de filosofia que Hume realmente defendeu, além de estabelecer em bases consideravelmente mais sólidas a relação entre a verdadeira filosofia e o senso comum. 
Vimos afirmando, desde a Introdução, que é na Parte 4 do Livro 1 do Tratado que Hume discute pela primeira vez, de maneira mais explícita, a natureza da própria atividade filosófica. Também já deixamos claro que é na Conclusão do Livro 1 que Hume expõe pela primeira vez, de modo bastante geral, o modo como ele entende que a filosofia se dá em sua forma verdadeira. Parece bastante natural, então, que nos voltemos, antes de qualquer coisa, para essa seção. Isso, porém, não basta. Certamente terminaremos por recorrer, nessa primeira exposição, à Introdução do Tratado e a passagens da Investigação sobre o entendimento humano. Depois disso, deveremos examinar certos pontos cruciais da teoria do conhecimento humiano, como a explicação da relação de causa e efeito oferecida por nosso autor, além de fazermos mais algumas considerações sobre a maneira como ele explica a crença na existência de objetos exteriores. É importante que fique claro que não teremos como alvo primário a própria relação de causa e efeito ou a própria existência do mundo exterior. Trataremos dessas questões porque elas serão importantes para que possamos tentar oferecer uma solução satisfatória ao problema “o que é a filosofia para Hume?”. Por fim, abordaremos o problema de como o verdadeiro filósofo deve tratar de questões relativas à existência da divindade. Como veremos, não restará quase nada que o filósofo poderá afirmar positivamente sobre ela. Este último problema será importante não apenas por deixar mais claros certos limites daquilo que Hume considera o método filosófico por excelência: será útil, também, para explicar por que, excluídos os Diálogos sobre a religião natural, o único modo pelo qual o nosso autor trata as questões religiosas é como um fenômeno que pode ser explicado segundo certos princípios da natureza humana.

\section{A experiência como salvação}

Se é na Conclusão do Livro 1 do Tratado da natureza humana que Hume discute pela primeira vez não aquilo que é a experiência, ou qual a concepção de razão a que recorre, mas o que é para ele a própria filosofia, parece sensato que façamos uma leitura bastante atenta dessa seção. Em seu início, ele afirma que, antes de se atirar às “imensas profundezas de filosofia” que tem diante de si, convém parar por alguns instantes e analisar a situação em que se encontra (HUME 31, p. 171). Em outras palavras, antes de tratar de problemas relacionados às paixões, à moral, à política e, 
talvez, outros mais, Hume pretende conferir de que maneira o "arsenal" que ele desenvolvera com sua epistemologia o equipa para essas tarefas. O resultado dessa inspeção não poderia, ao menos de início, ser menos animador. A primeira descrição que nosso filósofo faz do patamar em que se encontra é a seguinte:

Considero-me como um homem que, depois de parar em muitas regiões costeiras, e mal tendo escapado de um naufrágio ao passar por uma pequena fenda, tem, ainda, temeridade suficiente para se atirar ao mar na mesma embarcação furada e abatida pelas intempéries, e até mesmo leva suas ambições longe o bastante para tentar navegar ao redor do globo sob essas circunstâncias desvantajosas ${ }^{113}$. (HUME 31, p. 172)

Esse estado resulta do fato de o autor estar abatido em função de lembranças de erros passados e de estar plenamente consciente da fraqueza das faculdades de que deve fazer uso no restante de sua empreitada, além de saber que está completamente fora de seu alcance reparar tais faculdades. Hume afirma, então, que os perigos que corre o deixam em um estado de melancolia. E já que essa paixão, mais do que as outras, tende a dar vazão a si mesma, ele não tem como se abster de alimentar seu desespero (HUME 31, p. 172). Nosso filósofo tem boas razões para estar assustado. Não se trata, aqui, apenas da possibilidade de incorrer em erros teóricos. Ele se sente assustado e confuso por perceber que está completamente sozinho. Chega a ver-se como "um monstro estranho e rude, que, não sendo capaz de se misturar e de se unir à sociedade, foi expelido de todo o comércio humano, e completamente abandonado e desconsolado ${ }^{114,}$ (HUME 31, p. 172).

É verdade que ambas as metáforas a que nos referimos aqui possuem um forte teor literário, o que torna bastante tentadora a possibilidade de vê-las como textos que possuem uma função meramente retórica. Essa solução, por mais fácil que pareça, não é

\footnotetext{
113 "Methinks I am like a man, who having struck on many shoals, and having narrowly escap'd shipwreck in passing a small frith, has yet the temerity to put out to sea in the same leaky weather-beaten vessel, and even carries his ambition so far as to think of compassing the globe under these disadvantageous circumstances”.

114 “[...] some strange uncouth monster, Who net being able to mingle and unite in society, has been expell'd all human commerce, and left utterly abandon'd and disconsolate’.
} 
de todo convincente. Ora, ainda que haja, sem a menor dúvida, algo de retórico em boa parte da Conclusão do Livro 1 do Tratado, esse momento do texto deve ser visto como pertencente a algo como uma dialética que terminará por nos revelar os primeiros lampejos daquilo que é, para Hume, a verdadeira filosofia. E neste momento dessa dialética, Hume se pergunta que confiança pode atribuir a suas empreitadas ousadas, se, além das fraquezas peculiares a ele próprio, ele possui tantas que são comuns à natureza humana. Além disso, mostra-se preocupado por não ter garantias de que, rompendo com as opiniões mais aceitas, chegou a qualquer verdade. Depois de todos os raciocínios do Livro I, nosso filósofo não tem razões para assentir a nenhuma de suas conclusões; só lhe resta uma forte propensão a aderir a esta ou àquela. “A experiência”, diz ele, “é um princípio que me instrui quanto às várias conjunções de objetos no passado. O hábito é outro princípio, que me determina a esperar o mesmo para o futuro e, conspirando ambos para operar sobre a imaginação, fazem-me formar certas ideias de maneira mais intensa e vívida do que outras ${ }^{115}$ ” (HUME 31, p. 172). E sem essa capacidade da mente de atribuir mais vivacidade a certas ideias do que a outras, não haveria como dar assentimento a qualquer objeto além daqueles imediatamente presentes aos sentidos, e mesmo estes seriam apenas parte da cadeia de percepções que denominamos nós mesmos. E mesmo entre elas, só teríamos como admitir aquelas presentes no instante atual. A conclusão, aqui, é que memória, sentidos e entendimento estão todos fundamentados na imaginação, na vivacidade das ideias.

Logo em seguida, porém, Hume dirá que esse é um princípio que não podemos seguir em todas as suas variações. Não podemos nos esquecer, afinal, de que a imaginação é o princípio que nos permite raciocinar sobre causas e efeitos, mas é, também, o princípio que nos leva a ficções como a da existência contínua, de que tratamos no Capítulo I. E como já deve ter ficado até mais que evidente, ainda que tanto o raciocínio sobre causa e efeito quanto a ideia de existência contínua sejam "naturais e necessárias na mente humana”, esses dois fatores são diretamente contrários. No fim das contas, simplesmente não é possível raciocinar a partir de causas e efeitos e, ainda assim, aceitar a existência contínua como algo que pode ser suficientemente

115 "Experience is a principle, which instructs me in the several conjunctions of objects for the past. Habit is another principle, which determines me to expect the same for the future; and both of them conspiring to operate upon the imagination, make me form certain ideas in a more intense and lively manner, than others $[\ldots] "$. 
fundamentado. De fato, pelo tom desesperado com que Hume se indaga sobre o tema, parece-lhe impossível ajustar essas duas condições ou escolher uma delas. Além disso, ele considera que pular de um princípio a outro conforme a conveniência, como fazem tantos filósofos, seria mostrar-se indigno desse “título glorioso” (o de filósofo, é claro), já que ele estaria aceitando uma contradição bastante explícita , contradição esta que seria mais perdoável se trouxesse consigo maior solidez ou maior satisfação em "outras partes de nosso raciocínio”. Definitivamente, entretanto, não é o que acontece. Pelo contrário, ao empregar o entendimento humano sobre seus próprios princípios primeiros, o que acontece é que todas as nossas crenças anteriores tornam-se ridículas (HUME 31, p. 173).

Prosseguindo, nosso autor afirma que não há nada que investiguemos com mais curiosidade que as causas de todos os fenômenos, e que sempre procuramos pelo princípio original, último, em vez de nos contentarmos com causas imediatas. Portanto, parece que não temos como nos contentar enquanto não descobrirmos a "energia” que liga a causa ao efeito, a “qualidade eficaz” que realiza essa ligação. Assim, é inevitável que nos sintamos desapontados ao aprender que essa conexão está unicamente em nós mesmos e é apenas uma determinação da mente adquirida pelo costume, a qual faz com que sintamos a transição de um objeto a seu correlato usual, ou de uma impressão para a ideia vívida de seu efeito. Essa conclusão, diz Hume, além de acabar com nossas esperanças de conhecimento, mata o próprio desejo de obtê-lo, já que, quando falamos em descobrir o princípio último enquanto algo que reside nos próprios objetos, ou nos contradizemos, ou falamos algo completamente desprovido de significado (HUME 31, p. 173).

Essa deficiência, bem como a completa ignorância em que nos encontramos com relação ao problema da causalidade, não é sentida na vida comum. Entretanto, isso se deve apenas a uma ilusão da imaginação, de modo que a questão é até que ponto devemos assentir a essas ilusões. E para Hume, essa questão é não apenas extremamente difícil como, além disso, coloca um dilema sumamente importante. Se assentirmos a tudo que a imaginação nos sugerir, certamente correremos o risco de incorrer em todo tipo de absurdos. Se, por outro lado, decidirmos aderir apenas às propriedades "gerais e mais estabelecidas” da imaginação, teremos de lidar com um outro perigo, tão preocupante quanto o primeiro, já que o entendimento, quando se volta para si mesmo, termina por se subverter e destruir não apenas as evidências com as quais lidamos em 
filosofia, mas também aquelas referentes à vida comum. Temos aí, como o próprio Hume nos informa em uma nota, referência clara à seção sobre "Do Ceticismo quanto à Razão”, em que ele mostra de que modo a razão demonstrativa, quando empregada no exame de si mesma, termina por se subverter, mostrando ser completamente indigna de confiança. De qualquer maneira, se nos salvamos desse ceticismo completo, é apenas por nossa propensão a conceber com dificuldade as coisas mais remotas, as quais somos incapazes de conceber com a facilidade que acompanha aquelas que são mais simples ou estão mais próximas. Então, pode parecer tentador proibir qualquer raciocínio minimamente difícil ou abstruso, e essa é uma possibilidade que Hume, em passagem algo dramática, chega a considerar. Entretanto, nosso filósofo não pode aceitar essa saída, já que isso impossibilitaria, sem a menor dúvida, qualquer ciência ou filosofia. “Não temos, portanto, escolha alguma, a não ser entre uma razão imperfeita e razão nenhuma ${ }^{116 ”}$ (HUME 31, p. 174). Em outras palavras, devemos escolher entre renunciar completamente a qualquer regra de raciocínio, cedendo a quaisquer devaneios da imaginação, ou aceitar uma razão que já se mostrara indigna de qualquer confiança ${ }^{117}$. E Hume confessa não saber o que fazer nessa situação, mas observa que essa é uma dificuldade a que raramente se dá muita atenção e, mesmo quando isso ocorre, ela é rapidamente esquecida, já que reflexões muito refinadas quase não têm influência sobre nós, ainda que isso não queira dizer que elas não devam ter influência.

A convicção de nosso autor sobre a incapacidade de raciocínios abstrusos de nos influenciar, é claro, não poderia durar muito. Quase não nos surpreende que ele a descarte logo em seguida, como que retornando ao estado inicial de melancolia em que

116 "We have, therefore, no choice left but betwixt a false reason and none at all”.

${ }^{117}$ Em seu A Progress of Sentiments, Annette Baier, a quem certamente devemos uma análise bastante pertinente da Conclusão do Livro 1 do Tratado, afirma que, por "razão nenhuma”, Hume quer dizer "a razão subvertida por sua própria aplicação irrestrita e reflexiva”. Nesse aspecto em particular, não podemos concordar com essa autora. No contexto em que a passagem da escolha entre razão imperfeita ou razão alguma aparece, fica claro que, por "razão alguma”, Hume quer dizer simplesmente a imaginação agindo sem ser guiada por qualquer princípio que não seja completamente espontâneo. Isso, como já vimos, certamente levaria a todo tipo de fantasias. Entretanto, parece-nos que a subversão da razão e, apesar da nota de Hume, também as contradições impostas entre as percepções “comuns” e aquilo que nos é revelado pelo raciocínio causal são motivos para que Hume fale em um recurso a "razão alguma”, não aquilo mesmo que ele entende por essa expressão. Cf. BAIER 2, p. 14. 
se encontrava no começo da seção, ao declarar que as incontáveis contradições que presenciou pesaram tanto sobre ele, e aqueceram de tal modo seu cérebro que ele está pronto a renegar qualquer tipo de crença sobre qualquer assunto. Hume não apenas declara-se confuso com questões do tipo “Onde estou, ou o que sou? De que causas derivo minha existência, e a que condição retornarei? Os favores de quem devo cortejar, e a ira de quem devo temer? Que seres me cercam? E sobre quem tenho qualquer

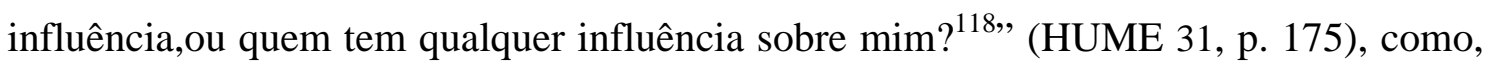
mais do que isso, considera estar na situação mais deplorável que poderia imaginar e envolto nas trevas mais inexpugnáveis ${ }^{119}$.

Nesse ponto do texto, Hume parece ter mais motivos para se desesperar do que no início, já que a razão, como qualquer leitor casual da Conclusão do Livro 1 já percebeu a essa altura, está muito longe de ser uma ferramenta minimamente apropriada

118 "Where am I, or what? From what causes do I derive my existence, and to what condition shall I return? Whose favour shall I court, and whose anger must I dread? What beings surround me? And on whom have I any influence, or who have any influence on me?”

119 Os passos dados por Hume até este ponto da Conclusão do Livro 1 do Tratado foram mapeados com grande precisão por Annette Baier, que tratou de destacar dez diferentes "passos" do "protagonista" até aqui: 1 - de pensador independente a monstro solitário e rejeitado; 2 - de pensador solitário a típico pensador falível; 3 - de pensador típico, sujeito aos hábitos distintivos da imaginação humana, a vítima típica de seus mecanismos autodestrutivos; 4 - de vítima da imaginação a aderente voluntário do "entendimento", a saber, a imaginação em seus mecanismos mais regulares e estabelecidos; 5 - de alguém que discrimina entre os mecanismos estabelecidos da imaginação (intelecto) e seus mecanismos triviais (a fantasia [fancy]) a agente e testemunha do desaparecimento da evidência, da total destruição da razão pela subversão a partir de seu interior; 6 - de cético total a alguém que está disposto a ser governado pela "propriedade trivial da fantasia [fancy]", mais especificamente, intolerância a raciocínios longos e elaborados, tais como os precedentes; 7 - de alguém que expulsa os raciocínios elaborados a alguém que rejeita a ciência, e quebra suas próprias regras, já que o caminho para a conversão de 1 a 6 foi mais longo que aquele de 1 a 5; 8 - de alguém que quebra suas próprias regras a alguémque renuncia a todas as regras, advogado do esquecimento das dificuldades; 9 - de alguém que liberta das normas e de suas dificuldades a um libertador fracassado, incapaz de esquecer que foi pelo raciocínio que chegou a banir as normas da razão; 10 - de pensador que manifestamente contradiz a si mesmo a alguém que duvida de si mesmo desesperadamente, "na condição mais deplorável que se pode imaginar”. De maneira geral, não temos por que discordar desse esquema e, tendo ele parecido útil como resumo do caminho perseguido por Hume até esse ponto da Conclusão do Livro 1, pareceu-nos interessante acrescentá-lo aqui, ainda que traduzido de maneira certamente bastante livre. Para o esquema original, ver BAIER 2, pp. 17-8. 
para salvar nosso filósofo da melancolia em que ela mesma o colocou. De fato, será a natureza que fará o papel de sétima cavalaria:

\begin{abstract}
Muito felizmente acontece que, já que a razão é incapaz de dispersar essas nuvens, a própria natureza basta para esse propósito, e me cura dessa melancolia e desse delírio filosóficos, seja relaxando essa inclinação da mente, seja por algum passatempo, ou impressão vívida dos meus sentidos, que oblitera todas essas quimeras. Eu janto, jogo uma partida de gamão, converso e me alegro com meus amigos; e quando, depois de três ou quatro horas de diversão, eu tento retornar a essas especulações, elas parecem tão frias, tão forçadas, tão ridículas, que não consigo encontrar em meu coração a vontade de adentrá-las ainda mais ${ }^{120}$.
\end{abstract} (HUME 31, p. 175)

Poderia parecer, evidentemente, que nosso filósofo pretende, agora, um retorno àquele estágio em que buscaria simplesmente aceitar completamente a vida comum, que, como já vimos, não percebe as inúmeras dificuldades em que ele se havia metido. Essa falsa impressão pode persistir quando, logo a seguir, vemos um Hume que se diz, então, “absoluta e necessariamente determinado a viver”. Mais do que isso, ele chega a afirmar que quando percebe que, apesar de suas propensões naturais o compelirem a aceitar as máximas da vida comum, ele ainda sente como que restos de sua disposição filosófica, ele pensa em atirar ao fogo todos os seus livros, e nunca mais retornar às especulações que haviam sido a causa de sua melancolia. Nesse momento, nosso autor chega a afirmar que a maior mostra de sua disposição cética consistiria justamente em submeter-se a seus sentidos e a seu entendimento de maneira cega, mas que daí não se segue, de maneira alguma, que ele deva se isolar do convívio dos outros homens para se torturar com sutilezas e sofismas, muito menos em um momento em que ele parece completamente incapaz até mesmo de se satisfazer quanto à razoabilidade de esforços que ele considera sobremaneira dolorosos e que não têm garantia alguma de poder levar

120 "Most fortunately it happens, that since reason is incapable of dispelling these clouds, nature herself suffices to that purpose, and cures me of this philosophical melancholy and delirium, either by relaxing this bent of mind, or by some avocation, and lively impression of my senses, which obliterate all these chimeras. I dine, I play a game of back-gammon, I converse, and am merry with my friends; and when after three or four hour's amusement, I wou'd return to these speculations, they appear so cold, and strain'd, and ridiculous, that I cannot find in my heart to enter into them any farther”. 
a qualquer verdade. Se nosso filósofo deve ser um tolo, como, diz ele, são todos os homens que acreditam no que quer que seja, que suas tolices possam, ao menos, ser agradáveis. Quando resistir a suas inclinações, que seja contra aquelas que o levam a filosofar, levando-o à mais inóspita solidão e às paisagens mais rudes que ele já encontrou. É só isso que se pode esperar da filosofia, que não tem absolutamente nada a opor a esses sentimentos. Mais uma vez, Hume afirma que, se podemos esperar qualquer vitória sobre eles, é apenas por meio do retorno de um bom humor. Desse modo, se pretendermos ser filósofos, isso deve ocorrer sempre com base em princípios céticos e, portanto, a partir de uma inclinação, já que a razão, ao se misturar a uma propensão, é algo a que devemos assentir.

A partir daí, começa a se desenhar a construção de um modo de filosofar que Hume parece considerar aceitável. A filosofia se dará em momentos em que, cansado das atividades sociais, estivermos envolvidos com nossos devaneios privados. Além disso, nosso autor afirma que se sente motivado mais uma vez a filosofar por sua curiosidade acerca de temas como o bem e o mal morais, os fundamentos do governo e as causas das diversas paixões que atuam sobre ele. Além disso, ele se declara inquieto por não saber o que o leva a aprovar um objeto e censurar outro, ou como julgar sobre a verdade e a falsidade, sem saber quais são os princípios que o guiam. Por fim, ele pensa em colaborar para um aumento nos conhecimentos atingidos pelo mundo letrado, que ele acredita estar em situação nada vantajosa. Mas principalmente, como já dissemos, ele filosofará porque, se não o fizer, perderá no âmbito do prazer (HUME 31, p. 176). É importante notar que, nesse ponto, começa a ser delineada a figura do verdadeiro filósofo. Como veremos posteriormente, ela passará por algumas alterações ao longo da obra de Hume, mas alguns dos aspectos mais importantes do caráter desse tipo de pensador já estão presentes aqui. Em primeiro lugar, o verdadeiro filósofo raciocina motivado por uma propensão natural. Mais do que isso, como trataremos de deixar claro mais adiante, os raciocínios que ele validar só serão capazes de se impor porque serão, em última análise, eles mesmos redutíveis a certas propensões. Além disso, o filósofo que nosso autor começa a delinear aqui não é, de maneira alguma, um pensador solitário, como aquele que empregaria uma razão cartesiana, mas alguém que compartilha com os outros homens uma experiência comum, a qual deverá ser processada por princípios da natureza humana que, no fim das contas, têm muito pouco 
a ver com aqueles que os racionalistas, de maneira geral, diriam ser os que efetivamente conduzem ao conhecimento ${ }^{121}$.

Em seguida, Hume afirma que, mesmo que suas propensões o guiem a buscar temas alheios à esfera da vida comum, isso não será um grande problema. É claro que isso pode não soar muito sensato, já que, aparentemente, ele não parece ter encontrado qualquer evidência nova para dedicar seus raciocínios a esse tipo de assunto. Ainda assim, parece inevitável que ele se sinta tentado, ocasionalmente, a empreender esse tipo de busca, já que a mente do homem não é “tão estreita quanto a dos animais”. De qualquer maneira, é preciso que escolhamos nosso guia nesse tipo de busca e, entre a filosofia e a religião, nosso autor recomenda a primeira. Isso porque, para ele, a superstição surge naturalmente das “opiniões populares da humanidade” e, assim, tende a exercer uma grande influência sobre a mente, sendo capaz de nos perturbar de maneiras que seriam simplesmente inacessíveis para a filosofia. Esta, mesmo quando nos apresenta sentimentos falsos ou extravagantes, fornece apenas especulações que nosso filósofo considera frias e gerais, o que faz com que sejam incapazes de perturbar nossas propensões naturais. Ainda que os cínicos, por exemplo, tenham fornecido uma exceção considerável, “os erros em religião são perigosos, aqueles que acontecem em filosofia, apenas ridículos ${ }^{122 » " ~(H U M E ~ 31, ~ p . ~ 177) . ~ P a r e c e ~ q u e ~ H u m e ~ c o n t r a d i z, ~ n e s s a ~}$ passagem, aquilo que defendemos no capítulo anterior. Insistimos, então que, ainda que Hume, como mostraremos mais adiante, tenha previsto já no Tratado as consequências bastante destrutivas que sua filosofia teria para a religião, e que tenha “cortado” um capítulo sobre os milagres que, até onde se sabe, seria bastante semelhante àquele que depois foi publicado na Investigação sobre o entendimento humano, tudo indica que ele ainda não pensava, em seu trabalho de estreia, a filosofia como algo que poderia ter

\footnotetext{
${ }^{121}$ Esse é um ponto bastante importante para alguns comentadores, e aparece de maneira recorrente, por exemplo, nas obras de Annette Baier e Donald Livingston. Ainda que os dois (e vários outros comentadores que fazem uma análise de Hume que o alinha principalmente a alguma forma de naturalismo) tendam a uma leitura de Hume que o torna menos cético do que a que proporemos aqui, certamente não há como negar que o caráter (entre outros aspectos) social da experiência é algo importante para Hume. O que tentaremos fazer a esse respeito será justamente propor uma interpretação mais cética da filosofia humiana do que a oferecida por esses autores e, ainda assim, salvaguardar o caráter eminentemente social da experiência.
}

122 “[...] the errors in religion are dangerous; those in philosophy only ridiculous”. 
grande impacto sobre o homem comum. Ainda que, como vimos, ele acreditasse que ela deve ser motivadas por propensões que são exatamente da mesma natureza que aquelas que movem os não-filósofos (e, como veremos posteriormente, deve, mais do que isso, ser também guiada por princípios que estão presentes igualmente em filósofos e em homens comuns), ele ainda não indicava, quando da escrita do Tratado, que eles pudessem ser de algum modo “transformados” pela filosofia ou algo do tipo, talvez por ainda não ter considerado a propensão nada desprezível que ela tem para se ligar às tais “opiniões populares”. A própria introdução dessa obra já dá pistas disso. Nela, Hume afirma que depõe contra o mundo das letras o fato de o homem comum ser capaz de intuir que algo de errado ocorre no ambiente dos, digamos, intelectuais. Vale dizer que, na Introdução, Hume se refere aos homens comuns como “a turba lá fora”, o que já é um bom indício de que não era esse tipo de pessoa que ele pretendia que o Tratado atingisse. Isso fica ainda mais claro quando atentamos para o parágrafo que encerra o Tratado da natureza humana. É aí que Hume emprega pela primeira vez em sua obra a metáfora do anatomista e do pintor, que representam, respectivamente, uma filosofia difícil, acessível apenas aos eruditos, e uma outra fácil, que serviria principalmente para exortar o homem comum à prática da virtude. Diferentemente do que vemos na Seção 1 da primeira Investigação, muito mais conhecida, Hume afirma, ao fim de seu primeiro escrito, que seria impossível conciliar esses dois caracteres (HUME 31, p. 395). Essa foi a posição expressa por ele, também, em uma carta a Francis Hutcheson em que eram discutidos certos aspectos do Tratado. Parece inegável, então, que teria ocorrido uma mudança de posição, por parte de nosso autor, com relação à possibilidade de empregar sua filosofia para atingir um público mais amplo que aquele composto pelos letrados sem abrir mão, para isso, do rigor daquilo que ele consideraria uma filosofia mais abstrusa. Trataremos desse assunto com mais detalhes posteriormente. Por ora, basta que tenhamos fundamentado a afirmação de que Hume não parecia considerar, quando escreveu o Tratado, que a filosofia fosse algo que pudesse causar grande impacto sobre parte significativa dos homens comuns.

Retornando à Conclusão do Livro 1, notamos que isso parece ser reforçado pelo fato de nosso autor acrescentar, logo após seus comentários sobre filosofia e religião, que reconhece haver na Inglaterra de seu tempo muitos cavalheiros honestos que não se preocupam com assuntos que estão muito além de seu dia-a-dia e que não pretende, de maneira alguma, torná-los filósofos, até por considerar que eles fariam bem em 
“permanecer onde estão”. O que Hume gostaria de poder fazer é, como já vimos, conferir àqueles que já são filósofos “uma porção dessa mistura terrena grosseira, que é um ingrediente que comumente lhes faz muita falta, e que serviria para temperar essas partículas incandescentes de que eles são compostos ${ }^{123}$ ” (HUME 31, p. 177). Afinal, quando praticamos a filosofia com uma imaginação demasiadamente acalorada, esposando certos princípios apenas porque parecem particularmente agradáveis, não temos como raciocinar de modo que não entre em conflito com a prática comum. Apenas a remoção desse tipo de procedimento tornaria possível a criação de uma filosofia que, se não verdadeira, poderia ser, ao menos, satisfatória e resistente aos exames mais críticos. Esse é um objetivo que Hume considera que não deveríamos abandonar apenas por não ter ainda havido sucesso nesse sentido. Ora, além das interrupções e dos vários motivos que desencorajam a atividade científica, parece-lhe que sua própria época ainda não está em condições de fornecer teorias que possam realmente sobreviver ao teste do tempo. Tudo que nosso autor espera é fornecer alguma contribuição para o avanço do conhecimento, fazendo com que os filósofos se voltem para assuntos em que algum grau de convicção pode ser atingido. Nesse sentido, a importância concedida por Hume ao estudo da natureza humana não é casual, já que esse tema, apesar de ter sido renegado por tanto tempo, é, para ele, a única "ciência do homem” possível. E a esperança de trazer esse assunto à atenção de todos é parte do que o cura da melancolia que o afligiu mais de uma vez ao longo da Conclusão do Livro 1 do Tratado. Nesse ponto, ele recomenda que o leitor apenas o siga caso esteja tomado por essa mesma disposição tranqüila. Se não for o caso, que espere o retorno da aplicação e do bom humor. É interessante observar que Hume considera a conduta de um homem que estuda filosofia desse modo despreocupado é mais verdadeiramente cética do que a de alguém que, ao sentir a disposição para os estudos, é tomado de tal forma por dúvidas e termina por rejeitar seu humor filosófico ${ }^{124}$. "Um verdadeiro

\footnotetext{
123 “[...] a share of this gross earthy mixture, as an ingredient, which they commonly stand much in need of, and which wou'd serve to temper those fiery particles, of which they are compos'd”.

124 “Despreocupada” traduz, nessa passagem a palavra "careless”. Escolhemos essa tradução porque não queríamos que o uso de qualquer outro termo sugerisse que Hume propõe uma filosofia desleixada ou que peca no que diz respeito ao rigor. Como nos lembra Annette Baier, o Oxford English Dictionary prevê o sentido de "despreocupação", citando, para confirmar essa possibilidade, uma referência bíblica ("They dwell careless after the manner of the Zidonians, quiet and secure" (Viviam despreocupados como os sidônios, tranqüilos e em segurança) - Juízes, 18.7).
} 
cético", diz Hume, "desconfiará de suas dúvidas filosóficas, bem como de sua convicção filosófica, e nunca recusará qualquer satisfação inocente que se ofereça por conta de qualquer uma delas ${ }^{125,}$ (HUME 31, p. 177).

No parágrafo que encerra a Conclusão do Livro 1 do Tratado, Hume começa a dar mostras de que seu ceticismo não será aquela forma de pirronismo contra o qual, em seu tempo, erguiam-se enormes preconceitos, ao afirmar que não apenas deveríamos, de maneira geral, ceder a nossas inclinações em assuntos filosóficos mais elaborados, como, também, dar vazão a nossas propensões de nos expressarmos de maneira categórica em certos temas, dependendo do ângulo em que os observamos em todos os instantes. Para ele, seria mais fácil impedir qualquer tipo de investigação do que evitar que nos expressássemos dessa maneira, o que acontece naturalmente quando cremos que investigamos um objeto de maneira completa e exata. Nessas situações, diz Hume, devemos deixar de lado não apenas nosso ceticismo, mas, também, nossa modéstia, e podemos esquecer qualquer escrúpulo em usar expressões como “é evidente”, “é certo”, “é inegável”. Se é preciso que Hume faça essa afirmação, é justamente porque o fato de ele ter empregado expressões desse tipo poderia ser usado como objeção contra a doutrina proposta por ele, já que seus adversários poderiam acusá-lo de dogmatismo. Ele faz questão, portanto, de afirmar que o uso dessas expressões não é, de modo algum, indicativo de dogmatismo ou de presunção, sentimentos que ele considera que não seriam apropriados para ninguém, principalmente, para um cético (HUME 31, p. 178).

Até aqui, buscamos seguir bem de perto o próprio texto da Conclusão do Livro 1 do Tratado. Podemos fazer, agora, algumas considerações sobre o que ela nos permite dizer acerca do modo como Hume vê a própria filosofia. Em primeiro lugar, essa seção parece confirmar o que já havíamos dito, nos capítulos anteriores, sobre a necessidade de que o filósofo não se distancie demasiadamente do que poderíamos denominar a experiência tal como ela aparece na vida comum. E como veremos ainda neste capítulo, isso poderá permitir que a filosofia ultrapasse, em alguns aspectos, as opiniões do homem comum, mas o ponto de partida do filósofo ainda será a experiência que ele compartilha com o homem comum. Como também veremos adiante, isso quer dizer que o mundo percebido pelo vulgo, ainda que seja uma série de ficções, deverá, em certa

\footnotetext{
125 " [...] Will be diffident of his philosophical doubts, as well as of his philosophical conviction; and will never refuse any innocent satisfaction, which offers itself, upon account of either of them”.
} 
medida, ser aceito pelo filósofo, ainda que este procure constantemente explicar os princípios da natureza humana responsáveis pelas ficções em questão. Na verdade, boa parte do trabalho daqueles que se dedicam ao que Hume considera a verdadeira filosofia consistirá precisamente em distinguir, entre as várias ficções que interferem nas vidas dos homens, aquelas que merecem nosso assentimento daquelas que são simplesmente injustificáveis, e isso será possível exatamente por um exame cuidadoso dos fatores que geram em nós as tais propensões que Hume afirma serem o único motivo que o leva a crer em certas coisas em detrimento de outras.

Existe, além disso, um outro aspecto importante nessa filosofia que pretende misturar a si mesma parte da "mistura terrena grosseira" que abunda nas pessoas comuns: ela não deverá ser feita por um homem imbuído de uma razão que deve ser vista como, por assim dizer, uma centelha divina que funciona melhor quando isolada deste mundo que percebemos. O verdadeiro filósofo, ainda que possa escrever sozinho em seu gabinete, é, para nosso autor, um ser essencialmente social. Como vimos, sentese inseguro quando suas opiniões correm um grande risco de não serem aprovadas. $\mathrm{O}$ isolamento faz com que um ceticismo excessivo se apodere dele, levando-o a ver em si mesmo um monstro estranho e rude, rejeitado não apenas pelas pessoas comuns, mas também por todos os metafísicos cujos sistemas foram por ele atacados. É importante notar que esse isolamento parece ser efeito bastante característico de uma filosofia que, ao voltar-se para si mesma e para os princípios que a conduzem, leva a um ceticismo bastante extremado. Quanto aos cínicos, ainda que não recebam tratamento tão cuidadoso no Tratado quanto aquele que lhes é conferido (ainda que não com exclusividade) no Diálogo que encerra a segunda Investigação, parecem ser acometidos por uma forma de entusiasmo, e não à melancolia cética de que Hume teria sido vítima. O que o "estado deplorável” em que nosso autor se encontra sinaliza é, assim, não uma situação “melhor” por parte dos cínicos em relação ao cético melancólico e delirante, mas o fato de ele ter uma doença diferente. É como se a situação horrível em que nosso autor se encontra ao chegar ao ceticismo extremo fosse, do ponto de vista meramente teórico, mais sustentável que a filosofia cínica, que incorre não apenas no pecado de sucumbir ao emprego de "princípios favoritos", mas, também, o de buscar, mesmo na vida prática, dobrar a realidade a seus próprios cânones. De certa maneira, então, o cínico (ou, para todos os efeitos, alguém como Pascal) está em situação muito mais complicada que a de qualquer hobbesiano, já que não se limita a “atribuir novas causas” 
a fenômenos já existentes, mas pretende mesmo colocar o filósofo em algo como um universo paralelo. Ainda que Hume não realize esse tipo de comparação nesse ponto do Tratado, é apropriado, agora que lidamos diretamente com um texto em que, ao tratar da própria filosofia, nosso autor a coloca diretamente no terreno da vida comum, elucidarmos, em termos bastante próximos daqueles empregados por ele, mais alguns aspectos de temas sobre os quais já havíamos dito algo. Além disso, essas considerações podem servir para mostrar que, como o próprio Hume já havia admitido em um ponto anterior da Conclusão do Livro 1, princípios filosóficos podem, no fim das contas, interferir no estado de espírito daqueles que os aceitam. Se o caso dos cínicos aparece como uma exceção, isso se explica pelo fato de Hume não considerar, na seção de que estamos tratando agora, que a filosofia poderia ter um grande impacto não na vida de seus praticantes, mas do homem comum. Quanto ao próprio filósofo, deve sempre ser bastante cuidadoso para não se afastar do mundo percebido, sob pena de se tornar ou alguém como o cínico ou alguém que será levado ao desespero por ver a si mesmo como alguém prestes a naufragar ou como um monstro estranho e rude que não tem lugar neste mundo.

Entretanto, não é apenas por cortejar a aprovação de seus semelhantes que o verdadeiro filósofo deve ser visto como um pensador ligado à vida em sociedade. É importante lembrarmos que a natureza que o salva do estado melancólico que lhe havia sido imposto pelo ceticismo excessivo vem, em primeiro lugar, na forma de um jantar com os amigos ou de um jogo de gamão. Essa metáfora não indica apenas que, ao se cansar de seus estudos, aquele que se dedica à filosofia precisa de um período de descanso. A participação na vida social é importante, como já deve estar claro a esta altura, para que o filósofo nunca peca de vista as propensões naturais que motivam sua atividade e que, como veremos, servirão para determinar o próprio modo como ele a exercerá. Mas isso, evidentemente, não pode ocorrer com um pensador que se limita a observar a distância criaturas que ele conceberá como meros objetos de estudo. A verdadeira filosofia advém, para Hume, de um pensador que participa efetivamente da mesma vida que aquela levada pelos não-filósofos. Podemos dizer, então, que, ainda que, à época da escrita do Tratado, nosso autor ainda não estivesse preocupado em afirmar que o "mundo da conversação" (como ele o chama em "Of Essay Writing) seria beneficiado por sua concepção de filosofia, é certo que já se havia dado conta dos benefícios que o "mundo letrado" poderia extrair de pensadores que não se 
enclausurassem em seus gabinetes. De certa maneira, a clausura no gabinete representa, para Hume, o ato do filósofo que parte de uma razão concebida como infalível e capaz de descobrir tudo que se pode descobrir por um exercício que não depende em nada da própria participação do filósofo no mundo ${ }^{126}$. Assim, a própria teoria do conhecimento desenvolvida por Hume pode ser vista uma refutação dessa razão que, como o cético pode mostrar por experimentos bastante acessíveis, subverte-se a si mesma quando se volta para si própria. Desse modo, parece-nos que a defesa da tese segundo a qual a filosofia deve se aproximar do senso comum é resultado direto de um estudo dos aspectos da natureza humana simplesmente porque, no fim das contas, o que Hume fará é justamente reavaliar quais são os princípios da mente capazes de fazer com que conheçamos o que quer que seja. E a filosofia que resultará dessa maneira de se considerar as faculdades do homem pode até se pautar por uma "razão imperfeita”, mas certamente será satisfatória, já que poderá resultar em conclusões que, ainda que possam ser falíveis e não resistir ao crivo da posteridade, certamente terão, por assim dizer, uma sensatez que não poderíamos esperar de uma forma de raciocínio que, além de não ser confiável por conta de sua tendência a subverter-se, quase não se reconhece como parte do mundo que deseja desvendar. O verdadeiro filósofo, então, reconhece-se como um ser limitado que não poderá ir além do que lhe permitirem os pontos de partida que a experiência comum oferece, mas pelo menos estará consciente de ter sido guiado por princípios que são os mais apropriados para que ele saiba não tudo que há para saber, mas tudo que é possível saber, ainda que, é claro, a palavra saber não tenha, para ele, o mesmo sentido absoluto e, portanto, definitivo que ela tem para os adeptos da falsa filosofia.

\footnotetext{
${ }^{126}$ Não seria impróprio dizermos que essa concepção de razão implica na consideração de que ela tem algo de divino. Se pensarmos que, entre os principais alvos de Hume, estão os cartesianos, os hobbesianos e os newtonianos que viam nas relações entre as coisas (dedutíveis de maneira puramente matemática) objetos de investigação que poderiam explicar até mesmo a moral nos mesmos termos em que se resolvem equações, não é difícil reconhecer, na teoria do conhecimento humiana, não apenas consequências destrutivas a certas conclusões teológicas, mas, também, a uma concepção de razão que não seria possível se ela não fosse reconhecida como tendo traços bastante perceptíveis da própria razão divina. Isso fica particularmente óbvio no caso de Descartes, que concebe a si mesmo, antes de qualquer outra coisa, como uma res cogitans que chega a conhecer Deus partindo, antes de qualquer outra coisa, do princípio de que é evidente que, havendo mais ser na causa que no efeito (e não nos esqueçamos de que o efeito é, até aqui, única e exclusivamente algo que pensa), Deus deve necessariamente existir, o que implica que a coisa pensante deve ser uma versão menos perfeita da própria inteligência divina.
} 


\section{Conhecimento, experiência e natureza}

Outro aspecto da filosofia que Hume apresenta na Conclusão do Livro 1 do Tratado é que ela é, como diz o autor com todas as letras, uma filosofia cética. Isso não quer dizer que ele pretende defender uma forma extrema de ceticismo. As consequências desse tipo de postura filosófica seriam, como já vimos, uma melancolia que simplesmente seria incompatível com o prosseguimento de qualquer raciocínio e também seria enormemente prejudicial mesmo à vida comum. Além disso, parece que o ceticismo de nosso filósofo se dá como consequência de uma investigação dos princípios da natureza humana que são responsáveis pelo conhecimento. Parece, então, que alguma forma de ceticismo e alguma forma de naturalismo estão presentes na filosofia de Hume e, mais ainda, parece que esses dois aspectos são indissociáveis um do outro. Lidamos, aqui, com um problema que vem atormentando comentadores da obra do filósofo escocês há várias décadas. Se por um lado as leituras que viam em Hume um autor preocupado em demolir qualquer tipo de conhecimento foram predominantes por quase dois séculos, aquelas que tentam fazer dele um naturalista tornaram-se cada vez mais populares da década de 1940 para cá ${ }^{127}$. Mais recentemente, temos visto muitos intérpretes da filosofia humiana defenderem que ele teria sido não apenas um naturalista, mas, de fato, um realista causal, ou seja, que ele teria afirmado que as relações de causa e efeito tais como as percebemos são representativas de uma relação realmente existentes no mundo exterior, ainda que, desse próprio mundo exterior, não possamos dizer nada ${ }^{128}$. Isso não quer dizer que não haja, também, intérpretes recentes que atribuem a Hume um inegável ceticismo, seja no caso das relações de causa e efeito, seja no da existência do mundo exterior ${ }^{129}$. Mais

\footnotetext{
${ }^{127}$ Evidentemente, isso ocorreu depois dos escritos de Norman Kemp Smith sobre a obra de Hume. Na verdade, não seria exagero afirmar que mesmo os comentadores que não simpatizam de todo com o fato de ele atribuir um forte naturalismo à filosofia humiana têm para com ele algum tipo de dívida.

${ }^{128}$ Entre eles, podemos destacar Galen Strawson, John P. Wright, Barry Stroud, entre outros. De maneira geral, além de embasarem suas leituras em passagens nas quais Hume usa exaustivamente expressões como “objetos externos”, “a máquina toda” e outras desse tipo, eles reciclam, de modo às vezes um tanto exagerado, a interpretação de Kemp Smith o papel desempenhado pelas crenças naturais [natural beliefs] na teoria do conhecimento humiana.

129 Entre eles estão Robert Fogelin, Kenneth Winkler, David Fate Norton, Peter Millican e Plínio Junqueira Smith.
} 
recentemente, o debate entre essas duas interpretações vem sendo chamado New Hume Debate. O "novo" Hume seria, nesse contexto, o defensor de alguma forma de realismo causal $^{130}$. O "velho" seria aquele vinculado à "leitura padrão" [standard reading], que atribui ao filósofo escocês alguma forma de ceticismo. Comumente, aliás, os defensores do "novo Hume” tendem a atribuir à standard reading muito mais ceticismo do que os próprios defensores dela admitiriam.

Esse é um debate bem consolidado, e parece que há já algum tempo nenhum dos lados apresenta argumentos realmente novos, ainda que não tenha havido recuo por parte de nenhum dos adversários. Por esse motivo, poderia parecer completamente desnecessário inserirmos, neste ponto do presente trabalho, um tratamento de questões que nos levarão diretamente a um problema que parece simplesmente insolúvel. Bem, o caso é que uma investigação do modo como Hume lida com questões como a causalidade e a existência do mundo exterior certamente é essencial para que possamos compreender a concepção de filosofia de nosso autor, bem como uma consequência dela que consideramos de suma importância, a saber, a relação bastante estreita, no interior do pensamento humiano, entre filosofia e senso comum. Ao longo dessa investigação, empregaremos trechos, principalmente, do Livro 1 do Tratado da natureza humana e de seções convenientes da Investigação sobre o entendimento humano. Estamos cientes de que ocorreram modificações teóricas importantes de um escrito para o outro e, sempre que isso se mostrar relevante, indicaremos as mudanças e quaisquer implicações que elas possam ter. De qualquer modo, adiantamos que, seguindo a recomendação do próprio Hume, tenderemos a dar preferência ao texto da primeira Investigação sempre que surgir algum aspecto em que ele contradisser o que havia sido antes dito no Tratado. Isso porque acreditamos que nosso autor não pediu que não lêssemos seu trabalho de estreia apenas por conta de sua repercussão desfavorável (ou, digamos, falta de repercussão). Hume certamente tinha consciência de que os princípios expostos na primeira Investigação, que além de tudo tinha capítulos bastante contundentes sobre milagres e sobre a providência, poderiam ser considerados tão ofensivos quanto aqueles que haviam sido expostos no Livro 1 do Tratado. Isso indica que haveria motivos

\footnotetext{
${ }^{130}$ Essa caracterização do debate se deve a um artigo intitulado “The New Hume”, publicado por Kenneth Winkler em 1991. É importante observar que Winkler não é, de maneira alguma, um defensor do "novo Hume", apenas deu esse nome ao filósofo "resultante" das interpretações que defendem que nosso autor teria sido um realista causal.
} 
teóricos importantes pelos quais o filósofo escocês teria feito certas revisões em sua teoria do conhecimento, não seria possível reduzir o pedido de Hume a mera questão de marketing.

Feitas essas considerações, passamos, agora, a uma análise da teoria do conhecimento humiana que, longe de ter qualquer pretensão de encerrar qualquer debate entre partidários do "velho" e do "novo Hume", tem por objetivo maior embasar o que temos dito sobre a concepção humiana da verdadeira filosofia como algo que se aproxima dos raciocínios do homem comum, nos moldes que propusemos no momento anterior deste capítulo.

É bastante conhecido o modo como nosso filósofo dá início à sua teoria do conhecimento. Ele trata de distinguir nossas percepções em impressões e ideias. A diferença entre esses dois tipos de percepção estaria, para ele, apenas do grau de força e de vivacidade com que elas ocorrem. As percepções mais fortes, mais vívidas, recebem o nome de impressões. As ideias, por sua vez, seriam as percepções mais fracas, que Hume considera "as pálidas imagens delas [as impressões] no pensamento e no raciocínio $^{131 ”}$ (HUME 31, p. 7). As impressões de que as ideias são apenas cópias são todos os objetos que percebemos pelos sentidos, bem como nossas paixões e emoções. Desse modo, quando sentimos, por exemplo, o cheiro do café ou o sabor de uma maçã, somos acometidos por uma impressão. Quando nos lembramos dessas características posteriormente, temos uma ideia.

Como sabemos, Hume atribui a impressões e ideias uma semelhança exata, a não ser no que diz respeito à força e à vivacidade. Nesse ponto, temos que tratar de uma diferença entre o Tratado e a primeira Investigação. No escrito de juventude, essa cópia exata se dá apenas entre impressões e ideias simples, entendidas como percepções que

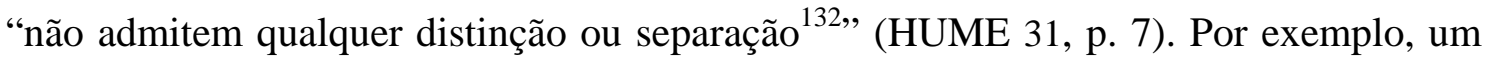
saber, um aroma e outras qualidades podem estar unidas na percepção de uma maçã, mas é fácil perceber que cada uma dessas características é diferente das outras, e pode ser concebida separadamente delas. Na Investigação, ao tratar da origem das ideias, Hume menciona ideias simples uma ou duas vezes, como no momento em que trata dos

\footnotetext{
131 “[...] the faint images of these in thinking and reasoning”.

132 “[...] admit of no distinction nor separation”.
} 
diferentes tons de azul, com o intuito de mostrar que, ao perceber uma impressão simples faltando em uma escala que segue uma determinada gradação, podemos ter uma ideia simples sem ter tido a impressão de que ela seria cópia. De qualquer maneira, o conceito de ideia simples não parece exercer nenhum papel mais relevante no restante da Investigação e tratar de maneira exaustiva dessa diferença nos parece desnecessário para os propósitos que temos aqui, de modo que nos limitaremos a apontar essa diferença entre os dois textos ${ }^{133}$. Para todos os efeitos, por mais que pareça sensato admitir que seria complicado aceitar que qualquer ideia complexa pode ser uma cópia exata da impressão que a originou, é suficiente aceitar, para os propósitos que temos aqui, uma semelhança considerável entre impressões e ideias de qualquer tipo. Não acreditamos que isso constituirá um problema, ainda mais quando nosso autor parece ter considerado que seria possível reescrever sua teoria do conhecimento sem conferir grande peso a essa questão.

No que diz respeito a essa distinção entre impressões e ideias, temos apenas mais uma consideração a fazer, a qual pode se mostrar relevante mais tarde. Devemos atentar ao fato de que Hume oferece como evidência para sua teoria experimentos que consistem em observações de exemplos extraídos da experiência comum. No Tratado, o autor declara que existe uma impressão que corresponde a cada uma das ideias simples que ele tem. Por outro lado, alguém com uma deficiência em uma de suas faculdades é incapaz de conceber uma ideia relativa a impressões que a deficiência o impede de ter (um surdo, por exemplo, seria incapaz de ter a ideia do som de uma trombeta). Na Investigação, Hume afirma que um negro ou um lapão não teriam como ter ideia do gosto do vinho e, em uma mostra clara de como nosso autor procurou se tornar mais

\footnotetext{
${ }^{133}$ Em um ensaio intitulado "Why Hume Asked Us Not to Read the Treatise”, Annette Baier sugere que, no Tratado, a noção de impressões e ideias simples era importante para a discussão empreendida por Hume sobre a divisibilidade do espaço e do tempo. A autora nota que esses conceitos são discutidos apenas de passagem na Investigação, fato que ela atribui às pretensões do autor de tratar deles com mais detalhes em uma dissertação sobre os princípios metafísicos da geometria, que acabou sendo destruída depois que Hume desistiu de publicá-la por conta das críticas de Lorde Stanhope. De qualquer maneira, como Baier também observa, a distinção entre percepções simples e complexas ainda não exerce funções de grande importância na Investigação e, honestamente, parece-nos não ter grande impacto nos dois principais problemas que desejamos analisar para avaliar a relação entre ceticismo e naturalismo na obra de Hume, a saber, a causalidade e o mundo exterior.
} 
incisivo contra a religião, a própria ideia de Deus já é mostrada como um aumento de ideias bastante cotidianas, como benevolência e sabedoria ${ }^{134}$.

Outra distinção que Hume estabelece no Tratado, mas que desaparece na Investigação, é aquela entre as impressões de sensação e as de reflexão. As primeiras seriam aquelas que surgem "na alma originalmente, e de causas desconhecidas ${ }^{135,}$ (HUME 31, p. 11). Quanto às de reflexão, elas são derivadas, em grande medida, de nossas ideias, e ocorrem da seguinte maneira: uma impressão atinge nossos sentidos, fazendo com que sintamos algum tipo de prazer ou de dor, como frio, calor, sede, fome. Quando tivermos a ideia dessa dor ou desse prazer, serão produzidas novas impressões, como desejo, aversão, medo e esperança, que são chamadas impressões de reflexão porque advêm dela. Este segundo tipo de impressão, é claro, também origina novas ideias, que talvez possam dar origem a mais impressões e ideias, e assim ad infinitum. Ora, parece evidente que o motivo pelo qual Hume não se preocupa com esse segundo tipo de impressão ao tratar da origem das ideias na primeira Investigação, é porque essa distinção é de sua importância, no Tratado, para o tratamento das paixões que ocorre ao longo de todo o Livro 2, já que as paixões são todas, para Hume, impressões de reflexão. Assim, parece-nos que essa distinção é como que posta de lado na primeira Investigação simplesmente porque não teria propósito a cumprir em um livro que trata exclusivamente de tópicos relativos à teoria do conhecimento.

Hume afirma que nossa imaginação, por mais livre que pareça ao compor suas fantasias, pode apenas combinar quaisquer ideias que estejam disponíveis a ela. Uma montanha de ouro, por exemplo, só pode ser imaginada quando temos a ideia de montanha e a ideia de ouro. Ainda assim, mesmo a combinação de ideias seria suficientemente caótica se acontecesse o tempo todo de maneira aleatória. Parece haver

\footnotetext{
${ }^{134}$ Isso é interessante porque, já no início de sua teoria do conhecimento revisada, Hume afirma que não temos como ter a impressão de Deus e, portanto, o fato de concebermos um conjunto de ideias a que damos esse nome não é, de modo algum, prova de sua existência. É claro que temos aí uma crítica bastante contundente à filosofia cartesiana (e veremos que o próprio entendimento humiano é, também, uma ruptura com uma concepção de razão que certamente se tornou preponderante com o cartesianismo), mas veremos que, além disso, esse já é um indício de onde levarão as considerações de Hume no que diz respeito à relação apropriada entre filosofia e religião.

135 “[...] in the soul originally, from unknown causes”.
} 
princípios pelos quais certas ideias naturalmente introduzem certas outras, e Hume assinala três deles: semelhança, contiguidade e causa e efeito. Essas três qualidades produzem associações mais frequentes entre as ideias e atuam como se fossem "forças delicadas que comumente prevalecem”. Isso não quer dizer que não seja possível combinar ideias de maneiras diferentes daquelas ditadas por essas relações. Estas apenas se dão de maneira mais fixa e têm esse estatuto comparável ao de uma força; de certa maneira, elas se impõem, o que não acontece, por exemplo no caso da ideia de uma montanha de ouro.

Parece importante, então, que tratemos de explicar esses princípios de conexão. A de semelhança é bastante simples de compreender: um objeto qualquer nos remete a outro semelhante. Desse modo, o retrato de um amigo, por exemplo, traz-nos a ideia do próprio amigo. A relação de contiguidade se dá porque os sentidos oferecem constantemente mudanças em que os objetos são seguidos por outros contíguos a eles, e é natural que a imaginação, influenciada pelo hábito, siga esse padrão. Quanto à relação de causa e efeito, ela é imediatamente apresentada como aquela que produz uma conexão mais forte na imaginação e, portanto, mais prontamente faz com que uma ideia remeta a outra. Além disso, ela é mais extensa, pois pode dizer respeito tanto àquilo que é causa de movimento em um objeto quanto àquilo que é causa da existência dele.

Esses não são, porém, os únicos aspectos que conferem à relação de causa e efeito seu caráter de extrema importância. Ela é a única que permite que alcancemos além daquilo que está presente imediatamente aos sentidos ou à memória (HUME 31, pp. 52-3) e, mais do que isso, ela é a relação em que todos os nossos raciocínios sobre aquilo que comumente chamamos o mundo exterior estão embasados ${ }^{136}$. Assim, é

${ }^{136}$ No Tratado, Hume trabalha com as noções de sete tipos de relações filosóficas: semelhança, identidade, relações de tempo e de espaço, proporção em quantidade ou em número, graus em uma qualidade qualquer, contrariedade e causalidade. As únicas que interessam para o conhecimento do mundo percebido são as de identidade, tempo e espaço e causalidade. Essa nomenclatura desaparece na primeira Investigação, em que Hume faz referência, simplesmente, a dois campos de conhecimento: as relações de ideias, em que qualquer proposição pode ter sua veracidade confirmada por intuição ou por demonstração (como no caso da matemática e da geometria), e questões de fato, que são basicamente aquelas relativas ao mundo percebido. Nos dois textos, a causalidade é a única relação que permite que façamos qualquer tipo de inferência para além do momento presente e, se levarmos em conta que Hume não considera a identidade (sempre pressuposta nos objetos) e as relações no tempo e no espaço como raciocínios, parece óbvio que mesmo no Tratado a relação de causa e efeito é a única pela qual podemos 
essencial, se pretendermos explicar o que é aquilo que denominamos o conhecimento das questões de fato, dissecar a relação de causa e efeito e observar cuidadosamente o seu conhecimento. E ainda mais importante, trata-se, também, de explicar o que fundamenta as inferências realizadas por causa e efeito. E tanto no Tratado quanto na primeira Investigação, a razão demonstrativa certamente não basta para explicar por que deveríamos assentir a elas. A relação de causa e efeito só pode ser explicada por motivos de outra natureza:

Já que não é do conhecimento ou de qualquer raciocínio científico que derivamos a opinião da necessidade de uma causa para cada produção nova, essa opinião deve surgir necessariamente da observação e da experiência. A próxima questão, portanto, deve naturalmente ser como a experiência dá origem a tal princípio? Mas considero que será mais fácil inserir essa questão na seguinte: por que concluímos que tais causas particulares devem necessariamente ter tais efeitos particulares, e por que formamos uma inferência das primeiras para estes últimos ${ }^{137}$ ? (HUME 31, p. 58)

É importante observarmos que, na passagem acima, “conhecimento” e “raciocínio científico” são sinônimos para razão demonstrativa. Para Hume, como se sabe, apenas as relações de ideias (ou, no vocabulário do Tratado, aquelas relações filosóficas dependentes apenas das relações que ocorrem entre ideias) são passíveis de descoberta por essa forma de razão. O que Hume faz, nessa passagem, é precisamente recusar essa forma de racionalidade como apropriada para qualquer descoberta que diga respeito à relação de causa e efeito. Isso pode ser confirmado também na seguinte passagem da Seção 4 da primeira Investigação, em que o termo “experiência” é usado

esperar conhecer algo do mundo além daquilo que se apresenta imediatamente aos nossos sentidos. Daqui para frente, por questão de conveniência, empregaremos sempre, a não ser que haja algum momento em que isso se mostre particularmente desvantajoso, a terminologia da primeira Investigação, ou seja, a que faz referência a relações de ideias e a questões de fato.

137 "Since it is not from knowledge or any scientific reasoning, that we derive the opinion of the necessity of a cause to every new production, that opinion must necessarily arise from observation and experience. The next question, then, shou'd naturally be, How experience gives rise to such a principle? But as I find it will be more convenient to sink this question in the following, Why we conclude, that such particular causes must necessarily have such particular effects, and why we form an inference from one to another?” 
de maneira claramente oposta à formulação “a priori”, que, como sabemos, está intimamente vinculada ao raciocínio demonstrativo e, é claro, a uma concepção de razão de herança cartesiana:

Aventurar-me-ei a afirmar, como uma proposição geral que não admite nenhuma exceção, que o conhecimento dessa relação [a de causa e efeito] não é, em qualquer exemplo, atingida por raciocínios $a$ priori, mas surge inteiramente da experiência, quando descobrimos que quaisquer objetos particulares estão constantemente conjugados com quaisquer outros ${ }^{138}$. (HUME 32, p. 109)

Comparando esta última passagem com a citação que vemos logo acima, fica bastante claro que Hume, nesse aspecto, não mudou em nada a sua teoria do conhecimento do Tratado para a primeira Investigação. Em ambos os casos, o que vemos é uma recusa da razão em sentido, digamos, tradicional para explicar nossos raciocínios sobre o mundo percebido. Mais do que isso, "experiência”, como acontece várias vezes no escrito de juventude, aparece, também no texto da Investigação, como algo oposto à razão que permite inferências a priori e, portanto, àquilo que havia sido definido, na passagem do Tratado que citamos há pouco, como “conhecimento” ou “raciocínios científicos”. É claro que, ocasionalmente, nosso filósofo imprime a termos como esses significados mais amplos, fazendo com que englobem tanto a matemática e a geometria quanto nossos raciocínios causais, mas, nesse momento da tese que ele desenvolve, é importante mostrar que as ferramentas de que dispomos para conhecer o mundo tal como este se nos apresenta são de natureza distinta daquela que tradicionalmente era concebida como a mais apropriada para chegarmos à verdade. Isso é algo que Hume afirma explicitamente, por exemplo, no segundo parágrafo da Seção 4 da primeira Investigação (HUME 32, p. 108) e que é confirmado por um oferecido na Seção 5, segundo o qual alguém que surgisse com todas as suas faculdade plenamente desenvolvidas, mas sem experiência alguma, não seria capaz de inferir efeitos a partir de causas, o que essa pessoa certamente seria capaz de fazer se a razão, em seu sentido mais estrito, fosse o princípio responsável pelas inferências causais (HUME 32, pp.

\footnotetext{
138 "I shall venture to affirm, as a general proposition, which admits of no exception, that the knowledge of this relation is not, in any instance, attained by reasonings a priori; but arises entirely from experience, when we find, that any particular objects are constantly conjoined with each other”.
} 
120-1). Devemos, então, verificar qual é o princípio segundo o qual somos capazes de passar com tanta naturalidade da causa a seu efeito.

No Tratado, a investigação que levará a esse princípio começa com a afirmação de que a causa deve ser contígua ao efeito no que diz respeito ao espaço e deve precedêlo no tempo ${ }^{139}$. Logo em seguida, Hume afirma que isso não é suficiente, já que um objeto pode ser contíguo e antecedente em relação a outro sem ser causa dele. Parece haver, então, uma “conexão necessária” envolvida, alguma característica da causa que a torne capaz de "produzir" seu efeito (HUME 31, p. 55). Entretanto, como sabem tanto os leitores mais casuais da obra de nosso filósofo quanto aqueles que se envolvem dos modos mais incisivos na querela entre os defensores do "novo Hume" e os da standard view, será impossível que tenhamos qualquer ideia dessa conexão ${ }^{140}$. Na verdade, tudo a que temos acesso é a conjunção constante de causa e efeito. Sem esse fator, contiguidade no espaço e sucessão temporal não bastam de maneira alguma para estabelecer a relação causal. E essa conjunção constante será a única responsável por “ativar” os princípios da natureza humana que terminarão por fazer com que estabeleçamos, em nossas mentes, a relação causal. De maneira geral, podemos dizer que a coisa se dá da seguinte maneira: após observarmos frequentemente que certo par de objetos se apresenta coligado, somos levados a esperar, quando presenciamos o primeiro, a ocorrência do segundo. Uma impressão (ou, para todos os efeitos no que diz respeito à teoria humiana da causalidade, também uma ideia presente à memória), apenas por si só, não é capaz de levar a conclusão alguma. Apenas depois de observar vários casos de conjunção constante é que somos levados a estabelecer a relação. É natural, portanto, que a repetição nos faça conceber de maneira mais vívida a ideia de

\footnotetext{
${ }^{139}$ Como assinala Annette Baier em "Why Hume Asked Us Not To Read The Treatise”, ensaio a que já fizemos referência, a necessidade de que causa e efeito sejam contíguos no espaço desaparece na primeira Investigação. Segundo Baier, isso é preciso para que Hume possa aceitar causas mentais. Não discutiremos aqui esse tema, que nos distanciaria consideravelmente de nosso propósito original e não contribuiria significativamente para o tema que nos propusemos (a concepção de filosofia de Hume, com vistas à qual empreendemos esta breve discussão da teoria do conhecimento humiana), mas julgamos que seria interessante, de qualquer modo, assinalar essa diferença entre os dois textos.

${ }^{140}$ Isso não impede, é claro, que os defensores do “novo Hume” defendam que Hume afirma a existência dessa conexão, ainda que considere que não temos como determiná-la de maneira precisa. Trataremos de explicar, em breve, por que não consideramos essa leitura apropriada.
} 
algo que comumente aparece em conjunção com algo de que temos uma impressão presente. Após sentirmos diversas vezes o calor do fogo, é natural que a ideia do calor se apresente de maneira vivaz quando estivermos na presença dele. Mais do que isso, teremos certa propensão a pensar no calor mesmo quando simplesmente pensarmos no fogo de maneira casual.

Além disso, Hume observa que a crença que decorre de uma impressão presente surge de maneira imediata. Não se faz necessária qualquer operação adicional da razão ou da imaginação, ou estaríamos conscientes desse fato. Portanto, é apenas o hábito engendrado pela repetição passada que faz com que a crença causal se estabeleça. Essa tese, talvez a mais célebre de todas as defendidas por Hume, é desenvolvida entre as seções 6 e 8 da Parte 3 do Tratado e retomada, como se sabe, na Seção 5 da primeira Investigação. Em ambos os escritos, o "elemento ausente” da relação causal é concebido com maior vivacidade do que se fosse uma ideia qualquer, trazida à mente sem que pudéssemos nos reportar a qualquer impressão ou a qualquer ideia da memória $^{141}$. E é exatamente nessa maior vivacidade que consiste a crença que depositamos na ideia que se segue à impressão presente. Em suma, portanto, a base de nossos raciocínios causais (e, portanto, de nossos raciocínios baseados na experiência) é uma crença engendrada pelo hábito, um princípio que, a partir da repetição de um grande número de casos, faz com que sejamos acometidos por certa expectativa, quando confrontados com certa impressão ou ideia da memória, de encontrarmos, logo em seguida, a ideia que lhe é correlata.

Como vimos, então, o hábito e a crença engendrada por ele fundamentam nossas inferências por causa e efeito. Isso pode fazer parecer que, de algum modo, a crença causal e aquilo que Hume havia chamado a relação de causa e efeito são a mesma coisa $^{142}$. Infelizmente, a questão não é tão simples. É verdade que, como acabamos de afirmar, a crença fornece, por assim dizer, o fundamento da relação de causa e efeito. Entretanto, acreditamos que isso vale apenas no caso do Tratado, no qual é impossível

\footnotetext{
${ }^{141}$ Falamos em "elemento ausente" e não em "efeito" porque a ideia a que passamos por conta da impressão presente pode ser também a da causa. Ora, é evidente que podemos raciocinar, também, do efeito para a causa. Do contrário, seria impossível, por exemplo, ouvirmos uma voz na sala ao lado e passar daí à conclusão de que lá está outra pessoa.

142 Essa é a posição de comentadores como Passmore, Ayer e Flew.
} 
distinguir a formação da crença pelo hábito da própria instituição da relação causal. Tanto no Livro 1 do Tratado quanto na Seção 5 da primeira Investigação, ela é apresentada unicamente como resultado do hábito e da conjunção constante, que determinam a imaginação e fazem com que sejamos acometidos por certa expectativa. Isso parece mais evidente no texto da primeira Investigação, em que, diferentemente do que acontece no Tratado, bastante confuso a esse respeito, Hume não aplica à crença causal o nome de conexão ou de associação. Vejamos, então, de que modo podemos esclarecer a relação entre a crença e a associação por causa e efeito. Começaremos pela Seção 5 da primeira Investigação.

Nesse texto, como acabamos de dizer, Hume parece se expressar de maneira bem menos confusa do que aquela que observamos no Tratado. A crença causal, apresentada como resultante do hábito, não é chamada nenhuma vez de mecanismo de associação $^{143}$, o que, se houvesse ocorrido, poderia fazer com que a confundíssemos com os três mecanismos apresentados na Seção 3. E nosso filósofo afirma, já na Seção 5, haver uma analogia entre a vivificação das ideias resultante da crença causal e aquela que víamos no caso dos mecanismos de associação (HUME 32, p. 126). Que os três mecanismos têm esse efeito sobre as ideias parece não haver dúvida. O retrato de um amigo sempre faz com que eu o conceba em minha imaginação de maneira mais vívida. Do mesmo modo, quando vejo um lugar qualquer próximo à minha casa, a ideia desta ganha maior força. Com relação à associação por causa e efeito, também transmite sua vivacidade às ideias relacionadas a ela, como podemos atestar pelos exemplos referentes a relíquias de santos (tratadas como efeitos dos santos) e à visita do filho de um amigo.

Logo em seguida, Hume afirma que em todos esses fenômenos (inclusive naqueles que dependem da relação de causa e efeito), “a crença no objeto correlato está

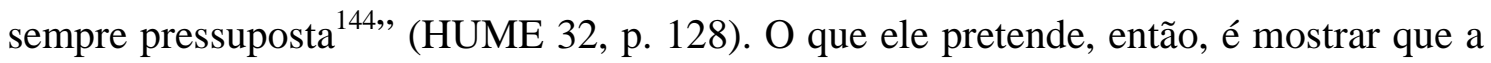
crença, quando vai além da memória ou dos sentidos, também opera por um mecanismo de transferência de vivacidade. Quando atiro ao fogo um pedaço de madeira, minha mente é imediatamente levada a conceber que isso fará com que o fogo aumente, não

\footnotetext{
${ }^{143}$ É verdade que Hume emprega, por vezes, o termo relação para se referir à crença causal, mas isso não basta para que a consideremos um mecanismo de associação que segue os mesmos moldes que aqueles observados nos mecanismos "estritamente" associativos de semelhança, contiguidade e causa e efeito.

144 “[...] the belief of the correlative object is always pressuposed [...]”.
} 
diminua. Do mesmo modo, quando uma espada é levantada contra meu peito, as ideias de ferimento e de dor me atingem com mais vivacidade do que quando me é apresentada uma taça de vinho, mesmo que, por motivos acidentais, eu seja acometido por alguma dor quando estou na presença da taça em questão (HUME 32, p. 129). Tudo o que Hume pretende afirmar, então, é que a crença causal também opera por meio da transferência de vivacidade da impressão presente para uma ideia correlata, o que também ocorre no caso dos três mecanismos de associação. Estes, como já vimos, dependem de uma crença anterior para terem seu efeito vivificante. Mesmo a associação causal só pode surgir depois de estabelecida a crença.

A instituição da crença por repetições constantes e, portanto, pelo costume, também está presente na versão da teoria do conhecimento humiana exposta no Tratado. Na Seção 8 da Parte 3 do Livro 1, temos a seguinte explicação acerca da origem da crença causal:

[...] Agora, como chamamos costume tudo aquilo que procede de uma repetição passada, sem qualquer raciocínio ou conclusão novos, podemos estabelecer como uma verdade certa que toda crença que se segue a qualquer impressão presente é derivada apenas dessa origem $^{145}$. (HUME 31, pp. 71-2)

Pode parecer, então, que nesse aspecto Hume não apresenta, na primeira Investigação, grandes mudanças com relação à teoria da crença causal exposta no Tratado. Neste, entretanto, ao fazer referência aos mecanismos de associação de ideias, Hume dá os exemplos referentes à semelhança e à contiguidade para, logo em seguida, dizer que a causalidade tem "a mesma influência que as outras duas relações ${ }^{146 "}$ (HUME 31, p. 70). Cita, então, o conhecido exemplo das relíquias de santos, que tratamos de mostrar que seria aproveitado para defender algo diferente na primeira Investigação, ou seja, que a crença causal e a relação causal são coisas diferentes. Quanto ao texto do Tratado, parece que apresenta certa confusão. E para deixar tudo ainda mais complicado, a passagem que citamos acima é apresentada depois que nosso

\footnotetext{
145 "Now as we call every thing custom, which proceeds from a past repetition, without any new reasoning or conclusion, we may establish it as a certain truth, that all the belief, which follows upon any present impression is deriv'd solely from that origin”.

146 “[...] has the same influence as the other two relations”.
} 
filósofo afirma que a relação de causa e efeito pode avivar ideias e, portanto, gerar crença. Desse modo, duas possibilidades se colocam para nós. A primeira é que o costume contribui para a crença que, por sua vez, pode estar de algum modo contida na associação por causa e efeito, a qual seria, por sua vez, a base para o conhecimento do mundo percebido. A segunda é que a crença é resultado direto do hábito (ou costume) e, a partir dela, torna-se possível o surgimento da relação de causa e efeito, que, posteriormente, terá, como as relações de semelhança e de contiguidade, o poder de aumentar a vivacidade de ideias que concebamos como participantes dessa relação. Vejamos, então, qual dessas duas possibilidades é efetivamente defendida no Tratado.

Como já dissemos, os aspectos básicos do argumento sobre os raciocínios sobre causa e efeito que vemos no Tratado pode ser visto nas seções 6 a 8 da Parte 3 do Livro 1. Na Seção 6, Hume afirma que a razão é incapaz de chegar à "conexão última” entre causas e efeitos e, mesmo depois de informados pela experiência, estamos restritos aos casos particulares que contemplamos, ainda que, é claro, tenhamos uma propensão a projetar no futuro os casos passados quando acontecem semelhanças entre eles (sendo essa a única "garantia” para a crença). A transição de causas a efeitos é feita por um princípio de "união” entre as ideias (HUME 31, p. 64). Esse é o nome que Hume dá, nesse momento, às relações de semelhança, contiguidade e causa e efeito. O costume será apresentado, então, como um princípio que parece bastante diferente deles, mas que Hume afirma depender da mesma origem. Pode ser oportuno lembrar, também, que nosso filósofo tem, nesse parágrafo, o cuidado de afirmar que os três princípios de associação não são infalíveis, nem a única causa da união entre ideias.

Logo em seguida, retomando a teoria das ideias abstratas de caráter berkeleyano desenvolvida no final da primeira parte do Livro 1, Hume mostra como, a partir do costume, construímos uma relação entre palavras e ideias que permite que unamos na imaginação certas palavras a grupos inteiros de objetos entre os quais percebemos certa semelhança. Então, nosso filósofo afirma que esse princípio (o costume) é um verdadeiro "princípio de associação entre ideias", e afirma que ele é "o mesmo que ocorre entre as ideias de causa e efeito, e é uma parte essencial em todos os nossos raciocínios a partir dessa relação $^{147, ”}$ (HUME 31, p. 65 - itálico nosso). Parece que o

147 “[...] a true principle of association among ideas, I assert it to be the very same with that betwixt the ideas of cause and effect, and to be an essential part in all our reasonings from that relation". 
Hume do Tratado, diferentemente do da primeira Investigação, considera a causalidade o tempo todo enquanto uma relação de ideias, aquela arrolada juntamente com a semelhança e a contiguidade ${ }^{148}$. Isso parece ser confirmado na Seção 9, em que ele afirma que, como a causalidade, as “outras duas relações” devem ser vistas como capazes de levar a imaginação de uma ideia à outra. Essa passagem não seria tão digna de nota se não estivesse inserida no contexto de uma longa discussão em que distinguir a causalidade como relação de outro possível sentido para esse termo se torna praticamente impossível. Ainda, como vimos, além de Hume se referir à associação causal de um modo que não permite que a distingamos da crença causal $e$ de uma relação entre três, não há passagens em que nosso autor se preocupa em diferenciar esses dois fenômenos, diferentemente do que podemos ver na primeira Investigação. Nesta, como já dissemos, a crença causal é apresentada não como indistinguível da relação de causa e efeito, mas como algo que surge antes dela, e de que ela depende. Nesse sentido, a primeira Investigação apresenta a crença não como resultado de uma

${ }^{148}$ Em um artigo chamado Associação e Crença Causal em David Hume, João Paulo Monteiro afirma que mesmo no Tratado Hume não estabelece que a relação de causa e efeito é a base pela qual raciocinamos sobre questões de fato e já é considerada diferente da crença causal. Ora, como dissemos, o costume (e, portanto, a crença) são apresentados, no Tratado, não como a mesma coisa que a relação causal, mas como parte dela, o que já está em desacordo com a interpretação feita por Monteiro. Acreditamos que o modo como Hume constroi seu argumento, a partir da passagem da Seção 8 da Parte 3 do Livro 1 (na qual, logo antes de oferecer o exemplo das relíquias, trata da causação como uma relação) é decisivo, até pela preocupação evidente, por parte de Hume, em reestruturar esse argumento na primeira Investigação. É claro que isso pode significar que nosso autor percebeu que a maneira como essa passagem do Tratado estava estruturada poderia gerar confusões, mas ele não faz grandes esforços posteriores para corrigir essas confusões. No início da Seção 9 da Parte 3 do Livro 1, isso culmina com o fato de ele não ter alternativa a não ser tratar causa e efeito simplesmente como uma relação, como buscamos mostrar no corpo do texto. Seria possível afirmar que Hume não pretendia tecer no Tratado uma teoria eminentemente associacionista, mas terminou enredado no aparato que já estava construído como preparação para a Parte 3 do Livro 1, e acreditamos ter sido esse o caso. Sabemos, afinal, que Hume considera ter cometido uma série de erros juvenis no Tratado e que, se esse aspecto muda na primeira Investigação, é provável que o associacionismo mais “forte” presente no Tratado tenha sido um deles.

Voltando ao artigo de João Paulo Monteiro que estamos discutindo nesta nota, devemos observar, ainda, que não há evidências textuais suficientes para que vejamos no Tratado os dois sentidos de associação por ele propostos. Além disso, faltou a esse comentador observar, ao fim de seu artigo, que os mecanismos de associação, do modo como Hume os apresenta na primeira Investigação, não parecem ser tratados ainda como tão suaves quanto pareciam ser no Tratado. 
associação no sentido "técnico" que esse termo tem nas obras de Hume, mas como uma expectativa que surge automaticamente por meio do hábito. Se este ainda surge de causas similares àquelas que regem os princípios de associação, é apenas porque, como eles, funciona pela transferência automática de vivacidade, a qual independe de qualquer processo racional ${ }^{149}$.

De qualquer maneira, para os fins que temos em vista, basta que reconheçamos que, tanto no Tratado quanto na primeira Investigação, Hume estabelece que não temos qualquer ideia de uma característica na causa pela qual seria possível inferirmos racionalmente, a partir dela, seu efeito. Nos dois escritos, a repetição e, portanto, o costume é que engendra a crença que é, em última instância, o fundamento de nossos raciocínios por causa e efeito. Existe, porém, um aspecto com o qual não podemos nos abster de lidar: nos dois textos de que estamos tratando, a mera repetição é capaz aumentar a vivacidade de uma ideia, contribuindo para que ela se torne uma crença. No Tratado, isso parece alcançar um ponto realmente problemático, em que a educação se torna capaz de sobrepujar, em muitos casos, a própria experiência, simplesmente exercer, desde a mais tenra infância, a repetição exaustiva de determinadas ideias. No Tratado, só o que Hume pode fazer quanto a isso é afirmar que temos aí uma confirmação da tese de que a repetição aumenta a vivacidade com que percebemos uma ideia e que essa vivacidade é a própria crença (HUME 31, p. 80). Na Investigação, porém, o problema parece ter sido eliminado com a consideração de que as conclusões baseadas na experiência são, em última instância, simplesmente irresistíveis, já que a crença é lá apresentada como sendo “o resultado necessário de se colocar a mente em tais circunstâncias [as que resultam de conjunções constantes repetidas inúmeras vezes] ${ }^{150, " ~(H U M E ~ 32, ~ p . ~} 123$ - itálico nosso). Isso exige, é claro, que o hábito nos predisponha a esperar que as conjunções observadas no passado se repitam no futuro, o que Hume prontamente admite tanto no Tratado quanto na primeira Investigação. No fim das contas, a conclusão é que, mesmo afirmando, ao tratar mais especificamente da

\footnotetext{
149 De modo geral, então, tendemos a concordar com a interpretação que James Noxon oferece, a esse respeito, em seu Hume’s Philosophical Development. Parece-nos que há, no Tratado, uma forma bastante forte de associacionismo que é atenuada na primeira Investigação, na qual o modo como a crença se estabelece não depende de um “princípio de associação” no sentido estrito.

150 “[...] the necessary result of placing the mind in such circumstances [...]”
} 
conexão necessária, que não temos qualquer ideia de um "poder” presente na causa que faz com que ela "produza" o efeito, somos levados irresistivelmente, por meio do aumento cada vez maior de vivacidade que é o efeito inevitável do hábito, a conceber, a partir da presença de um dos dois elementos aos sentidos ou à memória, o seu correlato, de maneira muito mais vivaz do que qualquer ideia invocada de maneira puramente arbitrária. É assim que somos levados a esperar que uma bola de bilhar, ao se chocar com outra, faça com que ela se mova, ou que os pães que comermos nos alimentem como já haviam feito os pães que comemos anteriormente ${ }^{151}$. Nos dois casos, temos uma crença que deriva de um objeto presente à memória ou aos sentidos e de uma conjunção constantemente observada no passado.

Temos aí um dos recursos usados por Hume para estabelecer o primado da experiência sobre a educação e sobre os testemunhos. Ainda que no Tratado essa proposta pareça enfraquecida, é sintomático o fato de mesmo nessa obra a credulidade e os preceitos que nos são inculcados desde a infância terem uma explicação eminentemente causal. Os discursos são mostrados como tendo relação com certas ideias que se apresentam a nossos interlocutores e essas ideias, por sua vez, estão relacionadas a fatos ou a objetos por elas representados (HUME 31, p. 78). Parece, então, que é saudável que possamos confiar no que nos dizem nossos convivas e nossos mestres. De maneira geral, isso parece, também, importante para um filósofo que defende certo caráter social da filosofia, e já esclarecemos de maneira razoavelmente satisfatória que esse é o caso de Hume, mesmo que ainda não tenhamos extraído todas

${ }^{151}$ Como observa Peter Jones em seu Hume’s Sentiments, é inegável que a doutrina de nosso filósofo segundo a qual não podemos perceber qualquer ideia de poder na causa tem forte inspiração em Malebranche. Mesmo os exemplos das bolas de bilhar e dos pães, aparentemente, foram extraídos de seu La Recherche de La Verité (JONES 45, pp. 24-6). Isso explica, ao menos em parte, o grande cuidado mostrado por Hume em se distanciar do ocasionalismo ao tratar da ideia de conexão necessária. Não trataremos em detalhes, é claro, do modo como isso é feito, já que isso nos distanciaria dos propósitos deste trabalho, mas é interessante indicarmos os argumentos que Hume emprega contra o ocasionalismo: 1 - ele “torna” Deus menos perfeito, já que supõe que Ele não poderia simplesmente criar um mundo que funciona a contento por si só; 2 - ele está tão distante da experiência que não poderia causar grande convicção, mesmo com argumentos bem elaborados; 3 - de qualquer maneira, os argumentos ocasionalistas não são bem fundamentados, já que dependem da aceitação de que compreendemos como uma mente “atua sobre” a matéria (o que parece ocorrer no caso, por exemplo, da vontade movendo os músculos), mas, como se sabe, Hume não acredita que temos esse tipo de compreensão. 
as consequências desse aspecto de seu pensamento. De qualquer modo, é preciso estabelecer certos critérios pelos quais possamos verificar a confiabilidade de certos testemunhos e, é claro, daquilo que nos é ensinado. Poderíamos dizer que o estudo que Hume empreende sobre a probabilidade é uma ferramenta interessante para esse fim, mas, para que ela possa ser usada, seria preciso que a experiência já estivesse plenamente estabelecida como algo que tem caráter normativo. No Tratado, ainda que esse ponto pareça ser afirmado de maneira mais fraca, poderíamos dizer que ele se completa na Parte 4 do Livro 1, em que a ficção da existência contínua e independente dos objetos é considerada algo simplesmente irresistível. Tanto a seção "Da Filosofia Antiga” quanto a "Conclusão" afirmam que, mesmo que asserções como a existência contínua sejam fictícias, elas são simplesmente irrecusáveis, são naturais no sentido de que são necessárias e, por isso, devem ser aceitas pelo verdadeiro filósofo. Ora, como vimos, a crença causal deriva sua força de um processo que tem início precisamente em impressões que certamente podemos esperar que correspondam aos objetos a que atribuímos a tal existência contínua de que não temos como duvidar. Isso não apenas explica por que a educação, por mais força que possa adquirir em certos casos, tem, de maneira geral, menos força que a experiência, mas também garante para esta última se apresenta como normativa: dela, e unicamente dela, não nos é possível duvidar. Ainda assim, parece que a maneira como esse ponto é conduzido no Tratado é um tanto insatisfatória, já que Hume chega a admitir que a educação pode efetivamente contrabalançar a experiência.

Esse definitivamente não chega a ser um problema no caso da primeira Investigação, já que nela a crença em objetos que fundamentam quaisquer relações entre ideias é pressuposta para que elas possam avivar outras ideias atinja grau considerável. Além disso, como já vimos, o Hume da Investigação apresenta a crença como um resultado inevitável. Mais do que isso, ao fim da Seção 5, ele afirma que os princípios que asseguram a crença são os mais conformes à "sabedoria ordinária da natureza” no que diz respeito à garantir a nossa conservação. Vale também lembrar que, nesse mesmo parágrafo, eles são considerados infalíveis (HUME 32, pp. 129-30).

Fica evidente, então, que o caráter normativo da experiência fica estabelecido nos dois textos em bases muito semelhantes, ainda que a estrutura e o vocabulário adotados no Tratado, de certo modo, enfraqueçam esse ponto. Isso não quer dizer, é claro, que a educação e os testemunhos não componham parte importante de nossas 
crenças, mas permite que vejamos na experiência um critério para distinguirmos quais dos conceitos que nos são transmitidos pelos outros podem ser considerados confiáveis. Isso fica evidente, por exemplo, na Seção 10 da primeira Investigação, em que a não conformidade com a experiência é vista como razão para rejeitar quaisquer relatos miraculosos. "Um homem sensato”, diz Hume, "proporciona sua crença à evidência ${ }^{152, "}$ (HUME 32, p. 170). A evidência, é claro, é fornecida pela experiência, que, quando se mostra infalível, permite que esperemos, com a máxima certeza, a repetição futura das conjunções por ela estabelecidas.

Isso não quer dizer, é claro, que toda conclusão oferecida pela experiência seja infalível. As conclusões que se mostraram infalíveis são chamadas por Hume de provas, e não deixam qualquer espaço para dúvida. Isso não quer dizer que elas pressuponham quaisquer garantias ontológicas. Em uma divisão como a de Locke, em que os raciocínios se dividem apenas em demonstrativos e prováveis, é apenas provável que o sol nasça amanhã, ou que o choque de uma bola de bilhar provoque o movimento de outra. No entanto, como vimos, a experiência oferece, para Hume, garantias inegavelmente confiáveis de que poderemos continuar a confiar nesse tipo de conclusão. Ocorre, porém, que existem conclusões experimentais que mesmo Hume chama apenas de prováveis. Isso porque, ainda que não haja algo como o acaso, nossa ignorância acerca da causa real faz com que tenhamos apenas uma crença mais fraca (HUME 32, p. 131). É claro que há situações em que parece haver apenas uma "probabilidade de chances”. Se um dado, por exemplo, tem quatro de suas faces pintadas com uma figura e duas pintadas com outra, consideramos mais provável que, ao lançamento do dado, “saia” a figura que está presente em quatro faces. Isso porque a mente, ao se debruçar sobre o evento mais provável, considera que cada face tem uma chance igual. Assim, somamos as chances das quatro faces e as colocamos "contra" as das outras duas. A mente, então, é levada a conceber de maneira mais vivaz a chance de "sair" a figura presente em quatro faces.

Para Hume, o caso é bem semelhante com a probabilidade de causas. Algumas causas são, para ele, menos constantes em acarretar o efeito que seria esperado. Exemplos incluem o ruibarbo, que não apresenta efeito purgativo em todos os casos, e o ópio, que nem sempre se mostra um soporífero eficiente. A grande diferença em relação

\footnotetext{
152 "A wise man, therefore, proportions his belief to the evidence".
} 
à probabilidade de chances é que "filósofos não atribuem esse fenômeno a qualquer irregularidade da natureza, mas supõe que algumas causas secretas, na estrutura

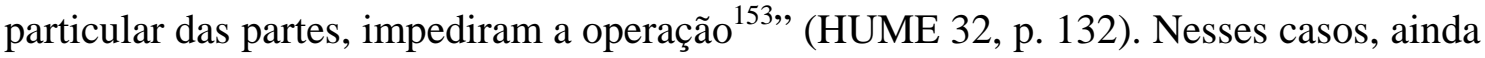
somos levados, quando a causa está presente, a esperar igualmente o surgimento do efeito. O caso é mais complicado quando se acredita que efeitos diferentes teriam sido provenientes de certas causas. Nesse tipo de situação, a mente transmite para suas expectativas futuras o mesmo grau de incerteza observado no passado, ainda que a preferência ainda seja dada ao evento mais usual.

Esses aspectos da teoria do conhecimento humiana permitem que realizemos mais algumas considerações sobre a confiabilidade dos testemunhos. Mesmo que concedamos que os homens têm certa tendência a dizer a verdade, existem "causas secretas”, como superstições religiosas e paixões particulares, que podem fazer com que o efeito “dizer a verdade” não apareça de maneira completamente uniforme. E mesmo sem considerar esse tipo de inconstância nas causas, poderíamos simplesmente considerar que existem situações em que os homens mentem e, ainda que elas possam não ser muito mais frequentes do que aquelas em que dizem a verdade, são suficientes para que a mente realize a transferência do "evento mais usual" sem conceder a ele tanta vivacidade. No fim das contas, o que ocorre é que não há como um homem sensato considerar mais provável um evento completamente oposto à experiência mais provável que o fato de pessoas incultas e predispostas à superstição estarem certas quando relatam milagres. No fim das contas, a experiência, além de fornecer conclusões infalíveis com relação às quais não podemos simplesmente recusar por conta de alguns relatos, permite que expliquemos de maneira satisfatória por que tais relatos interferem com o curso normal da confiabilidade dos testemunhos.

Parece-nos que a discussão sobre a influência da educação no Tratado não pode ser dissociada daquela que diz respeito aos testemunhos. Em ambos os casos, o que temos é uma série de opiniões potencialmente errôneas que somos levados a aceitar à revelia da experiência. Ora, estabelecido o primado desta última, fica evidente o potencial que ela tem para corrigir as falsas crenças estabelecidas pela educação. As máximas que esta propõe são ocasionalmente contrárias não apenas à razão (entendida,

153 “"...] philosophers ascribe not this to any irregularity in nature; but suppose, that some secret causes, in the particular structure of parts, have prevented the operation". 
aqui, como o raciocínio experimental), mas também a si mesmas (HUME 31, p. 81). Ora, em uma situação em que elas contrariem a umas às outras, o único critério que temos para julgá-las é a experiência. E quando forem contrárias à razão, certamente poderão ser corrigidas por uma atividade reflexiva. Não fosse esse o caso, continuaríamos a acreditar, por exemplo, que beber leite com manga causa dor de estômago, mesmo que alguém nos enganasse para que o bebêssemos e pudéssemos verificar, então, que a tal dor não se sucedeu. No fim das contas, a experiência pode ser usada, tanto no caso dos testemunhos quando no da educação, não apenas para corrigilos, mas, também, como já deve estar evidente, para explicar de que maneira eles são capazes de provocar crenças. E se houver casos em que testemunhos ou educação buscam inculcar princípios que fogem ao alcance da experiência, ela mesma será capaz de denunciar tal procedimento, como teremos a oportunidade de observar posteriormente. Concluímos, então, que mesmo que o Tratado possa ser visto como algo problemático nesse por não permitir a explicitação imediata do papel normativo da experiência, abrindo espaço para problemas sérios advindos da força da educação e dos testemunhos, uma leitura contextualizada, auxiliada pelo recurso ao texto da primeira Investigação, permite que esse problema seja dirimido. Acreditamos que seria possível que Hume houvesse oferecido já no Tratado uma solução mais satisfatória para essa questão e, se não o fez, foi porque ela surgiu em uma seção em que a principal preocupação era estabelecer a capacidade dos princípios de associação de vivificarem ideias e, é claro, a capacidade que o hábito também tem de fazê-lo, e assim criticar qualquer concepção filosófica segundo a qual a razão, em seu sentido demonstrativo, é capaz de gerar uma crença do tipo da que ocorre nas relações causais. Talvez nosso filósofo tenha reconhecido que o problema gerado era um preço alto demais e, assim, tenha buscado afirmar o caráter "inescapável” da experiência em cores mais fortes na primeira Investigação.

De qualquer maneira, a influência da educação não é o único efeito negativo que pode surgir de funcionamentos da natureza humana que não são "sancionados pelos filósofos”. No Tratado da Natureza Humana, Hume trata daquilo que chama de probabilidades não filosóficas, que se devem a princípios da natureza humana, mas não são exatamente confiáveis no que concerne o conhecimento das coisas que julgamos por causa e efeito. Demorar-nos-emos apenas no quarto tipo de probabilidade não filosófica, que parece particularmente interessante para compreendermos um aspecto importante 
da epistemologia humiana e, também para mostrarmos outro exemplo de afirmação do caráter normativo da experiência.

O tipo em questão diz respeito à formação de causas gerais formadas de maneira precipitada que, segundo Hume, são responsáveis por aquilo a que chamamos preconceitos. É por esse tipo de fenômeno que podemos passar a acreditar, por exemplo, que irlandeses não podem ser espirituosos ou que franceses são necessariamente fúteis (se quisermos usar exemplos mais familiares, podemos dizer que tal princípio nos faz acreditar que os baianos são invariavelmente preguiçosos e que os argentinos são todos convencidos). O que acontece em casos como esses é que, quando observamos dois objetos frequentemente juntos, a imaginação, por uma transição natural que precede qualquer reflexão, passa imediatamente de um objeto a outro. Isso ocorre porque tendemos, nesse tipo de engano, a misturar à causa verdadeira certos fatores que acidentalmente a acompanhavam. Nesses casos, Hume considera que o costume, ainda que seja o fundamento de nossos juízos, pode, ao permitir generalizações que são decorrentes apenas de uma tendência da imaginação a ir longe demais ou a não separar a causa de fatores supérfluos que a acompanham, mostrar-se contrário ao juízo. No Tratado, Hume menciona a reflexão como algo que pode corrigir esse tipo de raciocínio não confiável que é, como vimos, motivado pelo hábito. A reflexão aparentemente poderia ser empregada, também, para corrigir outros tipos de probabilidade não filosófica, como a tendência a conferir a probabilidades a mesma força que atribuímos a provas e aquela a assentirmos menos a experiências acontecidas há muito tempo. Essa solução, entretanto, não é desprovida de complicações, já que Hume não dá maiores explicações sobre o modo como funcionaria a reflexão. Parece que ela seria apenas uma operação consciente em que tentamos trazer à mente apenas a noção de que as mesmas causas produzem sempre os mesmos efeitos e, é claro, tentamos, também, ver claramente apenas a própria causa, sem nada que possa tê-la acompanhado acidentalmente.

Na Investigação, a única vez em que algo desse tipo se faz notar é em uma nota ao quinto parágrafo da Seção 5 e, nela, só o que Hume diz é que a própria experiência nos ensina os limites apropriados de cada máxima (HUME 32, p. 122). A única conclusão a que a nota chega, então, é que existem pessoas que raciocinam de maneira mais ou menos perfeita conforme sua, digamos, experiência de vida. No Tratado, porém, aquilo a que Hume havia chamado reflexão é de suma importância para que 
aprendamos de que maneira estabelecer os princípios corretos do raciocínio causal, tal como estão expressos nas "regras para se julgar sobre causas e efeitos" que constituem a Seção 15 da Parte 3 do Livro 1. Acreditamos que as duas obras, nesse aspecto, não são contraditórias. A reflexão como método de "limpeza” de uma consideração sobre causa e efeito, responsável por fazer com que sejamos capazes de distinguir o que é suficiente para estabelecer algo como uma causa, não é explicitamente negada na primeira Investigação. O que ocorre é que esta deixa claro que um número maior de experiências certamente é útil para que possamos compreender melhor o modo como funciona a relação de causa e efeito, o que certamente nos faria prestar mais atenção àquilo que é verdadeiramente a causa, com base no que Hume considera serem ocasiões apropriadas. Portanto, a reflexão parece ser não algo que exclui esse refinamento gradual da experiência, mas sim algo que pode contribuir para que ele ocorra. De qualquer modo, mesmo que seja mais difícil ver na primeira Investigação algo como uma atividade reflexiva propriamente explicada, parece haver algo como um mecanismo confiável de correção dos “maus hábitos” pela própria experiência, que, com o tempo, mostra-nos quais são as relações causais em que efetivamente podemos confiar.

\section{Ceticismo, naturalismo, realismo, vida comum}

Depois dessa análise da epistemologia humiana, que reconhecemos estar longe de esgotar todos os problemas que ela apresenta, podemos retornar ao debate entre os partidários do "velho Hume” e os do "novo Hume”. Acreditamos que a leitura que fizemos dos principais aspectos da teoria do conhecimento desenvolvida por nosso filósofo será suficiente para que definamos em que medida ceticismo e realismo (e, em certa medida, ceticismo e naturalismo) se misturam em sua obra e, em seguida, o que isso permite que digamos acerca da própria concepção de filosofia esposada por Hume.

Como vimos, a "Conclusão” do livro 1 do Tratado da natureza humana partia de um princípio em que Hume, ao encarar as consequências do ceticismo decorrente de sua teoria do conhecimento, considerava-se desesperado de encontrar qualquer certeza em suas investigações. Depois de uma série de revoluções, por assim dizer, dialéticas, o protagonista dessa seção teria sido salvo pela natureza, que, além de devolver a ele seu status de ser social, propôs uma maneira de filosofar que, além de motivada por propensões e inclinações pessoais, admitia, em sua própria maneira de ser, esses 
mesmos princípios. O ponto atingido no final da “Conclusão” do Livro 1 é, portanto, um ponto em que certas inclinações devem ser aceitas simplesmente porque não temos a menor possibilidade de recusá-las. O filósofo que se dedica a suas especulações motivado pela natureza, como o homem comum, submete-se ela, e é aí que mostra com mais exatidão seus princípios, que, nessa seção, Hume denomina céticos. Não podemos nos esquecer de que Hume afirma a necessidade de comunicar aos filósofos a "mistura terrena grosseira” que caracteriza o homem comum. Esse é o único modo pelo qual ele considera que seria possível estabelecer princípios filosóficos capazes de resistir ao teste do tempo. Não é mero artifício retórico, então, a afirmação, no início do tratamento conferido por Hume ao ceticismo concernente aos sentidos, de que o cético deve assentir à ideia da existência de corpos porque a natureza não deixou isso à sua escolha. O mesmo pode ser dito do encerramento da Seção 5 da primeira Investigação, em que Hume considera que o raciocínio mecânico e instintivo que permite o estabelecimento da relação de causa e efeito teria sido implantado em nós pela natureza simplesmente porque a razão, lenta e falível, não seria capaz de garantir nossa sobrevivência e/ou nossas necessidades práticas. Isso é confirmado quando, ao discorrer sobre a razão dos animais, nosso filósofo deixa claro que o raciocínio experimental, compartilhado por nós e por eles, e dos quais nossas vidas certamente dependem, “não é nada além de uma espécie de instinto ou de poder mecânico, que age em nós sem o nosso conhecimento e, em suas principais operações, não é dirigido por quaisquer relações ou comparações de ideias que sejam os objetos apropriados de nossas faculdades intelectuais ${ }^{154 \text { ", }}$ (HUME 32, p. 168). A conclusão é, então, que Hume certamente admite que todo o nosso conhecimento do mundo tal como o percebemos depende de algo como um instinto. Dependemos de princípios naturais inescapáveis que tornam irresistíveis certos pontos de partida que podem ser fictícios, mas nos quais certamente é melhor que acreditemos. Por mais que não tenhamos como fundamentar a existência contínua dos corpos ou a relação de causa e efeito, é inegável que, a não ser de certa maneira puramente hipotética, a qual não é capaz de causar qualquer convicção a ninguém que não esteja profundamente transtornado, é impossível não assentir de imediato a esses fenômenos. Ao dizer que a natureza o salva, Hume rompe irremediavelmente com uma leitura que o

\footnotetext{
154 “[...] is nothing but a species of instinct or mechanical power, that acts in us unknown to ourselves; and in its chief operations, is not directed by any such relations or comparisons of ideas, as are the proper objects of our intellectual faculties".
} 
associe ao ceticismo pirrônico contra o qual, aliás, ele parece, ao longo de praticamente toda a sua obra, sustentar todos os preconceitos típicos de sua época. O pirrônico é, para Hume, o cético melancólico que está completamente impedido de agir ou de pensar por conta dos simples efeitos de sua própria filosofia. Ainda que, como Hume nos lembra na Seção 12 da primeira Investigação, seja saudável empregarmos uma pequena dose de pirronismo para não nos tornarmos demasiadamente obstinados em nossas opiniões, é impossível sustentar o tempo todo uma atitude como essa. Isso não porque uma atitude pirrônica não pode ser, por si só, algo poderoso, o que ela certamente é, ou não teria bastado para levar o protagonista da "Conclusão" do Livro 1 do Tratado ao estado mais melancólico possível. Ocorre, porém, que a natureza, como já vimos, vem em socorro de nosso filósofo e o liberta de sua letargia. Mas é claro que a natureza não salva todos os aspectos sobre os quais os pensadores costumam raciocinar. O que ela salva são as mesmas concepções que ela trata de nos impor de maneira inevitável, de modo que é apenas a partir delas que podemos pensar em construir uma filosofia consistente. Por isso é que um julgamento correto, "evitando todas as investigações distantes e elevadas, confina-se à vida comum, e a objetos tais que se referem à prática diária e à experiência ${ }^{155, " ~(H U M E ~ 32, ~ p . ~ 208) . ~ N e s s e ~ a s p e c t o, ~ t e m o s ~ p l e n a ~ c o n c o r d a ̂ n c i a ~}$ entre o Tratado e a primeira Investigação. Nos dois escritos, a natureza nos salva ao impor certas crenças de acordo com as quais conduziremos tanto nossas vidas quanto nossas investigações filosóficas, independente de podermos ou não fundamentar essas crenças. E é a partir dessas crenças, que se mostram suficientemente regulares e confiáveis, que Hume pretende construir sua filosofia, que corresponderá, no fim das contas, às reflexões da vida comum, metodizadas e corrigidas (HUME 32, p. 208). O cético ainda poderá obter triunfos reais, mas apenas em esferas distantes daquela em que a natureza vem prontamente em nosso socorro. Nessas, de fato, é possível que sejamos incapazes de resistir a quaisquer tentativas de solapar nossas convicções. Entretanto, como vimos, essas são as regiões que, mesmo que possamos pretender que digam respeito a um pretenso mundo real, estão completamente fora do alcance de qualquer convicção, ao menos no caso daqueles que Hume denomina homens sensatos, de modo que o triunfo do pirrônico parece ter sido um tanto esvaziado.

\footnotetext{
155 “[...] avoiding all distant and high enquiries, confines itself to common life, and to such subjects as fall under daily practice and experience [...]”
} 
Tudo isso dito, parece evidente que aqueles que têm defendido um naturalismo forte em Hume o fazem com no mínimo alguma razão. É verdade que tudo que nosso filósofo chama de "natureza” pode ser considerado como uma construção e que, nesse sentido, nossas propensões não podem ser consideradas como fruto de uma possível realidade externa a que estamos sujeitos. Mas ainda assim, não podemos perder de vista que essa natureza é tratada, ao longo de toda a obra de Hume, como uma série de princípios que, se por um lado não tem sua “origem” determinada, é certamente responsável pelo estabelecimento de princípios que governam cada instante da vida de todos nós, filósofos ou não. Nesse sentido, é impossível negar que existe, na obra de Hume, uma forma bastante forte de naturalismo.

Entretanto, o debate mais recente sobre a teoria do conhecimento humiana, aquele entre os defensores do "velho Hume" e os do "novo Hume", não é entre defensores de que o filósofo escocês seria cético ou naturalista. Esse debate se dá em termos um tanto diferentes, e ocorre entre aqueles que vêem em Hume alguma forma de realismo causal e aqueles que não identificam essa característica na obra de nosso autor. A questão passa a ser, portanto, não ceticismo $\mathrm{X}$ naturalismo, mas ceticismo $\mathrm{X}$ realismo. Se aqueles que defendem realismo causal na obra de Hume estiverem corretos, nosso autor não considera apenas que devemos assentir à crença causal, ou que não podemos resistir a ela. Aqueles que atribuem a Hume uma postura que pode ser definida por realismo causal o fazem porque acreditam que a filosofia humiana considera que, além disso, existem boas razões epistemológicas para que acreditemos que a relação de causa e efeito é algo que acontece em um mundo exterior às nossas mentes que, justamente por ser exterior, pode ser chamado de "mundo real" em um sentido próximo daquele que comumente atribuímos a essa expressão ${ }^{156}$.

Os defensores do "novo Hume” têm por hábito priorizar a Investigação sobre o entendimento humano. Esse é um procedimento que faz sentido, já que o próprio Hume nos fez, a certa altura, essa recomendação. Ainda assim, existe um outro motivo para que eles o façam: é evidente que eles sabem que há várias passagens no Tratado em que

\footnotetext{
${ }^{156}$ A expressão "realismo causal teria sido aplicada a Hume pela primeira vez nos escritos de John P. Wright. Isso não quer dizer, é claro, que ele seja o único a defender uma leitura que atribui a Hume uma postura como essa. Existem outros defensores bastante ferrenhos do "novo Hume", talvez até mais do que Wright, como Galen Strawson.
} 
nosso filósofo afirma claramente que a razão não nos oferece qualquer justificativa para a crença na existência de corpos, como, por exemplo, a seguinte, extraída da Seção 5 da Parte 3 do Livro 1:

Quanto às impressões que surgem dos sentidos, sua causa última é, em minha opinião, perfeitamente inexplicável pela razão humana, e será sempre impossível decidir com certeza se elas surgem imediatamente do objeto, ou se são produzidas pelo poder criativo da mente, ou se são derivadas do autor de nosso $\operatorname{ser}^{157}$. (HUME 31, p. 59)

Essa passagem é bastante clara: no que diz respeito às impressões que constituem o fundamento último de todos os nossos raciocínios experimentais, só o que podemos afirmar é que elas se apresentam como inevitáveis e dotadas de enorme vivacidade $^{158}$. A razão demonstrativa não é capaz de mostrar qual é a origem delas e,

157 "As to those impressions, which arise from the senses, their ultimate cause is, in my opinion, perfectly inexplicable by human reason, and 'twill always be impossible to decide with certainty, whether they arise immediately from the object, or are produc'd by the creative power of the mind, or are deriv'd from the author of our being".

158 Strawson, quando recorre ao Tratado, ignora essa passagem de maneira aparentemente proposital, preferindo afirmar que uma outra, segundo a qual não podemos conceber algo especificamente diferente de ideias e impressões, quer dizer apenas que não podemos conceber nada de "uma espécie diferente". Parte daí para defender que, mesmo assim, podemos ter "alguma ideia” do que causa as impressões por meio do conceito de "ideia relativa", que aparece no contexto das discussões sobre espaço e tempo, considerando que a ideia relativa do que causa a impressão equivale a uma suposição algo indefinida do que poderia ter causado a impressão (STRAWSON 91, p. 38). Estrategicamente, Strawson deixa de lado a continuação da passagem, na qual Hume explica que isso quer dizer que supomos que os objetos que causam as impressões não são especificamente diferentes, mas podem ter relações diferentes das observadas nas impressões (HUME 31, p. 49). Nesse ponto, uma nota nos remete para seção "Do Ceticismo quanto aos Sentidos”, em que, como já vimos, Hume defende explicitamente que não temos qualquer motivo epistemologicamente viável para acreditar em objetos externos, e é exatamente por isso que só o que nos resta quanto a essa questão é a tábua de salvação oferecida pela natureza.

Quanto à objeção de Wright a esse mesmo respeito (95, pp. 89-90), acreditamos que ele acerta ao mostrar os efeitos da teoria das ideias humiana quando empregada contra o cartesianismo. Quanto à passagem citada por ele da seção "Do Ceticismo quanto aos Sentidos" em que ele Hume afirma que não temos como saber se uma conclusão sobre a conexão ou a repugnância de impressões e ideias poderá ser aplicada aos objetos, nossa resposta é bastante simples: Hume não pode querer dizer que essa passagem 
evidentemente, os raciocínios causais instintivos que delas dependem não terão como dar o menor passo no sentido de explicar de onde elas vêm. Assim, não temos como atribuir realidade ao próprio fundamento da crença causal, ao menos se, por realidade, entendermos a garantia de uma existência externa à mente. É nesse contexto que devemos ler a passagem segundo a qual mesmo o cético termina por assentir à existência de corpos: a crença inevitável que nos é imposta pela natureza não implica, de maneira alguma, a existência externa de objetos ${ }^{159}$. No fim das contas, por mais que a crença em objetos externos seja inevitável (e, portanto, também a crença causal que é o resultado necessário dela), não temos como afirmar a partir disso, em termos ontológicos, a existência deles. Isso não quer dizer, é claro, que Hume afirma que objetos externos não existem. Isso simplesmente estaria em desacordo com a teoria do conhecimento que ele desenvolve. O caso parece ser que não podemos afirmar nem negar absolutamente nada com relação à existência de um possível mundo exterior que poderia embasar nossas percepções. Se o filósofo concorda com o vulgo acerca da existência contínua, é por assentir a uma ficção que diz respeito não a objetos externos, mas a nossas próprias percepções, ou não seria tão evidentemente fictícia qualquer atribuição implícita de constância e de independência que devemos aceitar simplesmente porque isso nos é imposto pela natureza ${ }^{160}$.

faz referência a uma diferença entre percepções e um mundo real verdadeiramente existente simplesmente porque a passagem em questão ocorre, justamente, no contexto de uma extensa prova de que não temos como saber se existe algo como um mundo exterior não percebido.

${ }^{159}$ Vale a pena observar que é esse o tipo de crença que, desde os escritos de Norman Kemp Smith, tem sido chamado simplesmente crença natural pelos comentadores de Hume. Comentadores como Strawson e Wright fazem amplo uso desse conceito para tentar justificar suas leituras realistas. A esta altura, já deve estar bastante evidente o modo pelo qual nossa própria interpretação difere daquela apresentada por comentadores como eles.

${ }^{160}$ Kenneth Winkler, em um artigo que, apesar de ser intitulado “The New Hume”, ataca essa concepção, propõe a tese segundo a qual o ceticismo de Hume consistiria em se recusar a afirmar a existência de poderes reais. Isso ocorre porque Winkler aceita que a crença nos tais “poderes reais” tem, para ele, estatuto mais fraco que aquela em objetos externos, os quais ele aceita que têm sua existência praticamente garantida por conta de estarem nossa crença neles ser uma “crença natural”. Isso faz com que seja particularmente importante para Winkler mostrar que a crença causal não tem esse mesmo peso. Acreditamos ter mostrado que, no fim das contas, as duas crenças são, para Hume, igualmente necessárias, de modo que se faz necessário defender o "velho Hume” simplesmente mostrando que 
A primeira Investigação não nos oferece nada muito mais animador no sentido de ver em Hume algo como a afirmação da existência de corpos ou de um realismo causal. A crença causal, como os três princípios de associação, é apresentada como dependente de uma crença em corpos que, como vimos, é pressuposta. Ainda que Hume não elabore esse ponto, parece-nos que ele não teria por que mudar a concepção exposta no Tratado, de modo que essa pressuposição se dá nos termos da crença em objetos externos que o verdadeiro filósofo deve compartilhar com o vulgo, ou seja, a crença absurda e fictícia, mas irresistível, de que as impressões que comumente denominamos objetos têm a constância que suas aparições recorrentes extremamente semelhantes nos fazem crer que elas têm. Desse modo, é impossível que ao falar, na Seção 4, em causas últimas que permanecem escondidas, ou em molas e princípios últimos, Hume esteja se referindo necessariamente a objetos externos que efetivamente existem. O mesmo ocorre com a passagem da Seção 7 em que ele faz referência ao "poder ou a força que

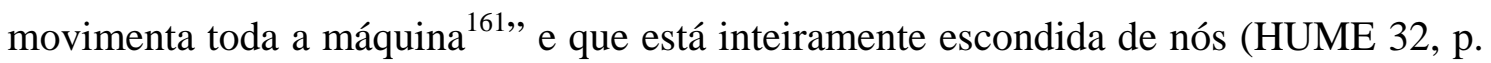
136). As cenas do universo em constante mudança a que nosso filósofo faz referência logo antes dessa passagem, então, são apenas o fluxo de impressões que se nos apresenta ininterruptamente. Não é à toa que, já quase no fim da Seção 7, ele reafirma o que já havia dito sobre a causalidade e oferece duas definições de causa que, complementares, resumem as conclusões que ele atingira na Seção 5: uma relação causal pode ser definida ou como "um objeto seguido por outro, quando todos os

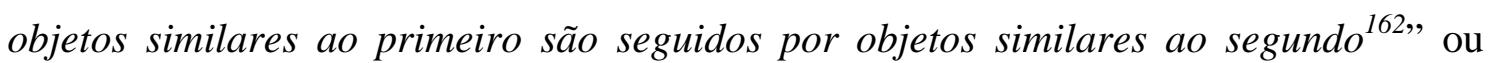
como "um objeto seguido por outro, e cuja aparição sempre transporta o pensamento ao outro ${ }^{163 » " ~(H U M E ~ 32, ~ p . ~ 146) . ~ E s s a s ~ d e f i n i c ̧ o ̃ e s ~ p o d e m ~ c a r r e g a r, ~ c o m o ~ n o s s o ~ f i l o ́ s o f o ~}$ observa, o inconveniente de definir a causa por algo externo a ela, mas, para isso não há

crenças naturais não são uma base sólida para afirmações de existência externa real. Mais ainda, acreditamos que o ceticismo de Hume, no que diz respeito a corpos externos e à crença causal, não consiste em uma recusa de afirmar algo, mas na aceitação da impossibilidade tanto de afirmar quanto de negar o que quer que seja no nível ontológico.

161 “[...] power or force, that actuates the whole machine [...].

162 “[...] an object, followed by another, and where all the objects, similar to the first, are followed by objects similar to the second".

163 "[...] an object followed by another, and whose appearance always conveys the thought to that other" 
remédio, já que não é possível ter qualquer ideia de conexão necessária além dessa. Desse modo, mesmo que recorramos ao texto da primeira Investigação, preferida pelos defensores do "novo Hume", o único tratamento possível da causalidade é enquanto conjunção constante que acarreta uma determinação da mente. Qualquer tentativa de atribuir a ele a posição de que há bons motivos estritamente epistemológicos para se propor sejam afirmações, sejam negações acerca de um mundo exterior realmente existente não parece, para nós, ter bases textuais sólidas.

Por outro lado, parece bastante evidente haver na obra de Hume um naturalismo bem acentuado, já que toda a teoria do conhecimento desenvolvida no Tratado e na primeira Investigação recorre constantemente a princípios naturais inescapáveis. Se eles não estivessem ali, seria impossível conferir à experiência qualquer superioridade, em termos de confiança, sobre os testemunhos mais desvairados. O que não podemos perder de vista é que esse naturalismo é perfeitamente compatível, senão com o ceticismo pirrônico que Hume faz questão de recusar, com um ceticismo de outra forma, que termina por resultar mais em uma delimitação dos domínios próprios do entendimento do que em uma recusa de qualquer raciocínio. Ainda que seja impossível termos uma base ontológica sobre a qual repousa nosso conhecimento das questões de fato, podemos estudá-las porque elas se apoiam sobre um tipo de material que, ainda que não possa se racionalmente justificado, simplesmente não permite que duvidemos seriamente dele. É claro que, na medida em que nossos juízos baseados na experiência não são justificados pela razão em sentido tradicional, sempre serão apenas prováveis, ao menos no sentido lockiano a que Hume em certo momento se refere. Ainda assim, “prováveis”, nesse sentido, não quer dizer que tenhamos menos certeza deles. O que Hume parece tentar estabelecer é que não dependemos da razão, ou de uma base ontológica justificada por ela, para assentirmos a propensões que nos acometem de maneira irresistível por nos terem sido como que impostas pela natureza ${ }^{164}$. Concluímos, então, que, ao menos na filosofia de Hume ceticismo e naturalismo são elementos não apenas compatíveis, mas inseparáveis. O naturalismo é assumido desde

\footnotetext{
${ }^{164}$ E, nesse sentido, parece-nos que se aproxima bastante de Cícero. Talvez, como defende Peter Jones em boa parte do primeiro capítulo de seu Hume's Sentiments, a intenção de Hume tenha sido, ao menos em parte, fornecer fundamentos mais sólidos para a concepção ciceroniana segundo a qual, mesmo sem ter como estabelecer como verdades epistemologicamente irrefutáveis certos conceitos essenciais para a prática, temos bons motivos para assentir a eles.
} 
os princípios do pensamento humiano e, se é verdade que conduzirá a formulações céticas, também é verdade que o salvará das conclusões mais devastadoras que poderiam resultar desse ceticismo. O pirronismo é recusado não apenas por ser inconveniente, mas também porque seria impossível, uma vez aceita a análise humiana de nossas propensões naturais, aceitar sinceramente qualquer coisa parecida com ele. $\mathrm{O}$ que está em jogo, então, não é se existe o mundo sobre o qual julgamos a partir da causalidade, mas permitir que certas crenças sejam mais justificáveis que outras mesmo que não exista uma única entre elas que resista a um exame pautado pela razão demonstrativa tradicional. Uma vez que a natureza oferece esse tipo de justificativa, sobra, ainda, um considerável espaço para o ceticismo, que será imbatível sempre que disser respeito àquilo que se afasta da experiência, já que, nesses casos, ele sempre conseguirá, como já dissemos, destruir irremediavelmente qualquer convicção. Quanto ao próprio terreno daquilo que percebemos ou sentimos todos os dias, ele pode empregar tantos argumentos quanto for possível e, mais do que isso, pode ser que todos os argumentos céticos quanto ao mundo compartilhado por filósofos e homens comuns estejam corretos. O caso é que, nesse tipo de situação, Hume considera que eles não devem fazer a menor diferença.

Esse é mais um ponto em que não acreditamos que há discordância entre o Tratado e a primeira Investigação. As dúvidas expostas nesta última com respeito à causalidade são, é claro, dúvidas céticas, e são dispersas por soluções céticas. Além disso, a verdadeira filosofia é exposta como uma filosofia cética, nos moldes que Hume considera que seriam os da Nova Academia. A única salvação possível, então, só pode vir na forma de propensões naturais a que não podemos resistir, ainda que não as possamos justificar. E a Investigação apresenta, ainda mais do que o Tratado, uma preocupação em distinguir crenças que devem ser consideradas válidas de outras que não merecem qualquer assentimento. Ao final, apenas a natureza garante qualquer conclusão experimental, o que, como no Tratado, aproxima consideravelmente o filósofo do homem comum. A interdependência entre ceticismo e naturalismo é, então, a mesma nos dois escritos. Do mesmo modo, ambos mostram um esforço bastante claro por parte do autor no sentido de conferir à filosofia a "mistura grosseira" que a aproxima do senso comum.

Isso não quer dizer de maneira alguma que Hume considera a filosofia como redutível ao senso comum. O que ele propõe é um pensamento que, admitindo que todo 
o conhecimento que temos do “mundo ao nosso redor” é determinado por um princípio instintivo comum ao vulgo e aos filósofos, possa ser desenvolvido a partir desse princípio. O filósofo deve, então, aceitar-se como um ser social, abraçando a imersão no mundo da conversação tanto como um paliativo para sua tendência a desenvolver hipóteses mirabolantes quanto como uma fonte de experiências que serão por ele avaliadas. Se tudo o que ele pode fazer é "metodizar e corrigir" as reflexões da vida comum, é porque ele traçará as relações verdadeiramente aceitáveis a partir de uma experiência que é comum a todos os homens. Pode parecer menos impactante do que discorrer sobre a origem do universo ou sobre a divindade, mas certamente é o tipo de conhecimento que pareceria apropriado, segundo nosso autor, a qualquer filósofo sensato e, consequentemente, modesto.

\section{A religião como caso}

Isso explica, é claro, porque a experiência religiosa é tratada, ao longo de quase toda a obra de Hume, não do ponto de vista da existência real da divindade, mas ou como um fenômeno simplesmente mental, ou como uma questão de cunho social. O tratamento de problemas religiosos no Tratado, na primeira Investigação e na História natural da religião, como já vimos, diz respeito à origem do fenômeno religioso, ao impacto que ele exerce sobre a sociedade ou sobre o modo como a simples fé se compara a crenças que parecem mais justificáveis. Ora, seria impossível que um autor que não tem como afirmar nem mesmo a existência do mundo exterior se pusesse a discorrer sobre a real existência de Deus ou algo do tipo. Mas a questão é mais complicada. A religião oferece a Hume uma oportunidade privilegiada de mostrar de que modo temas distantes da experiência se tornam completamente intratáveis. É claro que não é apenas isso que está em jogo na filosofia da religião desenvolvida por nosso autor, mas esse é, certamente, um aspecto que podemos levar em consideração. E não podemos nos deixar enganar, a esse respeito, pela “conversão” de Filo ao fim dos Diálogos sobre a religião natural. Como se sabe, em partes anteriores à final, em que ocorre a suposta mudança de posição de Filo, são apresentados vários argumentos contra o argumento do desígnio, sustentado por Cleantes como aquele por meio do qual a religião pode ser racionalmente estabelecida. A analogia entre o universo e uma máquina construída por homens não é vista como mais perfeita que aquela entre o 
universo e um vegetal. E máquina e vegetal estão ambos muito distantes daquilo que entendemos por universo e, portanto, a analogia é destituída de força real tanto em um caso quanto no outro. E ainda que a analogia fosse considerada válida, raciocinar a partir do universo (efeito) para descobrir características da divindade (causa) teria consequências complicadas, para dizer o mínimo. Esse modo de raciocinar não poderia oferecer garantias, por exemplo, de que a criação tenha sido obra de um só deus. Além disso, parece que o universo tem toda sorte de imperfeições, sendo exemplos dos mais gritantes os inúmeros sofrimentos enfrentados pelos seres humanos.

Esses argumentos, bem como uma série de outros que não reproduziremos aqui, não são de maneira alguma refutados antes da suposta conversão de Filo. Podemos presumir, então, que de algum modo essas objeções retêm sua força, continuam válidas. Além disso, não podemos nos esquecer de que a tal conversão ocorre em um momento do diálogo em que a dramaticidade é grande. Demea, que até então havia participado da conversa, vai embora indignado no final da Seção 11, ao perceber que Filo não emprega argumentos céticos para defender o misticismo que ele próprio aceita. O próprio Cleantes não parece confortável com a disposição do amigo em levantar infindáveis paradoxos. Se Filo cede à posição de Cleantes, então, isso se dá no contexto em que, em um diálogo real, isso seria feito, por assim dizer, para acalmar os ânimos.

Pode parecer, é claro, que aproveitamos o tom do texto para forçar uma conclusão que não tem qualquer amparo conceitual. Esse é um problema que pode ser dirimido tanto pelo fato de as objeções contra o argumento do desígnio não serem refutadas quanto pelos próprios termos em que Filo aceita a existência do deus que Cleantes defende:

"Se a totalidade da teologia natural, como algumas pessoas parecem afirmar, se reduzir à proposição simples, ainda que algo ambígua e no mínimo indefinida, de que a causa ou as causas da ordem do universo provavelmente têm alguma analogia remota com a inteligência humana, se essa proposição não for passível de extensão, variação ou explicação mais particular, se ela não fornecer qualquer inferência que afete a vida humana, ou que possa ser fonte de qualquer ação ou omissão, e se a analogia, imperfeita como é, não puder ser levada mais longe do que a inteligência humana, e não puder ser 
transferida, com qualquer aparência de probabilidade, a outras qualidades da mente [...] ${ }^{165,}$. (HUME 39, p. 260)

São essas as condições para que Filo concorde com o argumento do desígnio. Uma leitura bastante casual basta para que concluamos que essa concordância, por mais que seja uma inegável mostra de grande camaradagem, esvazia completamente a divindade, não permitindo que atribuamos a ela o caráter providente dos ocasionalistas nem o caráter de simples artífice que lhe seria atribuído pelos deístas (está claro que esta última posição é a esposada por Cleantes). Só o que Filo reconhece é que as causas da ordem do universo provavelmente têm uma analogia remota com a inteligência humana; nada mais. Isso é tudo que o método experimental (não questionado por Filo, e defendido efetivamente por Cleantes) permite que concluamos no que diz respeito a assuntos religiosos. Se pretendermos concluir mais que isso, incorreremos na forma de falsa filosofia associada à religião que discutimos no capítulo anterior. É nesse quadro geral que interpretamos o movimento em que, ao fazer o que parece ser uma concessão, Filo esvazia qualquer ideia mais significativa da divindade. O modo como Hume discute a religião pode, assim, ser lido, entre outros aspectos, como um alerta sobre o que acontece quando raciocinamos sem qualquer recurso à experiência. É, portanto, um exemplo daquilo que justifica a “inquisição” proposta por Hume ao fim da Investigação sobre o entendimento humano ${ }^{166}$.

\footnotetext{
165 "If the whole of natural Theology, as some People seem to maintain, resolves itself into one simple, tho' somewhat ambiguous, at least undefin'd Proposition, that the Cause or Causes of Order in the Universe probably bear some remote Analogy to human Intelligence: If this Proposition be not capable of Extension, Variation, or more particular Explication: If it affords no Inference that affects human Life, or can be the Source of any Action or Forbearance: And if the Analogy, imperfect as it is, can be carry'd no farther than to the human Intelligence; and cannot be transfer'd, with any Appearance of Probability, to the other Qualities of the Mind [...]”.

${ }^{166}$ Parece interessante observarmos, então, que, no que diz respeito à filosofia humiana da religião, tendemos a concordar, em termos gerais, com interpretações como as de Kemp Smith, Noxon e O’Connor. De qualquer modo, não nos deteremos, aqui, em discutir de maneira mais detalhada a posição religiosa de Hume, já que basta, para os propósitos que temos aqui, estabelecer que, para ele, posições religiosas definitivamente não são um assunto que pode ser discutido pela filosofia em um nível, por assim dizer, ontológico, já que estão demasiadamente afastadas da experiência.
} 
Como vimos, o fato de Hume atribuir à experiência inegável normatividade no que diz respeito a nossos raciocínios sobre o mundo constitui, de maneira inequívoca, uma aproximação entre o filósofo e o homem comum. No capítulo seguinte, veremos que essa aproximação aumentou consideravelmente no decorrer da obra de nosso filósofo e faremos as considerações que restam para que possamos, enfim, concluir de maneira sumária quais são, para ele, as principais características da verdadeira filosofia.

\section{CAPítulo IV}




\section{QUE FILOSOFIA?}

Vimos no capítulo anterior que o modo como Hume estabelece as bases do conhecimento sobre a experiência resulta inequivocamente em uma aproximação com o senso comum. Mais do que isso, o modo como filósofos devem buscar o conhecimento é, no fim das contas, algo como uma correção daquilo que os homens comuns podem, eles mesmos, descobrir em suas vivências. Evidentemente, isso não pressupõe a igualdade da filosofia e do conhecimento do vulgo, ou não haveria qualquer necessidade de correção ou de metodização do saber comum. O que ficou estabelecido é que o ponto de partida do filósofo, bem como o tipo de "razão" que ele empregará em suas investigações, é, também, acessível ao homem comum. A revisão do senso comum realizada pela filosofia é resultado de um procedimento que, a partir de um estudo rigoroso da natureza humana, pode determinar, a partir de conclusões sólidas sobre quais são as relações verdadeiramente efetivas em um mundo que é entendido como um perpétuo fluxo perceptivo, quais as conclusões a que podemos dar nosso assentimento.

A afirmação de que a filosofia é vista por Hume antes de qualquer coisa como o estudo da natureza humana tornou-se há muito tempo um clichê. Esse é um ponto que fica estabelecido desde a "Introdução" do Tratado da natureza humana, obra de estreia de nosso autor, na qual ele afirma que a as infindáveis controvérsias entre os letrados têm sua raiz no fato de, por muito tempo, os pensadores de maneira geral não se terem dado conta de que "a ciência do homem é o único fundamento sólido para as outras ciências ${ }^{167 ”, ~(H U M E ~ 31, ~ p . ~ 4) . ~ E ́ ~ c l a r o ~ q u e ~ n a ̃ o ~ t e m o s, ~ a i ́, ~ e x a t a m e n t e ~ u m a ~ c r i ́ t i c a . ~ D o ~}$ mesmo modo que, na antiga Grécia, houve um intervalo entre as filosofias da natureza pré-socráticas e aquelas que, posteriormente, teriam buscado dar conta de problemas morais ${ }^{168}$, Hume considera que seria de se esperar que algo desse tipo acontecesse na Inglaterra de seu tempo. Assim, não o espanta que tenha havido também um intervalo

\footnotetext{
167 “[...] the science of man is the only solid foundation for the other sciences”.

168 Não devemos nos esquecer de que “moral”, nesse caso, é usado para tudo aquilo que se refere ao estudo do próprio homem, incluindo aí não apenas aquele aspecto em que moral e ética se confundem, mas também o estudo da mente humana, da política, da estética etc.
} 
entre as obras de Bacon e as de pensadores como Locke, Shaftesbury, Mandeville, Butler e Hutcheson, entre outros. E Hume considera que esses pensadores, por terem levado o conhecimento da natureza humana a novos patamares, conferem à Inglaterra uma honra tão grande quanto aqueles que levaram os ingleses à proeminência nos estudos de filosofia natural, já que a ciência do homem, além de ter, para nosso filósofo, importância ainda maior, também estaria em uma situação em que precisa de uma grande reforma. Isso porque seria impossível conhecer a "essência da mente", do mesmo modo que seria impossível conhecer os princípios últimos que estabelecem os poderes pelos quais os corpos interagem. Para Hume, só o que podemos fazer para investigar tanto a natureza humana quanto qualquer outro tema é realizar experimentos exatos e cuidadosos, observando os efeitos particulares que resultam das diferentes circunstâncias e situações em que o ser humano é colocado.

Essa opção desde o início pelo método experimental é, certamente, inspirada pelos trabalhos de Newton, que certamente era visto por Hume como um autor que teria angariado grande respeito para a Inglaterra por meio de suas descobertas. A admiração de nosso filósofo fica evidente, por exemplo, na seguinte passagem do Volume VI da História da Inglaterra:

Com Newton, esta ilha pode se gabar de ter produzido o maior e mais raro gênio que já surgiu para o ornamento e a instrução de nossa espécie. Foi cauteloso ao não assumir quaisquer princípios senão aqueles que estivessem fundados em experimentos, mas resoluto em adotar todos os que estivessem, não importando quão novos ou incomuns. Por conta de sua modéstia, ignorava sua superioridade sobre o resto da humanidade e foi, por isso, menos cauteloso ao acomodar seus raciocínios às apreensões comuns. Foi mais ansioso por merecer a fama do que por adquiri-la ${ }^{169}$. (HUME 40 vol. VI, p. 542)

\footnotetext{
169 "In Newton this island may boast of having produced the greatest and rarest genius that ever arose for the ornament and instruction of the species. Cautious in admitting no principles but such as were founded on experiment; but resolute to adopt every such principle, however new or unusual: From modesty, ignorant of his superiority above the rest of mankind; and thence, less careful to accommodate his reasonings to common apprehensions: More anxious to merit than acquire fame [...]”.
} 
O comentário segundo o qual Newton não teria sido cauteloso ao "acomodar seus raciocínios às apreensões comuns” provavelmente se refere ao fato de ele ter aceitado preceitos religiosos que não poderiam ser provados por suas teorias. Ainda assim, podemos observar que, de maneira geral, os escritos de Newton sobre temas relacionados àquilo que hoje denominamos a física não dependem das afirmações teológicas realizadas por ele e, de maneira geral, esses dois aspectos da obra newtoniana podem ser lidos de maneira consideravelmente independente. Isso não quer dizer, é claro, que o argumento do desígnio, certamente uma das hipóteses em que Hume pode ter visto uma concessão newtoniana às "apreensões comuns", não tenha, por conta disso, merecido as críticas bastante pesadas que são feitas a ele nos Diálogos sobre a religião natural, por exemplo. Mas podemos dizer que Hume teria sido motivado a empreender uma carga tão pesada não exatamente contra o próprio Newton, mas contra o uso que newtonianos com quem ele debateu fizeram desse argumento, certamente empregando-o de modo muito mais amplo e muito menos consistente.

De qualquer modo, é de se esperar que Hume tenha, como tantos em seu tempo, visto no grande sucesso dos experimentos newtonianos algo que certamente o motivaria a empregar o “método experimental nos assuntos morais”, conforme vemos no subtítulo do Tratado. Essa inspiração fica mais evidente, por exemplo, quando encontramos, no tratamento que nosso filósofo realiza dos princípios de associação de ideias, a observação de que a atração que vemos no mundo mental tem efeitos tão extraordinários quanto aquela que observamos no mundo natural (HUME 31, p. 14), o que certamente é uma referência à lei da gravitação descoberta por Newton.

Isso não quer dizer, é claro, que Hume, ainda que ele seja bastante conhecido por ter buscado se tornar o "Newton da Moral”, tenha pretendido realizar um tratamento estritamente newtoniano da natureza humana. Uma evidência nesse sentido pode ser encontrada, por exemplo, em uma carta à Sra. Dysart, em que nosso filósofo, em tom bem humorado, afirma que, ainda que Newton tenha sido capaz de fazer uma série de descobertas importantes, por exemplo, em relação ao peso dos planetas, "não tinha álgebra suficiente para reduzir as partes amigáveis de nossa espécie a uma equação justa, de modo que as mulheres são "os únicos corpos celestes cuja órbita é, ainda, 
incerta $^{170, "}$ (HUME 38, v. I, p. 159). É claro que essa passagem é uma tirada espirituosa que Hume faz com uma amiga (e um chiste que talvez tenha incomodado algumas leitoras feministas do filósofo escocês) e, sozinha, ela não bastaria para afirmarmos que ele consideraria impossível um tratamento completamente newtoniano das ciências morais. Entretanto, essa não é a única evidência de que dispomos para sustentar essa afirmação. Nosso filósofo, no curso de sua vida universitária, provavelmente não assistiu os cursos que o habilitariam a compreender os aspectos matemáticos mais complicados dos escritos de Newton ${ }^{171}$. Isso não impede, é claro, que ele certamente tenha prestado atenção à Questão 31 do Livro III da Óptica, em que Newton descarta hipóteses que não sejam extraídas de experimentos ou verdades certas, além de propor, nas ciências naturais, a precedência do método indutivo. Podemos estabelecer, assim, que, ainda que a influência de Newton sobre Hume possa ter sido muitas vezes exagerada por comentadores, é inegável que nosso filósofo foi inspirado de maneira algo significativa pela "maneira de pensar" newtoniana, ainda que talvez tenha se distanciado de um método estritamente similar ao do físico inglês por estar mais interessado em estabelecer uma obra de cunho humanístico, sendo esse um aspecto que se tornou cada vez mais proeminente nos escritos humianos ${ }^{172}$. De qualquer maneira, não podemos negar que Newton foi uma inspiração importante ao menos ao fazer com que Hume visse que poderia proceder segundo um método que recorresse à experiência

170 “[...] had not Algebra enough to reduce that amiable Part of our species to a just equation: and they are the only heavenly bodies, whose orbits are yet uncertain”.

${ }^{171}$ Esse ponto é muito bem estabelecido por Peter Jones a partir de registros da vida universitária de Hume que permitem que afirmemos que a familiaridade de nosso autor com a filosofia newtoniana teria se dado por meio de alguns compêndios e da leitura de excertos da obra de Newton mais acessíveis a um leitor versado mais nas obras clássicas e naquilo que chamaríamos "humanidades” do que com as ciências que, hoje, denominaríamos ciências exatas. Hume estaria mais familiarizado, portanto, com trechos como os Prefácios, as Definições e os Axiomas dos Principia, bem como o Escólio Geral e as Regras de Raciocínio do Livro III (que parecem ter sido uma grande inspiração para as "regras para se julgar sobre causas e efeitos” da Seção 15 da Parte 3 do Livro 1 do Tratado). Além disso, é provável que Hume tenha tido contato com as Questões anexadas ao Livro III da Óptica. Cf. JONES 45, pp. 11-3.

172 Seguimos, quanto a isso, a posição adotada por Peter Jones no Capítulo Um de seu Hume’s Sentiments. Nossa intenção não é, aqui, fazer, como Jones, uma leitura que aproxime Hume do humanismo ciceroniano e encontrar aí uma resposta para a questão de quanto nosso filósofo se aproxima de Newton. Só o que pretendemos é apontar uma inspiração que certamente foi importante importante para que Hume escolhesse aquele que considerou o melhor modo de proceder. 
e, mais do que isso, também pode ter sido uma influência determinante para que nosso autor se preocupasse em instaurar uma epistemologia que, partindo de um método que se pauta pela experiência, termina por justificá-lo, mostrando que o único conhecimento possível que temos do mundo provém dela.

Fizemos, no capítulo anterior, algumas conclusões a que Hume é levado por esse método que escolheu. Observamos que ele é levado a instaurar uma forma de conhecer o mundo pautada por uma razão que pode ser vista, no fim das contas, como uma forma específica da razão animal e, mais do que isso, vimos que isso transforma o conhecimento em uma crença que pode ser considerada como uma propensão. Isso foi importante para que pudéssemos apresentar uma leitura segundo a qual a filosofia humiana se aproximava, em larga medida, do senso comum. E se é assim, faz sentido observarmos em que termos se dá essa aproximação e, também, se o modo como Hume a concebia sofreu alguma alteração significativa ao longo de sua obra ${ }^{173}$. É de aspectos como esses que trataremos a seguir.

Em primeiro lugar, observamos que não é por ter proposto uma filosofia mais próxima do senso comum que Hume pretendeu, desde o início, atingir efetivamente aqueles que estivessem distantes do mundo acadêmico. Ainda que o "Advertisement" que abre o Tratado da natureza humana termine com a afirmação de que o julgamento do público será considerado pelo autor como a melhor das instruções sobre os méritos de seu trabalho, a "Introdução" deixa bastante claro que o "público" que nosso filósofo tem em vista à época não poderia ser mais restrito. Depois de afirmar que não teria nada contra aqueles que buscam elogiar seus próprios trabalhos criticando os de outros pensadores caso se limitassem a reconhecer a ignorância em que a humanidade se encontra em vários pontos importantes, Hume faz a seguinte afirmação:

Nem é preciso um conhecimento tão profundo para descobrir a condição presentemente imperfeita das ciências, mas até mesmo a ralé do lado de fora pode julgar, pelo barulho e pelo clamor que

\footnotetext{
${ }^{173}$ Trata-se, nesse sentido, de observar de que modo, então, o método experimental adotado desde o início por Hume o levou conceber obras de caráter cada vez mais humanístico.
} 
escuta, que as coisas não vão bem do lado de dentro ${ }^{174}$. (HUME 31, p. 3)

A mensagem é bastante clara. Temos aí uma cisão bastante óbvia entre aquilo que, anos mais tarde, em “Of Essay Writing”, Hume chamaria o mundo letrado e o mundo da conversação, e nosso filósofo escreve, sem a menor dúvida, para o primeiro. Se a "ralé do lado de fora” escuta apenas ruídos e clamores, é porque os letrados não conseguem resolver suas controvérsias sobre o que quer que seja. As disputas se multiplicam cada vez mais e, no fim das contas, sai vitorioso não aquele que for o melhor raciocinador, mas aquele que for mais eloqüente. Desse modo, é como se a vitória fosse ganha "não pelos homens de armas, que empunham a lança e a espada, mas pelos corneteiros, percussionistas e músicos do exército ${ }^{175, " ~(H U M E ~ 31, ~ p . ~ 3) . ~ O ~}$ resultado é uma grande desconfiança com relação a qualquer raciocínio metafísico, entendido, aqui, não como um ramo particular do conhecimento, mas como qualquer argumento minimamente abstruso. "Desperciçamos com tanta freqüência nosso trabalho nessas pesquisas", diz Hume, "que comumente as rejeitamos sem hesitação, e resolvemos que, se devemos ser para sempre presa de erros e ilusões, eles deverão ao menos ser naturais e divertidos $^{176,}$ (HUME 31, p. 3). Ocorre, porém, que isso só se justificaria pela indolência, aliada ao ceticismo mais determinado. Afinal, se a verdade estiver ao alcance da inteligência humana, é certo que não será fácil encontrá-la. Pelo contrário, ela deverá se encontrar em algum ponto bastante abstruso e difícil de se atingir, de modo que seria presunção acreditarmos que a verdade aparecerá para nós sem qualquer esforço. O preconceito esposado pelos homens comuns parece, então, apontar para a direção errada, já que deveríamos precisamente desconfiar dos raciocínios que aparentam ser demasiadamente fáceis (HUME 31, pp. 3-4). Depois

\footnotetext{
174 "Nor is there requir'd such profound knowledge to discover he present imperfect condition of the sciences, but even the rabble without doors may judge from the noise and clamour, which they hear, that all goes not well within”.

175 "[...] not gain'd by the men at arms, Who manage the pike and the sword; but by the trumpeters, drummers, and musicians of the army".

176 "We have so often lost our labour in such researches, that we commonly reject them without hesitation, and resolve, if we must for ever be a prey to errors and delusions, that they shall at least be natural and entertaining”.
} 
dessas considerações é que nosso filósofo inicia suas considerações segundo as quais o estudo da natureza humana é colocado como a base para todos os outros.

Vemos, então, que a "Introdução" do Tratado já antecipa alguns aspectos que retornarão na "Conclusão" do Livro 1. O filósofo é apresentado como alguém que deve admitir sua ignorância em vários assuntos considerados importantes e, mais do que isso, deve abrir mão de descobrir "os princípios últimos da alma”. Deve limitar-se, portanto, a saber aquilo que é possível saber, e satisfazer-se, de maneira geral, com sua ignorância, percebendo que "não podemos dar razão alguma para nossos princípios mais gerais e mais refinados, além de nossa experiência de sua realidade ${ }^{177, " ~(H U M E ~ 31, ~ p . ~}$ 5), ou seja, deve contentar-se, após seus longos estudos, em saber, no que diz respeito a certos temas, aquilo que o vulgo sabe sem pesquisa alguma. Isso, aliado à rejeição de um ceticismo extremado, que, como na “Conclusão” do Livro 1, aparece aliado à indolência, basta para que rejeitemos a ideia de que Hume seria, por assim dizer, um cético total. A proposta é, desde o início, delimitar aquilo que podemos saber, ainda que, no fim das contas, não haja como fundamentar de maneira racional o “conhecimento" que teremos desses fenômenos. Assim, desde o início do Tratado já estaria traçada certa aproximação do filósofo com o homem comum, na medida em que nosso autor vaticina, já na "Introdução”, que essas duas “classes” ficarão, no fim das contas, circunscritas ao mesmo escopo no que diz respeito àquilo que é possível conhecer.

\section{O pintor e o anatomista}

Por outro lado, como vimos, não parece que Hume escreve para o homem comum. Ao falar em uma "ralé do lado de fora", ele parece dirigir-se a seus colegas letrados. E não pretende apenas que prestem atenção a uma teoria do conhecimento que critique os termos usuais em que o conhecimento é compreendido, mas conclama-os a recuperar seu prestígio e o respeito do homem comum, o que denota que a vida comum tem, desde o início, certa preponderância sobre as especulações frias dos letrados. O homem comum, em outras palavras, ainda que seja apresentado como a turba, a ralé,

177177 “[...] we can give no reason for our most general and most refin’d principles, beside our experience of their reality". 
teria sido capaz de ver através da mera retórica e perceber que os eruditos os enganavam, limitando-se a ocultar sua ignorância. E isso teria ocorrido não porque os eruditos teriam se mostrado incapazes de chegar a verdades últimas, mas porque simplesmente teriam mantido, por muito tempo, discussões que, por estarem distantes da experiência, seriam completamente desprovidas de qualquer sentido.

Tudo isso não muda o fato de que o Tratado não é, ele mesmo, um escrito que tem em vista atingir o homem comum. Se Hume faz algo como uma chamada para a batalha, propondo que o próprio “exército” busque diretamente a natureza humana, que seria algo como capital do conhecimento, em oposição aos vilarejos de pouca importância que teriam sido conquistados até então (HUME 31, p. 4), está claro que os “homens de armas” em questão são aqueles que compõem o público erudito. Não temos como duvidar de que é a eles que nosso autor se dirige na "Introdução" e, evidentemente, também ao longo de todo o restante do Tratado.

Isso é confirmado ao fim do Livro 1, em que temos a afirmação, já mencionada no capítulo anterior, de que Hume não pretende tornar filósofos os homens comuns, mas perseguir justamente o objetivo contrário, ou seja, impingir aos pensadores “incandescentes" a "mistura terrena grosseira" de que tanto falamos anteriormente. Além disso, parece que é nessa nota que nosso filósofo conduz todo o seu Tratado da natureza humana. A “Conclusão” do Livro 3, seção que encerra o primeiro escrito de Hume, apresenta evidências bastante claras disso. Em seus últimos parágrafos são feitas algumas conclusões sobre a relação entre virtude e felicidade, e parece que ela é das mais estreitas. Depois de afirmar a moralidade como algo que, apesar de ser uma invenção, é indispensável desde a própria formação da sociedade, o texto menciona o “acesso de alacridade” que sentimos ao empreender pesquisas que não apenas resultam em benefícios diretos para aqueles que as empreendem, mas também dão a eles "um novo brilho aos olhos da humanidade”178. Além disso, parece que nem mesmo todas as

\footnotetext{
${ }^{178}$ Aqui, devemos ter em mente que Hume não se refere apenas à reputação que um homem pode ganhar por conta de seu conhecimento ou de suas virtudes. O "novo brilho" de que ele fala tem a ver, também, com o fato de ele colocar o fundamento da moralidade em um sentimento que, de maneira bastante simplificada, poderíamos dizer que acomete o espectador de ações que revelam um caráter virtuoso. Fica plenamente estabelecido, então, que essa passagem indica não apenas que nos sentimos bem ao sermos admirados pelos outros, mas a própria relação entre virtude e felicidade. Não convém que exponhamos de maneira extensa, neste ponto, todo o modo como essa relação é constituída ao longo da teoria moral
} 
vantagens podem compensar a menor brecha referente às virtudes sociais, já que esse tipo de atitude não apenas provoca a censura alheia, mas também é bastante prejudicial à paz de espírito. Entretanto, Hume se abstém de ir adiante nesse tópico e, se o faz, é por considerar que algo desse tipo exigiria um trabalho de natureza bastante diferente da de seu Tratado. A metáfora que ele emprega para se explicar nesse ponto aparecerá mais de uma vez em sua obra, de modo que parece interessante que a reproduzamos aqui em sua íntegra:

O anatomista nunca deve emular o pintor, nem pretender, em suas dissecações e em seus retratos precisos das partes mais minúsculas do corpo humano, dar a suas figuras qualquer atitude ou expressão graciosa ou atraente. Há algo de hediondo, ou ao menos de mesquinho nas visões das coisas que ele apresenta, e é necessário que os objetos sejam colocados a uma distância maior, e estejam mais cobertos em relação à vista, para que se façam atraentes ao olho e à imaginação. Um anatomista, entretanto, é admiravelmente apropriado para dar conselhos a um pintor, e é até mesmo impraticável atingir a excelência na arte deste último sem a assistência do primeiro ${ }^{179}$. (HUME 31, p. 395)

Essa metáfora certamente está entre as mais conhecidas dentre as escritas por Hume, ainda que a maioria dos leitores contemporâneos de sua obra pareça ter se familiarizado com ela devido à Seção 1 da primeira Investigação, na qual, como veremos, ela é empregada já com intenções bastante diferentes. De qualquer maneira, a relação entre a filosofia pretendida por Hume e o homem comum que essa metáfora expressa no Tratado é bastante clara. É possível que haja trabalhos filosóficos que

humiana, já que pretendemos apenas contextualizar a passagem de que estamos tratando, a qual nos dará a oportunidade de fazer mais algumas considerações sobre o modo como a relação entre filosofia e senso comum é concebida no Tratado.

179 "The anatomist ought never to emulate the painter; nor in his accurate dissections and portraitures of the smaller parts of the human body, pretend to give his figures any graceful and engaging attitude or expression. There is even something hideous, or at least minute in the views of things, which he presents; and 'tis necessary the objects shou'd be set more at a distance, and be more cover'd up from sight, to make them engaging to the eye and imagination. An anatomist, however, is admirably fitted to give advice to a painter; and 'tis even impracticable to excel in the latter art, without the assistance of the former. 
pretendem mostrar a todos de que modo o homem comum pode se beneficiar de reflexões sobre a virtude e os vários modos como ela é proveitosa, mas não é o caso do primeiro trabalho de Hume. Como vimos, a "Introdução" da obra, bem como a “Conclusão” de seu Livro 1, parecem deixar bastante claro que, então, era aos eruditos que nosso autor se dirigia. Assim, ainda que a filosofia humiana se pretenda útil já desde o Tratado, não podemos vê-lo como uma obra para a ilustração de um suposto grande público. O que o filósofo pretendia, ao escrever seu livro de estréia, era que as “especulações mais abstratas referentes à natureza humana, não importando quão frias ou tediosas ${ }^{180,}$ (HUME 31, p. 395), se tornassem úteis no âmbito da prática por meio da instrução não do leitor comum, mas daqueles que praticassem aquilo que, na Seção 1 da primeira Investigação, Hume viria a chamar, como veremos adiante, “filosofia fácil”. No Tratado, fica claro que nosso filósofo pretendeu escrever como aquilo que ele denominou, de maneira metafórica, um anatomista. Em outras palavras, o objetivo do Tratado não é incitar os homens comuns à prática da virtude ou de paixões mais reguladas, mas criar uma ciência que permita a descoberta do modo como a mente funciona que poderá permitir que os “pintores”, por sua vez, tratem de mostrar ao público de que modo proceder. É claro que não é pouco quando pensamos em Hume como um filósofo que se dedicou, em boa parte de sua carreira, ao estudo de regras que pudessem determinar questões morais, estéticas e políticas. E se vemos que ele foi um autor que pretendeu fornecer fundamentos que estivessem de acordo com princípios baseados no mesmo ponto de partida que o senso comum, percebemos que é certo que ele, desde o princípio, concebeu sua filosofia como algo que poderia ter algum tipo de impacto, ainda que indireto, sobre o leitor comum. Ainda assim, somo obrigados a reconhecer que Hume ainda pretendia que esse impacto fosse, como dissemos, indireto. O maior motivo para isso aparece em uma carta a Francis Hutcheson em que nosso filósofo afirma que não consegue “conceber facilmente esses dois caracteres [o pintor e

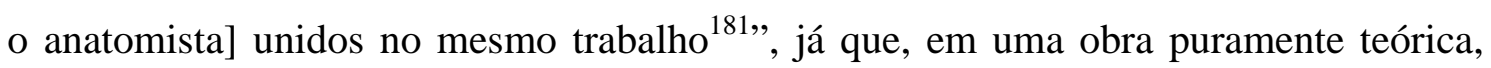

\footnotetext{
180 “[...]the most abstract speculations concerning human nature, however cold and unentertaining [...]”

181 "[...] conceive these two Characters united in the same Work”.
} 
quaisquer sentimentos mais vívidos ganhariam ares de declamação, o que prejudicaria o efeito final da obra ${ }^{182}$ (HUME 38, v. 1 p. 33).

Não há dúvidas, então, de que Hume não se considerava, ao escrever o Tratado, o tipo de autor que poderia ser absorvido pelo grande público. Nesse sentido, a primeira obra de nosso filósofo certamente divergiria dos escritos de um Addison, por exemplo. A situação era certamente bastante diferente quando Hume escreveu os primeiros de seus Ensaios morais e políticos, já que “Of Essay Writing”, a que já nos referimos, foi publicado já na edição de 1742, ainda que depois tenha sido removido pelo autor ${ }^{183}$. Nesse texto, participar do mundo da conversação é, como vimos, o único remédio para o filósofo que pretende evitar os enganos retumbantes que ocorrem quando permitimos que a imaginação exagere em seus devaneios. Por outro lado, o homem comum, de acordo com esse ensaio, terá uma existência bastante tediosa e embrutecida sem recorrer ao menos aos princípios mais elementares da filosofia. Assim, não parece exatamente espantoso que a metáfora do pintor e do anatomista seja empregada, na Investigação sobre o entendimento humano (publicada pela primeira vez em 1748), com um objetivo bastante diferente daquele que originalmente lhe fora conferido.

Quando nos voltamos para o modo como Hume trata a questão da diferença entre o pintor e o anatomista na Seção 1 da primeira Investigação, a primeira coisa que salta aos olhos é o fato de nosso autor dedicar a esse ponto uma atenção muito maior do que aquela que anteriormente lhe havia concedido. A metáfora de que vimos tratando aparece, ao longo desse texto, atrelada a um tratamento relativamente detalhado das diferenças entre duas espécies de filosofia, moral, entendida, ao longo de toda a Seção 1, como a ciência da natureza humana. A primeira dessas duas formas de filosofar, que podemos entender como dois modos de ver o próprio homem, considera-o

\footnotetext{
${ }^{182}$ No original, Hume afirma que tais declamações, em um trabalho desse tipo, seriam "contrárias ao bom gosto". Em outras palavras, estaria preocupado com certas regras de composição. A forma "Tratado" deveria ser considerada, portanto, como um estilo literário em que não cabe qualquer sentimentalismo. Isso poderá se mostrar interessante posteriormente, quando discutirmos de que modo a decisão, por parte de nosso filósofo, de empregar formas diferentes em suas publicações posteriores pode refletir possíveis mudanças na maneira como ele concebia a relação entre o filósofo e o homem comum.

${ }^{183}$ Evidentemente, não tivemos acesso à própria edição de 1742. Devemos essa observação a uma nota de Eugene Miller em sua edição dos Essays moral, political and literary. Cf. HUME 37, p. 533.
} 
principalmente como nascido para a ação, e como um ser influenciado por questões referentes ao gosto e ao sentimento. Essa forma de filosofar pressupõe que o homem persegue um objeto e evita outro dependendo do valor que eles parecem ter, da maneira como eles se lhe apresentam. Portanto, é natural que uma tal filosofia se disponha a pintar a virtude com as cores mais vívidas e que trate de seu tema de maneira tão fácil quanto for possível, já que desse modo é possível agradar a imaginação e cativar as afecções. Para Hume, uma filosofia desse tipo nos seduz para a prática da virtude ao nos mostrar a glória e a felicidade, e faz com que sintamos a diferença entre vício e virtude. É assim, regulando nossos sentimentos, que ela pretende atingir seu objetivo de fazer com que amemos a probidade e a verdadeira honra (HUME 32, p. 87).

A segunda espécie de filosofia é aquela que, em oposição à primeira, considera o homem mais como um ser racional do que como um ser ativo. Procura, portanto, formar o seu entendimento. O cultivo das maneiras fica, para essa forma de filosofia, em segundo plano. A própria natureza humana é vista por ela como um objeto para suas especulações, de modo que é bastante natural que ela seja esmiuçada da maneira mais completa possível. O que este segundo tipo de filosofia procura é descobrir os princípios responsáveis por nosso entendimento, por nossos sentimentos, por nossos juízos morais, por nossas ações. Os adeptos desse modo de filosofar, diz Hume, consideram imperdoável que não tenham sido fixados, ainda, os fundamentos da moral, do raciocínio e da crítica, já que, se é assim, a filosofia deve falar sobre verdade e falsidade, vício e virtude, beleza e deformidade sem ter descoberto, ainda, o fundamento dessas coisas todas. Essa filosofia, para Hume, parte de exemplos particulares para chegar a princípios mais gerais, sem se satisfazer até que tenha alcançado os princípios originais que são o grande alvo da curiosidade dos homens. E ainda que essa filosofia possa parecer completamente ininteligível para os homens comuns, aqueles que a praticam certamente procuram a aprovação dos letrados, e crêem que o sacrifício de toda uma vida é recompensado de maneira mais do que apropriada pela descoberta de certas verdades escondidas que podem contribuir para a instrução da posteridade (HUME 32, p. 88).

Não é difícil reconhecer na descrição da filosofia que "considera os homens como seres racionais” mais do que como ativos e exige o sacrifício de toda uma vida 
aquela que Hume havia dito, no Tratado, ser a sua própria ${ }^{184}$. Ainda que não tenhamos feito aqui uma análise detalhada de todo o trabalho inicial de Hume (o que seria simplesmente impraticável), podemos tecer algumas considerações a esse respeito. Ora, mesmo que o autor não tivesse se referido, ao fim do Tratado, a seu próprio modo de filosofar, nem escrito a Hutcheson para contar sobre suas pretensões, certamente seria possível, a partir do próprio texto, obter algumas informações. Em primeiro lugar, temos o fato bastante óbvio de a teoria humiana do conhecimento ser desenvolvida a partir de observações de casos particulares para conclusões gerais. É claro que não exatamente experimentos ao longo do Livro 1 do Tratado, mas nosso filósofo parte, sem a menor dúvida, daquilo que pode observar. Se fala em impressões e em idéias, além de descrever os mecanismos pelos quais estas últimas se associam, é sempre do modo como parece que elas se apresentam a ele. No Livro 2, parece que as coisas se dão do mesmo modo, havendo, inclusive, uma seção intitulada "Experimentos para confirmar esse sistema” (2.2.2). É claro que se trata, aí, de experimentos de pensamento, mas isso não chega a ser um problema. Não podemos esquecer, por exemplo, dos experimentos de pensamento empregados por Galileu e, além disso, não podemos nos esquecer de que, como Hume avisa ao fim da "Introdução" do Tratado, não é possível simplesmente por a natureza humana no laboratório, já que isso interferiria na ordem das coisas e inviabilizaria qualquer conclusão válida. Assim, é bastante natural que, ao investigar a natureza humana, devamos “extrair nossos experimentos, nessa ciência, de uma observação cuidadosa da vida humana, e tomá-los tais como eles aparecem no curso comum do mundo ${ }^{185}$ " (HUME 31, p. 6). No Livro 3, por fim, Hume nos apresenta, de maneira bastante detalhada, o modo como os princípios descritos nos livros anteriores, aliados a fatos particulares, contribuem para o desenvolvimento da moralidade. É interessante observarmos, aqui, o modo como nosso filósofo constroi sua

\footnotetext{
${ }^{184}$ Pode parecer exagero falar em uma filosofia que exige o sacrifício de toda uma vida, mas, no caso de Hume, não podemos dizer que é exatamente esse o caso. Além das considerações sobre a melancolia presentes na "Conclusão" do Livro 1 do Tratado, devemos levar em conta uma carta com destinatário indefinido, que pode ter sido escrita com o propósito de ser enviada ou a Cheyne (como é mais usualmente aceito) ou a Arbutnoth (hipótese defendida por Ernest Mossner), na qual Hume discorre longamente sobre as várias aflições de que padece, todas elas atribuídas por nosso autor à "doença dos letrados”. Cf. HUME 38, pp. 12-18.

185 “[...] glean up our experiments in this science from a cautious observation of human life, and take them as they appear in the common course of the world [...]".
} 
ciência. O que temos é justamente o procedimento que podemos observar na segunda das espécies de filosofia que ele descreve na Seção 1 da primeira Investigação. É claro que a "Conclusão” do Livro 1 do Tratado nos mostra um filósofo que já superou sua melancolia depois de ser salvo pela natureza, e esse é um tema que é retomado na Seção 1 da Investigação sobre o entendimento humano (retornaremos a ele em breve), mas parece que, de maneira geral, ao se declarar um anatomista ao fim do Tratado, Hume mostra que, ao menos no tocante aos procedimentos que escolhe para conduzir sua ciência da natureza humana, ele se alinhara, em sua primeira obra, aos filósofos da “segunda espécie”. Voltemos, agora, ao texto da Seção1 da primeira Investigação.

Depois de definir as duas espécies de filosofia, Hume passa a expor as vantagens e as desvantagens de cada uma delas. O “primeiro round” é vencido pela filosofia “fácil e óbvia”, que tem sobre aquela "precisa e abstrusa” a vantagem de penetrar mais na vida comum, moldando o coração e as afecções. Desse modo, ela pode reformar a conduta dos homens e aproximá-los dos modelos perfeitos que descreve. A filosofia abstrusa, por sua vez, depende de uma disposição da mente que é bem distante dos negócios e da ação e, portanto, desaparece quando o filósofo "sai das sombras e vem para o dia aberto”. Seus princípios, portanto, não retêm qualquer influência sobre nossa conduta, já que, assim que abandonamos nosso gabinete, eles simplesmente perdem sua força. Quando isso acontece, “Os sentimentos de nosso coração, a agitação de nossas paixões, a veemência de nossas afeç̧ões dissipam todas as suas conclusões e reduzem o filósofo mais profundo a um mero plebeu ${ }^{186 ”}$ (HUME 32, p. 88).

É por isso que a filosofia fácil, além de ter a preferência da maior parte dos homens, tem a fama mais duradoura e, além disso, mais justa, enquanto os pensadores abstratos atingem apenas uma reputação momentânea, derivada apenas do capricho e da ignorância de suas próprias épocas. Para Hume, é bastante fácil que um filósofo abstruso cometa um erro, ao qual sempre se seguirão, em consequência, vários outros. $\mathrm{O}$ resultado final é que um pensador como esse frequentemente terminará por aderir aos princípios mais absurdos apenas porque parecem distantes das opiniões populares. $\mathrm{O}$ filósofo fácil, por outro lado, pretende apenas apresentar o senso comum em cores mais belas e, se incorrer em qualquer erro, não o aceitará por muito tempo, já que terminará

\footnotetext{
186 "The feelings of our heart, the agitation of our passions, the vehemence of our affections, dissipate all its conclusions, and reduce the profound philosopher to a mere plebeian”.
} 
por recorrer ao senso comum e, com isso, retornará ao caminho certo. Esse é, para Hume, o motivo pelo qual Cícero é famoso ainda no século XVIII enquanto Aristóteles já havia perdido, então, boa parte de sua fama ${ }^{187}$. Essa é, também, a explicação dos motivos pelos quais La Bruyère conquistou reputação considerável além-mar, enquanto Malebranche era famoso apenas em seu próprio país e em sua própria época ${ }^{188}$. Por fim, isso também explica por que Addison talvez ainda seja lido com prazer quando Locke estiver completamente esquecido ${ }^{189}$.

Um dos motivos pelos quais a filosofia fácil consegue sua grande popularidade é que o filósofo, ao menos em sua imagem mais caricatural, é comumente considerado um caráter pouco aceitável, alguém que não contribui para a felicidade ou o prazer da humanidade. Ocorre, porém, que o completo ignorante está em situação ainda pior, pois vive em uma época em que as ciências florescem e, portanto, nada é mais natural do que ele obter apenas desprezo. Parece, então, que o caráter ideal seria algo entre esses dois extremos, capaz de reter um gosto pelos livros, pela companhia e pelos negócios. Esse caráter seria capaz de manter na conversação a delicadeza que surge com as belles lettres e, nos negócios, a precisão e a probidade que são características de uma filosofia justa. Ora, nada mais eficiente, no sentido de impingir esse caráter, que a filosofia fácil, a qual não se afasta muito da vida comum, não requer grande aplicação para ser compreendida e, no fim das contas, "devolve o estudante à humanidade cheio de

\footnotetext{
${ }^{187}$ Essa é uma consideração que tem certa graça quando nos lembramos que Hume deve boa parte de sua teoria moral a Hutcheson, que, por sua vez, deve muito de sua teoria moral a Aristóteles, citado frequentemente em suas obras.

${ }^{188}$ Essa observação também se torna bastante curiosa quando lembramos quanto a epistemologia humiana deve aos trabalhos de Malebranche.

189 Esse último comentário de Hume sobre a reputação a ser adquirida por este ou aquele autor é particularmente curioso simplesmente por ter-se revelado um retumbante erro de "futurologia”. De qualquer modo, não podemos nos esquecer que essas previsões de Hume são baseadas em um cenário em que havia um grande público leitor interessado em certa concepção de filosofia que, bem no sentido da “filosofia fácil” descrita por Hume, procurava formar as virtudes e as maneiras dos homens. Talvez nosso autor tenha errado em suas previsões não por estar enganado acerca do caráter dos autores que mencionou, mas por não ter previsto a redução gigantesca do público que ele próprio passou a visar depois do Tratado. Posteriormente, faremos algumas breves considerações sobre que público era esse.
} 
sentimentos nobres e de preceitos sábios, aplicáveis a todas as exigências da vida humana ${ }^{190, " ~(H U M E ~ 32, ~ p . ~ 89) . ~}$

No fim das contas, parece que o homem pode ser visto tanto como um ser racional quanto como um ser social. E ocorre que, do mesmo modo como os limites de seu entendimento são bastante estreitos e, por conta disso, as suas conquistas intelectuais não podem ser muito vastas nem muito seguras, ele não é capaz de aproveitar as boas companhias o tempo todo, seja porque elas não estão disponíveis sempre ou porque é impossível preservar indefinidamente o gosto por elas. Outro aspecto do homem é que ele é também um ser ativo e, portanto, é preciso que se envolva também nos negócios (a isso ele também é compelido por suas necessidades). Também aí as coisas não são tão simples, já que a mente precisa, ocasionalmente, relaxar. Assim, parece que a forma de vida mais aconselhada pela natureza seria mista; não é recomendável que o homem se dedique exclusivamente a uma das características que acabamos de mencionar. Podemos nos dedicar à ciência, mas devemos mantê-la humana e garantir que ela se refira diretamente à sociedade. Qualquer raciocínio abstruso, diz Hume, será punido pela natureza com uma melancolia preocupada, por incertezas infindáveis e por uma recepção bastante fria dos trabalhos de quem se dedicar a esse tipo de reflexão. É daí que vem o célebre conselho que a natureza oferece a Hume na Seção 1 da primeira Investigação: “Seja filósofo, mas, em meio a toda a sua

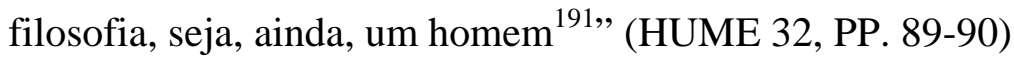

Parece quase desnecessário afirmar que existem grandes semelhanças entre aquilo que Hume defende nesse ponto da primeira Investigação e certas teses defendidas na "Conclusão" do Livro 1 do Tratado. É verdade que, no texto de juventude, a melancolia era causada pelo ceticismo excessivo a que o filósofo se via levado por seus estudos. De qualquer maneira, ao vinculá-la, aqui, ao pensamento abstruso, o raciocínio não é muito diferente. Não podemos perder de vista que Hume insiste, ao longo de toda a Seção 1 da Investigação sobre o entendimento humano, no vínculo entre filosofia fácil e experiência. Podemos concluir, então, que, de maneira geral, os filósofos abstrusos cometem o erro de se distanciar do mundo percebido, o que

190 “[...] send back the student among mankind full of noble sentiments and wise precepts, applicable to every exigence of human life".

191 "Be a philosopher; but, amidst all your philosophy, be still a man”. 
os levaria a não ter garantia alguma sobre o que quer que seja. Desse modo, não têm como evitar incorrer na melancolia e no delírio que haviam sido mencionados na “Conclusão" do primeiro livro do Tratado da natureza humana. Outro aspecto importante é que no início da primeira Investigação, como na seção que encerra o Livro 1 do Tratado, recomenda-se ao filósofo que ele tenha uma vida ativa e que não abra mão da vida social. E também como já acontecia no Tratado, é a própria natureza que impõe ao filósofo que ele proceda desse modo se não quiser ser acometido pela “doença dos letrados”. Ao menos nesse aspecto, podemos dizer com certa segurança que Hume não alterou, então, sua concepção de filosofia.

Nosso filósofo continua a Seção 1 da Investigação sobre o entendimento humano afirmando que, se a maior parte dos homens, mesmo preferindo a filosofia fácil, não rejeitasse por completo os raciocínios abstrusos, ele não poderia se queixar. Porém, não é assim que as coisas se dão. Frequentemente observamos uma rejeição, por parte do leitor comum, “daquilo que é comumente chamado metafísica ${ }^{192, ”, ~ r e f e r i n d o-s e ~}$ não apenas a textos que tratam de temas referentes a temas como deuses ou a alma, mas a todo tipo de raciocínio mais abstruso. Por isso, Hume considera necessário verificar o que pode ser dito em defesa desse tipo de filosofia. $\mathrm{O}$ primeiro argumento que ele emprega nesse sentido é chamar a atenção para o modo como os raciocínios abstratos podem auxiliar a filosofia “mais fácil e humana”. Esta, segundo nosso autor, não pode, sem o auxílio da metafísica, chegar a qualquer exatidão em seus sentimentos, preceitos ou raciocínios. “Todas as letras polidas são apenas imagens da vida humana em várias atitudes e situações, e nos inspiram com diferentes sentimentos de louvor ou de censura, admiração ou ridículo, de acordo com as qualidades do objeto que elas colocam diante de nós ${ }^{193}$ ” (HUME 32, p. 90). Nesse ponto, Hume retoma a metáfora do pintor e do anatomista. E o que nosso filósofo nos diz aqui é que um artista, para ser bem sucedido em seus propósitos, deve não apenas ter um gosto delicado, mas também possuir um conhecimento preciso do modo como funcionam o entendimento, as paixões e os sentimentos que diferenciam vício e virtude. Hume admite que essa pode ser uma busca

\footnotetext{
192 “[...] what is commonly called metaphysics $[\ldots] ”$.

193 “All polite letters are nothing but pictures of human life in various attitudes and situations; and inspire us with different sentiments, of praise or blame, admiration or ridicule, according to the qualitites of the object, which they set before us”.
} 
dolorosa, mas a considera indispensável àqueles que quiserem descrever apropriadamente as aparências externas. Quanto ao anatomista, mas uma vez é apresentado como aquele que apresenta aos olhos os objetos mais hediondos, mas também como alguém cuja ciência é útil ao pintor, já que este não poderá, sem conhecer a estrutura do corpo humano, pintar uma Vênus ou uma Helena (HUME 32, p. 90). Além disso, não podemos nos esquecer de que, em qualquer arte ou profissão, por mais conectada à vida comum que ela esteja, não temos como não desejar um certo grau de precisão. E ainda que o filósofo possa viver afastado dos negócios, é desejável que um “espírito filosófico ${ }^{194 »}$ seja cultivado de maneira cuidadosa por muitos para que se difunda gradualmente por toda a sociedade, o que pode conferir uma correção como aquela que vemos na filosofia para todas as artes e vocações. Com isso, Hume considera que todos os campos poderão ser beneficiados, desde a política, já que os governantes, por meio dessa prática, adquiririam maior capacidade de previsão e sutileza, até profissões particulares, como a do advogado, que passará a exercer sua profissão com mais método. (HUME 32, pp. 90-1).

Isso não quer dizer, é claro, que não valeria a pena se dedicar à filosofia mesmo que o seu único benefício fosse a satisfação da curiosidade. Para nosso autor, o caminho da ciência é resultado de se percorrer as trilhas mais doces e inofensivas da vida, e qualquer um que trouxer à ciência contribuições significativas merece ser estimado pelos outros homens. É claro que essas pesquisas podem parecer bastante cansativas, mas, no entender de Hume, existem mentes que são predispostas a elas do mesmo modo que certos corpos saudáveis são capazes de apreciar exercícios físicos. O problema é que a obscuridade em que se encontra a filosofia abstrusa não é considerada por todos apenas cansativa. Ora, como já havíamos dito, o leitor comum vê essa forma de filosofar como uma fonte inevitável de erro. Poderia parecer, então, que a metafísica (sempre entendida, nesse contexto, como raciocínio abstrato ou abstruso), longe de ser uma ciência, decorre totalmente da vaidade humana, sempre desejosa de chegar àquilo que é, em última instância, inacessível. Isso decorreria do fato de superstições populares, incapazes de se defender de maneira justa, recorrerem a raciocínios abstrusos para melhor se fixarem nas mentes dos incautos (HUME 32, p. 91).

\footnotetext{
${ }^{194}$ No original, genius of philosophy.
} 
Exatamente por isso, Hume propõe que os filósofos, ao invés de abandonar quaisquer raciocínios abstrusos, persigam ferozmente o inimigo, ou seja, a superstição. Isso é necessário porque, deixados a si mesmos, os homens, considerados de maneira geral, não abandonarão as justificativas da metafísica simplesmente por ter sido ela fruto de desapontamentos. Além disso, o desespero não pode, definitivamente, ter lugar nas ciências. Ora, há sempre como ter esperança de que as gerações futuras consigam resultados mais significativos do quer as passadas. Aliás, um homem de gênio ${ }^{195}$ certamente se sentirá estimulado, e não abatido, pelas falhas de seus antecessores, até por esperar que a glória esteja reservada para ele próprio. É nesse ponto, então, que Hume propõe sua ciência da natureza humana: ela seria o único meio para livrar as ciências de quaisquer considerações demasiadamente abstrusas, já que, por meio desse estudo, seria possível mostrar aquilo que está ou não ao alcance do conhecimento humano e, portanto, em que investigações vale a pena insistir. Quanto àquilo que não formos capazes de descobrir pela ciência, devemos nos contentar em desistir, assentindo prontamente à impossibilidade de chegar a qualquer conhecimento sólido nesses temas, ou não teremos paz alguma. "E devemos cultivar a verdadeira metafísica com algum cuidado, para destruir aquela que é falsa e adulterada ${ }^{196 ”}$ (HUME 32, p. 92). A indolência pode salvar alguns dessa "filosofia enganadora”, enquanto outros se deixam levar pela curiosidade e, depois de momentos de desespero, alimentam as maiores esperanças, mas, no fim das contas, o único remédio apropriado para todas as pessoas contra a superstição é o raciocínio preciso e justo.

Uma outra vantagem que Hume vê na ciência proposta por ele é que ela permite explicitar operações que, apesar de intimamente presentes a nós todo o tempo, parecem totalmente envoltas em obscuridade sempre que refletimos sobre elas. É preciso, então, realizar uma ciência que se proponha a conhecer as diferentes operações da mente, separá-las, classificá-las. E se não for possível ir além disso, dessa “geografia mental”, nosso filósofo considera que já terá sido bom o suficiente chegar até aí.

Outra vantagem bastante considerável é que não seria possível considerar obscura essa ciência da natureza humana, a não ser que "sustentemos um ceticismo tal

195 Temos, aqui, outra ocorrência da palavra genius no texto original, agora empregada com sentido distinto daquele com o qual ela havia ocorrido da primeira vez.

196 “And must cultivate true metaphysics with some care, in order to destroy the false and adulterate”. 
que é subversivo de toda especulação, e até mesmo de toda ação” (HUME 32, p. 93) ${ }^{197}$. Ora, simplesmente não temos como duvidar de que a mente é dotada de poderes e faculdades, os quais são distintos uns dos outros, sendo que aquilo que é realmente distinto à percepção imediata pode ser distinguido pela reflexão. Portanto, deve haver algo como verdade e falsidade no que diz respeito a esse tema e, principalmente, essa verdade e essa falsidade devem estar ao alcance do entendimento. Ora, há muitas distinções óbvias desse tipo, como, por exemplo, aquela entre entendimento e vontade. Há, é claro, outras mais filosóficas e difíceis, mas mesmo essas não são menos reais, apenas mais difíceis de se compreender. Hume espera, então, que o sucesso em descobrir tais distinções, especialmente aquelas mais filosóficas, ofereça uma prova da solidez desse campo do conhecimento.

Tudo isso dito, nosso filósofo se pergunta se não é possível que essa filosofia, aplicada de maneira cuidadosa e encorajada pela atenção do público, possa descobrir, ao menos em certo grau, os princípios secretos responsáveis pelas operações da mente, do mesmo modo que Newton teria sido capaz de provar, por raciocínios os mais afortunados, as leis que governam as revoluções dos cometas. Hume não descarta imediatamente essa possibilidade, mas considera que não tem como afirmar nada a esse respeito em um momento em que sua investigação está apenas começando, ainda mais quando esse tipo de tentativa é feito o tempo todo por filósofos que agem sem o cuidado que é essencial em uma empreitada como essa. É possível, afinal, que sua ciência da natureza humana não possa chegar tão longe. Ainda assim, essa possibilidade é algo que Hume faz questão de mitigar nesse ponto do texto porque, evidentemente, caso ela chegue a se concretizar, moralistas, críticos e outros pensadores como esses certamente ficarão bastante perplexos.

Hume havia dito que essa busca envolveria a descoberta de distinções mais filosóficas e difíceis. Ele considera que a dificuldade da busca não deve ser vista como prova da falsidade dos princípios a serem descobertos. Para ele, é impossível que aquilo que escapou a tantos homens capazes possa ser desvendado com facilidade. Ainda assim, ele assinala não apenas os ganhos, mas também o prazer que uma contribuição como essa pode acarretar. E se é verdade que o fato de as especulações que ele proporá serem abstratas é uma desvantagem, não uma recomendação, também é verdade que

197 “[...] entertain such a scepticism as is entirely subversive of all speculation, and even action”. 
essa desvantagem pode ser superada pelo cuidado, pela arte e pela fuga dos detalhes desnecessários.

A Seção 1 da Investigação sobre o entendimento humano se encerra com duas esperanças. A primeira é a de unir as fronteiras das duas diferentes espécies de filosofia de que Hume tratou em boa parte desse texto, conciliando "a investigação profunda à clareza e a verdade, à novidade ${ }^{198 \%, ~(H U M E ~ 32, ~ p . ~ 95) . ~ A ~ s e g u n d a ~ e ́ ~ q u e ~ s u a s ~ p e s q u i s a s ~}$ contribuam para minar os fundamentos de uma filosofia abstrusa que, para ele, serve apenas como abrigo para a superstição, o absurdo e o erro.

Dedicamo-nos, nas últimas páginas, a uma leitura relativamente extensa da Seção 1 da primeira Investigação. Podemos, agora, fazer comparações mais detalhadas entre ela e aquilo que Hume havia proposto ao longo do Tratado. Isso nos permitirá perceber justamente aquele aspecto que talvez seja o único em que a concepção de filosofia de nosso autor mudou de maneira bastante perceptível depois de seu trabalho de estreia, a saber, a maneira como a filosofia se relaciona com o vulgo. É claro que isso fica particularmente óbvio quando observamos o final da Seção 1 da primeira Investigação, já que Hume mostra o desejo de "unir as fronteiras das diferentes espécies de filosofia”, algo que o final do Tratado e a carta a Hutcheson mencionada por nós parecem indicar que, inicialmente, nosso autor considerava impossível. Poder-se-ia objetar que, nesses dois textos, Hume apenas emprega a metáfora do pintor e do anatomista, sem falar em diferentes espécies de filosofia nos termos que, posteriormente, utiliza na Investigação sobre o entendimento humano. Entretanto, na Seção 1 desta última obra, fica bastante claro que nosso filósofo vê uma relação bem estreita entre aquilo que ele chamou o anatomista e a filosofia que ele denomina abstrusa, a qual certamente não tem entre seus propósitos a instrução moral do homem comum (característica da filosofia fácil), que, além disso, como o próprio Hume afirma, tende a ver o filósofo como alguém quase inaceitável, que não produz benefício algum para a humanidade. De certo modo, então, não seria exagero considerar que nosso filósofo, ao escrever o Tratado, considerava impossível justamente considerar as duas espécies de filosofia mencionadas na Seção 1 da primeira Investigação.

\footnotetext{
198 “[...] profound enquiry with clearness, and truth with novelty!”.
} 
A consideração inicial da impossibilidade de unir as duas espécies de filosofia fica particularmente evidente quando observamos, na carta a Hutcheson, a afirmação incisiva, por parte de Hume, de que ele consideraria bastante difícil ver os dois caracteres unidos em um mesmo trabalho. Além disso, é interessante notar que, tanto na carta quanto no parágrafo final do Tratado, o anatomista aparece como aquele que pode ser muito apropriado para aconselhar o pintor. Este, portanto, deve aos conselhos do outro o conhecimento das partes que deseja desenhar. Ora, isso não acontece em momento algum na seção inicial da primeira Investigação. Nela, vemos que o pintor ainda deve "prestar atenção à estrutura interna do corpo humano, à posição dos músculos, à constituição dos ossos e ao uso e à figura de toda parte ou todo órgão ${ }^{199, "}$ (HUME 32, p. 90). A ciência do anatomista, então, é útil ao pintor, mas nosso filósofo não fala, aqui, em algo como um aconselhamento de um pelo outro. Antes, parece que a metáfora do pintor e do anatomista permite entrever, antes do parágrafo final da Seção 1, que a intenção de Hume é justamente construir um tipo de texto que é acessível a um público menos restrito que aquele pertencente à academia. Esse é um fato curioso porque, se for assim, o que nosso autor pretende é uma crítica não apenas da maneira como a filosofia abstrusa tem sido recebida, mas também a fácil, já que, sem uma ciência da natureza humana que seja ela própria praticada por aqueles que pretendem atingir os sentimentos de seus leitores, simplesmente não há garantia alguma de que as virtudes que eles tentam inculcar são as mais indicadas, ou que estão colaborando para formar um gosto realmente refinado em seus leitores. Além disso, parece que, sem o auxílio da "filosofia abstrusa”, a "fácil” não teria como pintar seus quadros de maneira tão vívida. No fim das contas, é como se Hume, sem abrir mão de se aproximar do público característico da "filosofia fácil”, fizesse uma crítica ao afirmar que, sem os conhecimentos do anatomista, ela não se basta.

A situação é um tanto diferente quando o que está em jogo é a "filosofia abstrusa”. Vimos que Hume realiza um esforço nada desprezível para defendê-la das opiniões comuns. Isso não se explica apenas pelo fato de ela, por ser menos amplamente aceita, necessitar de uma boa defesa. O que a Seção 1 da primeira Investigação pretende é mostrar que a própria situação complicada em que a "filosofia abstrusa" se encontra é

\footnotetext{
199 “[...] carry his attention to the inward structure of the human body, the position of the muscles, the fabric of the bones, and the use and figure of every part or organ”.
} 
uma evidência bastante clara de que ela precisa de uma reforma nada menos que urgente. Sem os artifícios dramáticos do Tratado, é relativamente fácil perceber que, se a filosofia abstrusa permanecer onde está, corremos o risco de que ela perca completamente sua credibilidade no "mundo real” e que, aos partidários dela, não reste nada senão um diálogo de surdos. Isso porque, entre outras coisas, os falsos filósofos de que falamos nos dois primeiros capítulos são, de maneira geral, filósofos abstrusos e, como vimos, constroem sistemas completamente separados do mundo da experiência e, reféns de uma razão que adere prontamente a um princípio preferido para o qual sempre é possível arrumar mais uma justificativa, dificilmente poderiam se abrir, de fato, para outro sistema. Nesse contexto, então, o que Hume pretende é aproximar a "filosofia abstrusa” do senso comum, e esse é um propósito importante de sua ciência do homem. Delimitar aquilo que é possível conhecer, reduzindo toda filosofia possível ao campo da experiência, termina por se mostrar, na primeira Investigação, não apenas um modo de fazer dos filósofos homens bem semelhantes a todos os outros, mas, também, permitir que os homens comuns possam se beneficiar em alguma medida de empreendimentos filosóficos. Podemos dizer, então, que nosso autor se deu conta de que a melhor maneira de tornar efetiva a submissão da filosofia à “moralidade prática”, algo que ele afirmava pretender já mesmo ao final do Tratado, era justamente pela junção entre os caracteres do pintor e do anatomista e, para isso, é necessário reabilitar este último junto ao público que sempre dera sua preferência ao pintor, o que só pode ser feito mediante a apresentação de uma filosofia que cumpra uma condição que é apresentada de maneira bastante explícita ao longo da Seção 1 da Investigação sobre o entendimento humano, a saber, a humanização que permitirá aos raciocínios abstrusos recuperarem, de algum modo, ao menos alguma estima junto ao grande público. Hume, portanto, deve mostrar e que modo é viável (apesar de difícil, já que o grande público desconfia prontamente de qualquer forma de pensamento que se coloque como demasiadamente abstrusa ou abstrata), em sua ciência do homem, a aceitação de raciocínios que escapem à meral filosofia fácil. E é isso que torna essencial uma investigação profunda e detalhada acerca dos princípios que são responsáveis por aquilo que chamamos conhecimento. A impressão que fica é que Hume teria iniciado a primeira Investigação fazendo algumas considerações que vemos apenas no final do Livro I do Tratado simplesmente porque há, no texto de maturidade, uma preocupação maior em explicitar, de início, o projeto de filosofia que lá se delineia e, também, porque a proximidade da filosofia com o senso 
comum ganha, na primeira Investigação, uma dimensão que talvez o Hume do Tratado simplesmente não fosse, ainda, capaz de atribuir a ela.

Acreditamos ter estabelecido, então, que Hume, em suas obras posteriores àquela com que iniciou sua carreira filosófica, passou a ver a filosofia não apenas como algo que deveria compartilhar certos princípios com o senso comum, ou limitar-se a corrigi-lo de modo que fosse perceptível apenas para aqueles que se encontravam nas universidades, mas como algo que deveria ser acessível a um público mais amplo. Devemos, então, atentar para o público que nosso autor tem em vista. Ao falarmos em uma filosofia que pretende atingir diretamente o homem comum, não estamos, é claro, falando em “qualquer” homem comum. Já na “Conclusão” do Livro 1 do Tratado, Hume havia feito referência a homens totalmente ignorantes de qualquer filosofia que não são, por conta disso, menos honestos ou felizes, e ele não parece preocupado em abandonar essa posição. Ainda assim, é preciso que o filósofo, quando se dirigir aos homens comuns, tenha em mente, é claro, aqueles que se interessarem de algum modo pelo seu trabalho, e esses leitores em potencial podem ser encontrados, sobretudo, naquela que, hoje em dia, chamaríamos classe média. Mais do que isso, em um ensaio intitulado "Of the Middle Station of Life”, Hume faz um verdadeiro elogio dessa classe social, considerando-a "a mais numerosa ordem de homens que se pode supor serem suscetíveis à filosofia", de modo que "todos os discursos sobre moralidade devem ser endereçados principalmente a eles ${ }^{200 », ~(H U M E ~ 37, ~ p . ~ 546) . ~ E ́ ~ i n t e r e s s a n t e ~ o b s e r v a r m o s ~}$ que essa formulação tem um fundamento bastante prático; nosso autor considera que as coisas se dão dessa forma porque os ricos estão demasiadamente imersos em prazer e os pobres, ocupados demais tentando satisfazer as "necessidades da vida" e, desse modo, nenhuma dessas duas classes pode, em geral, assentir tão facilmente à voz da razão.

Além de considerar a "middle station" mais apropriada para a prática da filosofia, Hume também acredita que ela é favorável a certas virtudes que também não são tão fáceis de adquirir entre os muitos ricos ou os muito pobres. Uma delas é a amizade, já que esta ocorre principalmente em iguais. Os muito pobres podem frequentemente ver a amizade que oferecem ser rejeitada e os muitos ricos podem certamente fazer muitas amizades, mas não podem ter certeza de que elas são sinceras.

200 “These form the most numerous Rank of Men, that can be suppos'd of Philosophy; and therefore, all Discourses of Morality ought principally to be address'd to them”. 
Além disso, a sabedoria e a habilidade também parecem ser favorecidas pela "classe média”, já que essa situação social nos põe em uma posição em que temos melhores chances de conhecer homens e coisas do que aquela que se encontram os, por assim dizer, grandes homens. O homem da "middle station” tem tempo livre o suficiente para observar o mundo e, além disso, os motivos da ambição, que o incitam a agir, já que homens dessa classe não têm qualquer esperança de fazer uma boa figura de si mesmos senão por sua própria indústria e, portanto, pela melhoria de suas habilidades (HUME 37, pp. 547-8).

É relativamente tentador vermos esse elogio como bastante natural da parte de Hume, um filósofo que nasceu em uma família respeitável, mas não opulenta, e que não era o filho mais velho e, portanto, não herdaria a propriedade de seus pais. Sabe-se que nosso autor não pode se dedicar apenas à filosofia desde o início e que tentou uma carreira no comércio, além de ter participado de uma expedição militar e trabalhado como preceptor e como bibliotecário, e que parte dessas profissões foram exercidas por ele como simples meio de atingir a independência financeira com a qual ele nem sempre pode contar ${ }^{201}$. Essas razões autobiográficas, entretanto, não parecem dar conta do que Hume pretende em “Of the Middle Station of Life”. Quanto àqueles que estão em uma situação social muito ruim, podemos observar com segurança que, à época, eram, em sua maioria, analfabetos ${ }^{202}$. Com relação aos muitos ricos, podemos dizer que não eram

\footnotetext{
${ }^{201}$ Ernest Mossner nos oferece um bom grau de detalhamento da vida de Hume anterior à fama e deixa bastante claro que nosso filósofo, por algum tempo, não tinha dinheiro o bastante para garantir sua independência financeira. Esse biógrafo nos conta, ainda, sobre o modo como Hume exerceu cada uma das atividades que mencionamos. Algumas delas, como a de bibliotecário, podem ter sido importantes porque a volumosa Biblioteca dos Advogados de Edimburgo provavelmente continha volumes com que Hume não teria tido contato de outra maneira. A de preceptor também pode ter sido importante do ponto de vista da obra humiana, já que ocorreu em um período em que nosso autor buscava um trabalho em um lugar tranquilo, o que ele acreditava que o favoreceria na escrita de sua História da Inglaterra (não deixa, portanto, de ser irônico que, infelizmente, essa atividade tenha trazido a Hume mais problemas do que tranquilidade). Ainda assim, os "outros empregos" de Hume certamente foram motivados pela necessidade de se tornar independente financeiramente. De qualquer maneira, a expedição militar fracassada de que Hume participou e seu período como preceptor rendem algumas anedotas interessantes, bem como algumas narrações bastante dramáticas por parte de Mossner.
}

${ }^{202}$ Em um artigo intitulado "Hume and the Common People", David Chisick mostra, para além de qualquer dúvida, que nosso filósofo estava longe de ter uma visão favorável dos extratos sociais menos favorecidos, ainda que não considerasse as pessoas pertencentes a essas classes os monstros que, de 
vistos por nosso filósofo com ressentimento ou qualquer coisa do tipo. Parece, então, que o elogio de Hume nesse ensaio é, antes de qualquer coisa, um elogio, justamente, daquele tipo de leitor que ele busca atingir e, mais do que isso, do público que ele considera com que a verdadeira filosofia deve estar em contato. O critério, como o próprio texto de Hume deixa bastante claro, é, antes de qualquer outra coisa, prático.

Outro motivo pelo qual esse ensaio é interessante é que ele nos permite corroborar a tese de que nosso autor, nos textos posteriores ao Tratado, buscou atingir um público maior do que apenas os eruditos. Isso não quer dizer que ele quisesse tornar filósofos todos os homens comuns, mas certamente acreditava que, em alguma medida, a filosofia poderia resultar em benefícios no mínimo como aqueles que são apresentados em “Of Essay Writing”. Na verdade os benefícios que Hume atribui a ela são ainda maiores, como podemos ver na Seção 1 da primeira Investigação. Em sua forma "fácil”, a filosofia incita os homens à virtude e colabora para a regulação das paixões. Em sua forma "abstrusa” faz com que nos tornemos raciocinadores melhores e nos imbui do espírito de precisão que, como já vimos, é útil em qualquer tarefa.

\section{A experiência como participação e a correção do senso comum}

A esta altura, simplesmente não temos como negar que Hume, a partir de um dado momento, passou a ver a filosofia como algo que deve se aproximar do senso comum em duas frentes. Primeiramente, vimos que é preciso que o filósofo aceite a experiência como aquilo que determina o que é possível conhecer e, a partir de um

\footnotetext{
maneira geral, os fidalgos acreditavam que elas fossem. Ainda que em linhas gerais tendamos a concordar com a posição de Chisick, devemos observar que o Hume que recomenda a filosofia à “classe média” não o faz por mero elitismo (ou a filosofia seria recomendada aos mais ricos, não?), mas por critérios que, como tentamos deixar claro no corpo do texto, são apenas práticos. Isso não quer dizer, é claro, que Hume não tivesse seus preconceitos de classe, ou que eles ocasionalmente não apareçam no texto. Entretanto, uma análise por esse viés é algo que não teríamos competência para realizar e que, principalmente por motivos metodológicos, podemos tranquilamente escolher não realizar. O que nos interessa no momento, como o leitor certamente já percebeu, não é vincular Hume a qualquer posição política contemporânea, muito menos correr um risco em que Chisick certamente incorre (ainda que acreditemos que ele se desembaraça dele com bastante eficácia), a saber, o de fazer uma caricatura da posição da qual o "nosso" Hume fosse aproximado.
} 
estudo rigoroso da natureza humana, aceite que a esfera em que suas especulações podem funcionar é limitada por um mundo que ele compartilha com o homem comum e, mais ainda, com uma razão que, longe de ser divina e infalível, é compartilhada não apenas com o homem comum, mas, também, com os animais. Por outro lado, o próprio homem comum terá na verdadeira filosofia algo que o ajudará a se manter no caminho da virtude e fará com que ele tenha uma ferramenta importante que poderá usar em todas as suas atividades. Faz sentido, então, que exploremos de que modo o conceito de experiência proposto por Hume e a sua colocação da filosofia como "sistematização e correção” das reflexões da vida comum permitem que essa relação seja desenvolvida.

A afirmação de que “decisões filosóficas são apenas as reflexões da vida comum, metodizadas e corrigidas” aparece, como já vimos, na Seção 12 da primeira Investigação. Essa seção reafirma que tudo aquilo que podemos conhecer é dado, de um lado, pela matemática e pela geometria e, por outro, pelos raciocínios sobre questões de fato. E como até mesmo o leitor mais casual da obra de Hume percebe, é dos raciocínios sobre questões de fato que trata a sua teoria do conhecimento, tanto na Investigação sobre o entendimento humano quanto no Livro 1 do Tratado. Defendemos, no capítulo anterior, que a grande inovação de Hume no que diz respeito aos processos pelos quais conhecemos o mundo que se nos apresenta é mostrar que eles não se dão por meio da razão tradicional, mas de um processo basicamente instintivo, por certas propensões. Propusemos, além disso, que isso não o torna menos cético no que diz respeito a questões como relações causais ou o mundo exterior ${ }^{203}$. Finalmente, concluímos que a mescla entre ceticismo e naturalismo na teoria do conhecimento humiano é justamente o que permite o início da aproximação com o senso comum, na medida em que, ainda que não possamos justificar certas crenças básicas e, mais do que isso, ainda que a razão possa desmontá-las com relativa facilidade, é preciso, de qualquer maneira, que continuemos a assentir a elas e, mais do que isso, simplesmente não temos outra escolha. No Tratado, como também já mostramos, a situação é um pouco mais confusa,

\footnotetext{
${ }^{203}$ Parece desnecessário, mas, de qualquer maneira, talvez seja o caso de esclarecermos que isso nos põe em desacordo, no que diz respeito ao tipo de ceticismo defendido por Hume, não apenas com aqueles que têm tomado posições explicitamente favoráveis a um possível "novo Hume" no debate que tem se desenrolado nesse sentido, mas também com relação a autores como Norman Kemp Smith e Donald Livingston, que, ainda que nem sempre insistam nesse ponto, parecem ver no naturalismo de Hume uma passagem possível para alguma forma de realismo.
} 
já que, em alguns momentos, a crença causal parece ter uma intensidade como aquela da educação, que é mesmo capaz de suplantar a crença causal, ainda que haja menções à possibilidade de se corrigir a crença pela reflexão. Na primeira Investigação, parece não haver dúvidas de que o primado da experiência está assegurado, bem como seu papel normativo. Isso fica claro na Seção 10, em que a crença em milagres é apresentada como uma grande insensatez que exige praticamente um "milagre” para que o próprio crente acredite (HUME 32, p. 186), e na Seção 11, em que Hume procura mostrar, por meio de um diálogo, que o argumento do desígnio simplesmente não pode ser aceito nas mesmas bases em que são aceitos os argumentos experimentais válidos, seguindo uma linha que seria bem mais desenvolvida, posteriormente, nos Diálogos sobre a religião natural.

Já deve estar suficientemente claro, então, que o próprio recurso à experiência enquanto norma é, ele próprio, uma tentativa, por parte de nosso filósofo, de se aproximar do senso comum e, mais do que isso, de fazer da filosofia, mesmo já no Tratado, uma "metodização e correção" do senso comum. Isso será importante tanto para definir os temas a que os filósofos poderão se dedicar e os métodos que empregarão quanto, posteriormente, os modos como será possível que a filosofia busque atingir o leitor comum que pretender voltar sua atenção a ela. Essa interpretação se fortalece quando observamos mais uma característica disso que Hume denomina experiência. Para investigá-la, parece conveniente começarmos citando a seguinte passagem da Seção 10 da primeira Investigação:

O príncipe INDIANO que se recusou a acreditar nos primeiros relatos concernentes aos efeitos do congelamento raciocinou justamente, e era natural que fosse preciso um testemunho muito forte para conseguir o seu assentimento a fatos que haviam surgido em um estado da natureza com que ele não estava familiarizado, e que contava com analogias tão pequenas com relação àqueles eventos de que ele tinha tido uma experiência constante e uniforme. Ainda que eles não fossem contrários à sua experiência, não estavam em conformidade com ela ${ }^{204}$. (HUME 32, p. 172).

\footnotetext{
204 “The INDIAN prince, Who refused to believe the first relations concerning the effects of frost, reasoned justly; and it naturally required very strong testimony to engage his assent to facts, that arose from a state of nature, with which he was unacquainted, and which bore so little analogy to those events, of which he
} 
Essa passagem ocorre, como já vimos, na seção da primeira Investigação em que Hume trata dos milagres e da confiabilidade dos testemunhos. De qualquer maneira, permite que percebamos um aspecto importante daquilo que vimos chamando experiência. Ainda que o hábito nos permita criar certas leis gerais, como o princípio segundo o qual a natureza manterá sua ordem e aquele segundo o qual seremos levados a acreditar na causalidade de maneira geral, ou seja, que as ocorrências do mundo percebido têm causas, não é possível, como também já deve ter ficado claro a esta altura, que julguemos algo de que simplesmente não tivemos experiência alguma. Em uma nota de rodapé, Hume tece mais algumas considerações sobre o caso do príncipe indiano. Nela, afirma que é impossível dizer a priori o que resultará em uma situação completamente desconhecida. Além disso, um evento como o congelamento da água foge a quaisquer regras de analogia a que um indiano sensato poderia recorrer. Como sabemos, a água não vai se congelando gradualmente conforme a temperatura diminui, mas, como observa nosso filósofo, "quando quer que chegue ao ponto de congelamento, a água passa em um momento da maior liquidez à perfeita dureza ${ }^{205 ”}$ (HUME 32, p. 172). Ainda que não possa ser considerado miraculoso, esse evento certamente seria considerado extraordinário por um habitante de um país em que a água jamais atinge a temperatura necessária para congelar, mas que nunca pode observar, por exemplo, o que acontece com os lagos finlandeses durante o inverno.

Ainda que um evento desse tipo certamente exija um testemunho bastante forte para que possamos acreditar nele, ele tem uma natureza bastante diferente daquela que observamos nos milagres simplesmente porque diz respeito à própria experiência. Não há quem tenha visto um homem se levantar efetivamente dos mortos (é claro que não consideramos, ao fazer essa afirmação, os casos de catalepsia) e, como sabemos, é exatamente isso que faz com que um evento desse tipo seja milagroso. Ao aceitar a hipótese de um tal acontecimento, o que acontece é que estamos reconhecendo que algo que seria simplesmente impossível de acordo com qualquer raciocínio causal pode ser verdade. O caso do príncipe indiano é diferente porque estamos lidando com algo que,

had had constant and uniform experience. Though they were not contrary to his experience, they were not conformable to it”.

205 “ $[. .$.$] whenever it comes to the freezing point, the water passes in a moment, from the utmost liquidity$ to perfect hardness”. 
ainda que não fosse conforme a experiência dele, poderia, em outro contexto, ser comprovado pelos mesmos métodos de raciocínio que o haviam levado a duvidar que a água congele. Ainda assim, esse caso nos leva a atentar para uma característica de qualquer raciocínio a partir da experiência. Ela pode ser vista, também, como algo que é sempre, em certa medida, particular ou, no máximo, social, já que frequentemente aceitamos depoimentos dos outros e, além disso, a educação é responsável por parte considerável de nossas crenças. O que ocorre é que, como já vimos, Hume confere à experiência um valor normativo e, portanto, devemos desconfiar de relatos que não se conformem a ela, mesmo que isso nos leve a crer que a água não pode ser tornada sólida. Essa correção só pode ser providenciada pela própria experiência e, assim, o máximo que o indiano pode fazer é não aceitar nem recusar o relato que recebeu ${ }^{206}$.

Esse aspecto da experiência é importante porque terminará como implicar uma concepção segundo a qual o filósofo deverá sempre levar em conta aquilo que já está dado no universo em que encontra. Isso pode ser verificado especialmente na Investigação sobre os princípios da moral. Nesse aspecto, não nos parece que houve grandes mudanças teóricas nesse texto, quando comparado ao Livro 3 do Tratado da natureza humana, mas, neste último, o propósito de nosso filósofo parece ser o de estudar os princípios da natureza humana para explicar (e, ao menos em certa medida, justificar) instituições como o governo, a propriedade e, é claro, a aprovação e a censura por certas virtudes já dadas. A segunda Investigação, por sua vez, tem uma vantagem no que diz respeito ao ponto que procuramos estabelecer: nessa obra, depois de algumas considerações sobre a benevolência, a moralidade é considerada, primeiramente, a partir de certos eventos particulares, com generalizações sendo feitas apenas posteriormente $^{207}$. Quando isso não acontece, Hume trata de oferecer uma quantidade

${ }^{206}$ No Tratado, a correção da experiência parece poder se dar, também, por meio da reflexão, como insiste Norman Kemp Smith em vários pontos de seu The Philosophy of David Hume. Somos obrigados a admitir que talvez essa seja uma diferença entre a epistemologia do Tratado e a da primeira Investigação, mas, por outro lado, ele não interfere radicalmente no ponto que procuramos estabelecer, já que o que nos interessa aqui é mostrar a experiência como algo limitado, sendo que a filosofia deverá, no fim das contas, ensinar como processá-la, quais os aspectos que são relevantes para se instituir relações válidas.

${ }^{207}$ Parte dos intérpretes da teoria moral de Hume, como, por exemplo, Michel Malherbe, defende que o próprio fundamento da moralidade, na segunda Investigação, passa a ser a benevolência, enquanto, no Tratado, ele seria a noção de simpatia. Essa posição, é claro, não é compartilhada por todos os comentadores da moral humiana. Vários outros comentadores, por outro lado, opõem-se a ela. Não nos 
considerável de exemplos que permitem que o leitor veja as teses expostas se desenrolando ao longo da história. Acreditamos que isso cumpre três propósitos principais. O primeiro deles é evidenciar ainda mais a matriz experimental de que Hume pretende tirar suas conclusões. O uso dos exemplos evidencia, ainda, a preocupação que nosso filósofo teria tido, ao escrever a segunda Investigação, em tornar seus textos mais acessíveis para o leitor comum. Nesse sentido, o procedimento adotado por nosso autor ao longo desse trabalho corrobora as considerações que fizemos sobre a mudança, na filosofia humiana, da relação do filósofo com o público ou, ao menos, no perfil do público que ele procurava atingir. Finalmente, ao mostrar a construção da moralidade com base em exemplos concretos, Hume pode apresentar de maneira mais eficiente uma concepção segundo a qual as considerações de um povo sobre temas morais podem evoluir ao longo do tempo, com instituições que se tornam inúteis ou perniciosas sendo descartadas em favor de outras que podem trazer resultados benéficos para a sociedade $^{208}$. Em que sentido, entretanto, essa mudança faz com que consideremos a segunda Investigação um texto mais apropriado para que continuemos a mostrar a experiência como algo que, para Hume, é também ela algo que se define no âmbito pessoal e/ou social?

A resposta, na verdade, é relativamente simples. O que acontece é que, em várias ocasiões, pode não haver uma única regra que indique de que modo esta ou aquela instituição social deve se desenvolver. É verdade que, na segunda Investigação e, ao menos em certa medida, também no Tratado, a razão tem um papel importante no estabelecimento das distinções morais. É ela que informa aquele que julga uma ação das circunstâncias necessárias para que ele possa considerar se ela teria sido útil ou perniciosa, seja ao agente, seja para a sociedade. Isso fica bastante claro, por exemplo, na seguinte passagem do Apêndice 1 da segunda Investigação:

deteremos, aqui, nessa discussão, que parece completamente alheia àquilo que tentamos estabelecer. Pelo mesmo motivo, não detalharemos os argumentos utilizados por cada um desses “partidos”. De qualquer maneira, sendo esse um tema recorrente nas discussões sobre a teoria moral de Hume, consideramos que seria importante ao menos indicá-lo.

\footnotetext{
${ }^{208}$ Acreditamos que seria desnecessário avisar, mas, de qualquer maneira, informamos que “moral”, nesse contexto, não tem o sentido mais amplo que Hume por vezes atribui a essa palavra, mas simplesmente o sentido em que ela pode ser equiparada a “moralidade”.
} 
[...] em deliberações morais, devemos estar familiarizados de antemão com todos os objetos e todas as relações de uns com os outros e, a partir de uma comparação do todo, fixamos nossa escolha ou nossa aprovação. Nenhum fato novo deve ser estabelecido. Nenhuma nova relação, ser descoberta. Todas as circunstâncias do caso estão, supostamente, colocadas diante de nós antes que possamos fixar qualquer sentença de culpa ou de aprovação ${ }^{209}$. (HUME 33, p. 160)

Somente depois de conhecidas todas as circunstâncias, então, é que é possível que alguém seja acometido pelo sentimento apropriado de aprovação ou de censura. Isso, entretanto, não resolve um outro problema, a saber, o do desenvolvimento da moralidade. Se no Tratado o tom adotado por Hume indicava que sua maior preocupação era oferecer uma explicação para o modo como as virtudes haviam chegado ao ponto em que ele as encontrara, na segunda Investigação parece haver um cuidado considerável em mostrar a moralidade como algo bastante particular, que só pode ser entendido quando observado no interior do grupo a que se refere. Isso fica evidente em pelo menos duas passagens. Uma delas é aquela em que Hume se refere a uma hipotética sociedade de ladrões, na Seção 3. É claro que o objetivo principal dessa passagem é mostrar que, sem uma justiça instituída, não podemos agir de acordo com as regras de justiça que conhecemos ${ }^{210}$. Outro, que parece mais interessante para os fins

209 “[...] in moral deliberations, we must be acquainted, before-hand, with all the objects, and all their relations to each other; and from a comparison of the whole, fix our choice or approbation. No new fact to be ascertained: No new relation to be discovered. All the circumstances of the case are supposed to be laid before us, ere we can fix any sentence of blame or approbation”.

${ }^{210}$ Evidentemente, temos aí um eco hobbesiano, mas não podemos partir daí para concluir que Hume era, ele próprio, um hobbesiano, já que, como vimos, ele rejeita completamente a hipótese de que o amor próprio possa ser o fundamento da moralidade. O que acontece na teoria de humiana é que, ainda que esta possa surgir, em um primeiro momento, por interesse, ela fornece à simpatia (ou, no caso da segunda Investigação, à benevolência, se acreditarmos nos comentadores que afirmam ter ocorrido essa mudança) as condições de se desenvolver, de modo que passemos a nos importar genuinamente não apenas com aqueles que nos são próximos, mas com o próprio bem público. Desse modo, ainda que Hume tenha um ponto de partida ao menos parcialmente hobbesiano (e que é ainda mais semelhante àquele adotado por Mandeville do que àquele de Hobbes), fica claro que ele aceita o surgimento da sociedade por interesse porque isso permite a ele desferir contra aqueles que denomina céticos morais um golpe muito mais vigoroso, mostrando que a partida de um registro puramente fatual não implica que o amor próprio é o fundamento da moralidade. Ver, a esse respeito, LIMONGI 51. 
que temos em vista aqui, ocorre no diálogo que encerra a segunda Investigação. Esse é um texto que parece ter duas lições principais. Uma delas diz respeito às "vidas artificiais” de que tratamos no segundo capítulo. A outra, de que esta em certa medida depende, é que os princípios que determinam a moralidade são poucos e, no fim das contas, podem ser reduzidos à nossa propensão a aprovar aquilo que é útil e/ou agradável e censurar aquilo que é pernicioso e/ou desagradável, mas, ainda assim, permitem uma boa quantidade de diferenças no modo como as sociedades constroem suas regras morais particulares. Isso reforça uma observação que Hume já havia feito na Seção 3:

Às vezes, os interesses da sociedade podem requerer uma regra de justiça em um caso particular, mas não determinar qualquer regra em particular, entre várias que são igualmente benéficas. Nesse caso, as mais fracas analogias são agarradas, de modo a evitar a indiferença e a ambigüidade que seria a fonte da discórdia perpétua ${ }^{211}$. (HUME 33, p. 92)

Parece, então, que esse é um motivo para o surgimento de maneiras pelas quais se torna possível que a moralidade, ainda que surja sempre dos mesmos princípios básicos, possa variar em diferentes povos conforme outros fatores interferem em seu desenvolvimento. Temos outro exemplo bastante claro disso no diálogo que encerra a segunda Investigação. Depois de afirmar que é bastante difícil justificar tanto a galhardia francesa quanto a grega, Hume afirma que a primeira delas é mais natural e mais agradável que a outra, mas também que os franceses "resolveram sacrificar parte dos prazeres domésticos em favor dos sociais, e preferem a facilidade, a liberdade e um comércio aberto a uma fidelidade e uma constância estritas”. Afirma, ainda, que esses dois fins "são ambos bons, e algo difíceis de reconciliar; e não precisamos nos surpreender se os costumes das nações se inclinam demais às vezes para um lado, às vezes para outro $^{212, "}$ (HUME 33, p. 193).

\footnotetext{
211 "Sometimes, the interests of society may require a rule of justice in a particular case; but may not determine any particular rule, among several, which are all equally beneficial. In that case, the slightest analogies are laid hold of, in order to prevent that indifference and ambiguity, which would be the source of perpetual dissention".

212 "[...] have resolved to sacrifice some of the domestic to the sociable pleasures; and to prefer ease, freedom, and an open commerce to a strict fidelity and constancy. These ends are both good, and are
} 
Esses exemplos deixam bastante claro que, no fim das contas, as instituições sociais não são, para Hume, algo completamente fixo. Estão, isso sim, em constante mudança, conforme mantém ou perdem sua utilidade e, além disso, é possível que mais de uma solução se mostre útil, ou que, no curso de suas sucessivas adaptações, um povo se veja em um caso em que terá que escolher entre dois bens. Isso nos diz algo importante a respeito de como o filósofo deverá operar quando se dedicar a questões específicas em moral ou em política. A não ser que pretenda romper radicalmente com a experiência, ele deverá buscar fazer críticas ou correções sempre a partir do que já está dado e, longe de propor quaisquer grandes revoluções (que implicariam a destruição do objeto que se procura corrigir), deverá se limitar a corrigir aspectos que parecem não funcionar. Mais do que isso, Hume passa a impressão de que sempre devemos adotar, ao considerar qualquer sociedade, o ponto de vista de alguém que participa dela. O diálogo ao fim da segunda Investigação não procura rejeitar a moral grega ou a francesa, mas compreender os aspectos que as engendraram. Do mesmo modo, Hume não faz, mesmo em outros pontos dessa obra, afirmações do tipo “a moral romana é ruim”. O que é possível fazer é evidenciar os princípios da natureza humana e as circunstâncias que teriam sido responsáveis por aquela moral, o que resulta em uma forma de crítica que apontará quais os aspectos mais ou menos apropriados para aquele “sistema” em particular. Quanto a eventuais correções, devem ser feitas sempre a partir daquilo que estiver dado e, portanto, serão correções da própria coisa que se apresenta, não uma revolução ou algo desse tipo ${ }^{213}$.

Esse ponto se torna bastante evidente quando observamos, por exemplo, o ensaio “Of Moral Prejudices”, em que Hume faz um verdadeiro elogio dos preconceitos que se apresentam no seio da vida comum. Depois de apresentar a filosofia estoica como algo

somewhat difficult to reconcile; nor need we be surprised, if the customs of nations incline too much, sometimes to the one side, sometimes to the other".

213 Nesse aspecto, tendemos a concordar com Donald Livingston. Ainda que não possamos concordar com a caracterização que ele faz do que seria, para Hume, um "filósofo heroico" caracterizado pela “culpa filosófica”, certamente parece que ele capturou muito bem o fato de que um filósofo como Marx, que, de acordo com o que estabelecemos, pareceria a Hume um falso filósofo simplesmente porque suas críticas "não buscariam reformar a sociedade de que se é um participante leal, mas transformar totalmente um objeto alienígena” [would not be to reform the society in which one is a loyal participant but to totally transform an alien object] (LIVINGSTON 53, p. 27). 
por que "Os sentimentos virtuosos e suaves, ou preconceitos, se você preferir, sofreram

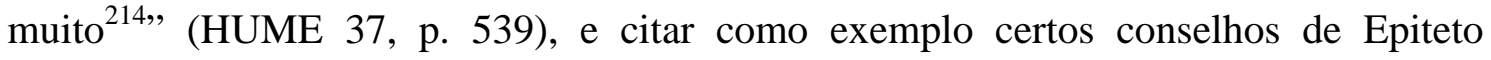
segundo os quais devemos afetar simpatia por um amigo para consolá-lo, mas sem permitir que qualquer compaixão penetre nossos corações, Hume nos apresenta a história de um homem chamado Eugênio. Este seria um homem que se dedicou desde cedo à filosofia e jamais se desviava dela, a não ser quando tinha a oportunidade de servir a seus amigos ou agradar algum homem de mérito. Por volta dos trinta anos, Eugênio decidiu abandonar a vida de solteiro não porque ela lhe desagradasse (pelo contrário), mas porque era o último daquele ramo de sua família, de modo que esta apenas poderia continuar se ele tivesse descendentes. Casou-se, então, com Emira, mulher bela e virtuosa, que, depois lhe dar muitos filhos, faleceu. Eugênio, que chegara a amar sua esposa, só pode ser consolado por sua jovem família, a quem ele se afeiçoou ainda mais por consideração à sua esposa. Ainda que preferisse uma filha que lembrava sua esposa, escondeu,tanto quanto possível, sua parcialidade. Eugênio preservou para sempre as lembranças de sua esposa e sempre chorava no aniversário dela; além disso, queria ser enterrado junto a ela, tendo até mesmo composto um epitáfio para celebrar seu amor (HUME 37, PP. 540-1).

Hume compara essa história, então, à de uma jovem rica e bem nascida que, sozinha, pretende persistir na vida de solteira, mas, ainda assim, deseja ter um filho. O casamento está fora de questão porque a tal jovem presenciou uma série de casamentos infelizes e ouviu inúmeras reclamações acerca de maridos tirânicos, inconstantes, ciumentos ou indiferentes. A jovem tem grande força de espírito e, assim, não cederá de modo algum à tentação de se casar. Pretende apenas ter um filho e dedicar-se exclusivamente à sua educação. Conhece, um dia, um jovem chamado Parterre, e acredita que ele pode ser o homem agradável que por muito tempo ela havia procurado para gerar uma criança. Nossa heroína começa uma amizade com o jovem, que, apesar de receoso devido às diferenças de intelecto e de fortuna entre eles (nossa heroína parece muito superior nesses dois aspectos), encanta-se com ela. Quando descobre que Parterre tem um espírito condizente com sua bela aparência, a "heroína filosófica" decide que não há mais testes a fazer e, então, comunica a ele suas reais intenções. Depois de algum tempo, da à luz um filho homem. Ela não se importaria de continuar

214 “The virtuous and tender Sentiments, or Prejudices, if you will, have suffer'd mightily [...]”. 
sua amizade com Parterre, mas descobre que ele está demasiadamente apaixonado e, por conta disso, corta relações com ele. Concede-lhe mil coroas por ano, mas pede a ele que nunca mais a veja e, se possível, esqueça as familiaridades que se passaram entre os dois. Esse relato se encerra com a informação de que o rapaz processou nossa heroína, exigindo o direito de educar seu filho. A heroína, em sua defesa, torna público o acordo que havia sido feito. O caso parece confuso tanto para advogados quanto para filósofos. (HUME 37, pp. 542-4).

Esse ensaio é, como já dissemos, um elogio dos preconceitos morais, entendidos aqui como as normas sociais estabelecidas pela vida comum. Os preconceitos são mostrados como "sentimentos virtuosos e suaves" e a história de Eugênio tem por objetivo justamente mostrar uma personagem que, apesar de estudiosa da filosofia, mantém os compromissos e os sentimentos que a vida social lhe impõe. A história de nossa “heroína filosófica”, por sua vez, é precedida pelas seguintes considerações:

Ele [o relato] contém um caso de espírito filosófico tal que considero bem extraordinário, e pode servir de exemplo para que não nos desviemos demais das máximas aceitas de conduta e comportamento por conta de uma busca refinada pela felicidade ou pela perfeição ${ }^{215}$ (HUME 37, p. 542).

A lição de Hume parece, então, bastante clara. O amor pela filosofia é saudável se não nos desviar de um curso que é, de maneira geral, determinado pelas obrigações sociais já estabelecidas. Temos aí, também, a confirmação de algo que já havia sido dito, a saber, que, aparentemente, o curso de vida que a natureza nos recomenda é aquele em que nos dedicamos igualmente aos negócios, à convivência e à reflexão filosófica. Ainda que, pelas considerações sobre Epiteto, parece que seria permitido ao estoico ter amigos, a maneira como se dá, para eles, a relação entre o filósofo e seu colega “comum” não abre espaço para a compaixão, o que evidencia que, ao interagir com as pessoas que o cercam, o estoico não o faz imbuído de uma moral determinada pela expansão da simpatia, como Hume considera que as coisas efetivamente se dão no mundo. O verdadeiro filósofo, por outro lado, deverá aceitar a moralidade tal como ela

\footnotetext{
215 "It contains such an Instance of a Philosophic Spirit, as I think pretty extraordinary, and may serve as an Example, no to depart too far from the receiv'd Maxims of Conduct and Behaviour, by a refin'd Search after Happiness or Perfection”.
} 
acontece e, se for o caso de corrigi-la, isso se dará com base em pontos particulares que se mostram inviáveis e, é claro, sempre respeitando os princípios que a própria experiência mostraram ser aqueles que determinam a evolução da moral socialmente constituída. Aliás, no que diz respeito a corrigir a moralidade, parece que a própria história é capaz de se encarregar, ao menos, de boa parte do processo. Isso fica aparente não apenas nas várias passagens em que Hume afirma que os homens comuns são suficientemente sábios em questões morais, mas também em casos particulares, como, por exemplo, o comentário que vemos sobre o tiranicídio na Seção 2 da Investigação sobre os princípios da moral. Para Hume, ele era algo comum na antiguidade porque então se considerava que ele poderia servir para livrar o povo de príncipes usurpadores e assassinos, mas, posteriormente, foi abandonado porque a história e a experiência convenceram a todos de que essa prática, ao invés de tornar os príncipes menos propensos à tirania, tinha por resultado aumentar a crueldade deles (HUME 33, p. 81). Em um caso desses, se o verdadeiro filósofo fosse analisar o tiranicídio, só o que poderia dizer a um povo que tem por hábito cometê-lo é que uma série de experiências observadas por ele permite concluir que os resultados de atos como esses são frequentemente perniciosos. De qualquer maneira, como se vê, a correção é justamente pautada por um raciocínio causal. É claro que, além disso, Hume considera que os homens costumam conceber o que está próximo de maneira mais vívida do que aquilo que está distante e, assim, seria possível objetar que a vontade de se livrar de um tirano atual pode ser mais forte do que aquela de se garantir a paz futura. A isso, nosso filósofo responderia que esse é justamente um dos motivos pelos quais o ponto de vista verdadeiramente moral, que pressupõe a generalidade e a consideração pelo bem comum que vêm com a expansão da simpatia, é difícil de manter quando confrontado com sensações presentes. De qualquer maneira, parece que isso não basta para afastar a conclusão segundo a qual as correções do senso comum, além de aparentemente pautadas em conclusões causais que se referem a meios para se realizar fins que são colocados por instâncias distintas do entendimento (mesmo o entendimento "animal” de que falamos aqui), são reformas, não revoluções, e partem, como esperamos que já esteja suficientemente claro, sempre de uma situação social já dada.

Podemos retomar, agora, o caso do príncipe indiano que não acreditava na possibilidade do congelamento da água. Parece que as coisas não se dão, em uma situação como essa, do mesmo modo que aquelas que observamos no desenvolvimento 
de várias moralidades ao longo da história. Ainda que tenha chegado a uma conclusão que se mostraria enganosa com uma experiência mais ampla (e que dificilmente se deixará corrigir por simples relatos), o indiano raciocina do modo correto. Podemos afimar, então, que a teoria do conhecimento humiana tem por objetivo simplesmente indicar modos corretos de se processar a experiência que nos é dada. O advogado mencionado na Seção 1 da Investigação sobre o entendimento humano se beneficiará do estudo da filosofia não necessariamente apenas pelos conteúdos que ela terá a oferecer, mas porque aprenderá a raciocinar de modo preciso, aprendendo a separar o que é ou não relevante para a determinação de um evento e, é claro, de que modo o evento em questão se dá, sempre entendido como uma série causal. Nesse sentido, a teoria da experiência que Hume nos apresenta em sua epistemologia tem por objetivo não apenas delimitar aquilo que nos é possível conhecer, mas criar, também, uma ferramenta poderosa não apenas por conta daquilo que pode prever, mas também porque é possível empregá-la na correção daquilo que vivenciamos no que diz respeito à moral, à política, à estética etc. Quanto aos fatores que surgem de preferências de um grupo, ou de analogias fracas que levam à prevalência de uma entre várias opções igualmente úteis, só o que podemos fazer é admitir que elas podem ser explicadas e que, no fim das contas, essa própria explicação faz parte da ferramenta com a qual estamos lidando. A filosofia sempre se dará em um cenário já constituído que ela deverá simplesmente aceitar.

Devemos retomar, agora, um aspecto que já havíamos mencionado, a saber, aquele em que o filósofo se constitui, para Hume, como um ser eminentemente social. Vimos que esse ponto é estabelecido, primeiramente, na Conclusão do Livro 1 do Tratado da natureza humana e que é retomado em obras posteriores de nosso autor, tendo, aliás, sua importância aumentada consideravelmente. Se tomarmos as considerações anteriores sobre esse caráter social do filósofo e as analisarmos à luz do que acabamos de estabelecer sobre a maneira como ele deve considerar os objetos sobre os quais discorre, fica ainda mais claro que a verdadeira atividade filosófica diz respeito a um mundo do qual o filósofo é, antes de qualquer outra coisa, partícipe ${ }^{216}$. O que ele

\footnotetext{
${ }^{216}$ Esse ponto foi estabelecido tanto por Annette Baier em seu A Progress of Sentiments quanto por Donald Livingston em seu Philosophical Melancholy and Delirium. Eles chegam a essa conclusão por vias bastante distintas e, ainda que não seja o caso de dissecar as duas, faz sentido observarmos que chegamos a esse ponto por vias diferentes das trilhadas por esses dois autores.
} 
tem a dizer sobre certa lei moral ou certo texto literário depende de vivências que ele compartilha com o homem comum e, no fim das contas, o modo como ele tem de lidar com essas vivências é uma sistematização de uma modo de raciocínio que, é claro, ele também compartilha com o homem comum. A implicação não é que Hume antecipa as considerações de Merleau-Ponty, para quem o ser humano, ao contemplar os animais, os loucos e as crianças é obrigado a considerar os limites de sua própria razão ${ }^{217}$. Os objetos ainda são, para Hume, apenas objetos (ainda que não sejam necessariamente existentes de modo externo à mente), afinal, e crianças e loucos não são vistos por ele como espelhos, mas como algo oposto àquilo que é o homem em seu estado normal ${ }^{218}$. O que nosso filósofo pretende estabelecer é que nosso conhecimento é limitado pela nossa vivência no mundo e na sociedade, mas, evidentemente, existe, para ele, um modelo de homem que, raciocinando de acordo com o que lhe recomenda a natureza, é não apenas preferível, mas o modo correto. Trata-se, é claro, do homem sensato, que “proporciona sua crença à evidência” e, além disso, julga do modo apropriado as instâncias de que participa. De certa maneira, podemos dizer que, ao mesmo tempo em que se dirige a esse tipo de homem, Hume, ao voltar-se, depois do Tratado, ao leitor comum, pretende, de certo modo, contribuir para formá-lo. O modo de se processar as experiências do leitor, afinal, é mostrado como uma versão corrigida da razão que ele já empregava e, quanto às próprias experiências, podemos dizer que já estão dadas e que, quando não for esse o caso, serão, ainda assim relatadas (o que, salvo no caso de relatos que não merecem confiança, não é lá muito diferente $)^{219}$.

217 Essa foi a principal tese exposta por Merleau-Ponty em conferência via rádio que se tornaria o Capítulo IV de Conversas - 1948.

${ }^{218}$ Isso fica estabelecido, por exemplo, na Seção 2 da Investigação sobre o entendimento humano, em que Hume afirma que, a não ser em caso de doença ou de loucura, vistas como algo simplesmente indesejável e inaceitável, as impressões e as ideias nunca são confundidas, por conta de suas vivacidades bastante diferentes.

219 Concordamos, nesse ponto, com Adam Potkay, que defende, ao longo de seu The Passion for Happiness, que esse é um dos principais propósitos da filosofia de Hume. Potkay também afirma, não sem razão, que esse é, também, o grande objetivo da filosofia de Samuel Johnson. Boa parte do livro desse comentador procura mostrar de que modo os textos de Johnson constituem um elogio da sociabilidade e, nesse sentido, não seria absurdo considerar as filosofias de Hume e de Johnson mais próximas do que especialmente este último gostaria de admitir. Ainda que concordemos que o elogio da sociabilidade proposto por Johnson se assemelha de certa forma ao de Hume (especialmente quando 
O fato de estarmos falando em uma oferta, por parte do filósofo, de versão corrigida das crenças do vulgo implica, é claro, que a atividade filosófica em sua forma verdadeira não se limitará ao endosso de todos os preconceitos já oferecidos pela vida comum. Não podemos simplesmente deixar de lado passagens em que Hume simplesmente fala sobre a necessidade de se abandonar qualquer preconceito para se atingir um julgamento correto. A mais famosa delas aparece no ensaio "Of the Standard of Taste":

Mas para que o crítico se torne mais plenamente habilitado a executar essa tarefa [a de avaliar os méritos de uma obra que lhe é exibida], ele deve conservar sua mente livro de todo preconceito, e não deve permitir que nada adentre sua consideração, além do próprio objeto que é submetido ao seu exame ${ }^{220}$. (HUME 37, p. 239)

Poderíamos simplesmente objetar que essa tese é oferecida em um texto sobre estética e, assim, diz respeito a um tema muito particular. Infelizmente, as coisas não são tão simples. Isso porque, tanto em estética (como se vê no próprio “Of the Standard of Taste”) quanto em moral, Hume é um autor que considera que certas características observadas em um dado objeto se predispõem a afetar a mente de maneiras determinadas. Algo que parece apropriado ao uso para o qual foi concebido, por exemplo, tende ser visto como belo. Por isso é uma casa que parece apropriada para a habitação tende a ser considerada bonita, do mesmo modo que um cavalo cuja constituição o fará ser veloz. Do mesmo modo, se o bem dos outros fosse indiferente para nós, as virtudes sociais seriam algo que não provoca qualquer sentimento de aprovação e, portanto, não seriam consideradas virtudes. Por isso é que Hume considera que “Apenas alguém acostumado a ver, a examinar e a pesar as várias performances admiradas em diferentes épocas e nações é que pode avaliar os méritos de um trabalho

consideramos textos como Rasselas), e ainda que admitamos que Johnson também tem entre suas principais preocupações a formação de pessoas sensatas, parece que ele e Hume discordariam em vários aspectos sobre o que é exatamente um homem sensato, mesmo que consideremos os aspectos em que Johnson pode ter compreendido mal a filosofia humiana.

220 "But to enable a critic the more fully to execute this undertaking, he must preserve his mind free from all prejudice, and allow nothing to enter into his consideration, but the very object which is submitted to his examination”. 
exibido a ele ${ }^{221 »}$ (HUME 37, p. 238). E nesse sentido, pode-se dizer que o contato com as obras de “diferentes épocas e nações” é simplesmente uma ampliação da experiência. Esse processo permite que o filósofo avalie quais são as características que tendem a resultar em certos efeitos. O mesmo pode ser aplicado às diferenças entre as morais de diferentes povos. No Diálogo que encerra a segunda Investigação, Hume deixa claro que, ainda que haja espaço para diferenças de costumes (como há espaço para diferenças de moda nas artes de períodos ou lugares diversos), nem todas elas são completamente relevantes.

Podemos, então, afirmar que um filósofo, desse modo, age como um participante da experiência, mas não necessariamente da experiência restrita que é característica de seu próprio tempo ou de seu próprio povo. Ele é capaz de reconhecer esses aspectos mais específicos, é claro, e é capaz de aceitá-los em certa medida. Ocorre, porém, que há situações em que esses preconceitos particulares, que se devem, como vimos, a analogias fracas da imaginação, podem impedir uma avaliação precisa daquilo que realmente define aspectos importantes da avaliação, como as características que fazem com que uma obra provoque o efeito desejado, ou como a consideração pelo bem público que, resultante da simpatia expandida (ou da benevolência expandida), permite o julgamento verdadeiramente moral. É claro que é possível que, ocasionalmente, esses preconceitos sejam, por assim dizer, inofensivos, ou que simplesmente determinem a escolha de um entre vários meios possíveis para se atingir a satisfação de uma necessidade estética ou moral, mas esse nem sempre é o caso. Assim, boa parte da correção que o verdadeiro filósofo deve realizar diz respeito justamente à identificação de aspectos que não têm a ver com os verdadeiros fundamentos que nos levam a aprovar ou a censurar certas características. Mesmo no Livro 1 do Tratado isso já estava indicado, quando, ao tratar das causas gerais, Hume afirmava que é preciso separar aquilo que realmente contribui para a ocorrência de um efeito daquilo que pode aparecer junto com a causa, mas não faz parte dela.

Concluímos, a partir disso, que o filósofo, ainda que seja um participante da experiência, não se deve deixar limitar ao quinhão dela com que o vulgo muitas vezes se contenta. É claro que características particulares de um povo, por exemplo, podem ser

221 "One accustomed to see, and examine, and weigh the several performances, admired in different ages and nations, can alone rate the merits of a work exhibited to his view". 
aprovadas em sua particularidade simplesmente porque foram um meio escolhido para dar conta de um problema. É claro, também, que situações análogas podem ser imaginadas no que diz respeito à arte. Ainda assim, não podemos perder de vista que a vida humana se dá de forma dinâmica e, futuramente, uma mesma solução pode, por vários fatores diferentes, deixar de provocar o efeito desejado. Nesse momento, certamente o filósofo deverá se propor a considerar, com base tanto na natureza humana quanto nas circunstâncias, soluções apropriadas para o problema que houver irrompido. Mesmo assim, ao tratar seja de virtudes que parecem ter estatuto universal, como a benevolência, seja de instituições particulares que se dão em certos grupos e são efetivamente apropriadas para a promoção do bem público, a explicação do filósofo será, ela mesma, uma justificação, já que tratará justamente de explicar por que uma dada instituição é apropriada para promover aquela que é sua finalidade. Fica mantida, em todo caso, a correção do senso comum como reforma, não como revolução, bem como a posição do filósofo como partícipe de uma experiência, mas essa experiência pode apresentar discrepâncias com relação à experiência do vulgo, ainda que um filósofo que busque atingi-lo deva certamente tentar ampliar a experiência de seus leitores, como veremos a seguir.

\section{O papel da história}

Aquilo que dissemos acerca do papel dos exemplos na Investigação sobre os princípios da moral, bem como o que defendemos acerca do que caráter participativo da experiência e da importância que ele tem para a correção do senso comum, constitui uma oportunidade interessante para que possamos verificar qual é o estatuto da história no projeto filosófico de Hume. Estamos lidando, afinal, com um filósofo que, em seu tempo, conseguiu fama principalmente por uma História da Inglaterra bastante volumosa, mais extensa do que qualquer outro de seus escritos. Ainda assim, a História é geralmente deixada de lado pela maioria dos comentadores, que geralmente não pensam em explorar possíveis vínculos entre esse texto e aqueles em que Hume estabelece de maneira detalhada suas doutrinas filosóficas ${ }^{222}$.

\footnotetext{
${ }^{222}$ Uma exceção realmente notável pode ser encontrada no livro Death and Character, de Annette Baier. A primeira parte dessa obra é justamente dedicada a explorar consequências filosóficas que podem ser extraídas da História da Inglaterra, principalmente no que diz respeito à filosofia humiana do eu. Donald
} 
A primeira sugestão que encontramos entre uma possível relação entre a história e a filosofia humiana está na Introdução do Tratado, em que é feita no último parágrafo, como já vimos, a afirmação de que, como não é possível, por assim dizer, colocar a natureza humana no laboratório, devemos construir a ciência do homem com base em uma observação cuidadosa da vida humana, "tal como ela aparece no curso comum do mundo”. Até aí, nada de novo. Isso explica, ao menos em parte, o procedimento adotado por Hume ao longo de toda a sua obra de estreia. O Livro 1, portanto, se ocupa de derivar leis da observação do modo como efetivamente observamos que o entendimento funciona. O Livro 2, é claro, parte de uma observação direta do modo como as paixões se apresentam. O Livro 3, por fim, investe justamente em condições dadas, como a aprovação que oferecemos a certas características e nossa aceitação de conceitos como propriedade e governo, considerando tais fatos como pontos de partida para uma explicação baseada em características humanas já descobertas nos livros anteriores. Além disso, a ideia de que uma ciência do homem só é possível pela observação da vida aparece inegavelmente em todos os textos filosóficos de Hume. A História natural da religião, por exemplo, é baseada em um número imenso de observações desse tipo. Os Diálogos sobre a religião natural, além de serem escritos de modo a reproduzir um debate de maneira realista, não desmerecem em nada a razão experimental estabelecida em textos humianos exteriores, mas procura justamente mostrar as limitações que ela apresenta quando aplicada ao tema da existência de Deus. A Investigação sobre os princípios da moral, em que Hume faz uso bastante evidente de exemplos históricos e cotidianos, parece confirmar, também ela, que a observação da vida é um fator essencial para a ciência que nosso filósofo pretendeu construir. Isso permite, sem a menor dúvida, que afirmemos que Hume via na história um imenso laboratório.

Parece, entretanto, que esse aspecto não é o único pelo qual nosso filósofo considera a história algo importante. Isso fica evidente em um ensaio intitulado "Of the Study of History” 223 , no qual Hume afirma que “As vantagens encontradas na história

Livingston, em seu Philosophical Melancholy and Delirium, também mostra uma enorme disposição em verificar de que modo a história escrita por Hume permite que atiremos mais luzes a seus textos mais propriamente filosóficos.

223 Annette Baier sugere que o motivo pelo qual Hume suprimiu esse ensaio teria sido o fato de ele considerar que, em sua sugestão de que as mulheres leiam textos históricos em vez de novelas (BAIER 3, p. 5), o tratamento do "belo sexo" oferecido por ele havia sido um tanto condescendente. Pode ter sido o 
parecem ser de três tipos, já que ela diverte a imaginação, melhora o entendimento e fortalece a virtude ${ }^{224 » .}$ Quanto ao divertimento, não é difícil entender o que nosso autor afirma: a história como que nos transporta às eras mais remotas e permite que observemos a sociedade quando ela ainda engatinhava. Com relação ao entendimento, o que Hume quer dizer é que a história é uma parte do conhecimento e, é claro, daquilo que chamamos erudição. Por fim, com relação à virtude, a história parece ser mais vantajosa que a poesia, e mesmo que a filosofia. Poetas, afinal, por se endereçarem à paixão, podem pintar a virtude com as cores mais encantadoras, mas, por vezes, tornamse cúmplices do vício. Os filósofos, como sabemos, frequentemente se perdem nas sutilezas de suas especulações ou, em alguns casos, chegam a negar a realidade das distinções morais $^{225}$. Os historiadores, por outro lado, sempre se mostram amigos da virtude (HUME 37, pp. 565-7).

Essa observação de Hume sobre a possibilidade de o filósofo se perder em suas especulações parece curiosa. Nosso autor a atribui ao fato de filósofo, ao contemplar caracteres e maneiras trancado em seu gabinete, observar os objetos de maneira bastante abstrata, de modo que os sentimentos que naturalmente o acometeriam não operam da maneira apropriada. A história ofereceria, então, o meio termo apropriado entre esse ponto de vista demasiadamente distante e outro em que, imersos em uma vida meramente ativa, estamos sempre presos a nossos próprios interesses. Esse é um ponto caso, ainda mais se levarmos em conta o fato de Hume ter suprimido, também, “Of Essay Writing” e "Of Love and Marriage”. Este último pode ser considerado uma verdadeira sátira às mulheres e, quanto ao primeiro, ainda que reconheça que as mulheres ocupam um lugar proeminente na vida social, parece tratálas apenas como figuras proeminentes na vida social. Em alguns momentos de sua obra, nosso filósofo parece, efetivamente, considerar as mulheres como seres que devem simplesmente, por meio de sua delicadeza, colaborar para que os homens se civilizem. Ainda assim, não podemos ignorar o fato de Hume ter suprimido ensaios que não traziam qualquer conteúdo ofensivo para as mulheres, entre eles "Of Suicide” e “Of The Middle Station of Life”. Devemos observar, também, que Hume afirmou que havia excluído alguns ensaios simplesmente por considerá-los fúteis. Assim, já que Baier não citou sua fonte ao afirmar que Hume suprimiu o ensaio sobre o estudo da história por conta do modo como ele considera as mulheres, não podemos tomar a posição de Baier como definitivamente correta.

224 "The advantages found in history seem to be of three kinds, as it amuses the fancy, as it improves the understanding, and as it strenghtens virtue”.

225 Nesse ponto, fica bastante evidente para o leitor a "alfinetada” que Hume desfere a autores como Hobbes e Mandeville. 
que não entra em conflito com o que vimos afirmando sobre a atividade filosófica em sua forma verdadeira. Como já tínhamos observado, Hume pretende que sua ciência do homem deva justamente recorrer o tempo todo o à história e à vida cotidiana para que não se torne apenas um monte de divagações bastante fantasiosas. A leitura da história, aliás, é particularmente importante porque, de certo modo, amplia o mundo de que o verdadeiro filósofo participa:

E de fato, se considerarmos a curta duração da vida humana e nosso conhecimento limitado até mesmo do que se passa em nosso próprio tempo, devemos nos conscientizar de que deveríamos ser sempre crianças no que confere ao nosso entendimento se não fosse por essa invenção, que estende nossa experiência a todas as épocas passadas e às nações mais distantes, fazendo com que elas contribuam tanto para o aumento de nossa sabedoria quanto se estivessem realmente sob nossa observação. De um homem familiarizado com a história, podese dizer, de certo modo, que viveu desde o início do mundo, e que fez contínuas adições a seu estoque de conhecimento em cada século ${ }^{226}$. (HUME 37, pp. 566-7)

Parece, então, que, sendo o verdadeiro filósofo alguém que recorre constantemente à história, ela pode ser vista por ele como uma ampliação das experiências que ele pode realizar partindo apenas da vida humana presenciada in vivo. Nesse sentido, ele se compara, como já vimos, ao crítico que está verdadeiramente habilitado a julgar o valor de uma obra de arte. E como domina o modo correto de raciocinar, ele pode estender suas investigações filosóficas muito mais do que lhe seria

\footnotetext{
226 "And indeed, if we consider the shortness of human life, and our limited knowledge, even of what passes in our own time, we must be sensible that we should be for ever children in understanding, were it not for this invention, which extends our experience to all past ages, and to the most distant nations; making them contribute as much to our improvement in wisdom, as IF they had actually lain under our observation. A man acquainted with history may, in some respect, be said to have lived from the beginning of the world, and to have been making continual additions to his stock of knowledge in every century".
} 
permitido pela simples observação não educada da vida cotidiana e de eventos que lhe são contemporâneos ${ }^{227}$.

A visão da história como um meio apropriado, é verdade, não está completamente livre de problemas. É compreensível que Hume não considerasse apropriadas histórias como a de um Clarendon, que estava bastante envolvido em sua filiação "partidária”, o que certamente interferiu, digamos, em seu relato sobre a rebelião de 1745. Que os historiadores devem evitar falar sobre aquilo com que têm envolvimento tão direto é algo ditado pelo bom senso, e nosso autor, ao termiaté por terminar sua História da Inglaterra relatando os eventos de 1688 (muito anteriores, portanto, ao período em que escreve), parece concordar com isso. Em nenhum momento, porém, ele parece ver como problemático o fato de que não temos como precisar o envolvimento de alguns historiadores antigos nos eventos que eles narram, ainda que a suposição de que esse envolvimento possa ter existido ao menos em alguns casos não seja completamente improvável. De qualquer maneira, parece que a história, do modo como Hume a toma, mais do que apenas um laboratório ou algo que se presta à observação, é realmente um modo de aumentar a experiência de que o filósofo participa. Se o relato é considerado confiável, é como se o leitor de um texto histórico conhecesse o que há de relevante nas situações narradas e, em certo sentido, pudesse extrair consequências desses eventos como se efetivamente tivesse estado presente quando ocorreram, mas sem adotar a filiação partidária que poderia prejudicar seu juízo. É quase desnecessário, portanto, enfatizarmos que o verdadeiro filósofo poderá empregar em sua análise também as experiências que lhe forem oferecidas por relatos históricos. Na verdade, esse é um procedimento com que Hume parece bastante à vontade ao longo de toda a sua segunda Investigação, bem como em sua História

\footnotetext{
${ }^{227}$ Pode ser interessante, então, lembrar o argumento oferecido no Tratado para garantir que o testemunho histórico nos afeta de maneira vivaz, ainda que diga respeito a algo que, em tese, foi repetido inúmeras vezes à medida em que mais e mais cópias de um mesmo relato eram feitas, o que poderia fazer com que a transição de nossas mentes até o fato original fosse bastante complicada. Hume resolve essa dificuldade afirmando uma semelhança praticamente exata entre uma cópia e outra, o que facilitaria a transição e evitaria a perda de vivacidade.
} 
natural da religião, em que as teses sobre as religiões populares são sempre corroboradas por uma imensidão de exemplos ${ }^{228}$.

Além disso, podemos dizer sem hesitação que a História da Inglaterra oferece um terreno bastante farto para que Hume possa confirmar algumas de suas teses. Não fica claro, é verdade, se a História teria sido uma fonte de observações a partir da qual ele teria tirado certas conclusões ou se elas serviriam como um modo de corroborar teses que já estariam determinadas a partir de textos anteriores, mas, de qualquer modo, é clara a preocupação de nosso filósofo em mostrar, em certos momentos, que certos aspectos de sua filosofia moral podem ser comprovados por meio de relatos históricos. Alfred o grande, por exemplo, tem entre seus méritos o fato de possivelmente ter sido o

${ }^{228}$ Talvez uma concepção da experiência como algo em que se participa possa justificar, ao menos parcialmente, a tolerância maior que Hume apresenta, na História natural da religião, com relação ao politeísmo. Por não procurar instaurar um regime moral pautado não no desenvolvimento natural da simpatia, mas em princípios extraterrenos e, no limite, praticamente ininteligíveis, tais religiões até poderiam ser vistas, simplesmente, como parte das tradições de um povo. Ainda assim, Hume não parece exatamente condescendente, por exemplo, com os druidas, que, como vimos, ele critica brutalmente no início de sua História da Inglaterra. Eles são apresentados como uma casta que impõe um verdadeiro reinado de terror, e fica claro que só podem fazê-lo porque seus seguidores são um povo ignorante e indolente. Parece que o propósito de Hume ao longo da História natural da religião é, no fim das contas, minar as religiões populares monoteístas mostrando que, no fim das contas, elas operam sobre os mesmos fundamentos que regem as politeístas, as quais já eram certamente, para os leitores que Hume tinha em vista, consideradas simplesmente indefensáveis. Nesse aspecto, tendemos a concordar com o artigo já mencionado de Lívia Guimarães. Gostaríamos apenas de adicionar que, ao tratar de religiões politeístas, Hume faz questão de mostrar que, ainda que não resultem sempre em absurdos morais, não são justificáveis por experiência alguma, mas resultam daquela propensão a atribuir propriedades humanas às coisas inanimadas, a qual ele já havia criticado ao tratar da filosofia antiga. E como no politeísmo se considera normalmente que os deuses deixam aspectos morais e cotidianos à escolha dos mortais, não seria possível afirmar que a "correção" dessas instituições religiosas pela experiência seria essencial para a manutenção das civilizações em que ela ocorre. Portanto, ainda que não seja o caso de criticar toda uma civilização por conta de seu politeísmo, certamente seria possível reformá-la para que pudesse existir, sem deixar de ser ela mesma, "alterada” nesse sentido. Nesse ponto, rompemos com a leitura que Donald Livingston faz desse tema, já que ele considera Hume muito mais otimista com relação ao politeísmo do que nossa leitura poderia permitir. Tanto a intenção inicial da História natural da religião, que pensamos implicar o uso do politeísmo como forma de desmantelar o teísmo, quanto o tom do texto e o tratamento geral que Hume faz do tema nos impedem de acreditar que, ainda que ele considere as instituições politeístas inofensivas se comparadas às teístas, ele seria realmente simpático a alguma forma de politeísmo. 
primeiro instituidor da common law. Se pensarmos que essa instância do direito inglês é basicamente consuetudinária e que está em voga, de forma evidentemente mais refinada, até nossos dias (e, portanto, vigorava na época de Hume), parece evidente que a observação de nosso autor a esse respeito, ainda que aparentemente casual, é bastante significativa. Até porque Hume atribui o bom funcionamento das leis de Alfred à sua similaridade com as leis saxônicas em voga na época e considera que esse príncipe teria se contentado em reformar, estender e executar instituições que já estavam prontas (HUME 40 vol. 1, pp. 78-9), o que, como já vimos, está em plena conformidade com o que nosso autor consideraria uma maneira verdadeiramente apropriada de lidar com um problema desse tipo. Convém lembrarmos, ainda, que Hume atribui a Alfred o caráter mais perfeito que se poderia imaginar, repleto das maiores virtudes, e isso é atribuído a uma disposição igualmente grande para a atividade e para o estudo, o que parece confirmar a máxima segundo a qual a melhor vida possível é aquela em que há, como já vimos, igual dedicação à vida social, aos negócios e à filosofia.

O tratamento que a religião recebe na História da Inglaterra também parece refletir teses importantes presentes em outros textos de Hume. O volume III, por exemplo, oferece uma confirmação importante daquilo que havia sido afirmado sobre a intolerância do teísmo na História natural da religião. A perseguição de católicos a protestantes confirma esse fato e, é claro, o modo como estes últimos são tomados da maior alacridade quando são conduzidos às fogueiras parece bastante significativo. Os dois lados da contenda são apresentados como igualmente convictos de que não devem tolerar o inimigo. A única passagem em que a própria tolerância é discutida de maneira mais detalhada se dá em um contexto eminentemente político, já no final do volume, em que dois conselheiros da rainha Maria defendem posições contrárias sobre esse tema (evidentemente, um é favorável à tolerância e o outro, contrário a ela), mas levando em conta exclusivamente o impacto político que decorreria dessa prática. Em momento algum a tolerância é apresentada, ao longo dessa disputa, como algo que deve ser discutido à luz da própria doutrina papista que era esposada por Maria. Do mesmo modo, Cromwell, de quem Hume se ocupa em parte considerável dos volumes que cobrem a história do período mais próximo ao seu, é apresentado não necessariamente como alguém que não acredita nos valores puritanos que prega, mas certamente como alguém que, acreditando ou não nessas doutrinas, não hesita em fazer delas um instrumento político que ele manipula com grande habilidade. Isso parece reforçar o 
descolamento de religião e moral que nosso autor propõe de maneira explícita em quatro outros textos, que incluem os Diálogos sobre a religião natural, a História natural da religião e a Seção 11 da Investigação sobre o entendimento humano, já mencionados no que diz respeito a esse tema, e a "Conclusão” da Investigação sobre os princípios da moral, em que Hume faz uma crítica bastante ácida das virtudes monásticas, consideradas por ele como perniciosas para a sociedade. Isso não porque os partidários de doutrinas religiosas sejam representados nessas obras como necessariamente viciosos, mas porque a religião pode oferecer algo como um instrumento para que até os piores vícios sejam exercidos sem grandes preocupações, já que sempre poderão ser perdoados. Ainda assim, não podemos deixar de notar que a preocupação tanto de Maria quanto de Cromwell não era exatamente apresentar a religião como um guia apropriado de conduta a cidadãos conscientes, mas impô-la com motivos políticos ou, em alguns casos, usá-la como uma ferramenta que seria útil para um fim muito distinto da formação moral.

Essas considerações devem bastar para que não restem dúvidas de que a história é, para Hume, um instrumento bastante apropriado para que o filósofo possa ampliar a experiência de que participa e, desse modo, garantir amplitude e correção maiores para seus raciocínios. Faltou extrair as conclusões apropriadas da observação de que, em "Of the Study of History", ela é apresentada como algo que as mulheres deveriam ler ao invés de novelas. Evidentemente, não haveria motivo para nos determos, agora, no que isso permite dizer com respeito à visão que Hume teria da mulher, já que isso fugiria bastante aos nossos propósitos. Em vez disso, desviamos nosso olhar para o fato de que não podemos nos esquecer de que essa é a recomendação de um filósofo homem que, como acabamos de explicar, acreditava que boa parte do material com que ele podia contar em seus raciocínios provinha exatamente dos relatos históricos. Assim, parece inegável que o estudo da história não é algo restrito ao filósofo, mas também a um público mais amplo que não pode ser restrito às mulheres. O público da história, no fim das contas, é composto por todos aqueles que procuram uma diversão que não apenas está longe de ser prejudicial como, além disso, pode oferecer as três vantagens que, como já mostramos, Hume vê nesse tipo de texto. Portanto, não é incorreto afirmarmos que nosso autor considera que ele também pensa no homem comum quando declara que o leitor de um texto histórico não apenas se divertirá como, além disso, aumentará seu conhecimento e fortalecerá sua virtude. Parece, então, que as funções da história não são 
tão diferentes daquelas que Hume atribui à “filosofia fácil” de que fala na Seção 1 da primeira Investigação. E mesmo uma filosofia que pretenda conciliar esses aspectos “fáceis” com outros daquela “filosofia mais abstrusa” não poderá abrir mão de relatos históricos, simplesmente porque é deles, bem como da observação da vida humana presente, que ela tira os experimentos de que tanto necessita.

Isso fica evidente, também, em diversos dos Ensaios e, como não poderia deixar de ser, nas duas investigações. Que esse é o caso da “filosofia fácil” já deve estar, a esta altura, bem estabelecido. Quanto à “difícil e abstrusa”, não seria exagero dizer que a "geografia mental” praticada por Hume depende de uma observação de eventos que se dão no tempo e, portanto, o que nosso filósofo pretende na versão revisada de sua teoria do conhecimento é, de certo modo, uma explicação de como o desenvolvimento da mente que tem, ela própria, um modo de proceder essencialmente histórico. Essa consideração certamente ajuda a explicar de que modo Hume buscou efetuar a conciliação das diferentes espécies de filosofia. Parece, então, que, nos textos posteriores ao Tratado da natureza humana, nosso autor considerou que a instauração de um modelo que reconstroi de maneira histórica a experiência de que tanto filósofos quanto homens comuns participam seria um bom modo de possibilitar que a atividade filosófica, além de ser assunto de catedráticos, passasse a beneficiar diretamente também o homem comum. 


\section{CONCLUSÃo}

A esta altura, dois aspectos do modo como Hume dispôs suas considerações sobre a natureza da verdadeira atividade filosófica devem estar evidentes. O primeiro é que ele certamente mostrou grande preocupação com esse tema, ao cunhar textos em que a própria filosofia era o tema principal. O segundo é que o recurso a esses textos, ainda que seja de grande importância para a compreensão do que nosso autor considera que é a filosofia, não é suficiente. A filosofia é, para Hume, um fenômeno que tem sua raiz em princípios da natureza humana, mas que, exatamente por isso, só pode ser inteiramente compreendido quando visto como parte da vivência social. Não é possível simplesmente esperar que o uso da razão demonstrativa, vista por tantos autores como capaz de explicar todas as coisas, possa estabelecer a boa filosofia e, além disso, definila simplesmente como o próprio uso dessa razão clássica quando aplicada a certos temas.

Na primeira parte deste trabalho, pudemos observar justamente o que ocorre quando a filosofia procede dessa maneira. A razão, voltada para si mesma, subverte-se e passa a se apresentar como destituída de confiabilidade. Além disso, essa razão simplesmente não é, para Hume, aquilo de que fazemos uso para conhecer o mundo que se nos apresenta. Quando é esse tipo de conhecimento que está em jogo, a única coisa com que podemos contar é um certo tipo de propensão que nos acometerá quando observarmos certos tipos de conjunções. E mesmo essas conjunções, para que possam ter algum significado, exigem a simples aceitação de aparições que, como vimos, são apenas ficções engendradas pela imaginação. A recusa em simplesmente aceitar as ficções que nos são impostas pela natureza equivaleria, assim, à tentação de abraçar princípios que não apenas são impossíveis de fundamentar, como, além disso, contrariam toda experiência, de modo que terminam por constituir a raiz daquilo que, ao longo deste trabalho, temos chamado, seguindo a sugestão do próprio Hume, falsa filosofia. São esses os princípios responsáveis por doutrinas como a das qualidades ocultas e a da dupla existência, bem como pelas morais do amor próprio. São esses, também, os motores que estão na origem de sistemas que, por ignorarem completamente a experiência, que mostra de maneira bastante contundente quais são os princípios da natureza humana efetivamente envolvidos na atividade filosófica, buscam 
explicar todo o universo a partir de uma razão que nem ao menos é apropriada para investigá-lo. Como vimos, essas filosofias operam completamente isoladas do senso comum e do próprio mundo percebido e, por conta disso, não dizem respeito a nada senão a universos fantásticos criados por seus partidários. A dupla existência, por exemplo, não é, para Hume, apenas uma explicação falha deste mundo, mas algo como uma descrição de um universo que simplesmente não nos diz respeito. Isso não porque é evidente que não há objetos que estão "por trás” de nossas percepções, mas porque a filosofia simplesmente não tem como se ocupar desse tipo de problema (de modo que esse tipo de questão não pode nem mesmo ser considerada, do ponto de vista estritamente filosófico, um problema).

O ceticismo total, associado por Hume ao pirronismo, também não se mostra uma saída apropriada. Como já vimos, os únicos resultados que podemos esperar dele são um isolamento ainda maior do que o dos falsos filósofos e uma insegurança completa que, no fim das contas, atira seu praticante à mais profunda melancolia. É nesse ponto, como vimos, que nosso autor considera seriamente a possibilidade de atirar todos os seus livros ao fogo e abandonar completamente uma vida que se caracterize pela dedicação à filosofia. Felizmente, a natureza vem em sua salvação, obrigando-o a aceitar certas ficções que não poderão jamais ser recusadas. Isso não apenas por conta do desespero que decorreria de uma tal recusa, mas, também, porque é impossível a quem quer que seja, ao abandonar seu gabinete, sustentar posturas completamente céticas. Desse modo, Hume, ainda que continue a defender princípios relacionados a essa escola, tratará de fazê-lo de modo bastante diferente, aceitando as propensões inescapáveis impostas pela natureza. Ser-lhe-á impossível, então, recusar a existência contínua e independente daquilo que denominamos objetos externos e, é claro, será impossível recusar, também, a constância da ordem da natureza e as relações causais. No fim da contas, não importa se é possível justificar racionalmente esses aspectos, já que somos irresistivelmente compelidos a lidar com eles o tempo todo. Assim, nosso filósofo permanecerá cético, mas esse ceticismo dirá mais respeito a uma delimitação daquilo que é acessível a nosso entendimento do que a uma simples recusa de toda e qualquer percepção nos seja oferecida. Há crenças que, racionalmente justificadas ou não, simplesmente não temos a possibilidade de recusar, e é na sistematização delas que consiste a atividade do verdadeiro filósofo. 
No capítulo anterior, vimos que isso implica a ideia de que o filósofo atua o tempo todo como participante da experiência, além de observar as condições segundo as quais isso ocorre. Isso tem uma importância gigantesca quando observamos a mudança ocorrida na opinião de Hume acerca do público que a filosofia deve atingir. Como no Tratado a condição eminentemente social do filósofo era reconhecida, não era preciso mostrar os experimentos e as observações realizados por ele senão em um linguajar bastante abstrato, que buscava atingir principalmente os eruditos. As coisas não poderiam permanecer dessa maneira quando nosso autor passasse a tentar alcançar um público mais amplo. E se ele se recusou a tornar-se um “filósofo fácil”, era essencial encontrar um modo de expressão que permitisse a preservação do rigor e o caráter de explicação experimental de sua filosofia sem que isso a tornasse inacessível ao leitor que simplesmente tinha interesse em estudá-la para divertir-se (e ter mais meios de divertir outros em situações sociais), melhorar seu entendimento e fortalecer sua virtude. Não é por acaso que Hume passou, a partir daí, a escrever em formato mais ensaístico, ou que ele tenha se interessado em escrever uma História da Inglaterra simplesmente colossal. Esse formato teria permitido a ele realizar experimentos que explicassem os princípios que ele defendia e, ao mesmo tempo, recomendar os aspectos da vida comum que suas análises mostrassem ser virtuosos e criticar aqueles que poderiam ser causa de danos consideráveis. O tempo todo, palavras como benevolência e beleza se referem a palavras que são cunhadas de modo a expressar, desde a sua origem, características louváveis, em um procedimento que, além de explicar a origem de tais virtudes e apresentá-las com todas as circunstâncias que as determinam, de modo a mostrar qual é a concepção exata delas, termina por implicar não só uma explicação do que é esta ou aquela virtude, mas também seu elogio. Do mesmo modo, apresentar o método correto pelo qual podemos conhecer o mundo não é apenas expor certos princípios do entendimento, é recomendar o uso de ferramentas que são verdadeiramente apropriadas para a obtenção de conclusões sobre o mundo que, se não podem ser consideradas necessariamente portadoras de uma verdade, certamente são vistas por Hume como satisfatórias e suficientes.

Parece inegável, então, que a verdadeira filosofia traz àqueles que a levam a sério uma melhoria do entendimento. Além disso, ela parece capaz de educar o gosto de modo a formar pessoas com sentimentos apropriados no que concerne a virtude e a arte. Resta ver se há propósitos maiores que nosso autor tinha em vista. Esse é um ponto que 
podemos começar a investigar lembrando que, em carta a Hutcheson, ele havia afirmado que considerações sobre uma eventual finalidade do homem estavam distantes de seus propósitos. Para o verdadeiro estudioso da natureza humana, então, não importa saber se o homem é "feito para a felicidade ou para a virtude”.

Ainda assim, em um quarteto de ensaios em que trata de escolas filosóficas "que se formam naturalmente no mundo", ele as apresenta como linhas de pensamento que dizem respeito "à vida humana e à felicidade”. Esses ensaios são nomeados a partir de escolas que realmente existiram; são intitulados “The Epicurean”, “The Stoic”, “The Platonist” e "The Sceptic”. Ainda assim, Hume não propõe nesses textos uma crítica dessas escolas, simplesmente nomeia as tais "seitas" que se formam naturalmente conforme as escolas a que elas mais se assemelham (HUME 37, p. 138 n). O epicurista é assemelhado ao homem que rejeita a filosofia e se entrega completamente à vida social e ao prazer. O estoico, por sua vez, dedica-se ao cultivo da virtude expressa por meio da ação, que redunda em patriotismo e em uma benevolência que guarda algo de piedade pelos outros homens, considerados como inferiores, quase animais, já que não se preocupam em desenvolver as artes ou as virtudes sociais mais austeras. O platônico, por sua vez, desdenha do estoico por considerar que ele não apenas deixa de contemplar alguma forma de divindade que deveria ser o único juiz de nossas ações como, além disso, parece pautar suas ações por um desejo patológico de aplauso.

Quanto chegamos ao ensaio sobre o cético, nossas primeiras impressões são enganadoras. Em primeiro lugar, ele é o único do quarteto que não traz uma nota de rodapé explicando a que tipo de homem ele se refere. O epicurista havia sido apresentado como "o homem de elegância e prazer"; o estoico, como "o homem de ação e virtude” e o platônico, como “o homem de contemplação e devoção filosófica”. Parece que, ao lermos os ensaios referentes a essas três “escolas”, somos remetidos a três estilos de vida que, como já vimos, Hume considera que devem estar combinados para que a felicidade seja a maior possível. Seria de se esperar, então, que o cético pudesse mostrar algum caminho que conciliasse esses aspectos, ou que sua recusa das três escolas precedentes se desse em termos bastante humianos. Num primeiro momento, parece mesmo ser esse o caso. O cético inicia sua apresentação com uma tirada debochada em que acusa os outros filósofos de simplesmente aderir a um princípio preferido, e essa parece mesmo uma observação que Hume não hesitaria em fazer. Além disso, o cético desconfia, principalmente, das observações dos filósofos 
sobre a vida humana. Ora, Hume desconfia das morais do amor próprio (um exemplo emblemático de “princípio favorito”), das religiões “filosofizadas” e assim por diante. Finalmente, o cético considera felizes paixões que não são violentas, paixões benignas e sociais e paixões alegres e esperançosas (HUME 37, p. 167). Esses tópicos parecem estar de acordo com a filosofia humiana de maneira geral. Do mesmo modo, a capacidade que o hábito tem de reformar as afecções também parece que seria aceita por nosso autor (HUME 37, p. 171). Entretanto, essas não são as únicas considerações do cético com relação à própria atividade filosófica. O cético do ensaio a rejeita completamente, por considerar que, se ela estiver distante da vida comum, não será capaz de se mostrar verdadeiramente influente e, se estiver próxima dela, não será necessária, já que se limitará a apresentar princípios aos quais os homens podem chegar sem se envolver em debates filosóficos. Além disso, nos casos em que a filosofia realmente gera benefícios, eles sempre estão acompanhados por novos problemas que não estavam lá antes da reflexão filosófica (HUME 37, pp. 173-6). Apenas duas considerações filosóficas são admitidas como válidas pelo cético: a primeira é a de que o prazer imediato sempre é importante e, é claro, ganha ainda mais influência se os outros objetos forem diminuídos (por exemplo, por meio de uma reflexão sobre a insignificância da vida humana). A segunda é que comparações entre a nossa própria situação e a dos outros exerce sobre nós uma grande influência e, se percebermos que muitos estão em situação pior que a nossa, podemos tirar daí um grande consolo. Mesmo essas duas considerações, porém, são problemáticas, já que a primeira tende a mortificar nossas paixões e a segunda, a fazer com que homens de boa natureza se sintam mal, já que podem ser acometidos por um grau doloroso de compaixão. O cético, então, termina por recusar, de maneira geral, a filosofia, ainda que depois de reflexões mais extensas sobre ela do que as que haviam sido realizadas pelo epicurista.

Tudo isso dito, podemos observar que essas quatro “escolas” são apresentadas como que por meio de representantes que falam a uma grande audiência. Em notas de rodapé ao longo desses ensaios, Hume apresenta, em certos momentos, posições em que discorda desses homens que nos falam ${ }^{229}$. No próprio ensaio sobre o cético, vemos uma

\footnotetext{
${ }^{229}$ Nesse aspecto, podemos endossar tranquilamente a interpretação de Lívia Guimarães segundo a qual as falas presentes nesses ensaios permanecem o tempo todo isoladas dos ouvintes. Não há espaço para diálogo ou para perguntas; nenhum argumento pode ser acrescentado ou retirado. Os representantes das quatro “escolas” em questão são colocados na condição de pregadores e, evidentemente, parecem todos
} 
nota em que nosso autor apresenta algumas outras reflexões filosóficas que lhe parecem apropriadas e que o cético não admite. Além disso, a não ser que toda a interpretação que desenvolvemos ao longo deste trabalho for completamente inviável, não é possível atribuir a Hume simplesmente uma completa recusa da filosofia, ainda que essa realmente pareça uma alternativa válida em certo ponto da “dialética” que observamos na “Conclusão” do Livro 1 do Tratado. Finalmente, nosso autor realmente afirma que a melhor vida possível é aquela em que estão combinados o aspecto social, o ativo e o contemplativo. O epicurista pode não estar certo ao desmerecer completamente a filosofia, mas certamente tem razão ao valorizar os amigos, a boa mesa e a amada. O estoico parece tolo ao se colocar em um templo que estaria acima de qualquer patamar que possa ser atingido pelos outros mortais, mas sua descrição da benevolência está em pleno acordo com aquela que vemos na Seção 2 da Investigação sobre os princípios da moral e que, de acordo com alguns comentadores, passou a ser, para Hume, o próprio fundamento da moralidade. O elogio das artes feito pelo estoico também nos parece, em linhas gerais, legitimamente humiano. O platônico, por sua vez, teria o assentimento de nosso autor ao afirmar que a filosofia exige grande dedicação, mas não ao colocá-la como uma forma de saber que deve contemplar grandes mistérios que dizem respeito à divindade. Ao fim e ao cabo, parece que o cético do ensaio, caricatural como os outros três filósofos, é apresentado como partidário de apenas mais uma escola. Sua valorização não apenas do prazer, mas de toda a vida comum, o coloca em uma situação mais vantajosa que a do Epicurista, mas ele é apresentado como alguém que vê toda filosofia como um conjunto de preceitos prontos que revelam um caminho para a felicidade que é, na melhor das hipóteses, bastante duvidoso. Podemos dizer que Hume tenderia a concordar com isso, ao menos parcialmente. Ocorre, porém, que ele haveria descoberto que é possível filosofar de modo a levar em conta a dinâmica do mundo e a não perder de vista as posições do homem comum, mas sem dar a elas um assentimento irrestrito, destituído de qualquer visão crítica. Assim, não nos parece inadequado afirmar que a filosofia humiana é, de algum modo, uma tentativa de superar o

igualmente dogmáticos. No fim, parece que o cético se aproxima mais das posições de Hume, ou ao menos do modo como ele procede, mas não há uma concordância completa entre Hume e o cético caricatural descrito no ensaio. É interessante notar, além disso, que Hume nos põe no lugar da audiência, mas, seja pelo tom adotado no texto, seja por notas de rodapé, transforma a audiência não em grupo que simplesmente receberá os ensinamentos das escolas para, em seguida, escolher entre eles, mas em uma instância verdadeiramente crítica. Cf. GUIMARÃES 24, pp. 183-4. 
diagnóstico do cético por meio de uma superação de toda uma forma de se pensar $a$ própria filosofia. Sim, se quisermos ser filósofos, devemos continuar a ser homens, mas isso não pode, para Hume, significar que devemos, para ser homens, deixar de ser filósofos.

Vimos que o quarteto de ensaios acerca dos quais tecemos essas breves considerações é introduzido como uma série de apresentações de filosofias que "surgem naturalmente" e que "dizem respeito à vida humana e à felicidade”. Parece natural, então, que a vida e a felicidade são os temas a partir dos quais se engendra a própria atividade filosófica. Podemos, nesse contexto, entender a afirmação feita por Hume na carta a Hutcheson não como uma recusa dessas questões, mas como uma recusa a um tratamento teleológico delas. O problema, então, não é para que é feito o homem, mas quais os meios para que ele possa alcançar uma forma de vida que ele mesmo coloca para si como fim. E nesse sentido, a filosofia certamente era vista por nosso autor como uma ferramenta poderosa. Ao decidir conciliar as duas espécies de filosofia, era natural que ele passasse a ver seus escritos como uma forma de arte. Se a filosofia humiana é, em certo aspecto, filosofia fácil, ela deve ser capaz de convencer seu leitor por um apelo a seus sentimentos e, nesse sentido, ela se constitui também como obra literária. O recurso constante a exemplos históricos, cotidianos e literários, portanto, torna-se um modo de "pintar" para o leitor, com o máximo de vivacidade, os modos pelos quais ele deve raciocinar e os cursos de ação que ele deve adotar. Nesse sentido, a filosofia pode funcionar do mesmo modo que a poesia, a eloqüência, a música ou a pintura, as quais, como vemos em "Of the Delicacy of Taste and Passion", colaboram para "uma certa

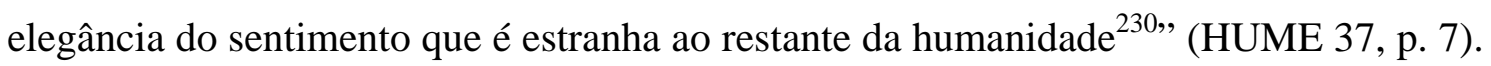
A correção do raciocínio, a ampliação da experiência e o aumento da sensibilidade para as paixões humanitárias e para o belo, portanto, certamente fazem parte daquilo que a filosofia deve buscar oferecer. E esse "refinamento" certamente é visto por Hume como algo favorável à nossa felicidade, pois colabora para o desenvolvimento das paixões mais agradáveis e constantes, tornando-nos menos suscetíveis à melancolia que afeta as pessoas excessivamente sensíveis quando elas se vêem em maus momentos, ao mesmo tempo em que nos dispõe a escolher amigos e livros que possam não apenas

\footnotetext{
230 “[...] a certain elegance of sentiment to which the rest of mankind are strangers”.
} 
corresponder às expectativas dadas pelo próprio gosto refinado, mas, também, colaborar para uma expansão maior desse gosto.

Parece, então, que Hume, quando se viu capaz de conciliar o pintor e o anatomista, passou a desenvolver uma filosofia que fosse proveitosa ao homem comum tanto no sentido de torná-lo mais sensato quanto mais virtuoso e mais feliz. Parece, aliás, que esses três aspectos passaram a ser vistos por nosso autor como indissociáveis. Isso não quer dizer, é claro, que a filosofia humiana seja uma tentativa de uma grande reforma social. Ainda que um homem em situação privilegiada seja apresentado, tanto na Investigação sobre os princípios da moral quanto em "The Stoic”, como alguém que, se for benevolente, poderá trazer grandes benefícios para a sociedade, não há uma recomendação de que o filósofo governe ou algo do tipo. Além disso, não há, por parte de nosso autor, uma tentativa de transformar em filósofos os homens comuns, ou não seria preciso, para atingi-los, conciliar as diferentes espécies de filosofia. Em "Of the Middle Station of Life”, Hume não apenas nos oferece uma descrição de certa classe mais propensa à filosofia como também define o tipo de leitor que deseja alcançar. Ele pode não fazer parte de uma “classe média”, mas é certamente um homem para quem é importante tornar-se sensato (talvez como o wise man da Investigação sobre entendimento humano) e virtuoso. Ora, o homem sensato, como já vimos, será levado, ao valorizar a vida social e a ampliar sua experiência por meio da história, da filosofia e das artes, a ser um homem com uma percepção bastante apurada da virtude, à qual certamente terminará por assentir. Sabemos que a percepção da virtude é, para Hume, um sentimento prazeroso. Sabemos, também, que a vida social é, para ele, não apenas prazerosa como também um remédio bastante eficaz contra a melancolia.

Concluímos, então, que a filosofia passou a ser, para Hume, um modo de formar homens que, sensatos e virtuosos, certamente passariam a ser mais felizes. Esse é o aspecto que permeia todos os temas de que tratamos ao longo deste trabalho. A instituição do filósofo como um ser que participa ativamente da vida social e da experiência acessível também ao homem comum certamente foi essencial para que, em certo momento, nosso autor pudesse conciliar as diferentes espécies de filosofia. Apenas por meio de um conhecimento "participativo" é que se torna viável perceber aquilo que efetivamente pode ser objeto de nossos estudos e, mais ainda, de que modo esses tais objetos podem ser empregados em benefício da vida comum. Além disso, é esse mesmo conhecimento pautado pela experiência de que todos participam que permite ao filósofo 
reconhecer os procedimentos que o habilitarão a se comunicar com os leitores "não profissionais”. Desse modo, a filosofia humiana, em sua versão mais acabada, se apresenta como uma verdadeira tentativa de construir um instrumento de formação, na medida em que ela pretende interferir de modo direto nas crenças e, consequentemente, nos sentimentos daqueles que se dispõem a dar a ela uma chance e, evidentemente, Hume não considera que isso seria possível se o filósofo fosse um eremita que, sem ter qualquer vivência do mundo, pretende, ainda assim, dizer aos outros homens o que devem fazer para ser felizes. É preciso, isso sim, que, com base em elementos que podem ser reconhecidos por todos, o filósofo explique a seu público os princípios que descobriu e que consiga, a partir disso, mostrar com desenvoltura de que modo a própria explicação se torna, ela própria, uma recomendação bastante persuasiva.

Não podemos deixar de observar que, quando lemos a filosofia humiana dessa maneira, a epistemologia desenvolvida por ele, ainda que não deixe de ser importante, torna-se algo diferente de uma ferramenta metodológica ou de uma simples descrição do modo como deveríamos raciocinar. Ainda que não deixe de ser nenhuma dessas coisas, a teoria do conhecimento se transforma, nas mãos de um filósofo como Hume, em um chave para que possamos nos livrar da superstição e, também, para que possamos estabelecer quais são os fatores que interferem tanto em nossas vidas particulares quanto no bem público. Isso leva a crer que, talvez sendo vista por nosso autor não exatamente como o ponto principal de sua filosofia, a teoria do conhecimento que durante tanto tempo atraiu a maior parte da atenção dos comentadores era considerada por Hume como parte de um processo que deveria levar a uma filosofia moral que, sem a menor dúvida, passou a ser, nas obras posteriores ao Tratado, formação moral ${ }^{231}$. Conciliar as diferentes espécies de filosofia é, portanto, transformar a atividade filosófica em algo voltado para a promoção da felicidade humana de modo muito mais direto do que aquele do anatomista que deve se limitar a auxiliar o pintor.

Desse modo, ainda que nosso autor não pretenda que a filosofia seja responsável por grandes mudanças sociais (ainda que possa explicá-las, prevê-las e, em alguns

\footnotetext{
${ }^{231}$ Isso não quer dizer necessariamente que, como afirmou Norman Kemp Smith, Hume tenha escrito em primeiro lugar o Livro 3 do Tratado para, em seguida, passar aos outros, que deveriam simplesmente embasá-lo. Ainda assim, não podemos negar que, em uma leitura como a que fizemos aqui, Hume certamente não está sendo meramente retórico ao afirmar, no início da Seção 1 da Parte 1 do mesmo Livro 3, que a moral é um assunto que nos interessa mais que qualquer outro.
} 
casos, indicá-las), certamente passou, em dado momento, a acreditar que ela poderia trazer benefícios não apenas para aqueles que se tornam filósofos, mas também para aqueles que os lêem. Pode haver nisso certa justiça poética, ainda que quase certamente não intencional: ao conciliar as diferentes espécies de filosofia, Hume provavelmente percebeu que poderia prestar ao homem comum um serviço bastante valioso e, como vimos, foi a convivência promovida pela natureza que permitiu a nosso filósofo escapar de uma melancolia que o havia atirado ao mais profundo desespero. É claro que os amigos com quem filósofos jogam gamão podem ser, ocasionalmente, também eles filósofos. Ainda assim, no momento em que se dá o próprio convívio social, são todos homens comuns e, se esses momentos são, às vezes, propícios a discussões filosóficas, é apenas porque, se não fosse assim, esses homens perderiam algo no âmbito do prazer. 


\section{BibliografiA}

1. AYER, A. J., Hume: A Very Short Introduction. Oxford; New York: Oxford University Press, 1979.

2. BAIER, ANNETTE, A Progress of Sentiments: Reflections on Hume's Treatise. Cambridge: Harvard University Press, 1991.

3. BAIER, ANNETTE, Death and Character: Further Reflections on Hume. Cambridge: Harvard University Press, 2008.

4. BAIER, ANNETTE, “Hume on Women's Complexion”, in Jones, Peter (org.), The Science of Man in the Scottish Enlightenment. Edimburgh: Edimburgh University Press, 1989.

5. BAIER, ANNETTE, "Why Hume Asked Us Not To Read The Treatise”, in BAIER, ANNETTE, Death and Character: Further Reflections on Hume. Cambridge: Harvard University Press, 2008.

6. BAILLIE, JAMES, Routledge Philosophy Guidebook to Hume on Morality. New York : Routledge, 2000.

7. BLACKBURN, SIMON, Reading Hume on Human Understanding. London: Granta Publications, 2008.

8. BOLZANI FILHO, ROBERTO, “Ceticismo e Empirismo”, in SMITH, PLÍNIO JUNQUEIRA e SILVA FILHO, WALDOMIRO, Ensaios sobre o ceticismo. São Paulo: Alameda Casa Editorial, 2007.

9. BUTLER, JOSEPH, “Quinze Sermões”, in CABRAL, ÁLVARO (org.), Filosofia moral britânica: textos do século XVIII - Volume 1. Campinas: Editora da UNICAMP, 1996.

10. BRICKE, JOHN, Mind and Morality: An Examination of Hume's Moral Psychology. Oxford; New York: Oxford University Press, 2000.

11. BROADIE, ALEXANDER, The Cambridge Companion to the Scottish Enlightenment. Cambridge: Cambridge University Press, 2003. 
12. CABRAL, ÁLVARO (org.), Filosofia moral britânica: textos do século XVIII Volume 1. Campinas: Editora da UNICAMP, 1996.

13. CAPALDI, NICHOLAS, Hume's Place in Moral Philosophy. New York: Peter Lang Publishing, 1992.

14. CHAPPELL, V. C., Hume: A Collection of Critical Essays. Notre Dame: Notre Dame University Press, 1968.

15. CHIRPAZ, FRANÇOIS, Hume et le procès de la metaphysique. Paris: Beauchesne, 1989.

16. CHISICK, HARVEY, "David Hume and the Common People”, in Jones, Peter (org.), The Science of Man in the Scottish Enlightenment. Edimburgh: Edimburgh University Press, 1989.

17. CLÉRO, JEAN-PIERRE, Hume. Paris: Vrin, 1998.

18. DELEUZE, GILLES, Empirismo e Subjetividade. Trad. Luiz B. L. Orlandi. São Paulo: Editora 34, 2001.

19. DESCARTES, RENÉ, "Discurso do Método”, in RAMOS, VITOR (org.), DESCARTES, RENÉ, Obra Escolhida. São Paulo: Difusão Européia do Livro, 1962.

20. DESCARTES, RENÉ, “Meditações de Filosofia Primeira”, in RAMOS, VITOR (org.), DESCARTES, RENÉ, Obra Escolhida. São Paulo: Difusão Européia do Livro, 1962.

21. FLEW, ANTHONY, Hume's Philosophy of Belief: A Study of his First Enquiry. New York; London: Routledge \& Kegan Paul, 1966.

22. FOGELIN, ROBERT J., Hume's Skepticism in the Treatise of Human Nature. London: Routledge \& Kegan Paul, 1985.

23. GARRETT, DON, Cognition and Commitment in Hume's Philosophy. Oxford; New York: Oxford University Press, 1997. 
24. GUIMARÃES, LÍVIA, “A Melancholy Skeptic”, Kriterion 108, vol. XLIV pp.180-190. Belo Horizonte: Departamento de Filosofia da Faculdade de Filosofia e Ciências Humanas da UFMG, 2003.

25. GUIMARÃES, LÍVIA (org.), Ensaios Sobre Hume. Belo Horizonte: Editora Segrac, 2005.

26. GUIMARÃES, LÍVIA, “Hume’s Natural History of Religion”, in Guimarães, Lívia (org.), Ensaios Sobre Hume. Belo Horizonte: Editora Segrac, 2005.

27. HERDT, JENNIFER A., Religion and Faction in Hume's Moral Philosophy. Cambridge: Cambridge University Press, 1997.

28. HOBBES, THOMAS, Leviathan. London: Penguin Books, 1982.

29. HUME, DAVID, A Letter from a Gentleman to his Friend in Edimburgh. Ed. James Fieser. Disponível em http://infomotions.com/etexts/philosophy/17001799/hume-letter-741.htm

30. HUME, DAVID, A Treatise of Human Nature. Eds. L. A. Selby-Bigge e P. H. Nidditch. Oxford; New York: Oxford University Press, 1978.

31. HUME, DAVID, A Treatise of Human Nature. Eds. David Fate Norton e Mary J. Norton. Oxford; New York: Oxford University Press, 2000.

32. HUME, DAVID, An Enquiry Concerning Human Understanding. Ed. Tom L. Beauchamp. Oxford; New York: Oxford University Press, 1999.

33. HUME, DAVID, An Enquiry Concerning The Principles of Morals. Ed. Tom L. Beauchamp. Oxford; New York: Oxford University Press, 1998.

34. HUME, DAVID, Dialogues concerning Natural Religion. Ed. Norman Kemp Smith. New Jersey, Prentice Hall, 1947.

35. HUME, DAVID, Disertación sobre las pasiones y otros ensayos morales (ed. bilingue espanhol-inglês). Trad. José Luis Tasset Carmona. Barcelona: Anthropos, 1990. 
36. HUME, DAVID, Enquiries Concerning Human Understanding and Concerning the Principles of Morals. Eds. L. A. Selby-Bigge e P. H. Nidditch. Oxford: Oxford University Press, 1975.

37. HUME, DAVID, Essays Moral, Political and Literary. Ed. Eugene F. Miller. Indianapolis, Liberty Fund, 1985.

38. HUME, DAVID, The Letters of David Hume. Oxford: Clarendon Press, 1932.

39. HUME, DAVID, The Natural History of Religion and Dialogues concerning Natural Religion. Eds. A. Wayne Colver e John Valdimir Price. Oxford: Clarendon Press, 1976.

40. HUME, DAVID, The History of England. Indianapolis: Liberty Fund, 1983.

41. HUME, DAVID, Past Masters - Hume. InteLex Corporation, 1993.

42. HUTCHESON, FRANCIS, An Essay on the Nature and Conduct of the Passions and Affections, with Illustrations on the Moral Sense, Edited and with an Introduction by Aaron Garrett. Indianapolis: Liberty Fund, 2002.

43. HUTCHESON, FRANCIS, An Inquiry into the Original of Our Ideas of Beauty and Virtue, Edited and with an Introduction by Wolfgang Leidhold. Indianapolis: Liberty Fund, 2004.

44. JAFFRO, LAURENT, “As várias maneiras filosóficas de recorrer ao senso comum nas Luzes britânicas” (trad. Pedro Paulo Pimenta), Discurso 33 pp. 3574. São Paulo: Departamento de Filosofia da FFLCH - USP, 2003.

45. JONES, PETER, Hume's Sentiments: Their Ciceronian and French Context. Edimburgh: Edimburgh University Press, 1982.

46. JONES, PETER (org.), The Science of Man in the Scottish Enlightenment. Edimburgh: Edimburgh University Press, 1989.

47. KEMP SMITH, NORMAN, The Philosophy of David Hume - With a new introduction by Don Garret. New York: Palgrave Macmillan, 2005.

48. LE JALLÉ, ÉLÉONORE, Hume et la régulation morale. Paris, PUF, 1999. 
49. LEBRUN, GÉRARD, “A boutade de Charing-Cross”, in RIBEIRO DE MOURA, CARLOS ALBERTO, CACCIOLA, MARIA LÚCIA M. O. e KAWANO, MARTA (orgs), LEBRUN, GÉRARD, A filosofia e sua história. São Paulo, Cosac Naify, 2006.

50. LEROY, ANDRÉ LOUIS, David Hume. Paris: PUF, 1953.

51. LIMONGI, MARIA ISABEL, "Sociabilidade e Moralidade: Hume leitor de Mandeville”, Kriterion, Revista de Filosofia 108, vol. XLIV pp. 224-43. Belo Horizonte: Departamento de Filosofia da Faculdade de Filosofia e Ciências Humanas, 2003.

52. LIVINGSTON, DONALD, "Hume on the Natural History of Philosophical Consciousness”, in Jones, Peter (org.), The Science of Man in the Scottish Enlightenment. Edimburgh: Edimburgh University Press, 1989.

53. LIVINGSTON, DONALD, Philosophical Melancholy and Delirium: Hume's Pathology of Philosophy. Chicago: The University of Chicago Press, 1998.

54. LOCKE, JOHN, An Essay Concerning Human Understanding. London: Penguin Books, 1997.

55. MACKIE, JOHN LESLIE, Hume's Moral Theory. London: Routledge \$ Kegan Paul, 1980.

56. MALHERBE, MICHEL, La philosophie empiriste de David Hume. Paris, Vrin, 2001.

57. MANDEVILLE, BERNARD, The Fable of the Bees, Or Private Vices, Publick Benefits, With a Commentary Critical, Historical and Explanatory by F. B. Kaye. Indianapolis: Liberty Fund, 1988.

58. MERLEAU-PONTY, MAURICE, Conversas - 1948. São Paulo: Martins Fontes, 2004.

59. MICHAUD, YVES, Hume et la fin de la philosophie. Paris: PUF, 1983.

60. MILLICAN, PETER, Reading Hume on Human Understanding. Oxford: Oxford University Press, 2002. 
61. MONTEIRO, JOÃO PAULO, “Associação e Crença Causal em David Hume”, in MONTEIRO, JOÃO PAULO, Novos Estudos Humeanos. São Paulo: Discurso Editorial, 2003.

62. MONTEIRO, JOÃO PAULO, Hume e a Epistemologia. São Paulo: Discurso Editorial, 2009.

63. MONTEIRO, JOÃO PAULO, Novos Estudos Humeanos. São Paulo: Discurso Editorial, 2003.

64. MONTEIRO, JOÃO PAULO, Teoria, Retórica, Ideologia. São Paulo: Editora Ática, 1975.

65. MOSSNER, ERNEST CAMPBELL, The Life of David Hume. Oxford: Clarendon Press, 2001.

66. MOURA, CARLOS ALBERTO R., Racionalidade e Crise. São Paulo: Discurso Editorial,/Curitiba: Editora UFPR, 2002.

67. NORTON, DAVID FATE, Hume: Common Sense Moralist, Sceptical Metaphysician. Princeton: Princeton University Press, 1984.

68. NORTON, DAVID FATE (org.), The Cambridge Companion to Hume. Cambridge: Cambridge University Press, 1980.

69. NOXON, JAMES, Hume's Philosophical Development. Oxford: Oxford University Press, 1973.

70. O’CONNOR, DAVID, Routledge Philosophy Guidebook to Hume on Religion. New York: Routledge, 2001.

71. OWEN, DAVID, Hume’s Reason. Oxford: Oxford University Press, 1999.

72. PASSMORE, JOHN A., Hume’s Intentions. London: Duckworth, 1980.

73. PENELHUM, TERENCE, David Hume: An Introduction to his Philosophical System. West Lafayette: Purdue University Press, 1992.

74. PENELHUM, TERENCE, Hume. New York: Macmillan, 1975. 
75. PEREIRA, OSWALDO PORCHAT, “Ainda é preciso ser cético”, Discurso 32 pp. 9-30. São Paulo: Departamento de Filosofia da FFLCH - USP, 2001.

76. PEREIRA, OSWALDO PORCHAT, Vida comum e ceticismo. São Paulo: Brasiliense, 1993.

77. POPKIN, RICHARD H., The High Road to Pyrrhonism. Indianapolis: Hackett, 1993.

78. POPKIN, RICHARD H., The History of Scepticism from Erasmus to Spinoza. Berkeley: University of California Press, 1979.

79. POPPER, KARL, A Lógica da Pesquisa Científica, trad. Leonidas Hegenberg e Octanny Silveira da Mota. São Paulo: Cultrix, 1972.

80. POTKAY, ADAM, The Fate of Eloquence in the Age of Hume. Ithaca: Cornell University Press, 1994.

81. POTKAY, ADAM, The Passion for Happiness: Samuel Johnson and David Hume. Ithaca: Cornell University Press, 2000.

82. PRICE, JOHN VALDIMIR, The Ironic Hume. Austin: University of Texas Press, 1965.

83. RAMOS, VITOR (org.), DESCARTES, RENÉ, Obra Escolhida. São Paulo: Difusão Européia do Livro, 1962.

84. READ, RUPERT e RICHMAN, KENNETH A. (orgs), The New Hume Debate Revised Edition. New York: Routledge, 2007.

85. RIBEIRO DE MOURA, CARLOS ALBERTO, CACCIOLA, MARIA LÚCIA M. O. e KAWANO, MARTA (orgs), LEBRUN, GÉRARD, A filosofia e sua história. São Paulo, Cosac Naify, 2006.

86. SALTEL, PHILIPPE, Hume. Paris: Ellipses, 2000.

87. SEXTUS EMPIRICUS, Outlines of Scepticism, translated by Julia Annas and Jonathan Barnes. Cambridge: Cambridge University Press, 1994. 
88. SHAFTESBURY, ANTHONY ASHLEY COOPER, THIRD EARL OF, Characteristics of Men, Manners, Opinions, Times, Ed. KLEIN, LAWRENCE E. Oxford: Oxford University Press, 1999.

89. SMITH, PLÍNIO JUNQUEIRA, O Ceticismo de Hume. São Paulo: Edições Loyola, 1995.

90. SMITH, PLÍNIO JUNQUEIRA e SILVA FILHO, WALDOMIRO, Ensaios sobre o ceticismo. São Paulo: Alameda Casa Editorial, 2007.

91. STRAWSON, GALEN, "David Hume: Objects and Power", in READ, RUPERT e RICHMAN, KENNETH A. (orgs), The New Hume Debate Revised Edition. New York: Routledge, 2007.

92. STRAWSON, PETER FREDERICK, Ceticismo e Naturalismo.

93. STROUD, BARRY, Hume. New York: Routledge, 1981.

94. WINKLER, KENNETH P., “The New Hume”, in READ, RUPERT e RICHMAN, KENNETH A. (orgs), The New Hume Debate - Revised Edition. New York: Routledge, 2007.

95. WRIGHT, JOHN P., “Hume’s causal realism: recovering a traditional interpretation”, in READ, RUPERT e RICHMAN, KENNETH A. (orgs), The New Hume Debate - Revised Edition. New York: Routledge, 2007. 